\title{
Evaluation of FRP composite panels manufactured by high temperature VARIM process
}

\author{
Manab Medhi \\ West Virginia University
}

Follow this and additional works at: https://researchrepository.wvu.edu/etd

\section{Recommended Citation}

Medhi, Manab, "Evaluation of FRP composite panels manufactured by high temperature VARIM process" (2008). Graduate Theses, Dissertations, and Problem Reports. 1980.

https://researchrepository.wvu.edu/etd/1980

This Thesis is protected by copyright and/or related rights. It has been brought to you by the The Research Repository @ WVU with permission from the rights-holder(s). You are free to use this Thesis in any way that is permitted by the copyright and related rights legislation that applies to your use. For other uses you must obtain permission from the rights-holder(s) directly, unless additional rights are indicated by a Creative Commons license in the record and/ or on the work itself. This Thesis has been accepted for inclusion in WVU Graduate Theses, Dissertations, and Problem Reports collection by an authorized administrator of The Research Repository @ WVU. For more information, please contact researchrepository@mail.wvu.edu. 


\title{
Evaluation of FRP Composite Panels Manufactured by High Temperature VARIM
} Process

\author{
Manab Medhi \\ Thesis submitted to the \\ College of Engineering and Mineral Resources \\ at West Virginia University \\ In partial fulfillment of the requirements \\ for the degree of \\ Master of Science \\ in \\ Civil Engineering
}

\author{
Hota V.S. GangaRao, Ph.D., Chair \\ P.V. Vijay, Ph.D., Co-chair \\ Ruifeng Liang, Ph.D.
}

\section{Department of Civil Engineering}

\section{Morgantown, West Virginia 2008}

Keywords: Glass, fiber reinforced polymers, composites, resin infusion, cardboard tubes, tension, bending, SEM

Copyright 2008 Manab Medhi 


\section{ABSTRACT \\ Evaluation of FRP Composite Panels Manufactured by High Temperature VARIM Process}

\section{Manab Medhi}

Design and manufacturing of fiber reinforced polymer (FRP) composite panels using high temperature vacuum assisted resin infusion molding (HT-VARIM) and evaluation of their mechanical properties were carried out through this research effort. The two major process parameters, temperature and percentage of catalyst mixed with resin, were optimized to obtain superior quality composites through in-situ curing under vacuum pressure of 13 to 14 psi.

Initially, composite specimens with glass fabrics and vinyl ester resin were manufactured with $1.5 \%$ and $2 \%$ catalyst by weight and cured at four different curing temperatures: room temperature, $120^{\circ} \mathrm{F}, 150^{\circ} \mathrm{F}$, and $200^{\circ} \mathrm{F}$. The specimens were preliminarily tested under four point bending loads and examined under scanning electron microscope (SEM). HT-VARIM manufactured composites having vinyl ester resin with $1.5 \%$ catalyst and cured at $150^{\circ} \mathrm{F}$ temperatures provided the highest bending modulus, ultimate stress and lower percentage of air voids. Both design and manufacturing procedure of cellular FRP pavement panels with required fiber/fabric configuration were thus formalized based on data obtained from laboratory manufactured specimens. Later, test specimens and panels were manufactured at coupon and component level by HT-VARIM during different phases of this research. Finally, prototype FRP pavement panels were manufactured by Fiber-tech Inc. for field installation by West Virginia Department of Highways (WVDOH). These pavement panels are scheduled for field installation in early spring 2009 near Morgantown, West Virginia.

Tension, bending and short beam shear tests were conducted on coupon specimens cut from the HT-VARIM panels made in phases I and II, and also under mass-production schemes. Panels were tested under three point bending loads (corresponding to HS25 truck loading) and fatigue (3 Hz frequency) loading. Panel layout and connection drawings for field installation are provided in Appendix A. In addition, glass fabric based lightweight honeycomb panels were also manufactured by VARIM process and results of the tests carried out on those specimens are presented in Appendix B. A 3D stitching technique (provisional patent number: 60/918,398), developed as a part of this research work is provided in Appendix $\mathrm{C}$ including recommendations for further improvements in panel production process. Theoretical panel stiffness evaluations are provided in Appendix D. 


\section{ACKNOWLEDGEMENTS}

I extend my sincere gratitude to Dr. Hota GangaRao for his guidance throughout the course of this research work. I express sincere thanks to Dr. Vijay for his guidance, without which it would have been difficult to carry out this research work. I would like to thank Dr. Liang for his guidance while conducting this research. I will ever remain grateful to Mr. Jerry Nestor without whom I would not have been able to finish this work. I wish to thank my other lab mates Vamsi Talikonda, Saurabh Batra, Doug Cutlip, Asif Mohammad and engineering scientist Mark Skidmore. Last, but not the least, I express my heartiest thanks to Vimala Shekar for providing me the motivation during this research work. I also express my sincere gratitude to WVDOT-DOH, USA for financing supporting this research work.

Last but not the least, I would like to express my heartiest thanks to my sister Mimi Roy and brother Sriroop Chaudhuri for being with me during the tough times of my life. 


\section{TABLE OF CONTENTS}

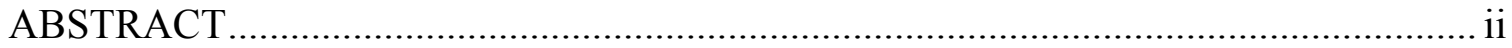

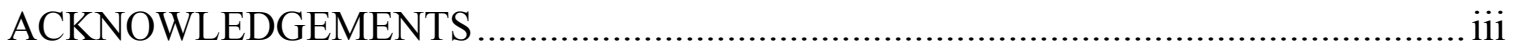

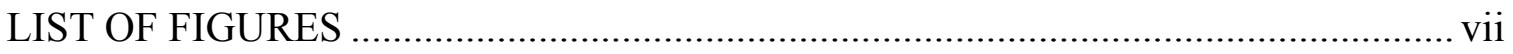

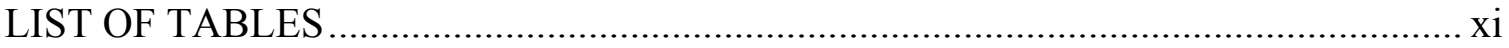

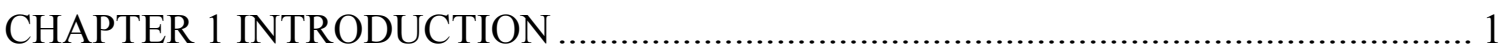

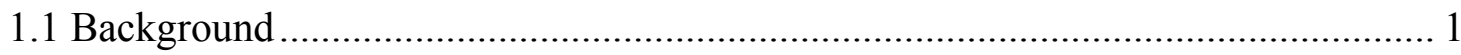

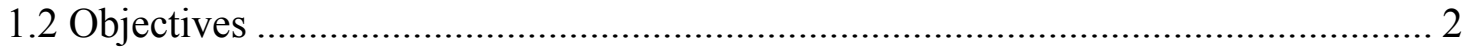

1.3 Scope

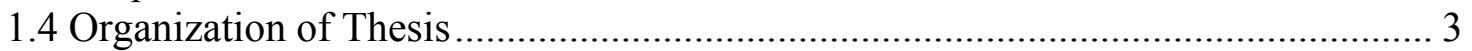

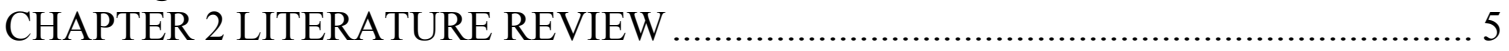

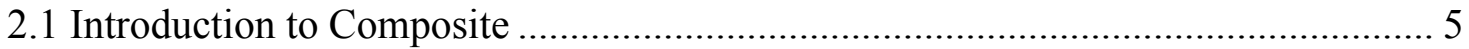

2.1.1 Glass Fiber Reinforced Polymer Composite................................................... 6

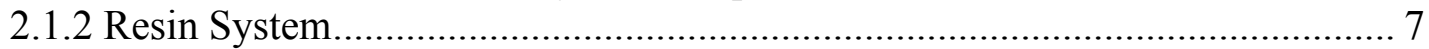

2.2 Manufacturing Processes of Composite................................................................... 7

2.3 Prodeck- 4 by Constructed Facilities Center, WVU ................................................ 8

CHAPTER 3 MATERIAL AND MANUFACTURING PROCESS................................. 13

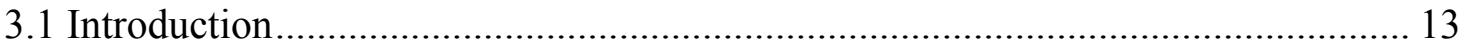

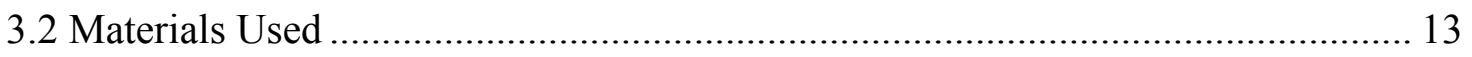

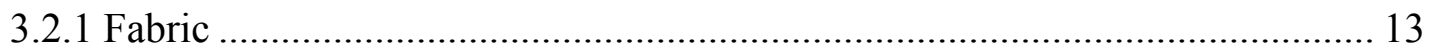

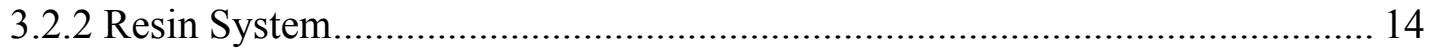

3.3 Manufacturing of Coupon Test Plates ............................................................. 18

CHAPTER 4 LABORATORY TESTING DETAILS.................................................. 29

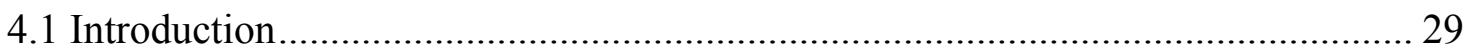

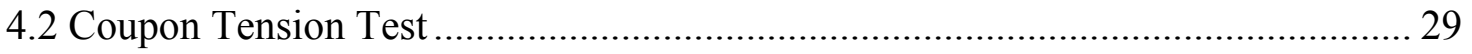

4.2.1 Specimen Preparation .......................................................................... 29

4.2.2 Test Set-up and Test Procedure ................................................................... 30

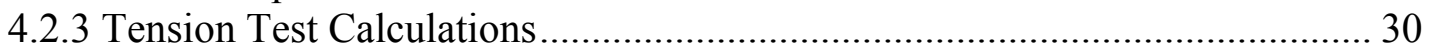

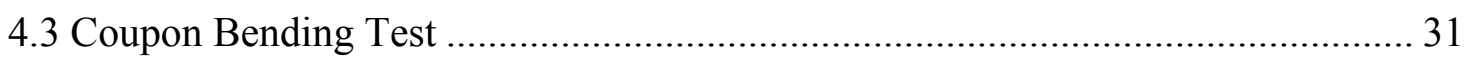

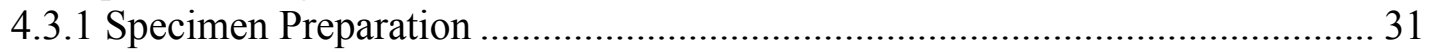

4.3.2 Test Set-up and Test Procedure ………………….......................................... 31

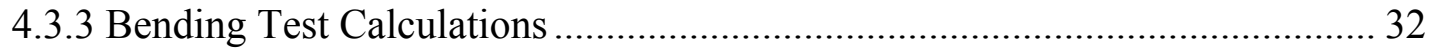

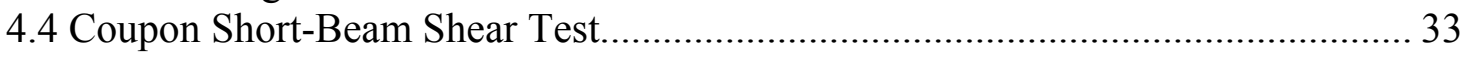

4.4.1 Test Specimen Preparation ............................................................................. 33

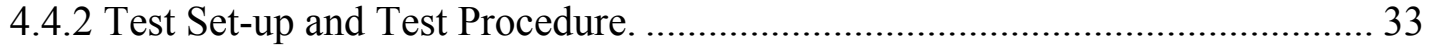

4.4.3 Short Beam Shear Test Calculation ............................................................ 34

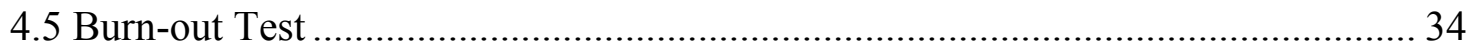


4.5.1 Burn out Test Specimens ………………………............................................. 34

4.5.2 Test Procedure and Set Up.......................................................................... 35

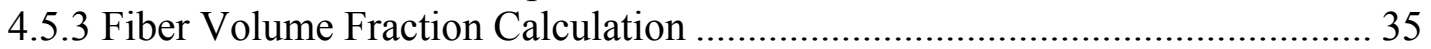

4.6 Three Point Bending Test of Panel ..................................................................... 35

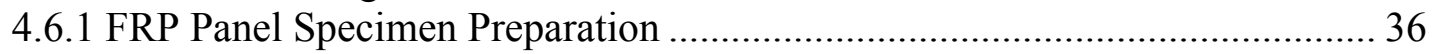

4.6.2 FRP Panel Test Set-up and Procedure ……………....................................... 36

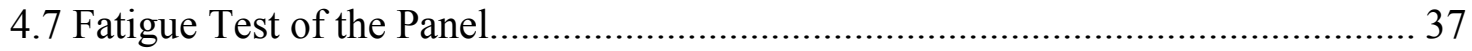

4.7.1 Specimen Preparation ................................................................................. 37

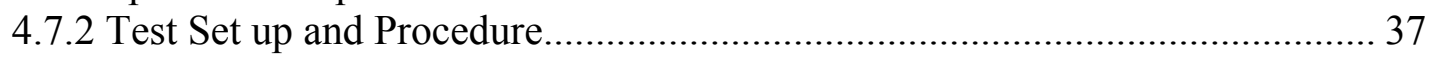

4.8 Scanning Electron Microscopy ………………................................................. 38

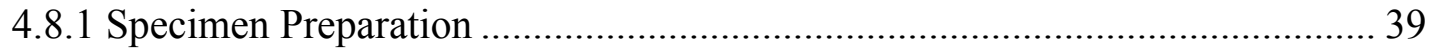

4.8.2 Test Set up and Test Procedure.................................................................... 40

CHAPTER 5 EXPERIMENTAL RESULTS ………............................................... 41

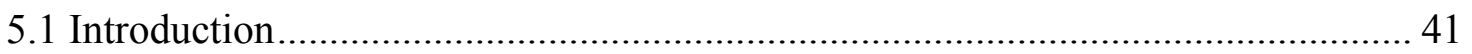

5.2 Optimization of Process Parameters of HT-VARIM ............................................. 42

5.2.1 Curing Time of Vinyl Ester Resin for Varying Catalyst Percentage................ 42

5.2.2 Tests on Coupon Specimens ............................................................................ 43

5.2.2.1 Bending Test Results and Discussions of Coupon Specimens .................. 43

5.2.3 SEM Pictures and Interpretations .................................................................. 49

5.3 Experimental Results of Panels Manufactured by Fiber-Tech Inc........................ 52

5.3.1 Phase I Test Panels.................................................................................... 52

5.3.1.1 Burn out Test and Discussion ................................................................. 53

5.3.1.2 Tension Test Results of Coupons ……………......................................... 53

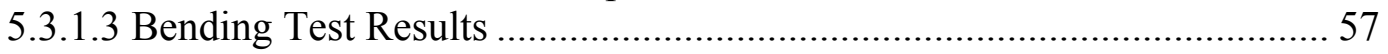

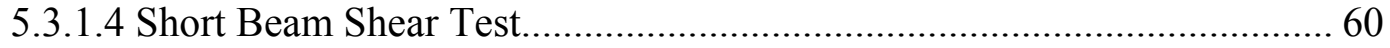

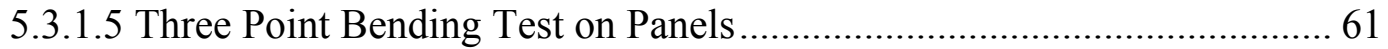

5.3.1.6 SEM Pictures of Specimens Cut from Panel ............................................. 63

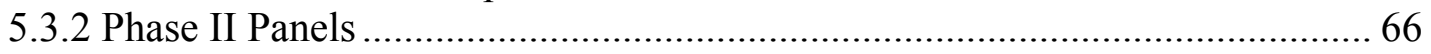

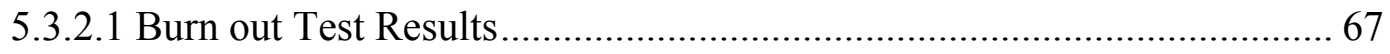

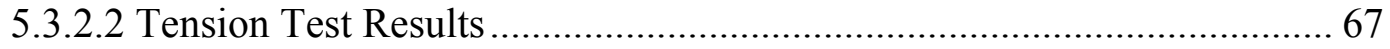

5.3.2.3 Bending Test Results of Coupons.......................................................... 71

5.3.2.4 Short Beam Shear Test............................................................................ 73

5.3.2.5 Three Point (Patch Load) Bending Test of Panel ..................................... 74

5.3.3 Test Panel Produced During Mass Production of the Actual Panel.................. 84

5.3.3.1 Burn out Test Results of Coupons ............................................................. 84

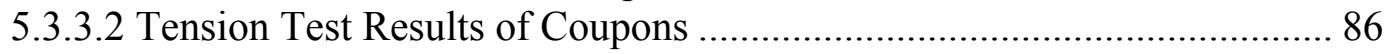

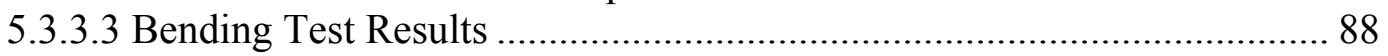

5.3.3.4 Short Beam Shear Test......................................................................... 90

5.3.3.5 Three Point Bending Test of Test Panel Produced Through Mass

Production Process ......................................................................................... 90

5.3.3.6 Patch Loading with Two Feet Span .......................................................... 93

5.3.4 Properties of Full Size Panels Manufactured and to be Installed in Field....... 98

CHAPTER 6 CONCLUSIONS AND RECOMMENDATIONS …………................... 106

6.1 Summary and Conclusions: ................................................................................. 106

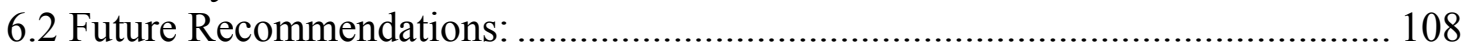




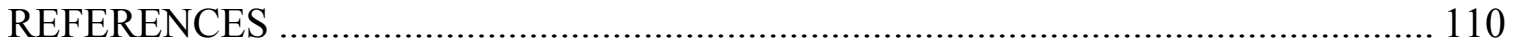

APPENDIX A INSTALLATION OF PAVEMENTS................................................ 112

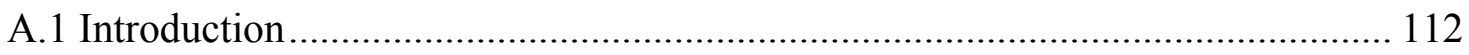

A.2 Panel Layout and Connections.................................................................... 113

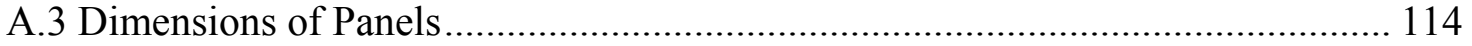

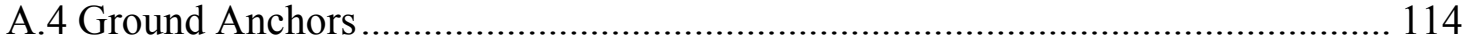

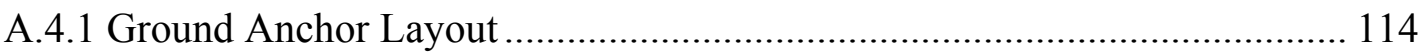

A.4.2 Ground Anchor Types........................................................................... 115

APPENDIX B LIGHTWEIGHT HONEYCOMB PANEL ........................................ 118

APPENDIX C RECOMMENDED 3-D STITCHING TECHNIQUE FOR PANELS... 123

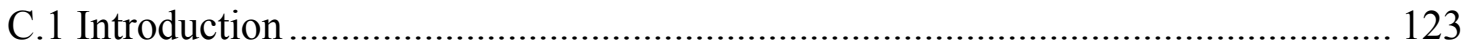

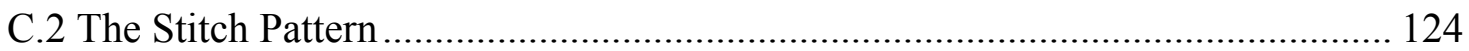

APPENDIX D CLASSICAL LAMINAR PLATE THEORY AND ACTUAL

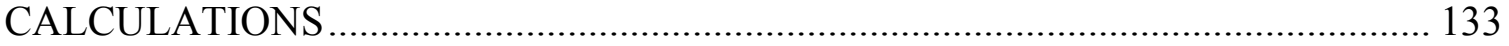

D.1 Classical Laminar Plate Theory (CLPT) for Design............................................ 133

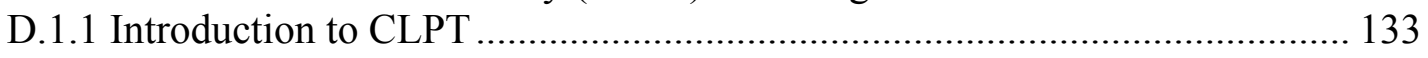

D.1.2 Computation of Bending (EI) and Shear Rigidities (GA)............................ 133

D.1.3 Actual Calculation Done for our Panel System ............................................. 136 


\section{LIST OF FIGURES}

Figure 2.1 Schematic representations of reinforcement, matrix and interface ................... 5

Figure 2.2 Cross sectional dimensions of Prodeck 4 (Desai, 2007) ................................ 10

Figure 2.3 Fabric architecture of Prodeck 4 (Desai, 2007)............................................ 10

Figure 3.1 Chemical structure of (a) Vinyl Ester (b) Cobalt Naphthenate (c) MEKP...... 17

Figure 3.2 Distribution of fibers in the flanges along four directions, phase I panels

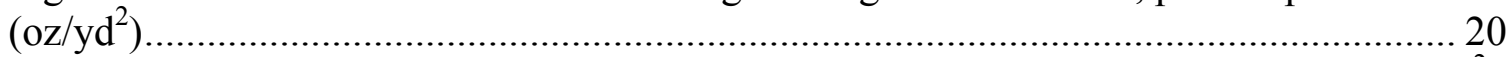

Figure 3.3 Distribution of fibers in the webs along four directions, phase I panels ( $\left.\mathrm{oz} / \mathrm{yd}^{2}\right)$

Figure 3.4 Distribution of fibers in the flanges along four directions, phase II panels $\left(\mathrm{oz} / \mathrm{yd}^{2}\right)$ 21

Figure 3.5 Distribution of fibers in the webs along four directions, phase II panels $\left(\mathrm{oz} / \mathrm{yd}^{2}\right)$.

Figure 3.6 Distribution of fibers in the flanges along four directions, test panel produced during mass production $\left(\mathrm{oz} / \mathrm{yd}^{2}\right)$ 22

Figure 3.7 Distribution of fibers in the webs along four directions, test panel produced during mass production $\left(\mathrm{oz} / \mathrm{yd}^{2}\right)$..... 22

Figure 3.8 Distribution of fibers in the flanges along four directions, actual panels produced during mass production $\left(\mathrm{oz} / \mathrm{yd}^{2}\right)$ 23

Figure 3.9 Distribution of fibers in the webs along four directions, actual panels produced during mass production $\left(\mathrm{oz} / \mathrm{yd}^{2}\right)$. 23

Figure 3.10 Distribution of fibers in the flange along four directions of Prodeck 4 produced by Pultrusion $\left(\mathrm{oz} / \mathrm{yd}^{2}\right)$ 24

Figure 3.11 Distribution of fibers in the webs along four directions of Prodeck 4

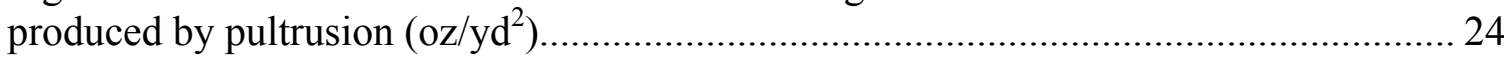

Figure 3.12 FRP panel ( $13 \mathrm{ft} \times 8 \mathrm{ft} 10 \mathrm{inch}$ ) being moved to the testing bay.................. 25

Figure 3.13 Resin accumulations at the bottom surface ............................................... 26

Figure 3.14 Stacked FRP pavement panels ready for installation ................................... 27

Figure 3.15 Mass produced FRP pavement panels at the WVDOH storage yard ............ 27

Figure 4.1 Strain gage on tension test specimens …………....................................... 30

Figure 4.2 Baldwin machine used for tension test....................................................... 30

Figure 4.3 Strain gage on bending test specimens .................................................... 31

Figure 4.4 Instron machine used for coupon bending test .............................................. 32

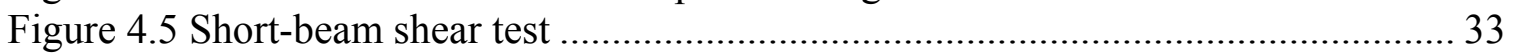

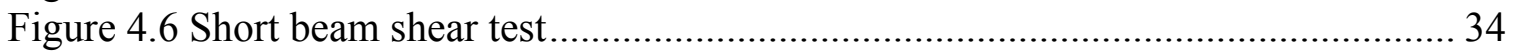

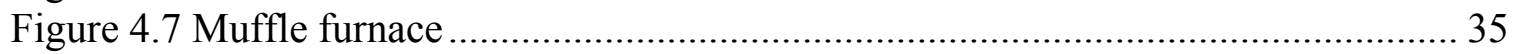

Figure 4.8 Dimensions and strain gage location of the test panel .................................... 36

Figure 4.9 Test set up for three point bending test of panel ............................................. 37

Figure 4.10 Panel placed over the gravel under fatigue load........................................ 38

Figure 4.11 Hitachi S-4700 field emission scanning electron microscope (FE-SEM)

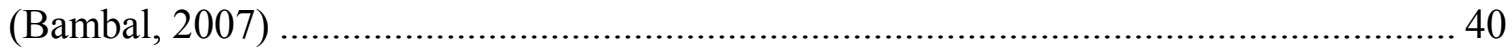

Figure 5.1 Variation of curing time of VER with the change of MEKP (\%) .................. 43 
Figure 5.2 Load-deflection of specimens cured at $150^{\circ} \mathrm{F}$ with $1.5 \%$ catalyst and $200^{\circ} \mathrm{F}$ and $2 \%$ weight catalyst

Figure 5.3 Variation of normalized stress for different cure temperature and varying MEKP

Figure 5.4 Average bending modulus variation for different cure temperature and varying

MEKP 48

Figure 5.5 Maximum bending stress variation for different cure temperatures and \% catalyst (MEKP). 48

Figure 5.6 Predominant air pockets for specimens cured at room temperature $\left(\sim 93^{0} \mathrm{~F}\right)$

with $1.5 \%$ and $2 \%$ catalyst.....

Figure 5.7 Reduction in air pocket for specimens cured at $120^{\circ} \mathrm{F}$ (Vs. room temperature)

Figure 5.8 Fiber orientation of specimens cured at $150^{\circ} \mathrm{F}$............................................ 50

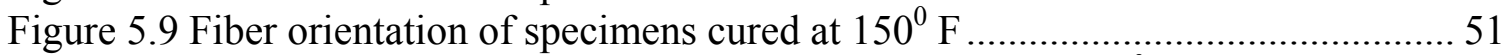

Figure 5.10 Fiber dryness at some places in specimens cured at $200^{\circ} \mathrm{F}$ with $1.5 \%$ catalyst

Figure 5.11 Fiber dryness at some places in specimens cured at $200^{\circ} \mathrm{F}$ and $2 \%$ by weight

Figure 5.12 Stress Vs strain curve for specimen number $\mathrm{TF}_{1} \mathrm{P}$

Figure 5.13 Typical picture showing misalignment of zero degree fibers ...................... 56

Figure 5.14 Cardboard attached on tensile specimens:................................................ 57

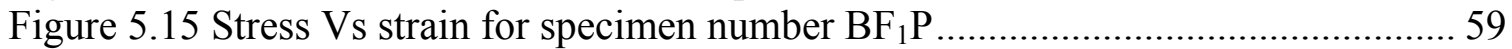

Figure 5.16 Load Vs deflection for specimen number $\mathrm{BF}_{1} \mathrm{P}$........................................ 59

Figure 5.17 Bending moment diagram for three point bending test................................ 61

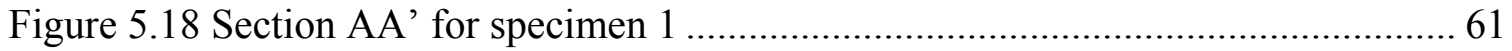

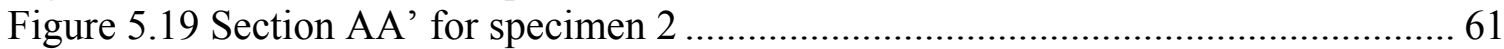

Figure 5.20 Stress Vs strain for panel (specimen 1) under three point bending ................ 62

Figure 5.21 Load Vs deflection for panel (specimen 2) under three point bending ......... 62

Figure 5.22 45/-45 and zero degree fibers at the web.................................................... 64

Figure 5.23 Uniform resin infusion in the web area ..................................................... 64

Figure 5.24 Uniformity of resin infusion in the flange area ............................................6 65

Figure 5.25 Good resin infusion and fiber wet-out at the web-flange junction................. 65

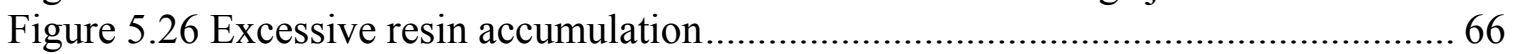

Figure 5.27 Stress Vs strain for tensile specimens from web, top and bottom flanges ... 70

Figure 5.28 Stress Vs strain curve of specimens cut from web, top and bottom flange of

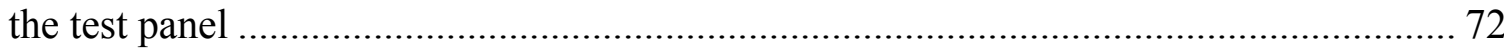

Figure 5.29 Stress Vs strain curve of specimens cut from web, top and bottom flange... 73

Figure 5.30 Different panel orientations, surface and patch load configurations ............. 75

Figure 5.31 Tensile stress at bottom flange Vs strain for type I loading ……….............. 77

Figure 5.32 Load Vs deflection for type I loading......................................................... 77

Figure 5.33 Tensile stress at bottom flange Vs strain for type II loading......................... 78

Figure 5.34 Load Vs deflection for type II loading ...................................................... 78

Figure 5.35 Tensile stress at bottom flange Vs strain for type III loading ...................... 79

Figure 5.36 Load Vs deflection for Type III loading..................................................... 79

Figure 5.37 Tensile stress at bottom flange Vs strain for type IV loading ....................... 80

Figure 5.38 Load Vs deflection for type IV loading..................................................... 80 
Figure 5.39 Top and bottom flange strains of FRP panel over a gravel base, under $23 \mathrm{klbs}$ static loads

Figure 5.40 Young's moduli of the panel (calculated from load-deflection curve)

subjected to fatigue 83

Figure 5.41 Compression of panel cells under 23 kips static load, measured after ' $N$ '

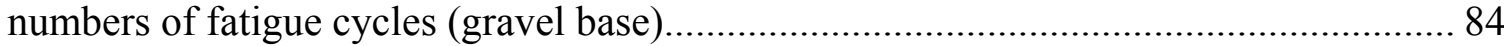

Figure 5.42 Stress-strain of specimens from web, top and bottom flange.

Figure 5.43 Stress-strain of specimen from web, top and bottom flange, under four point

bending 89

Figure 5.44 Variation of strain $\mathrm{Vs}$ ' $\mathrm{N}$ ' fatigue cycles.................................................. 92

Figure 5.45 Deflection profile of the panel under static load with a gravel base ............ 93

Figure 5.46 Cross section of the test panel ................................................................ 94

Figure 5.47 Field condition showing a pavement panel without partial subbase support 94

Figure 5.48 Panel was tested with $2 \mathrm{ft}$ span under 10 inch x 20 inch patch loading ........ 95

Figure 5.49 Strain gage at the interior web attached after cutting a 2 inches $\mathrm{x} 2$ inches

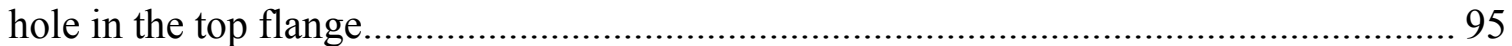

Figure 5.50 Strain at top and bottom flange of the panel after 1 and 2 million fatigue

cycles.

Figure 5.51 Strains at center of exterior and interior webs under static load (after 1

million fatigue cycles).

Figure 5.52 Schematic top view (not to the scale) of Case I loading condition of the panel with dial gage locations 98

Figure 5.53 Schematic top view (not to the scale) of Case II loading condition of the panel with dial gage locations.

Figure 5.54 Stress-strain at the bottom of the panel along the span for Case I and Case II

loading...

Figure 5.55 Load Vs deflection (at center) of the panel under Case I and Case II types loading...

Figure 5.56 Stress Vs strain at the bottom flange in transverse and longitudinal directions under Case II Loading....

Figure 5.57 Stress Vs strain at top and bottom flanges in transverse directions under Case

II loading 101

Figure 5.58 Resin accumulation and fiber/fabric at some webs .................................. 102

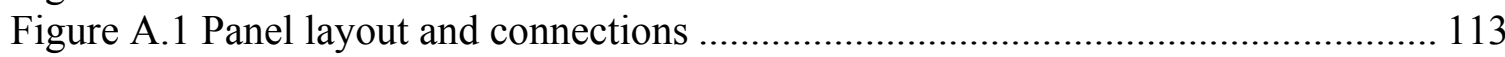

Figure A.2 Pavement panels with anchor holes......................................................... 114

Figure A.3 Testing set up for the ground anchors .................................................... 115

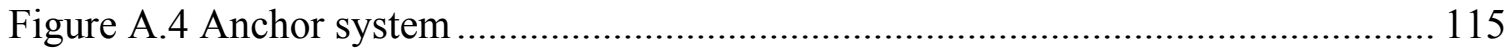

Figure A.5 Grouting of the anchor hole................................................................... 116

Figure A.6 Circular or rectangular card-boards (left) or flexible tubes (right).............. 117

Figure B.1 Polyurethane honeycomb Core .............................................................. 118

Figure B.2 Bending test of type I honeycomb panel .................................................. 119

Figure B.3 Bending test of type II panel............................................................... 120

Figure B.4 Bending test of type III panel just before putting the patch.......................... 120

Figure B.5 Load Vs deflection Curve of type II panel ................................................ 121

Figure B.6 Load Vs deflection Curve of type III panel ................................................ 122

Figure B.7 Failure pattern of the honeycomb panel ................................................... 122 
Figure C.1 Multi-cellular shape developed in the CFC research laboratory, at WVU ... 125

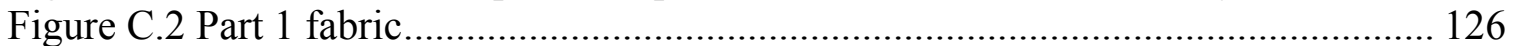

Figure C.3 The webs (part 1) of two adjacent cells ..................................................... 127

Figure C.4 After all webs (part 1) of all the cells are stitched to each other. ................. 128

Figure C.5 Stitched cells are then rotated 180 degrees from position in figure 4 . The top

flange (part 2) is then stitched with the top face of each cell .................................... 128

Figure C.6 The top flange (part 2) is stitched to the top face of each cell and then rotated

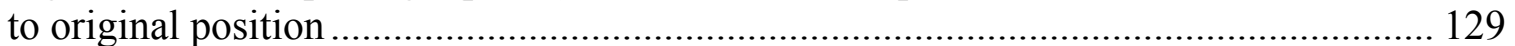

Figure C.7 The bottom flange (part 3) is stitched to the bottom face of each cell. ....... 129

Figure C.8 Multi-cellular shape developed in the research laboratory, CFC, WVU..... 130

Figure C.9 The fabrics are marked at $0.5^{\prime}$ ' spacing to fix the stitching locations .......... 130

Figure C.10 The part 1 (web) integrated with part 1(web) by stitching ....................... 131

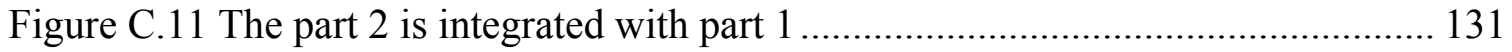

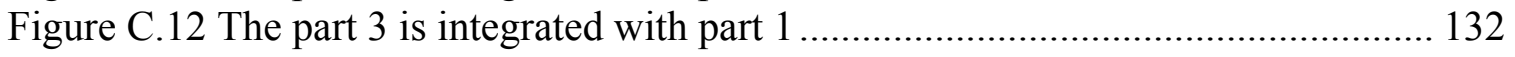

Figure D.1 Load Vs deflection curve shown as sample calculation ............................ 139 


\section{LIST OF TABLES}

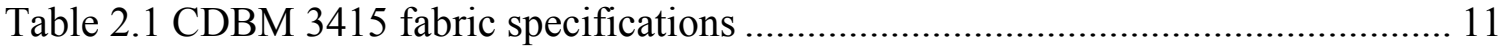

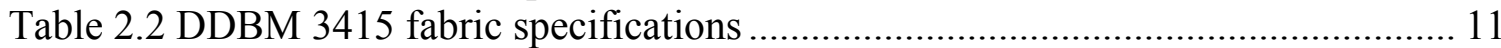

Table 2.3 Equivalent fabric to be placed at the face carpet (top or bottom):.................... 12

Table 2.4 Equivalent fabric to be wrapped around the cardboard ................................. 12

Tables 3.1 Properties of glass fabric used in this study ................................................ 13

Table 3.2 Data sheet for vinyl ester resin 510A (source: Dow Chemical Co. brochure) . 15

Table 3.3 Fabric architectures of panels produced during different phases of the project 19

Table 5.1 Variation of curing time of VER with the change of MEKP (\%).................... 42

Table 5.2 Bending test specimen dimension and manufacturing details:......................... 44

Table 5.3 Bending test Results................................................................................... 45

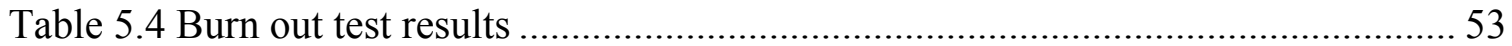

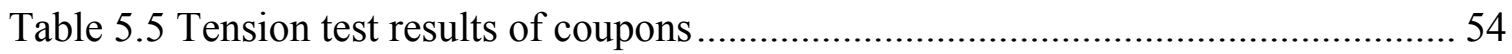

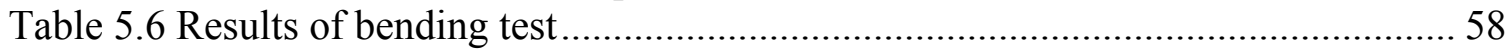

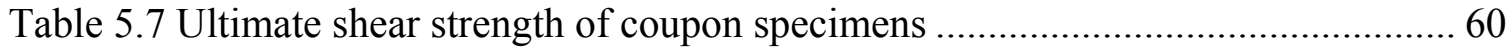

Table 5.8 Experimental results of the three point bending test...........................................63

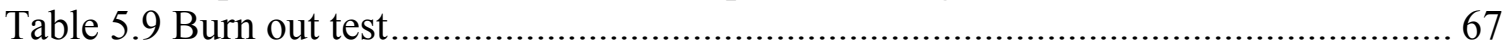

Table 5.10 Tension test results of coupon specimens ...................................................... 69

Table 5.11 Four point bending test results of coupons .................................................... 71

Table 5.12 Short Beam Shear test results …………….............................................. 73

Table 5.13 Three point (patch load) bending test results of panel................................... 76

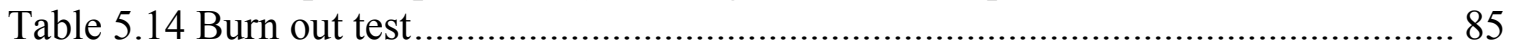

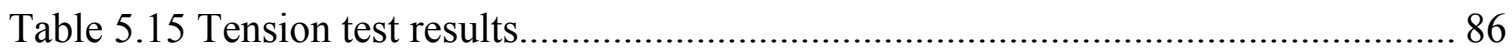

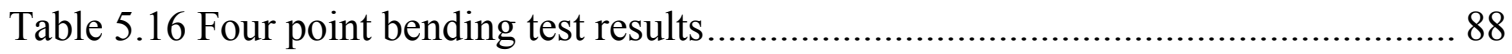

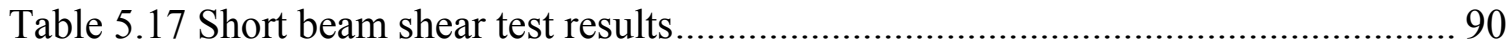

Table 5.18 Three point bending test results of panel................................................... 91

Table 5.19 Results of the bending test conducted on the actual panel ........................... 99

Table 5.20 Summary of mechanical properties of panels at coupon and component levels

Table A.1 Specification supplied by "The ground anchor"......................................... 116

Table B.1 Details of thee types of specimens prepared................................................. 118

Table B.2 Bending test results of type I honeycomb panel ............................................ 119

Table B.3 Bending test results of type II and III honeycomb panel .............................. 121 


\section{CHAPTER 1 INTRODUCTION}

\subsection{Background}

The application of fiber reinforced polymer (FRP) composite materials has been advancing at a rapid pace since 1980s and has been implemented more frequently in aerospace, automotive, electronics, and construction fields. High strength and stiffness with low self-weight, design flexibility, non corrosiveness and non magnetic response are some of the advantages of FRP composites over conventional materials such as steel and concrete. However, high volume implementation of FRP materials in structural engineering industry as a replacement for conventional steel and concrete still requires tremendous research and development efforts.

The FRP composites have limited application so far in structural engineering field because of material costs, manufacturing difficulties, and lack of structural design and construction specifications. The Federal Highway Administration (FHWA) estimates that the federal government alone has invested over \$1 trillion in the nation's highway system (Wu, 2005). However, 40\% of the Nation's bridges are structurally or functionally deficient $(\mathrm{Wu}, 2005)$. Because of this need, FHWA is stressing the use of asset management systems that will target the most economical allocation of resources in upgrading the Nation's transportation system. Technical challenges associated with aging structures include: time dependent materials degradation, widespread fatigue damage from increased usage, poor selection of materials at design stage or initial flaws in design and/or fabrication. Industry/government/university collaboration can produce new materials and technologies that can extend the service life of constructed facilities with reduced maintenance and improved durability (Wu, 2005). For example, applications of advanced composite materials such as glass, aramid or carbon fibers with polymer matrix binders are gaining importance to extend the service life of infrastructure. Industrial facilities often operate in severely corrosive environments where stringent worker safety requirements are essential for structural reliability, fire suppression and electrical isolation.

FRP composites are in limited use currently; however, efforts towards manufacturing

affordability could make their use more encompassing. Compared to aircraft and marine 
components made of FRP composites, civil infrastructure applications deal in high quantities per project with thousands of projects per year in progress. Automation of the manufacturing process, increased production volume, degree of quality control and quality assurance during the manufacturing and installation phase utilizing the typical civil construction work force can reduce total project cost (Felix Wu H., 2005).

This research work is focused on bringing the technology from laboratory (where it is developed) to practicing pavement engineers (where it is implemented). The main objective is to develop a cost effective and lightweight fiber reinforced polymer composite cellular pavement panel system using HT-VARIM. Manufacturing details, different production parameters and techniques used in this study are described in a separate twenty five page report submitted to CFC, WVU. There are several proprietary information and pictures, which are protected from open disclosure.

\subsection{Objectives}

Objectives of this research are to:

- Develop Lightweight FRP Composite Cellular Panel system by High Temperature Vacuum Assisted Resin Infusion Molding (HT-VARIM).

- Optimize the process parameters-Temperature, Pressure, Curing time and amount of catalyst to be added with neat resin in HT-VARIM.

- Evaluate mechanical properties of FRP Composites manufactured by Resin Infusion Process by conducting tests on coupon specimens and full scale components.

- Theoretically compute stiffness of modular panel.

- Filed install FRP cellular panels as a highway pavement structure.

\subsection{Scope}

This research is conducted as a part of CFC-WVU's on going research to mass produce cellular panels by High Temperature Vacuum Assisted Resin Infusion Molding (HTVARIM). Evaluations of mechanical properties are done at both the coupon and component levels.

Scope of this research is limited to: 
- Evaluating bending properties of coupon specimens manufactured by HTVARIM with different curing temperatures and amount of catalyst added to neat vinyl ester resin. Curing temperatures used were room temperature, $120^{\circ} \mathrm{F}, 150^{\circ} \mathrm{F}$, and $200^{\circ} \mathrm{F}$. Amount of catalyst used were $1.5 \%$ and $2 \%$ by weight of resin. Specimens were examined under Scanning Electron Microscope.

- Developing HT-VARIM based manufacturing procedure to produce cellular FRP panels.

- Manufacturing cellular FRP pavement panels in different phases of this research including their mass production by HT-VARIM.

- Preparing coupon specimens from panels for tension, bending, short beam shear tests and evaluating void content under Scanning Electron Microscope.

- Conducting three point patch loading tests on test panels after zero, one and two million fatigue cycles. Fatigue loads were applied on the test panels by supporting the panel over a gravel base.

- Preparing pavement panel layouts and connection drawings were prepared for field installations including anchoring systems.

\subsection{Organization of Thesis}

Chapter 2 provides an overview of different composite materials and manufacturing processes. It also includes a brief description of HT-VARIM. This chapter also explains other potential applications of the cellular panels manufactured through this research by HT-VARIM. A systematic analysis and design procedure of this type of composite panel system based on the theory developed by CFC-WVU (GangaRao, 1999) is also explained in this chapter. 
Chapter 3 discusses the constituent materials and manufacturing process used in this study.

Chapter 4 explains all the laboratory tests, test set up, ASTM test procedures according, and their significance in mechanical characterization of the composite panel system.

Chapter 5 discusses the results of experiments conducted on the specimens at coupon and component levels. This chapter includes the test results and discussions on the mechanical properties of the cellular panel system.

APPENDIX A includes the sequence and pictures of installation of the cellular panels as pavements.

APPENDIX B includes manufacturing and testing details of honeycomb panels manufactured by Vacuum Assisted High Temperature Infusion with Glass Fabric and Vinyl Ester Resin.

APPENDIX C explains a 3-D stitching technique that could be used as a further improvement of the cellular panels manufactured by resin infusion process.

APPENDIX D discusses the classical laminate plate theory and includes the actual design calculation of the FRP panels manufactured by high temperature VARIM. 


\section{CHAPTER 2 LITERATURE REVIEW}

\subsection{Introduction to Composite}

A composite material is a combination of two or more chemically different materials with a distinct interface between them. It has properties and characteristics that are enhanced from its constituent materials though constituent materials maintain separate identities in the composite. (Mallick, 1997). The major constituents of a composite can be broadly classified as reinforcement in the form of fibers or particulates and polymer matrix. The reinforcements are the major load resisting component of a composite. The polymer matrix holds the reinforcements in place, protects the reinforcements from an adverse environmental condition and also acts as a path for stress transfer between fibers. In this research work, GFRP-Glass Fiber Reinforced Polymer Composite is used for developing structural products. As the name implies, glass fibers are used as reinforcements and vinyl ester is used as polymer matrix. The mechanical properties of a composite not only depend on this reinforcement and polymer matrix, but also on the interface between reinforcement and matrix, which plays a critical role in the performance of the composite material. If there is not a strong interfacial bond between the reinforcement and matrix, irrespective of the type of reinforcement/matrix combination, the reinforcements can not effectively strengthen the matrix and hence, composite material can not effectively resist the external load. A schematic representation of reinforcement, matrix and interface in a composite material is shown in Figure 2.1. The interfacial bond strength can be improved by fiber surface treatment (Mallick, 1997), in addition to improving other parameters.

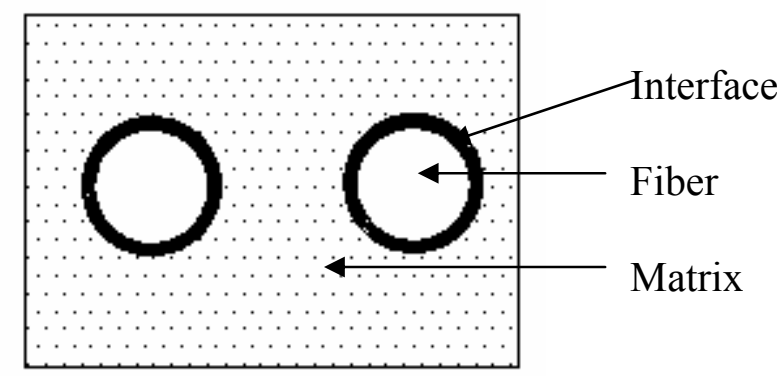

Figure 2.1 Schematic representations of reinforcement, matrix and interface 
Some of the advantages of composite materials are light weight, design flexibility, dimensional stability compared to thermoplastic, high strength etc.

\subsubsection{Glass Fiber Reinforced Polymer Composite}

In fiber reinforced composites, the fibers are the main loading components. Fibers are used in composite because of the following advantages: (a) lightweight (b) stiff and strong (c) fibers are stronger than the bulk material because of the preferential orientation of molecules along the fiber direction and also (d) a fiber contains less number of defects as opposed to the bulk material (Barbero, 1998). Fibers may be continuous or discontinuous like chopped or short fibers. Continuous fibers are preferred in structural application because composite with discontinuous fibers can undergo a large creep deformation. Different types of fibers are available such as glass, carbon, Kevlar (organic), boron, alumina etc. Choosing the type of fiber depends mainly on the following factors: (a) mechanical properties (b) environmental conditions (c) cost of fiber. In our application of FRP composite pavement modulus, we have chosen glass fibers as the reinforcing component because of their: (a) good tensile strength (b) high strength to weight ratio (c) little moisture absorption (d) high Electrical resistance (e) economical feasibility for mass production.

Fibers are available in various forms such as rovings, strands, tow and yarns. Depending on construction and orientations, fiber/fabrics are classified into unidirectional (1D), bidirectional (2D) and even advanced fabrics (3D) including mats. Unidirectional fibers run in one direction $\left(0^{0}\right.$ directions $)$ only, which can be used to mainly resist tensile loads in that (fiber) direction. Mats are of two types: chopped strand mat and continuous strand mat. In case of multidirectional fabrics, multiple layers of continuous rovings are held together by stitching in the plane direction of the fabrics. 2D fabrics are classified into bidirectional (eg., 0/90 . +45/-45 etc.), tri-directional (0/45/-45; 90/+45/-45; etc) and quadridirectional fabrics $(0 / 90 /+45 /-45)$. For our laboratory research, we have used bi-direction $(0 / 90)$ fabric with CSM to produce 12" x 12" plates by HT-VARIM. 


\subsubsection{Resin System}

A variety of commercial resins is available for manufacturing composites. Selection of the suitable resins depend on compatibility with fibers, manufacturing process, and property requirements. Resins are broadly classified as thermosetting and thermoplastic resins.:

1. Thermosetting resins can operate in the temperature range of $125-350^{\circ} \mathrm{C}$. Phenolics, polyesters, polyamide etc are few examples of thermosetting resins.

2. Thermoplastic resins operate in limited temperature range (near ambient). Acrylonitrile-butadiene-styrene (ABS), PVC, polycarbonates, Acrylics, Acetal Copolymers, Acetal Homopolymers etc are few examples of thermoplastic resins.

In all thermoset resin, due to cross linking of polymer molecules, molecular weight increases and resin is finally gelled. Viscosity of resin gradually increases with time (Juska et. al. 1997). Resin can not flow after the gel point is reached. Vinyl ester is a thermoset resin and it was used for the composite manufacturing in this research work. Vinyl esters gel when 5-10\% of the cross-linking has taken place (Juska et. al. 1997).

\subsection{Manufacturing Processes of Composite}

A brief discussion of HT-VARIM is provided in this section. Details of the resin Infusion process used for manufacturing for prototype FRP pavement panels are provided in chapter 3.

In this method, vacuum is applied to penetrate and infuse a dry lay-up of fibers with resin. Resin infusion is a specialized advanced laminating technique that greatly improves the quality and strength of fiberglass parts versus conventional hand lay up. Simultaneous applications of laminate engineering and resin infusion technology allows for optimization of a composite part in terms of strength and weight. During the infusion process, the outer skin of fiber reinforcement fabrics is carefully fitted into the mold over top of the skin coat. The resin was then distributed over the fabric and a peel ply was placed over it. With a vacuum pump, all the air in this "vacuum bag" is sucked out, which compresses or de-bulks the dry stack of reinforcement fabrics. Through a series of feed hoses sealed into the bag, catalyzed resin is sucked by vacuum application from large mixing containers. The vacuum is kept on for desired hours until the resin has cured. 
Since rate of resin curing is increased by application of external heat. The vacuum bag and feed hoses are removed, and the part's lamination is complete. Resin infusion offers numerous benefits and significant strength gains due to the single step method of consolidating and wetting the materials through a vacuum process. The tremendous clamping pressure of the vacuum (approximately 24-30 in $\mathrm{Hg}$ pressure) helps fuse the constituent materials and any air voids are replaced by resin. Due to high quality of this process, and the minimization of potential errors of a laminator, an engineer can afford to specify less material in the structure. In addition, vacuum compression of fiberglass reduces the amount required for wetting/saturation of resin and results in improved strength and weight savings of about $30 \%$ in comparison to traditional cored fiberglass laminate.

\subsection{Prodeck- 4 by Constructed Facilities Center, WVU}

Extensive research have been conducted world wide in order to replace steel or concrete deck/panel system by Fiber Reinforced Polymer (FRP) for its ability to last longer with minimal maintenance cost. Steel reinforcements and structural steel corrode, while concrete cracks due to adverse weather conditions like sulfate attack, freeze-thaw etc. Repair and replacement works of highways and bridges made of structural steel or reinforced concrete is high not only because of material and labor cost, but it is also associated with expenses due to delays and detours (Shehata et. al., 2005). Different types of modular panels manufactured by pultrusion, filament winding etc are available. For example, GFRP plates were adhered to the top and bottom of a number of triangular filament wound tubes bonded with epoxy resin to create one modular unit (Williams et. al., 2003). The deck system of West Mill Bridge in Oxfordshire, is composed of

pultruded GFRP two cell-sections with a triangular cell form, which are adhesively connected to form the deck (Luke et. al., 2002). However, in this research effort, a cost effective and lightweight modular panel system with hollow rectangular cross section was developed by HT-VARIM. The modular panel designed and manufactured in this research work, will primarily be field installed as pavement panels having the future potential of being installed as bridge deck system. 
While deciding and designing the preliminary fiber architecture of the modular pavement panels in this research work, we started with the existing fiber architecture of Prodeck-4 as a design calculation help. Prodeck-4 by CFC, WVU is a multi-cellular, low-profile FRP bridge deck and manufactured using Pultrusion process at Bedford Plastics Inc., PA. It is made of E-glass fiber and Vinyl ester resin through Pultrusion process (Desai, 2007). Figure 2.2 shows the schematic of Prodeck 4 cross section. The deck is 4" high, 29"wide. And thickness of the bottom and top flanges is 0.430 " each while that of the web is 0.375 ". The top and bottom flanges of the bridge deck component are made of 24 layers of $0^{0}$ fibers, $90^{\circ}$ fibers, $\pm 45^{\circ}$ fibers, continuous strand mat (CSM) and 56 Yield Rovings ( 4 per inch). The web is made of 20 layers of $0^{0}$ fibers, $90^{\circ}$ fibers, $\pm 45^{\circ}$ fibers, continuous strand mat (CSM) and 56 Yield Rovings (4 per inch) as shown in Figure 2.3. The fibers continue from top flange to the web and then again to the bottom flange. The low-profile FRP deck has fiber volume fraction of approximately 0.5 and weighs about 10 $\mathrm{lb} / \mathrm{ft}^{2}$.

Dimension and fabric configuration of Prodeck-4 are shown in Figures 2.2 and 2.3 respectively. The material properties of Prodeck 4 obtained from the manufacturer are as follows:

Modulus of elasticity of fiber $(E f)=10.5 \times 10^{6} \mathrm{psi}$

Modulus of elasticity of matrix $(E m)=4.9 \times 10^{5} \mathrm{psi}$

Shear modulus of fiber $(G f)=4.30 \times 10^{6} \mathrm{psi}$

Shear modulus of matrix $(\mathrm{Gm})=1.8 \times 10^{5} \mathrm{psi}$

Poisson's ratio of fiber $(v f)=0.22$

Poisson's ratio of matrix $(\mathrm{vm})=0.38$

Dimensions are shown in Figure 2.2 


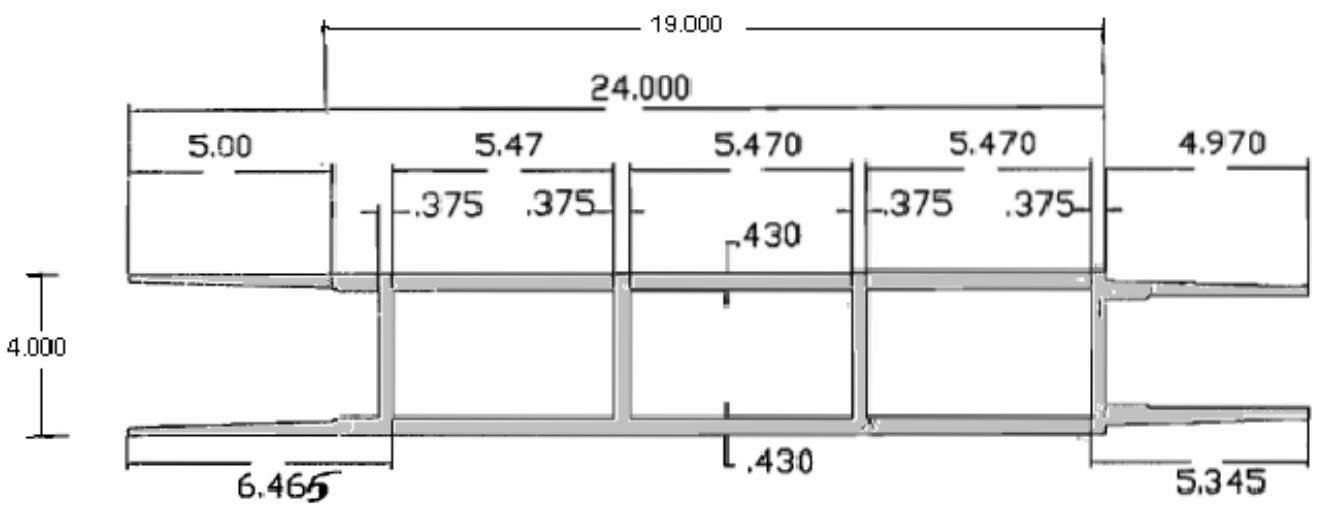

Figure 2.2 Cross sectional dimensions of Prodeck 4 (Desai, 2007)

The fabric architecture is shown in Figure 2.3

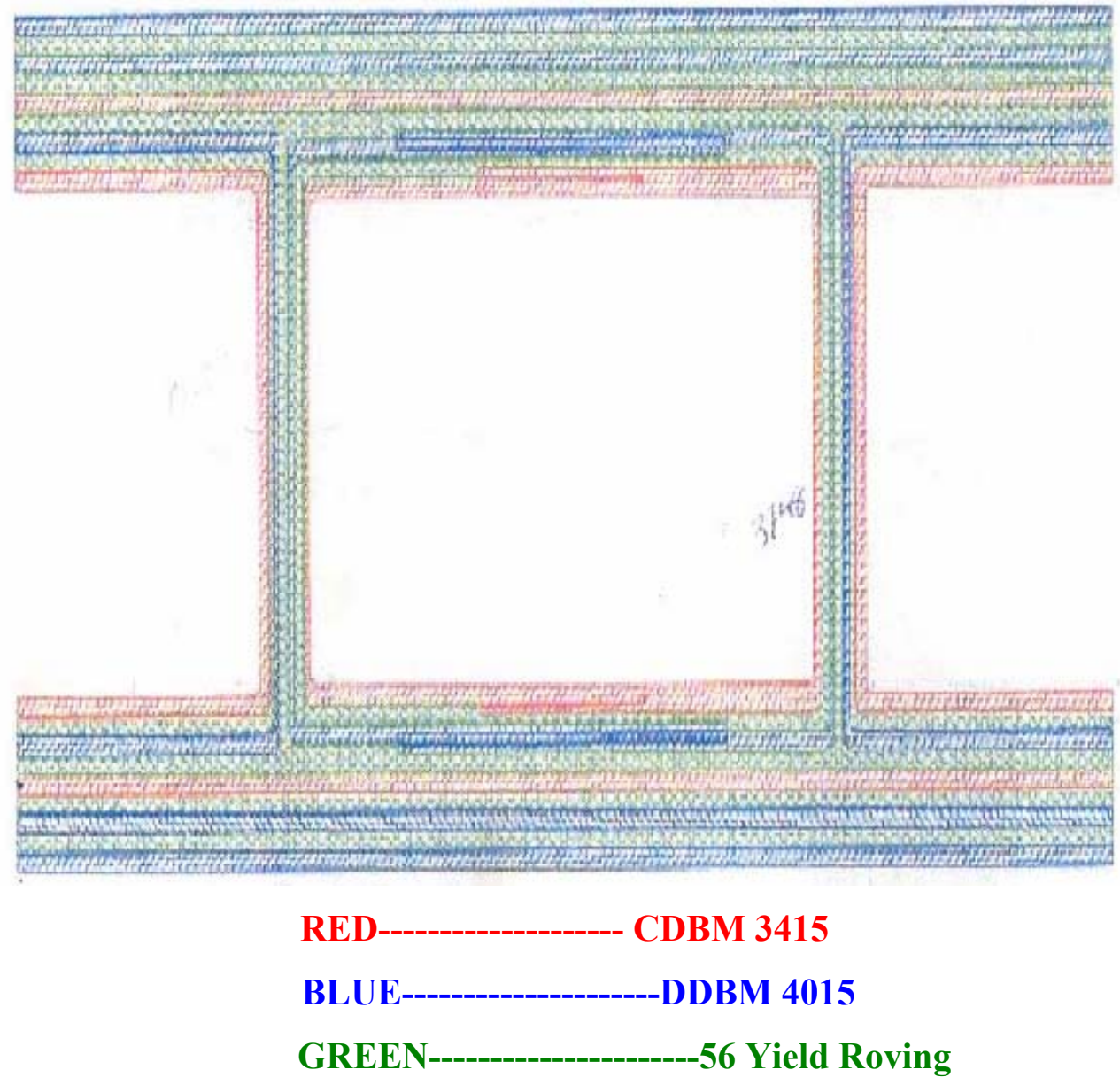

Figure 2.3 Fabric architecture of Prodeck 4 (Desai, 2007) 
The detailed description of CDBM3415 and DDBM4015 fabrics comprising of $0^{\circ}$ fibers, $\pm 45^{\circ}$ fibers and mat (CSM) are given in the Tables 2.1 and 2.2, respectively. The thickness of rovings (Green layer) is calculated to be approximately 0.04 ".

Table 2.1 CDBM 3415 fabric specifications

\begin{tabular}{|c|c|c|c|c|}
\hline $\begin{array}{c}\text { Fiber } \\
\text { Orientation }\end{array}$ & $\begin{array}{l}\text { Nominal Wt. } \\
\left(\mathbf{o z} / \mathbf{y d} \mathbf{d}^{2}\right)\end{array}$ & $\begin{array}{c}\text { Thickness } \\
\text { (in) }\end{array}$ & $\begin{array}{l}W_{f} \\
\text { (lb) }\end{array}$ & $\begin{array}{c}\mathbf{L}_{v} \\
\left(\text { in }^{3}\right)\end{array}$ \\
\hline $0^{0}$ fibers & 15.71 & 0.01610 & 0.109 & 2.31914 \\
\hline$+45^{0}$ fibers & 9.04 & 0.009308 & 0.063 & 1.34042 \\
\hline$-45^{0}$ fibers & 9.04 & 0.009308 & 0.063 & 1.34042 \\
\hline MAT (CSM) & 13.5 & 0.013851 & 0.09375 & 1.99468 \\
\hline Total & 47.29 & 0.048568 & 0.32875 & 6.99466 \\
\hline
\end{tabular}

Table 2.2 DDBM 3415 fabric specifications

\begin{tabular}{|c|c|c|c|c|}
\hline $\begin{array}{c}\text { Fiber } \\
\text { Orientation }\end{array}$ & $\begin{array}{c}\text { Nominal Wt. } \\
\mathbf{( o z}_{\mathbf{0}} \mathbf{y d}^{\mathbf{2}} \mathbf{)}\end{array}$ & $\begin{array}{c}\text { Thickness } \\
\mathbf{( i n )}\end{array}$ & $\begin{array}{c}\mathbf{W}_{\mathbf{f}} \\
\mathbf{( l b )}\end{array}$ & $\begin{array}{c}\mathbf{L}_{\mathbf{v}} \\
\mathbf{( i n}^{\mathbf{3}} \mathbf{)}\end{array}$ \\
\hline $\mathbf{+ 4 5}^{\mathbf{0}}$ fibers & 11.44 & 0.011731 & 0.0794 & 1.68936 \\
\hline $\mathbf{9 0}^{\mathbf{0}}$ fibers & 17.28 & 0.011731 & 0.12 & 2.55319 \\
\hline $\mathbf{- 4 5}^{\mathbf{0}}$ fibers & 11.44 & 0.011731 & 0.0794 & 1.68936 \\
\hline MAT (CSM) & 13.5 & 0.013844 & 0.0937 & 1.99361 \\
\hline Total & 53.66 & 0.055036 & 0.3725 & 7.92552 \\
\hline
\end{tabular}

Where, $\mathbf{W}_{\mathbf{f}}=$ Weight of CSM/fabric per square foot $(\mathrm{lb}.) / \mathrm{ft} 2$

$\mathbf{L}_{\mathbf{v}}=$ Volume of 1'x 1' composite laminate (in.3)

\section{Equivalent fabric architecture of HT-VARIM panels:}

We calculated the equivalent fabric densities in the web and the flange (using fiber/fabric configuration previously developed at CFC-WVU as an initial basis) of the HT-VARIM pavement panels as given in Tables 2.3 and 2.4. 
Table 2.3 Equivalent fabric to be placed at the face carpet (top or bottom):

\begin{tabular}{|c|c|c|c|c|c|}
\hline Fabric Type & $\mathbf{4 5}^{\mathbf{0}}$ & $\mathbf{- 4 5}^{\mathbf{0}}$ & $\mathbf{0}^{\mathbf{0}}$ & $\mathbf{9 0}^{\mathbf{0}}$ & $\mathbf{C S M}$ \\
\hline DDBM & 11.44 & 11.44 & 0 & 17.28 & 13.5 \\
\hline Rovings & 0 & 0 & 40 & 0 & 0 \\
\hline DDBM & 11.44 & 11.44 & 0 & 17.28 & 13.5 \\
\hline Rovings & 0 & 0 & 40 & 0 & 0 \\
\hline CDBM & 9.04 & 9.04 & 15.71 & 0 & 13.5 \\
\hline Rovings & 0 & 0 & 40 & 0 & 0 \\
\hline Total & $\sim 32$ & $\sim 32$ & $\sim 136$ & $\sim 35$ & $\sim 41$ \\
\hline Equivalent to & $\sim 32$ & $\sim 32$ & $\sim 151$ & $\sim 60$ & \\
\hline
\end{tabular}

Table 2.4 Equivalent fabric to be wrapped around the cardboard

\begin{tabular}{|c|c|c|c|c|c|}
\hline Fabric Type & $\mathbf{4 5}^{\mathbf{0}}$ & $\mathbf{- 4 5}^{\mathbf{0}}$ & $\mathbf{0}^{\mathbf{0}}$ & $\mathbf{9 0}^{\mathbf{0}}$ & $\mathbf{C S M}$ \\
\hline CDBM & 9.04 & 9.04 & 15.71 & 0 & 13.5 \\
\hline Rovings & 0 & 0 & 40 & 0 & 0 \\
\hline DDBM & 11.44 & 11.44 & 0 & 17.28 & 13.5 \\
Total & $\sim 20$ & $\sim 20$ & $\sim 56$ & $\sim 17$ & $\sim 27$ \\
Equivalent & $\sim 20$ & $\sim 20$ & $\sim 66$ & $\sim 34$ & \\
\hline
\end{tabular}

Summary: In this chapter, we briefly discussed about the properties of glass fabrics and resin. Also, we mentioned about the pultruded bridge deck system Prodeck 4 developed by the Constructed Facilities Center, WVU. The fiber architecture of Prodeck 4 was used as an initial basis while configuring fiber architecture of pavement panels. In chapter 3, properties of glass fabric, resin systems used for this research effort are provided. The manufacturing set up and test procedure are discussed briefly. Improvements that can be implemented in manufacturing procedure wherever necessary are also provided. Manufacturing details, different production parameters and techniques used in this study are described in a separate twenty five page report submitted to CFC, WVU. There are several proprietary information and pictures, which are protected from open disclosure. 


\section{CHAPTER 3 MATERIAL AND MANUFACTURING PROCESS}

\subsection{Introduction}

This chapter provides an overview on FRP composites, polymer matrix, fiber configuration and their mechanical properties used in this research effort. In addition, HT- VARIM used for manufacturing test plates, test panels and full size FRP pavement panels are described.

\subsection{Materials Used}

This section describes the properties of different glass fabric reinforcement and resin used for manufacturing the FRP pavement panels by HT-VARIM.

\subsubsection{Fabric}

Glass fabric was used in manufacturing coupon specimens and panels by resin infusion process. Different types of glass fabrics used in this research work are shown in Table 3.1 .

Tables 3.1 Properties of glass fabric used in this study

\begin{tabular}{|l|l|l|l|}
\hline \multicolumn{1}{|c|}{ Category } & \multicolumn{1}{|c|}{ Fabric Type } & Orientation (Degree) & \multicolumn{1}{c|}{ Aerial Density } \\
\hline $\begin{array}{l}\text { For Coupon } \\
\text { Manufacturing }\end{array}$ & Bi-axial with CSM & $0 / 90$ and CSM & $\begin{array}{l}0: 5.8 \mathrm{oz} / \mathrm{yd}^{2} \\
90: 6 \mathrm{oz} / \mathrm{yd}^{2} \\
\mathrm{CSM}: 7.6 \mathrm{oz} / \mathrm{yd}^{2}\end{array}$ \\
\hline \multirow{2}{*}{$\begin{array}{l}\text { For Phase I } \\
\begin{array}{l}\text { Production of } \\
\text { Panel }\end{array}\end{array}$} & Uniaxial & 0 & $0: 7.4 \mathrm{oz} / \mathrm{yd}^{2}$ \\
\cline { 2 - 4 } & Quadri-axial & $0 / 90 /+45 /-45$ & $\begin{array}{l}0: 6.5 \mathrm{oz} / \mathrm{yd}^{2} \\
90: 6.5 \mathrm{oz} / \mathrm{yd}^{2} \\
+45: 6.5 \mathrm{oz} / \mathrm{yd}^{2} \\
-45: 6.5 \mathrm{oz} / \mathrm{yd}^{2}\end{array}$ \\
\hline $\begin{array}{l}\text { For Phase II } \\
\text { Production of } \\
\text { Panel }\end{array}$ & Bi-axial I & $0 / 90$ & $\begin{array}{l}0: 9.6 \mathrm{oz} / \mathrm{yd}^{2} \\
90: 6.8 \mathrm{oz} / \mathrm{yd}^{2}\end{array}$ \\
\cline { 2 - 5 } & Bi-axial II & $-45 /+45$ & $\begin{array}{l}45: 8.5 \mathrm{oz} / \mathrm{yd}^{2} \\
-45: 8.5 \mathrm{oz} / \mathrm{yd}^{2}\end{array}$ \\
\hline
\end{tabular}

Note: CSM - Continuous Strand Mat 


\subsubsection{Resin System}

Vinyl ester was used with Methyl Ethyl Ketone Peroxide (MEKP) catalyst for this study. Vinyl ester is a thermosetting resins and have been used widely as polymer matrix for glass fiber composites. A thermoset resin hardens gradually due to polymerization and cross linking of the polymer molecules under pressure and temperature. Vinyl ester resins are stronger and durable than polyester resins and cheaper than epoxy resins. Vinyl ester resins utilize a polyester resin type of cross-linking molecules in the bonding process (Bambal, 2007). Vinyl ester is a hybrid form of polyester resin which has been toughened with epoxy molecules within the main molecular structure. Vinyl ester resins offer better resistance to moisture absorption than polyester resins. On the other hand, vinyl ester is quite sensitive to atmospheric condition and curing temperature. As vinyl ester resin ages, it becomes a different resin (due to its continuous curing as it ages) so new vinyl ester resin sometimes resists bonding to older ones, or will bond and then later peel off. (Bambal, 2007).

DERAKANE 510A-40 Vinyl ester resin was used to make FRP composite pavement panels and laminates by HT-VARIM. DERAKANE 510A-40 (Epoxy) Vinyl Ester Resin is a brominated bisphenol-A based vinyl ester designed to offer maximum degree of fire retardance combined with enhanced chemical resistance and toughness. It offers the highest bromine content of any DERAKANE Resin.

Typical properties of the resin are listed in Table 3.2, as obtained from the manufacturer. MEKP (Methyl Ethyl Ketone Peroxide) is principally used as an initiator or "catalyst" for the room temperature cure of unsaturated polyester and vinyl ester resins. 
Table 3.2 Data sheet for vinyl ester resin 510A (source: Dow Chemical Co. brochure)

\begin{tabular}{|c|c|}
\hline Properties & Values \\
\hline Tensile Strength, $M P a / p s i$ & $85 / 12,300$ \\
\hline Tensile Modulus, GPa/unit $10^{5} \mathrm{psi}$ & $3.4 / 5.0$ \\
\hline Tensile Elongation, $\%$ & 5 \\
\hline Flexural Strength, $M P a / p s i$ & $150 / 21700$ \\
\hline Flexural Modulus, GPa/unit $10^{5} \mathrm{psi}$ & $3.6 / 5.2$ \\
\hline Specific Gravity & 1.34 \\
\hline $\begin{array}{l}\text { Heat Distortion Temperature, }{ }^{\circ} \mathrm{C}\left(F^{\circ}\right) \\
\text { at } 1.82 \mathrm{Mpa}(264 \mathrm{psi}) \text { applied stress }\end{array}$ & $110 / 230$ \\
\hline Barcol Hardness & 40 \\
\hline 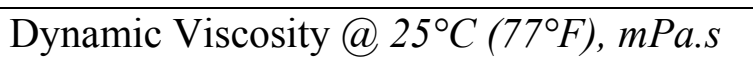 & 400 \\
\hline Styrene Content, $\%$ & 38 \\
\hline 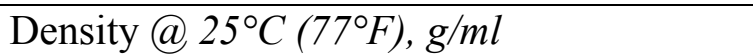 & 1.23 \\
\hline $\begin{array}{l}\text { Commercial Warranty, dark, @ } 25^{\circ} \mathrm{C} \\
\left(77^{\circ} \mathrm{F}\right) \text {, months }\end{array}$ & 4 \\
\hline
\end{tabular}

Vinyl ester resin is preferred over other thermosetting resins because of its excellent thermal and mechanical properties, easy handling/processing at room temperature with mechanical properties similar to epoxy resin, offering better chemical resistance and greater control over cure rate and reaction conditions (Vadlamani, et. al., 2007), good weatherability, ductility and resistance to harsh environments. Vinyl ester can be cured at room or elevated temperature. Elevated temperature of curing is chosen by composite manufacturers to increase the production rate, ease of processing and to achieve economic benefits. This research work focuses on combining the elevated temperature curing along with optimized quantity of Methylethylketone peroxide (MEKP) catalyst and time of heating in HT-VARIM to give quicker and better degree of curing to maximize strength and stiffness properties of composite products.

Research has been done on post curing temperature and time effects on mechanical properties of E-glass/Vinyl Ester composites (Jason et, al., 2006). In the research 
conducted by Jason et. al., 2006, specimens were fabricated at ambient temperature and allowed to sit overnight after fabrication and prior to demolding. The following morning, panels were cut into definite dimensions and post cured at ambient and elevated temperature for different number of days. Results suggested that the degree of conversion is limited to $80 \%$ for the vinyl-ester oligomer following a post cure of $93^{\circ} \mathrm{C}$. But in a mass production of large components like bridge or pavement decks, it is a crucial economic consideration to demold the fabricated components as soon as possible and then to place in stacking. If an E-glass/vinyl ester component is fabricated and allowed to cure at room temperature, it definitely occupies the fabrication bed for 24 hours before it can be demolded. In this research work, the resin infusion on the specimens was done at different elevated temperature of $120^{\circ} \mathrm{F}, 150^{\circ} \mathrm{F}$ and $200^{\circ} \mathrm{F}$ and vacuum pressure of 24 in to 27 in of $\mathrm{Hg}$. The specimens were heated for 30 minutes and immediately demolded and preliminary tests were conducted for mechanical properties exactly after 24 hours. It is also important to mention that the viscoelastic characteristics of Vinyl ester resin depend on temperature and hence, our study obliquely refers to its effects on mechanical properties of components manufactured in Vacuum Assisted infusions. Research was also done on variation of mechanical properties of E-glass/ Vinyl ester resin composites cured at $30^{\circ} \mathrm{C}$ and $90^{\circ} \mathrm{C}$ (Ziaee et. al., 1999). Our research work also encompasses the fact that the amount of MEKP added to the Vinyl ester resin also affects the mechanical properties of E-glass/Vinyl ester composites produced in Vacuum Assisted High Temperature infusion.

Figure 3.1 shows the chemical structures of Vinylester oligomers, Cobalt Naphthenate and MEKP. In Vinyl Ester Resin, unsaturated oligomers are kept dissolved in styrene. 


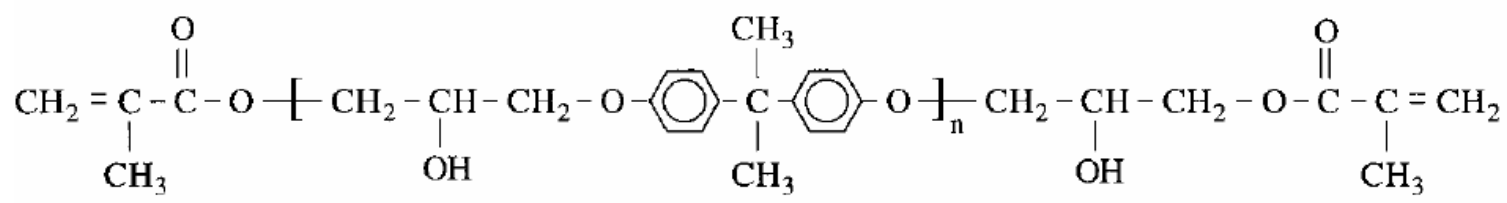

(a)

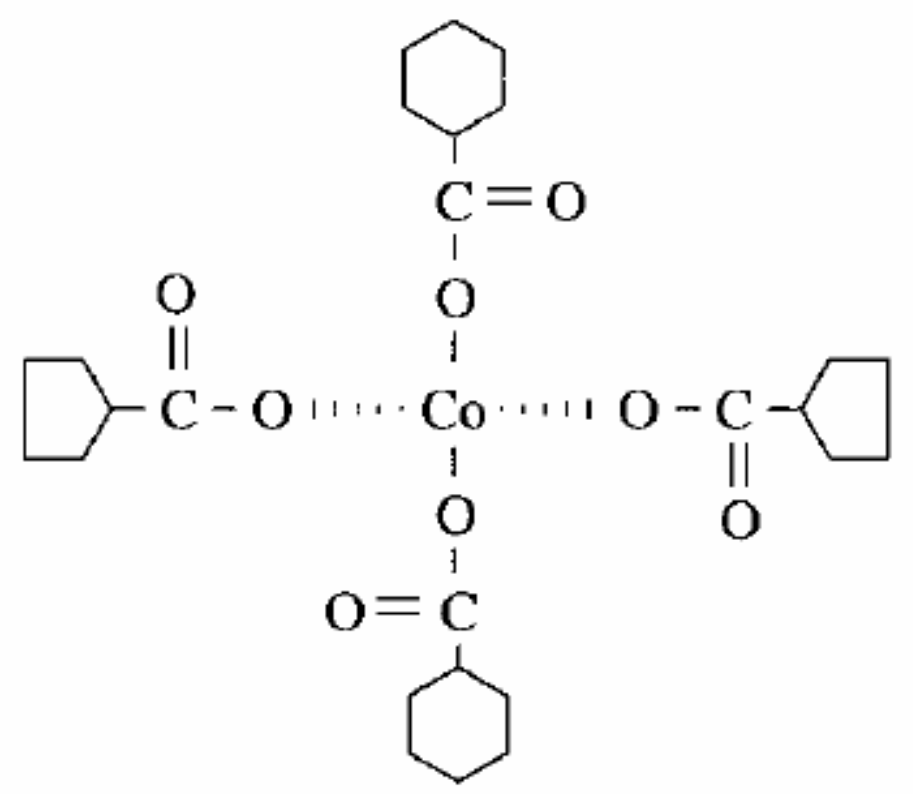

(b)

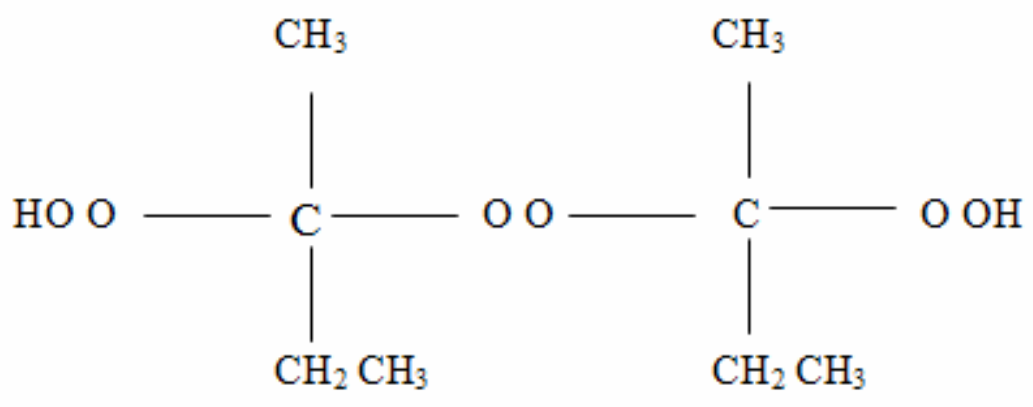

(c)

Figure 3.1 Chemical structure of (a) Vinyl Ester (b) Cobalt Naphthenate (c) MEKP (Ziaee et. al., 1998) 
As shown in Figure 3.1, vinyl esters are methacrylate epoxies. Epoxy molecules do not have a weak chemical link susceptible to chemical attack, because of which vinyl ester is superior in resistance against chemical attacks than polyester. Cobalt Naphthenate is first added to vinyl ester resins as a promoter because they decompose into free radicals. Promoter is a true catalyst and it is not consumed in the reaction. (Thomas et. al., 1997). However, we studied the change in the mechanical properties of a composite infused with vinyl ester resin with different percentages of MEKP addition to the resin. Because, MEKP is not a true catalyst as it is consumed in the reaction. The most common source of free radicals which are needed to initiate the curing reactions in vinyl esters is MEKP. But, initiator MEKP can not cure vinyl ester resins without promoters because they decompose into free radicals very slowly. That is why, Cobalt Naphthenate (CoNap) is generally used as a promoter to decompose MEKP into free radicals. Hence, CoNap is a true catalyst in Vinyl Ester resins curing reaction.

\subsection{Manufacturing of Coupon Test Plates}

Manufacturing details, different production parameters and techniques used in this study are described in a separate twenty five page report submitted to CFC, WVU. There are several proprietary information and pictures, which are protected from open disclosure. We prepared GFRP-Vinyl Ester plates in CFC-WVU research labs. We used a small lab scale platform for production of the 20 " x 12 " composite plates by resin infusion.

The pavement panels were manufactured in three Phases. In Phase-I, the panels were manufactured in Fiber-Tech Industries, Inc., Ohio plant. The necessary modifications and improvements were made in Phase-II manufacturing of the panels in Fiber-Tech Industries, Inc., Washington Court house plant. The required modifications were applied in mass production of the panels. Table 3.3 presents the fabric architectures of panels produced in Phase-I, Phase-II and in mass production of test and full size panels. 
Table 3.3 Fabric architectures of panels produced during different phases of the project

\begin{tabular}{|c|c|c|c|c|c|}
\hline \multirow{2}{*}{$\begin{array}{c}\text { Manufacturing } \\
\text { stage }\end{array}$} & \multirow{2}{*}{ Locations } & \multicolumn{4}{|c|}{ Fabric Density in a given orientation $\left(\mathrm{oz} / \mathrm{yd}^{2}\right)$} \\
\hline & & $\mathbf{0}$ & 90 & 45 & -45 \\
\hline \multirow{6}{*}{ Phase I-test panel } & Core wrapping & 62 & 32.5 & 32.5 & 32.5 \\
\hline & Face carpets & 158.3 & 32.5 & 32.5 & 32.5 \\
\hline & Total in the flange & 220 & 65 & 65 & 65 \\
\hline & $\%$ distribution in flange & 52 & 16 & 16 & 16 \\
\hline & Total in the web & 124 & 65 & 65 & 65 \\
\hline & $\%$ distribution in web & 40 & 20 & 20 & 20 \\
\hline \multirow{6}{*}{$\begin{array}{c}\text { Phase II-test } \\
\text { panel }\end{array}$} & Core wrapping & 48 & 34 & 25.5 & 25.5 \\
\hline & Face Carpets & 105.6 & 74.8 & 0 & 0 \\
\hline & Total in the flange & 153.6 & 108.8 & 25.5 & 25.5 \\
\hline & $\%$ distribution in flange & 49 & 35 & 8 & 8 \\
\hline & Total in the web & 96 & 68 & 51 & 51 \\
\hline & $\%$ distribution in web & 36 & 26 & 19 & 19 \\
\hline \multirow{6}{*}{$\begin{array}{c}\text { During Mass } \\
\text { Production- Test } \\
\text { panel }\end{array}$} & Core wrapping & 25.5 & 23 & 15.8 & 17 \\
\hline & Face carpets & 63 & 68 & 0 & 0 \\
\hline & Total in the flange & 88.5 & 91 & 15.8 & 17 \\
\hline & $\%$ distribution in flange & 42 & 42 & 7 & 8 \\
\hline & Total in the web & 51 & 46 & 31.6 & 34 \\
\hline & $\%$ distribution in web & 32 & 28 & 19 & 21 \\
\hline \multirow{6}{*}{$\begin{array}{c}\text { Mass Production } \\
\text { of final prototype } \\
\text { panel }\end{array}$} & Core wrapping & 34 & 31.6 & 23.7 & 25.5 \\
\hline & Face carpets & 59.5 & 57.5 & 12 & 12 \\
\hline & Total in the flange & 93.5 & 89.1 & 35.7 & 37.5 \\
\hline & $\%$ distribution in flange & 36 & 35 & 14 & 15 \\
\hline & Total in the web & 68 & 63.2 & 47.4 & 51 \\
\hline & $\%$ distribution in web & 29 & 28 & 21 & 22 \\
\hline
\end{tabular}

Note: Core wrapping consists of wrapping around rectangular tube 
The percentage distribution of fibers along 0/90/45/-45 degrees at the flanges and webs of panels during different stages of manufacturing are presented in Figures 3.2 to 3.11 .

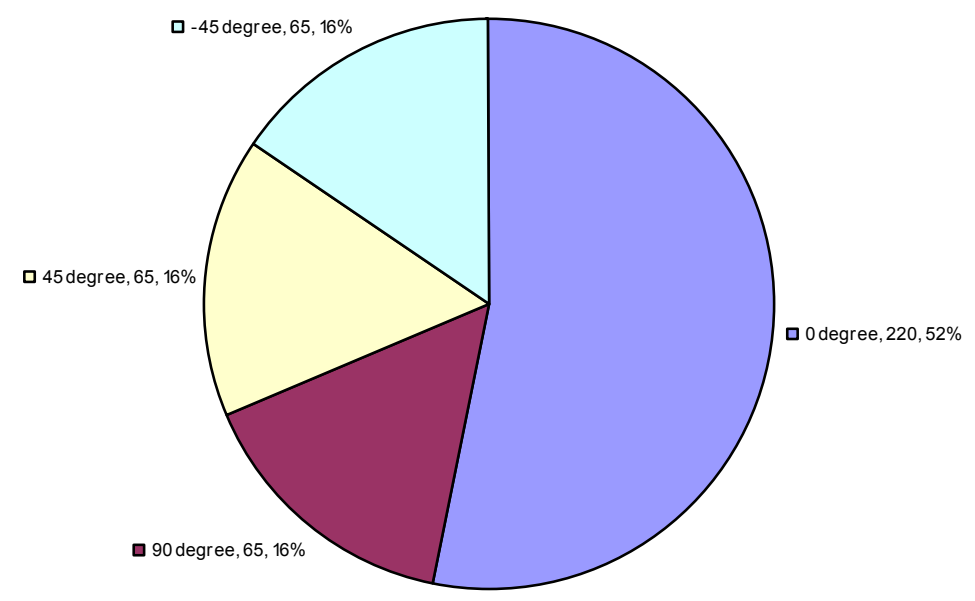

Figure 3.2 Distribution of fibers in the flanges along four directions, phase I panels $\left(\mathbf{o z} / \mathbf{y d}^{2}\right)$

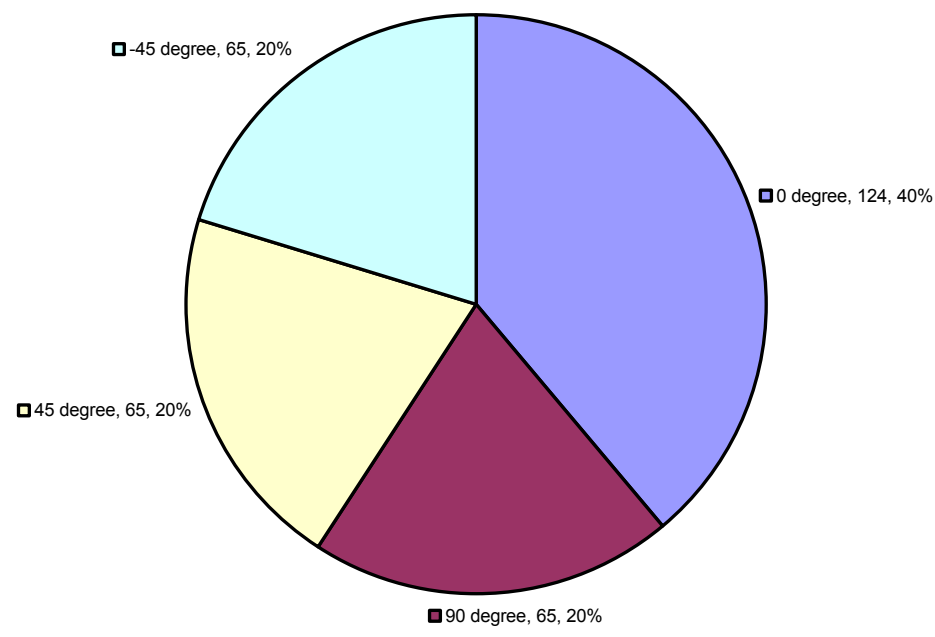

Figure 3.3 Distribution of fibers in the webs along four directions, phase I panels $\left(\mathbf{o z} / \mathbf{y d}^{\mathbf{2}}\right)$ 


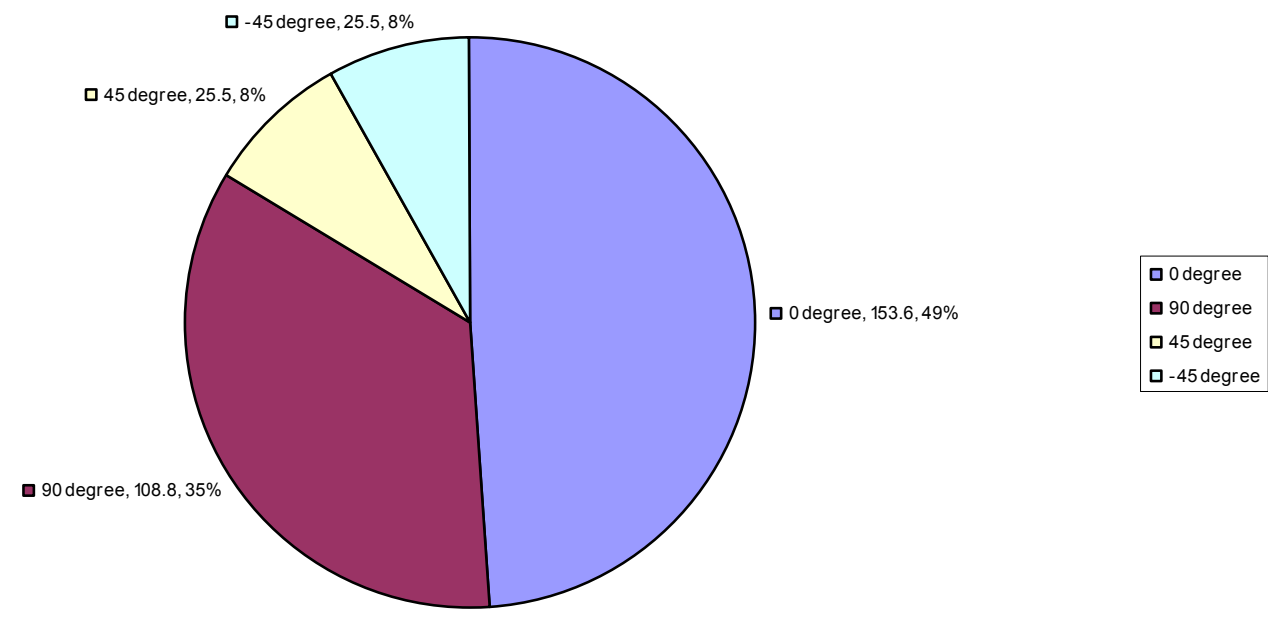

Figure 3.4 Distribution of fibers in the flanges along four directions, phase II panels $\left(\mathbf{o z} / \mathbf{y d}^{\mathbf{2}}\right)$

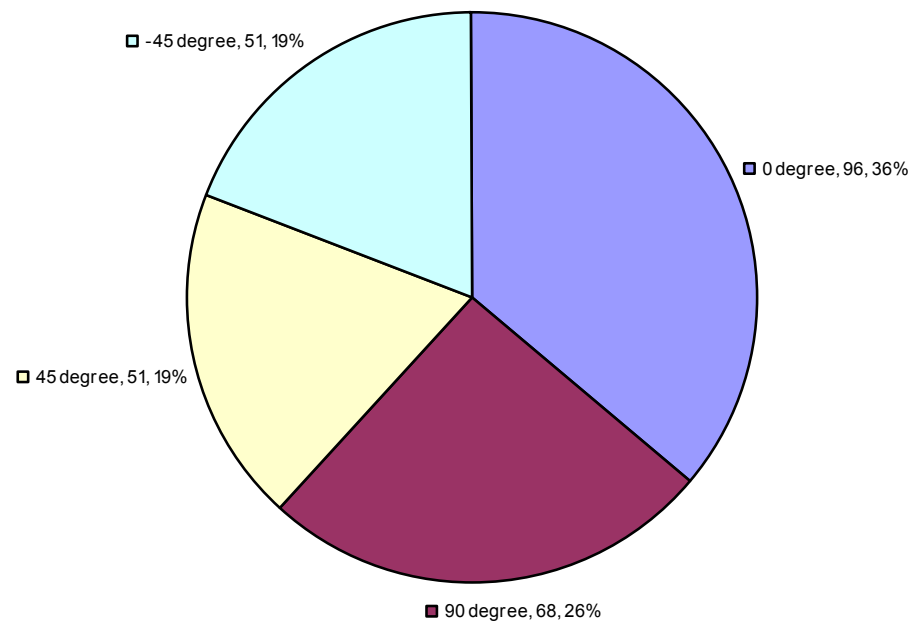

Figure 3.5 Distribution of fibers in the webs along four directions, phase II panels $\left(\mathrm{oz} / \mathrm{yd}^{2}\right)$ 


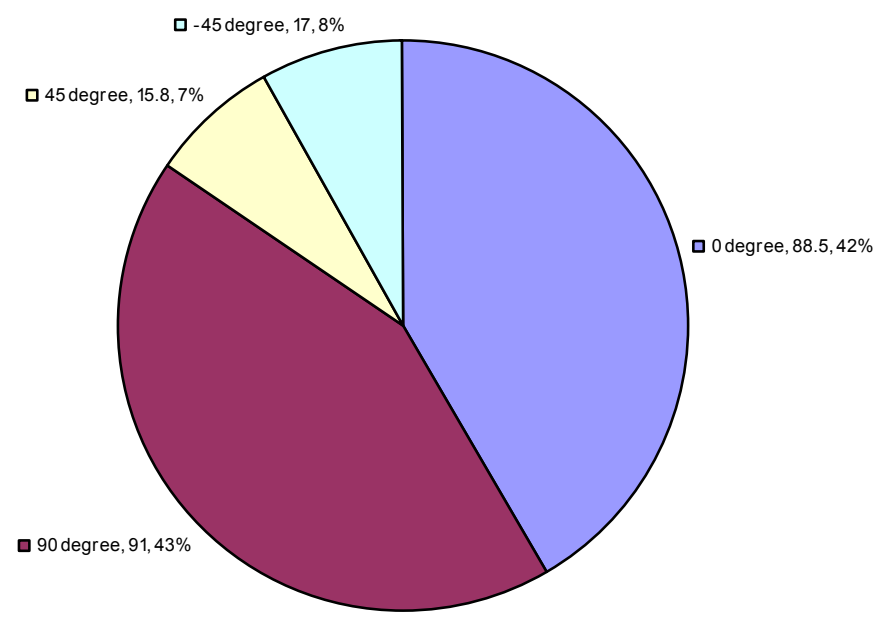

Figure 3.6 Distribution of fibers in the flanges along four directions, test panel produced during mass production $\left(\mathrm{oz} / \mathrm{yd}^{2}\right)$

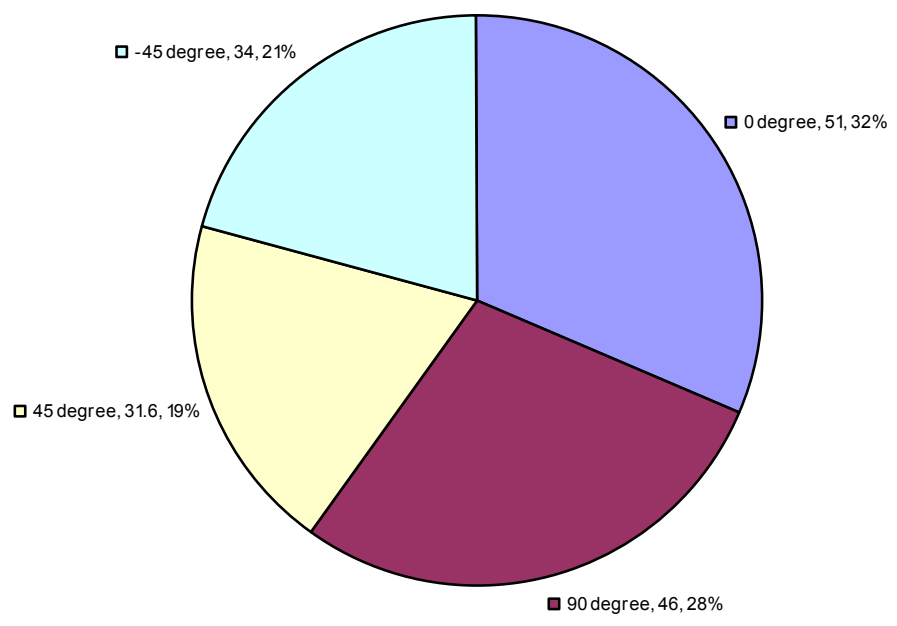

Figure 3.7 Distribution of fibers in the webs along four directions, test panel produced during mass production $\left(\mathrm{oz} / \mathrm{yd}^{2}\right)$ 


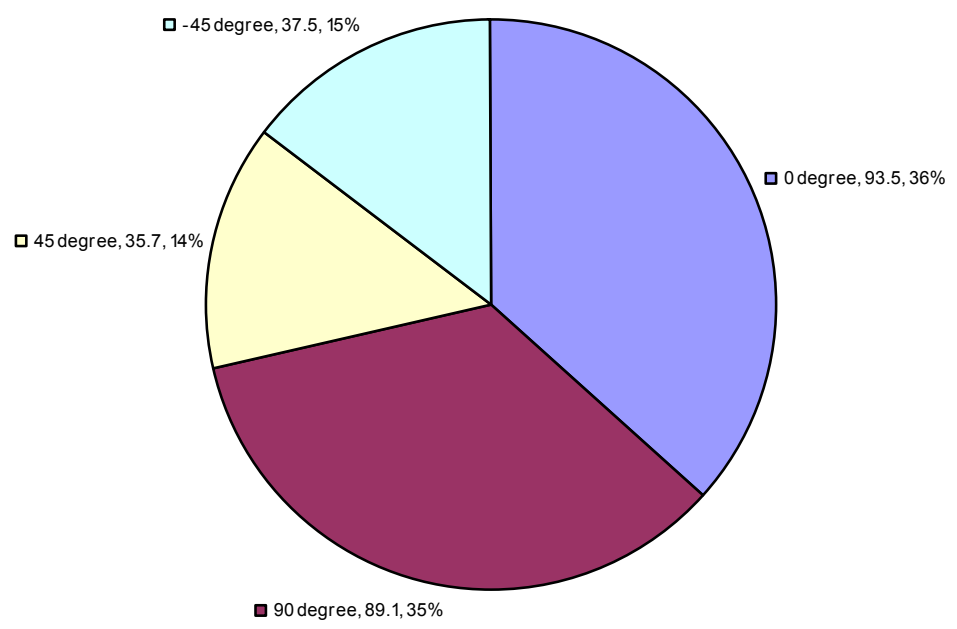

Figure 3.8 Distribution of fibers in the flanges along four directions, actual panels produced during mass production $\left(\mathrm{oz} / \mathrm{yd}^{2}\right)$

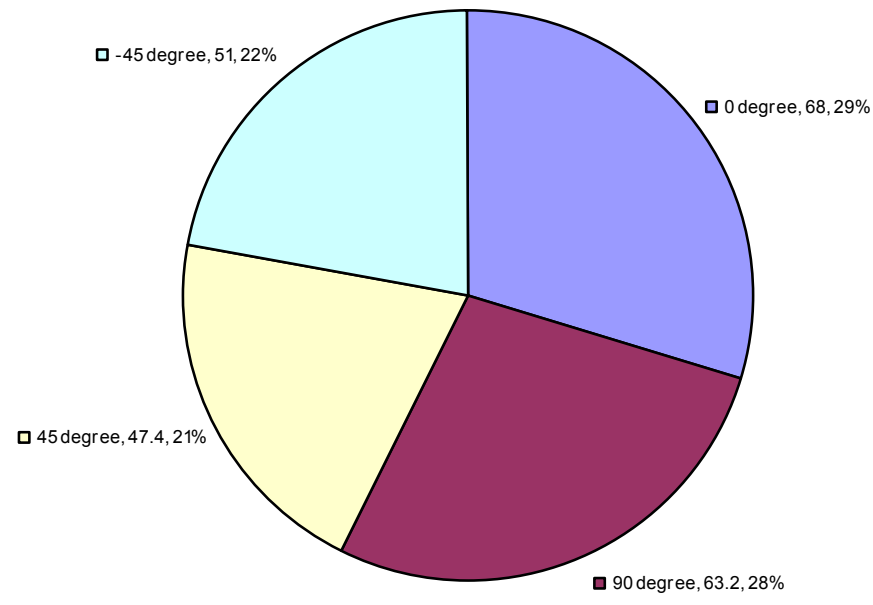

Figure 3.9 Distribution of fibers in the webs along four directions, actual panels produced during mass production $\left(\mathrm{oz} / \mathrm{yd}^{2}\right)$ 


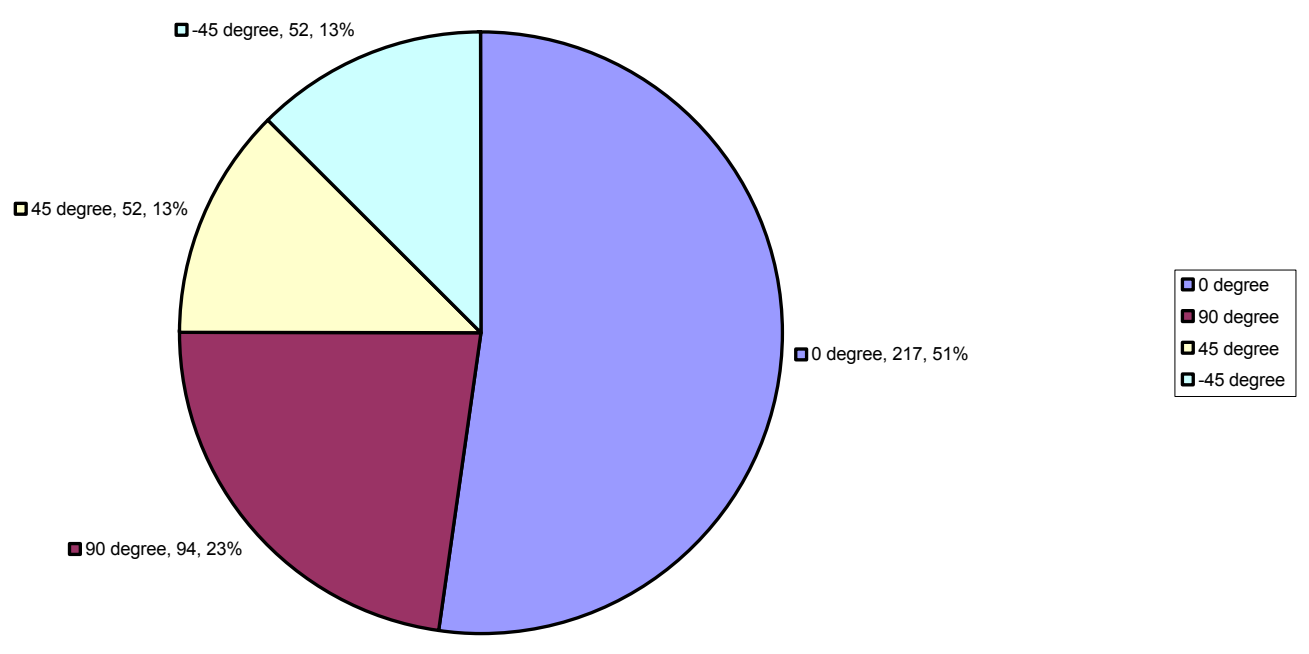

Figure 3.10 Distribution of fibers in the flange along four directions of Prodeck 4 produced by Pultrusion (oz/yd $\left.\mathbf{d}^{2}\right)$

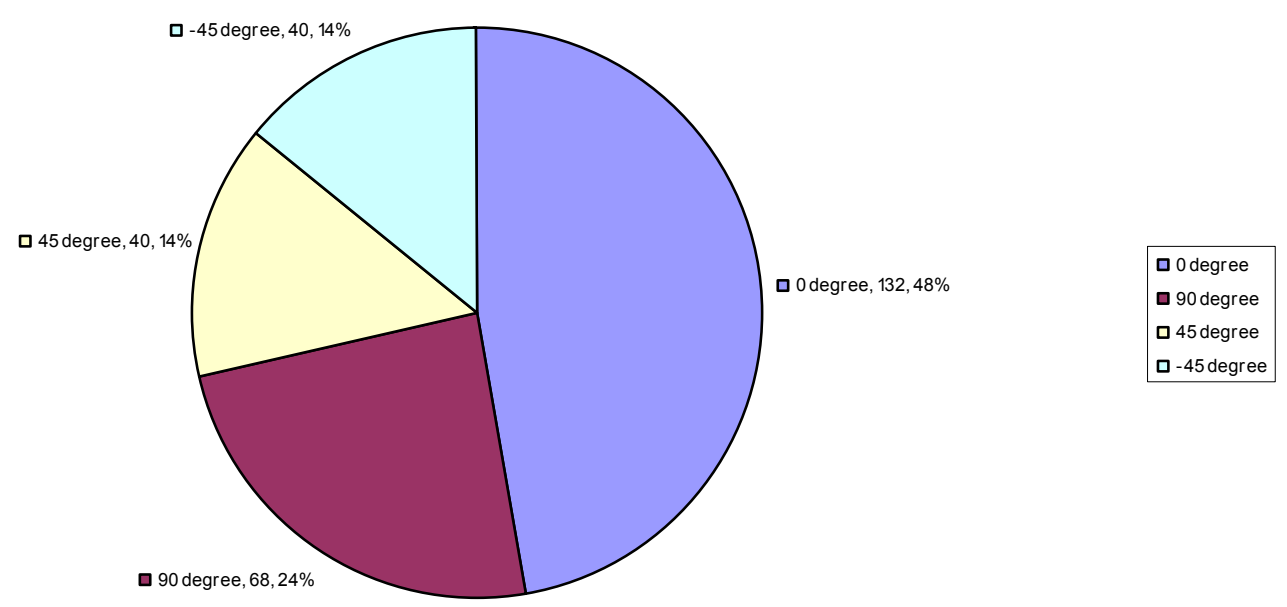

Figure 3.11 Distribution of fibers in the webs along four directions of Prodeck 4 produced by pultrusion $\left(\mathrm{oz} / \mathrm{yd}^{2}\right)$ 
Figure 3.12 shows a13 ft $\times 8 \mathrm{ft} 10$ inch panel manufactured for field installation as a modular FRP pavement panel near new Morgantown High School, WV in spring 2008.

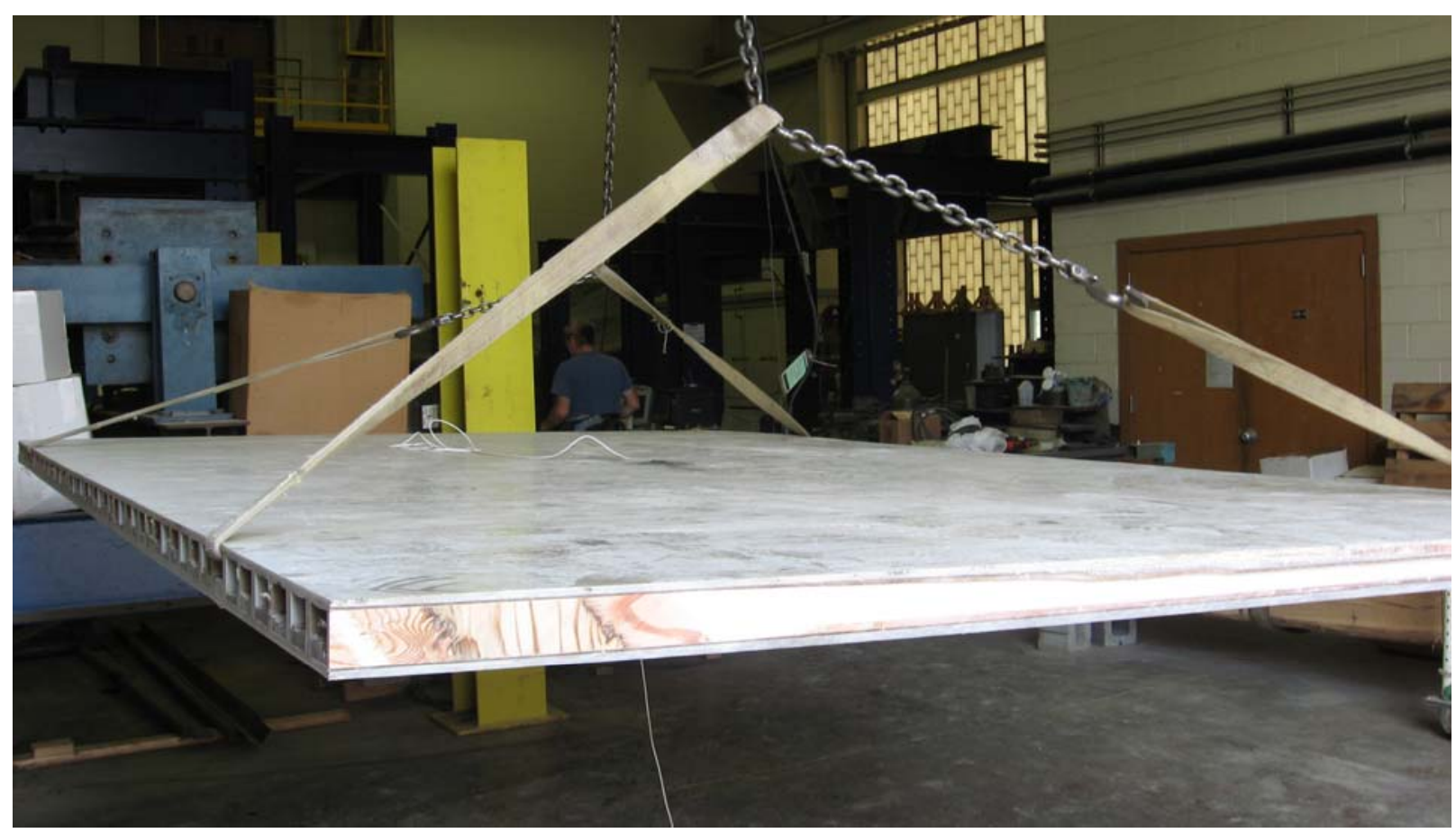

Figure 3.12 FRP panel (13 ft $x 8 \mathrm{ft} 10$ inch) being moved to the testing bay

\section{Improvements recommended in the mass manufacturing of the panels}

Following improvement are suggested for enhancing mechanical properties of the panels produced by HT-VARIM.

\section{(1) Prevent resin accumulation}

Figure 3.13 shows a huge amount of resin accumulation within the hollow cells of the panel all along the bottom surface of the panel. Also, at some web locations extra resin accumulation could be seen. These extra resin increases the weight and cost of the panel. 


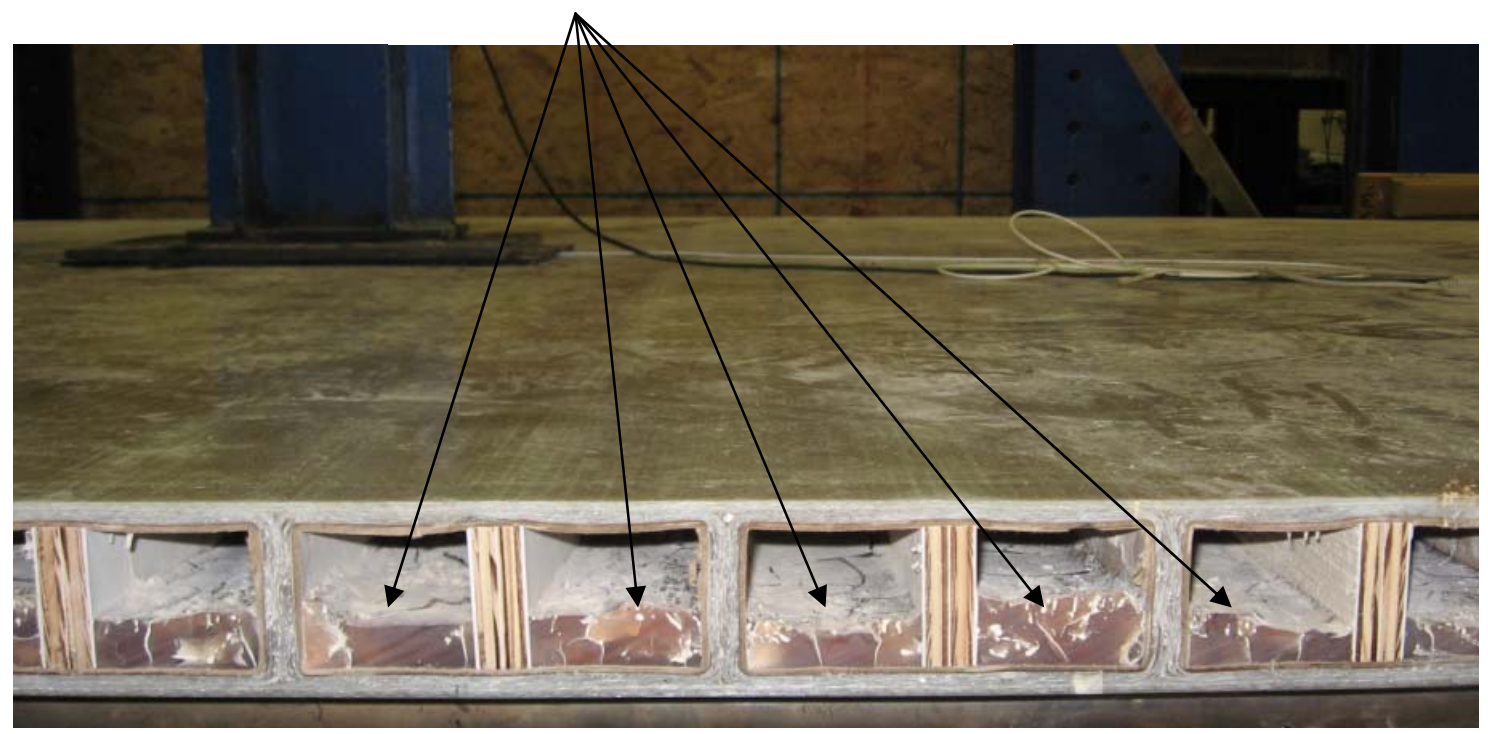

Figure 3.13 Resin accumulations at the bottom surface

\section{(2) Non-uniform web thickness}

Few of the webs were observed to be thicker than the average web thickness of 0.335 inches because of high resin accumulation in those webs.

\section{(3) Removal of wooden supports}

The wooden pieces used for temporarily supporting the cardboard cells in the middle during the manufacturing must be taken out after curing to avoid additional weight, possible moisture absorption and rotting in the field.

\section{(4) Low FVF at the web}

Fiber volume fraction in the web was only $33 \%$ compared to $55 \%$ at the top and bottom flanges of the test panel produced during the mass production of the actual panels. The FVF at webs and flanges of the panels produced during Phase I and Phase II were uniform (about 50\%). Therefore, quality of manufacturing of the panel must be controlled.

Figure 3.14 and 3.15 show the full size panels stacked at the WVDOH storage yard for installation as pavement structures in Spring 2009. 


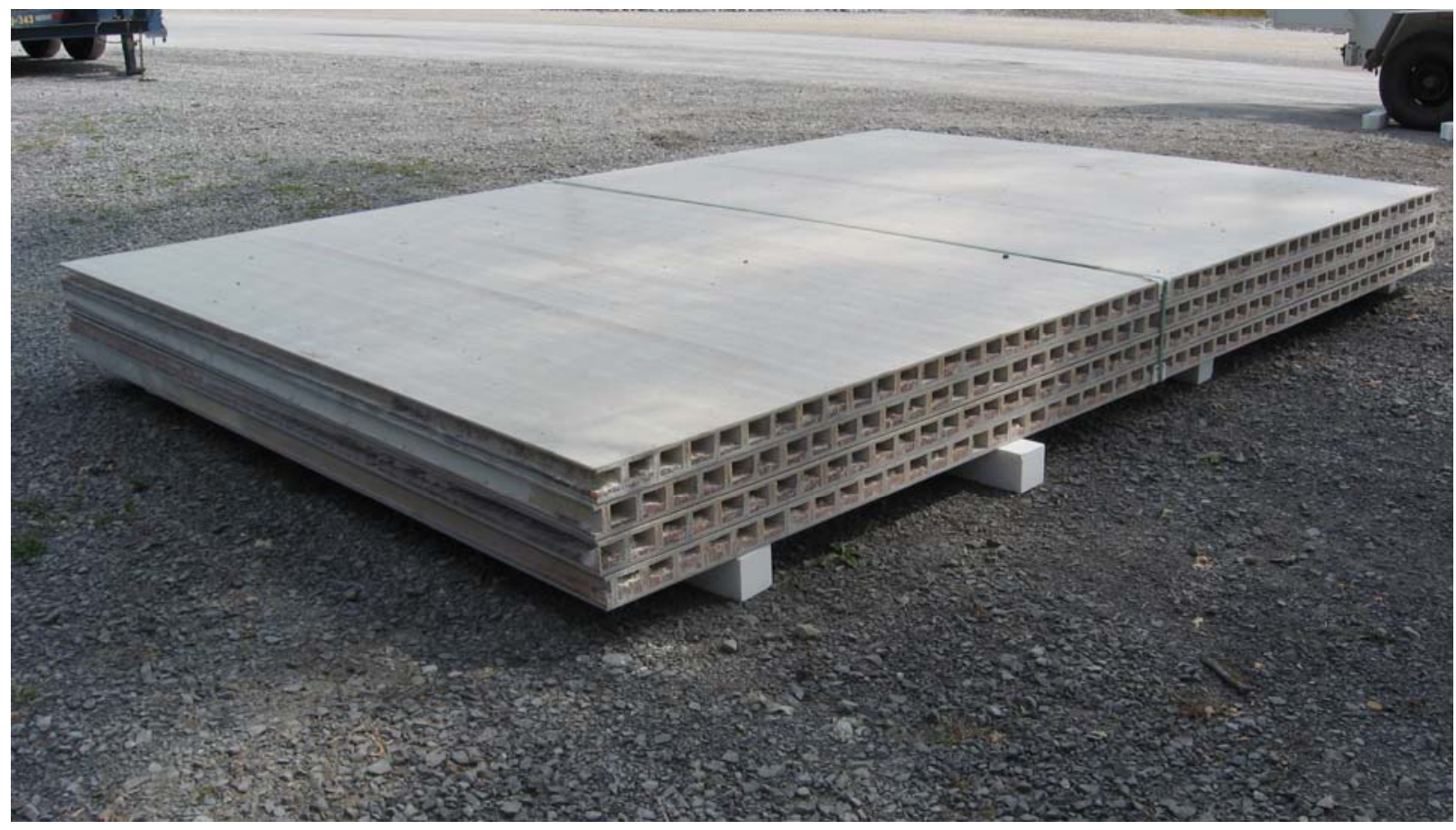

Figure 3.14 Stacked FRP pavement panels ready for installation

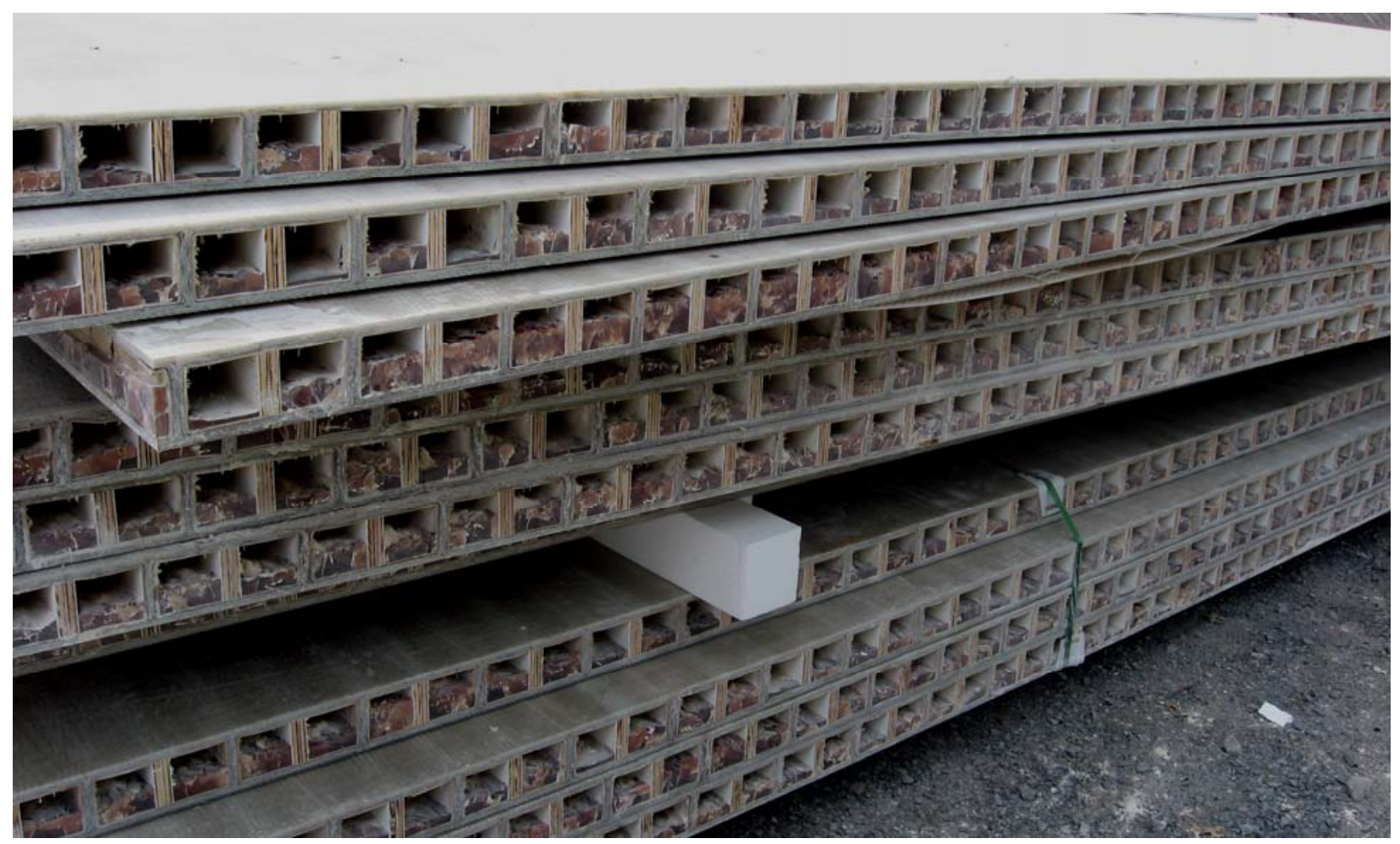

Figure 3.15 Mass produced FRP pavement panels at the WVDOH storage yard 
Summary: In this chapter, we discussed about fabrics, resins and their properties used for sample preparation. Fiber architectures used for panels manufactured during different phases of the project were elaborated. In the next chapter, we will discuss about different test set up, sample preparation and testing procedures used for finding mechanical properties of the composites panels manufactured by HT-VARIM at coupon and component level. 


\section{CHAPTER 4 LABORATORY TESTING DETAILS}

\subsection{Introduction}

Details of different tests conducted in the laboratory on both the coupon and panel specimens are provided in this chapter. As mentioned in chapter 3, there are two categories of coupon specimens- (1) coupon specimens cut out from the plates manufactured in the laboratory that were tested to evaluate and optimize process parameters for HT-VARIM. (2) coupon specimens cut out from webs and flanges of panels produced by Fibertech Inc. Specimens were cut from the center and the edges of an 8 ' wide panel to verify the uniformity of resin infusion along the width and span. Test procedures described herein, include tension (Section 4.2), bending (Section 4.3) and shear (Section 4.4) including sample preparation and test set-up, burn out test procedure (Section 4.5). Section 4.6 and 4.7 explains full scale panel testing procedure and test set up. Scanning Electron Microscope procedure is provided in Section 4.8, to evaluate void content of composite parts.

\subsection{Coupon Tension Test}

Tension test specimen preparation and test set-up are described in the following sections. Tension tests were performed as per ASTM D 3039.

\subsubsection{Specimen Preparation}

The total length of each tension test specimen was 20\%. On either ends of a specimen 5 inches were ground to roughen the surface to facilitate proper adhesion of grips. FRP tabs (1/4" thick) of 5 " x 1 " length were cut from 12 " x 12 " plates that were also surface ground for bonding the tabs (Figure 4.1). The tabs were bonded to tension coupons using an epoxy based adhesive supplied by Eager Plastics in two parts ie., Part A: EP6151 and Part B: Activator EP 6151. Both parts were mixed in 1:1 ratio and applying on roughened surface of the coupons and tabs. The glue was applied with pressure using C-clamps and cured for 24 hours to ensure proper adhesion. Tabs help avoid crushing of specimens and grip failures. Strain gages were mounted in the longitudinal direction (Figure 4.1) at the center of each test specimen to evaluate tensile strength and stiffness. 


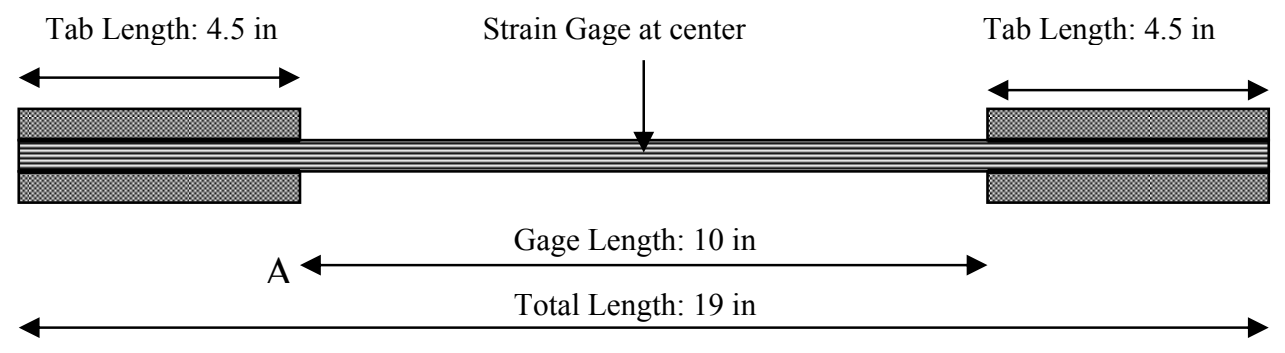

Figure 4.1 Strain gage on tension test specimens

\subsubsection{Test Set-up and Test Procedure}

Tension specimens were tested using a universal testing machine (BALDWIN, Figure 4.2) as per ASTM D3039. Data acquisition system connected to a computer was used to record load and strain. Coupons were loaded until failure, to evaluate ultimate failure stress and strain of the coupon.

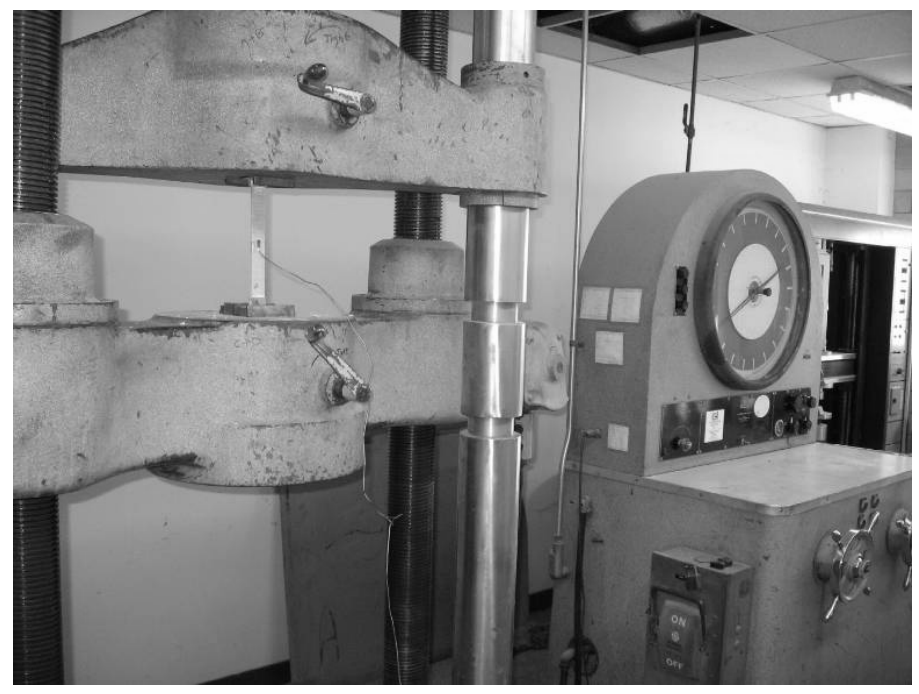

Figure 4.2 Baldwin machine used for tension test

\subsubsection{Tension Test Calculations}

Tensile strength

$$
\sigma_{u l t}=\frac{P_{u l t}}{w t}
$$

Tensile modulus

$$
E_{s s}=\frac{\sigma}{\varepsilon}
$$


Where, P - Applied load on the specimen (lbs)

w - Average width of specimen (in)

$\mathrm{t}$ - Thickness of specimen (in)

$\mathrm{A}=\mathrm{W} \times \mathrm{T}=$ Cross-sectional area of the specimen $\left(\mathrm{in}^{2}\right)$

$\mathrm{E}_{\mathrm{ss}}-$ Calculated from slope of elastic zone of Stress Vs. Strain curve

\subsection{Coupon Bending Test}

The test specimens were cut as per dimensions recommended by ASTM D790 for a four point bending test. The specimen preparation and test set-up for above mentioned ASTM tests are described in the following sections.

\subsubsection{Specimen Preparation}

The 8" x 1" specimens were tested with a span of 6" with 1" overhang at each end. Once the test specimens were ready, strain gages were installed on the tension face of each bending specimen to evaluate bending strength and stiffness as shown in the Figure 4.3.

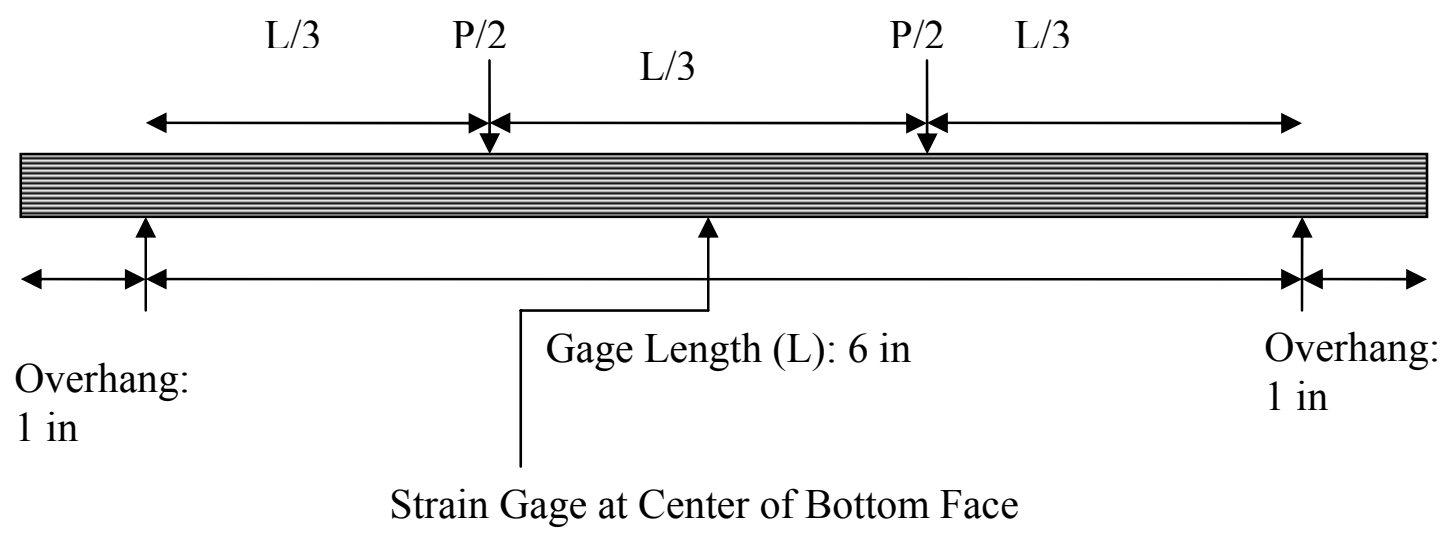

Figure 4.3 Strain gage on bending test specimens

\subsubsection{Test Set-up and Test Procedure}

Bending tests were conducted using an Instron machine Model 8501. The Instron cross head speed was set as per ASTM D790. Four point bending test was performed with simply supported conditions with point loading at $1 / 3$ of the overall test span. Strains 
were recorded at constant load intervals through a data acquisition system. The specimens were tested to failure and the corresponding failure strains were noted. A typical test set-up is shown in Figure 4.4.

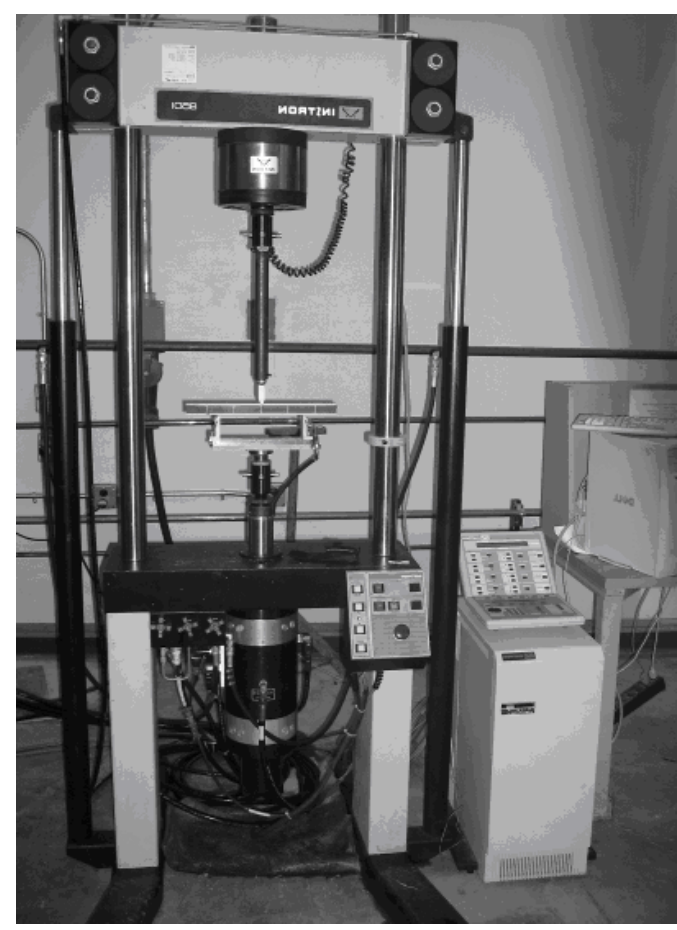

Figure 4.4 Instron machine used for coupon bending test

\subsubsection{Bending Test Calculations}

Equations 4.3 and 4.4 are used to calculate bending strength and stiffness, from the data obtained from four-point bending tests on specimens with 3 equal span segments.

Bending modulus (based on stress-strain curve): $E_{x}^{B}=\frac{\sigma}{\varepsilon}$

Bending Modulus (based on load-deflection curve): $\mathrm{E}_{\mathrm{x}}^{\mathrm{B}}=\frac{23 \mathrm{PL}^{3}}{108 \mathrm{~b} \delta \mathrm{d}^{3}}$

The flexural strength is given by $\sigma_{\text {ult }}=\frac{\mathrm{PL}}{\mathrm{bd}^{2}}$, for rectangular section with 3-equal load span segments.

Where, $\mathrm{P}$ is the maximum load.

$$
\begin{aligned}
& \sigma=\text { bending stress }=\frac{P L}{b d^{2}}, \varepsilon=\text { bending strain } \\
& \mathrm{m}=\mathrm{P} / \delta=\text { Slope of Elastic Zone of Load Vs Deflection curve }
\end{aligned}
$$


$\delta=$ Deflection

$\mathrm{L}=$ Span Length of the specimen (in)

$\mathrm{L} 1=\mathrm{L} 2=\mathrm{L} / 3=$ Load Span (in)

$\mathrm{b}=$ Width of specimen (in)

$\mathrm{d}=$ Thickness of the specimen (in)

\subsection{Coupon Short-Beam Shear Test}

Short-beam shear test was conducted on test specimens cut from test panels to evaluate out of plane shear strength. The specimens were tested under three point bending according to the recommendations in ASTM D2344-84.

\subsubsection{Test Specimen Preparation}

Test coupons were prepared by cutting the specimens in both the longitudinal and transverse directions from web and flange of a panel. The specimen dimension was 2 " $\mathrm{x}$ 0.5 ". The ratio of span to thickness was chosen to induce laminate delamination under applied shear. The thickness of the specimens from web and flange were 0.35 " and 0.50 " respectively. The schematic diagram of short beam shear test is show in Figure 4.5.

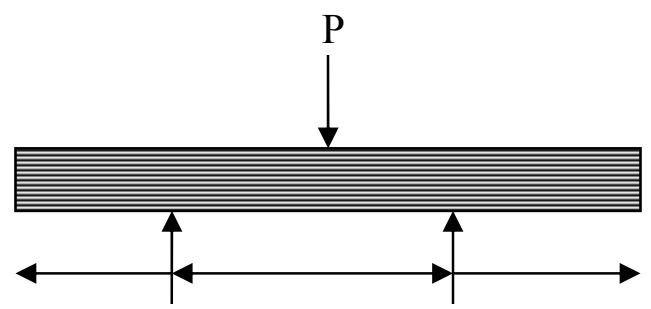

Overhang: 0.5 in Short Span: 1 in Overhang: 0.5 in

Figure 4.5 Short-beam shear test

\subsubsection{Test Set-up and Test Procedure.}

For coupon specimens, a small load capacity universal testing machine (Instron) was used to conduct three-point bending tests. Coupon specimens were placed on simple supports of the testing apparatus and loading crosshead was aligned on the mid-span of 
the test specimens. Test specimens were loaded at a rate of $0.05 \mathrm{in} / \mathrm{min}$. Short beam shear testing of coupon specimens is shown in Figure 4.6.

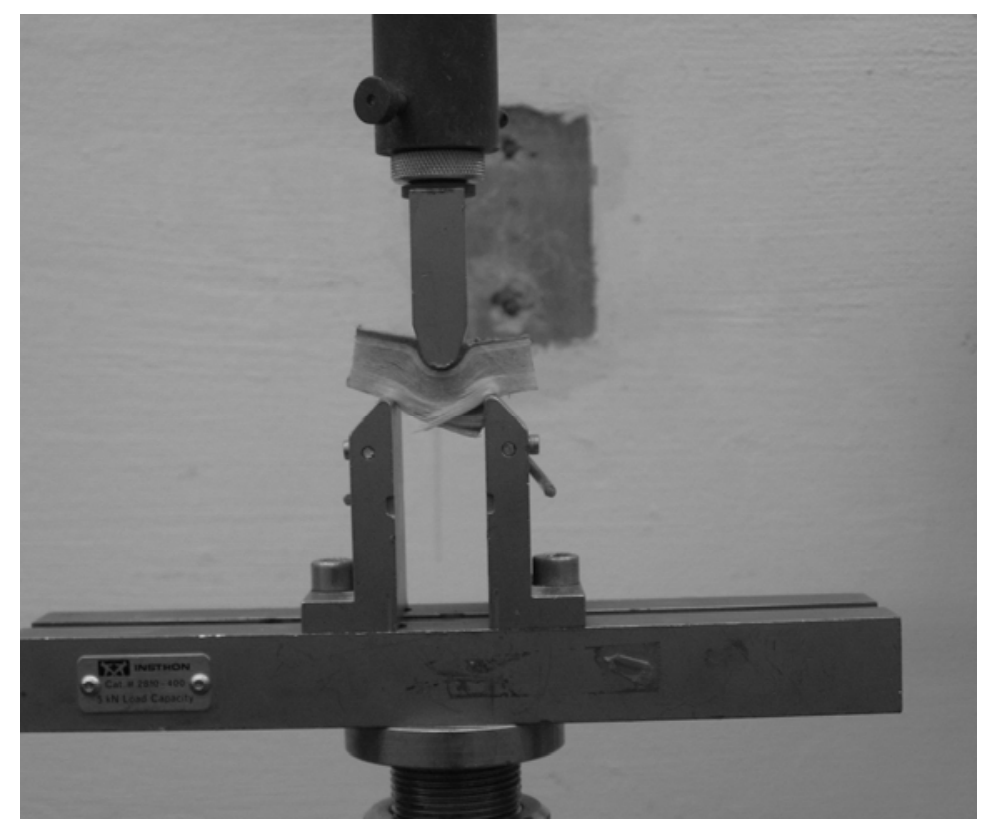

Figure 4.6 Short beam shear test

\subsubsection{Short Beam Shear Test Calculation}

The maximum out-of-plane shear strength of a specimen with rectangular cross section based on the simple beam theory is:

$\mathrm{T}_{\mathrm{s}}=0.75 \frac{\mathrm{P}_{\mathrm{ult}}}{\mathrm{A}_{\mathrm{w}}}$

where, $\mathrm{P}_{\text {ult }}$ is a failure load and $\mathrm{A}_{\mathrm{w}}$ is the web area of the specimen.

\subsection{Burn-out Test}

\subsubsection{Burn out Test Specimens}

Fiber Volume Fraction (FVF) test was carried out to determine the fiber volume (or weight) content of composite constituents. The tests were performed as per ASTM D 3171. Specimens were cut to a dimension of 1 " $\mathrm{x} 1$ " and measured to the nearest 0.001 inches using a vernier caliper. 


\subsubsection{Test Procedure and Set Up}

Each specimen was placed in a preweighed crucible. The crucible (along with specimen) was kept in a preheated furnace (Isotemperature Muffle Furnace, Model 550-58) at $600^{\circ}$ C (Figure 4.7) for 3 hours. The specimens were taken out from the furnace and the crucible along with the fibers was further weighed.

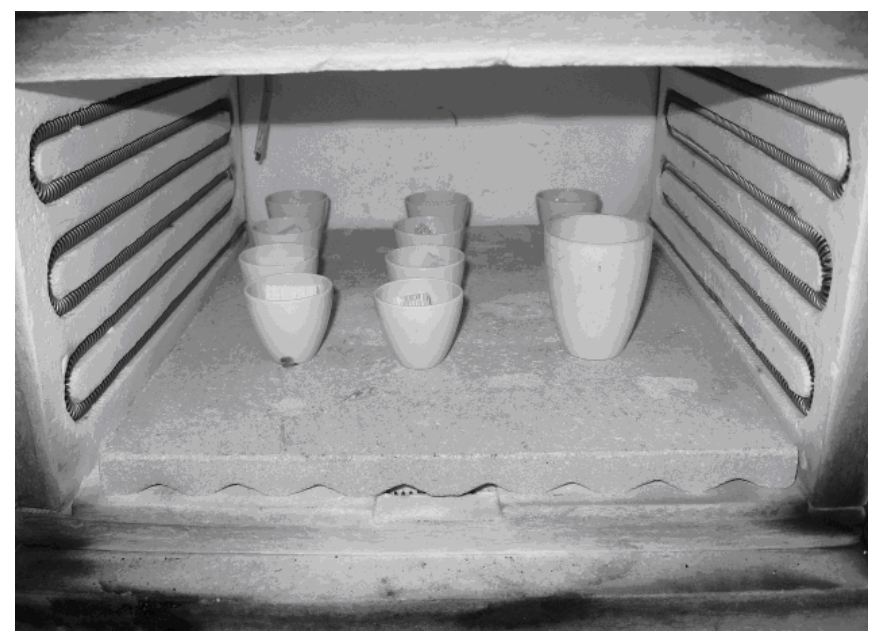

Figure 4.7 Muffle furnace

\subsubsection{Fiber Volume Fraction Calculation}

Step 1: Measure dimension of the composite sample - Length $(\mathrm{L}$ in $\mathrm{cm})$, Width (W in $\mathrm{cm})$ and Thickness ( $\mathrm{T}$ in $\mathrm{cm})$.

Step 2: Measure the weight of empty crucible ( $\mathrm{W}_{\mathrm{C}}$ in $\left.\mathrm{gms}\right)$

Step 3: Measure the weight of crucible + sample $\left(\mathrm{W}_{\mathrm{c}+\mathrm{s}}\right.$ in gms) before burn-out

Step 4: Measure weight of fabric (left after resin burn) + crucible $\left(\mathrm{W}_{\mathrm{f}+\mathrm{c}}\right.$ in gms) after burn-out

Step 5: Evaluate FVF $=\frac{\mathrm{W}_{\mathrm{f}+\mathrm{c}}-\mathrm{W}_{\mathrm{C}}}{\rho \mathrm{LWT}} \times 100$

Where, $\rho$ is density of fiber $=2.522 \mathrm{gm} / \mathrm{cc}$.

\subsection{Three Point Bending Test of Panel}

The test panels manufactured through HT-VARIM during different phases of the project were tested under three point bending load. 


\subsubsection{FRP Panel Specimen Preparation}

Two panels with dimensions of 52 inch $\times 18.75$ inch $\times 3$ inch with 4 complete cells and 52 inch $\times 16$ inch $\times 3$ inch were tested under three point bending. Specimens were tested under three point bending in the cell direction (strong axis) of FRP decks. Rosette strain gages were mounted at the bottom surfaces of the test panels in the longitudinal and transverse directions. Dimension of typical test panel of sample 1 and strain gage positions are shown in Figure 4.8.

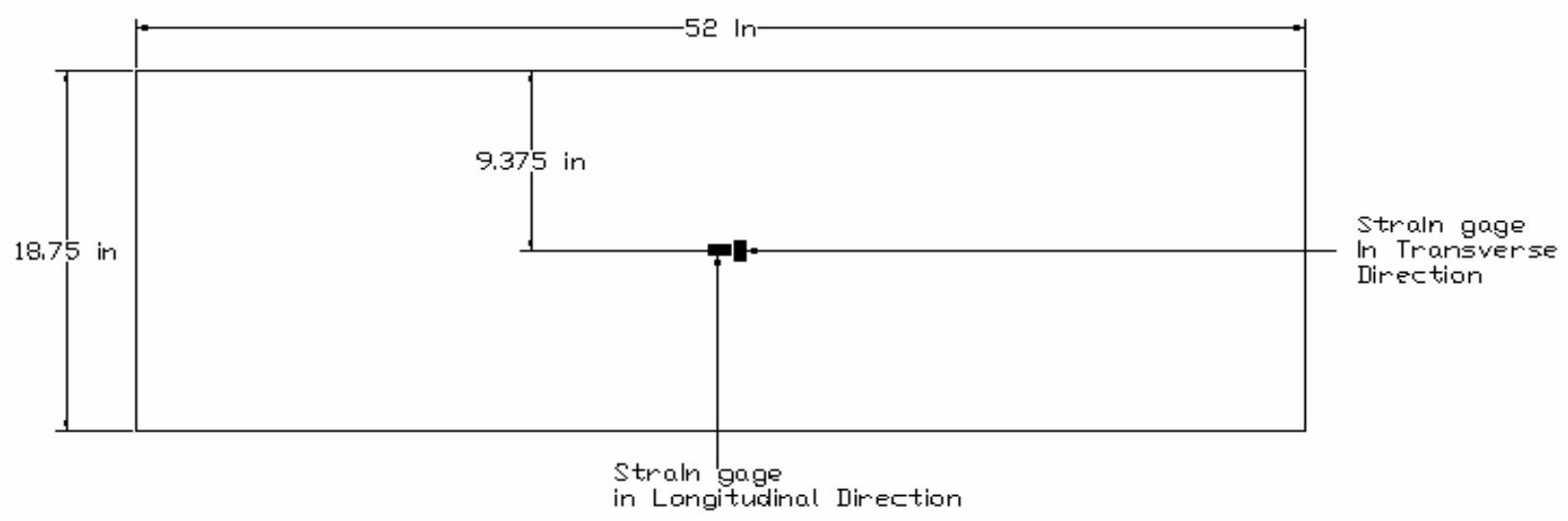

Figure 4.8 Dimensions and strain gage location of the test panel

\subsubsection{FRP Panel Test Set-up and Procedure}

For the three point bending test, multi-cell FRP panel specimens were placed on steel roller support system on trapezoidal concrete blocks with their cells running parallel to their span. A test span of 46 inches and 3 in of overhang on each side were maintained. MTS loading actuator was used to induce a concentrated load at the mid span of the test specimens. 20 inch x 10 inch patch was used to apply a concentrated load $(20$ inch $\times 10$ inch patch) to simulate HS25 truck wheel load. Vertical deflection at mid span was measured by using a linear variable differential transducer (LVDT) which was connected to a data acquisition system. Thus, vertical deflection and strain data were acquired by connecting LVDT and strain gages to a data acquisition system. Those data were managed through using strain smart software. Three point bending test set up is shown in Figure 4.9. 


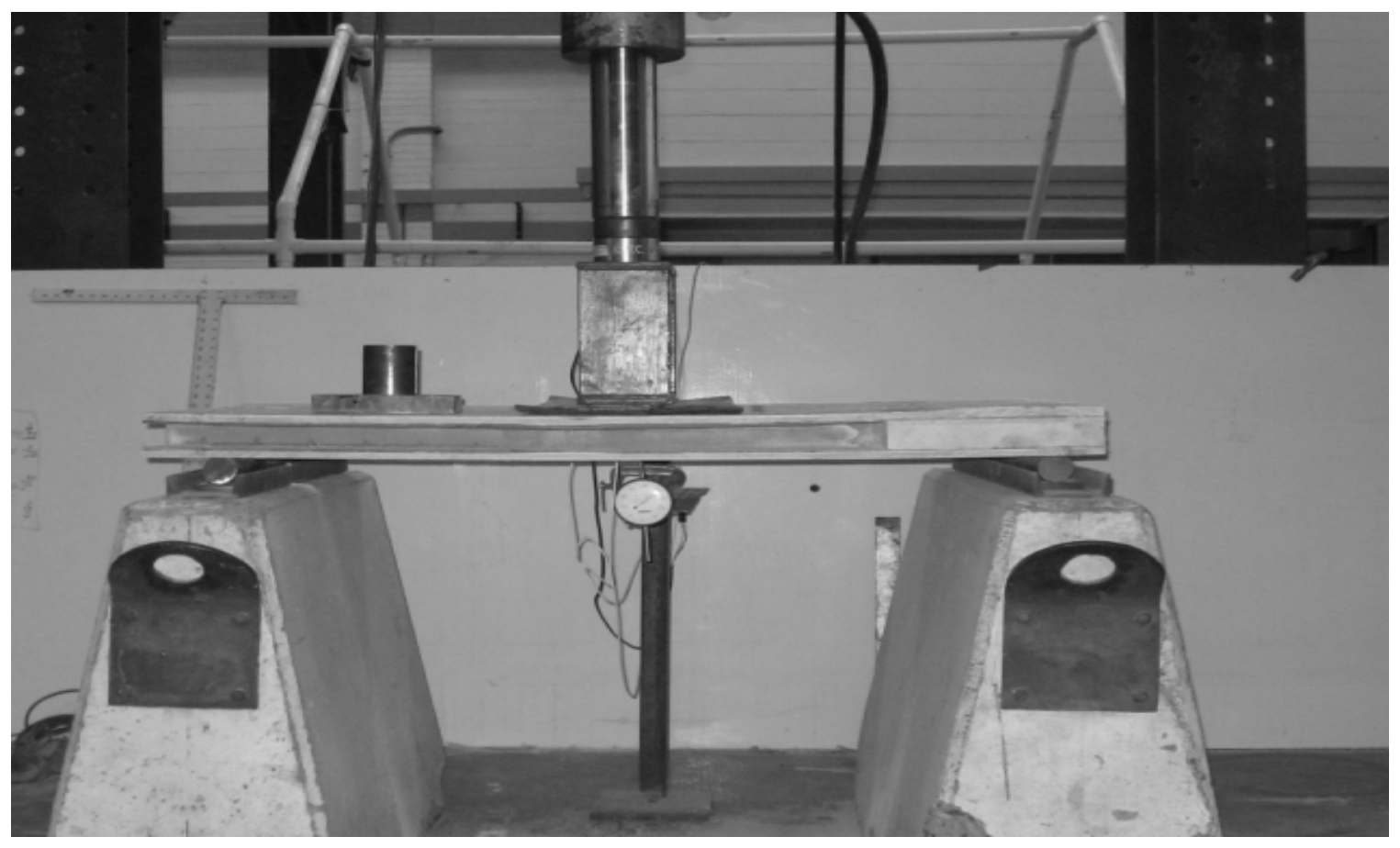

Figure 4.9 Test set up for three point bending test of panel

\subsection{Fatigue Test of the Panel}

To study the behavior of the panel under cyclic loading fatigue tests were carried out as explained below in section 4.7.1.

\subsubsection{Specimen Preparation}

Strain gages were attached at the center of the top and bottom flanges of the panel. Before applying fatigue load on the panel, static test was conducted on the specimen. Section 4.7.2 explains the test set up and procedure.

\subsubsection{Test Set up and Procedure}

The panels manufactured by HT-VARIM method have several structural applications. In this research, they will be filed implemented as a pavement panels supported on a aggregate/asphalt subbase. Therefore, a bin was filled with gravel and the top surface was leveled prior to placing the panel over the gravel as shown in Figure 4.10. 


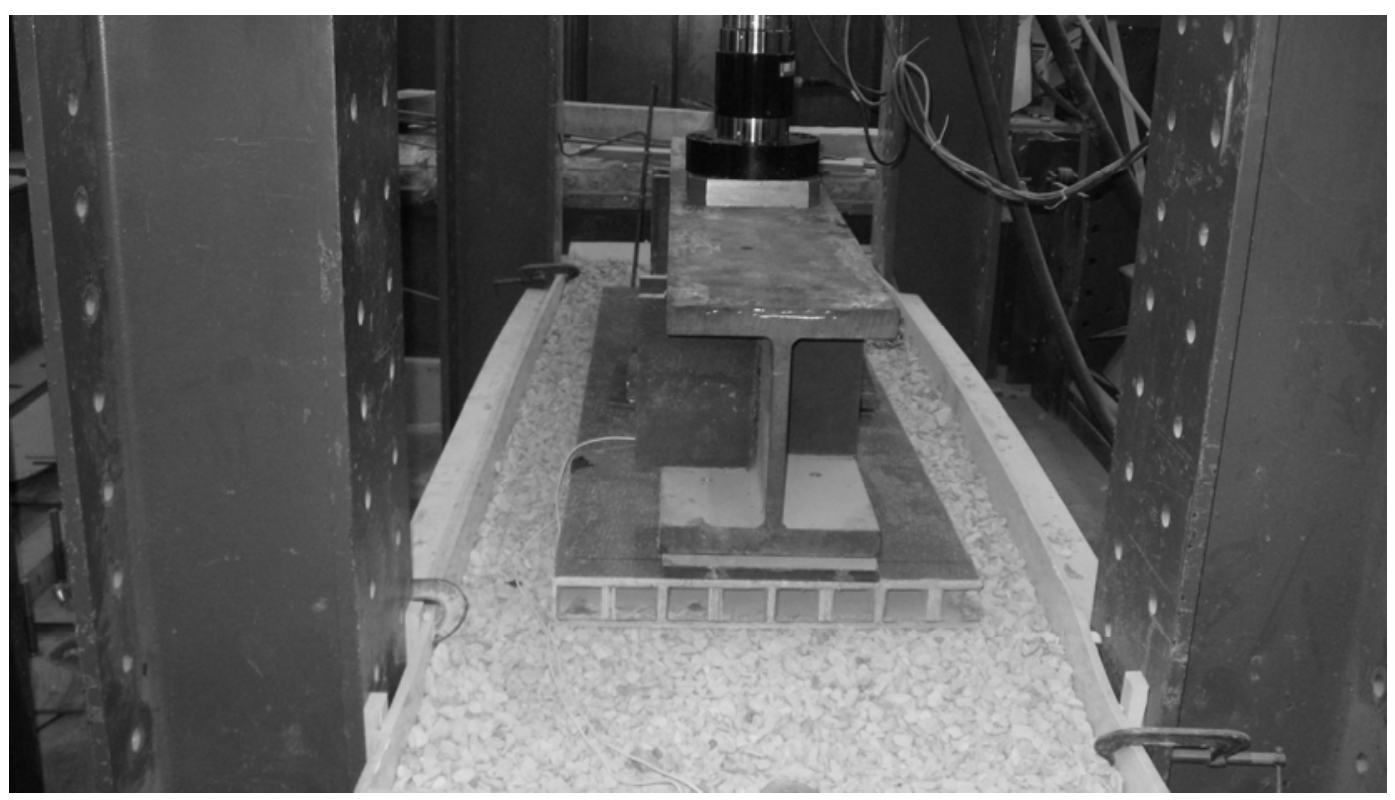

Figure 4.10 Panel placed over the gravel under fatigue load

A 20 inch X 10 inch elastomeric pad was placed on the panel with 20 inch long side perpendicular to the webs. A half inch steel plate was placed over the pad through which actuator would distribute the load to the panel within a rectangular area of 20 inch $\mathrm{x} 10$ inch. Twenty inch being the equivalent width of a truck-wheel was placed perpendicular to webs. The fatigue loading was applied with a loading frequency of $3 \mathrm{~Hz}$ and maximum and minimum load range of $23 \mathrm{klbs}$ and $4 \mathrm{klbs}$ respectively. Dial gages were placed at the center to measure deformation/deflections of the cells under $23 \mathrm{klbs}$ of static loading and strain gages were used to measure the strains.

\subsection{Scanning Electron Microscopy}

Coupon specimens were prepared to examine under scanning electron microscope. SEM images were taken in order to evaluate the interface that exists between fibers and matrix, the orientation of fibers in the composite and the presence of air voids. Adequate adhesion between the fibers and matrix is necessary for an optimized stress transfer in fiber reinforced polymer (FRP). Surface treatment improves the fiber-matrix adhesion by modifying the structure and the chemical composition of the fiber surface. 


\subsubsection{Specimen Preparation}

Steps in SEM sample preparation consisted of the following:

I. Since the dimension of sample for SEM study is limited by the Microscopy equipment, cubical shape sample of size 0.25 " was cut from the composite plate for SEM study.

II. Epoxy was used to mold these specimens in cylindrical rubber mold with epoxy. Ratio of epoxy to converter was 5:1. Composite sample was first placed in cylindrical mold and epoxy was poured on it. Care was taken to remove air bubbles below the sample surface, in order to avoid any sample damage during grinding step. Mold was allowed to cure for $24 \mathrm{hrs}$.

III. These cylinders with the SEM specimens were fixed on rotating circular disc for grinding purpose. These discs were connected to rotating shaft with motor. Out of the two rotating discs, top one holds epoxy sample and the bottom disc allows mounting of different sand paper on it. Sand papers with grit number of 180, 240, 320,400 and 600 were used in series of steps to achieve smooth specimen surface. The higher the grit number, the smoother is the surface of sand paper. Each grinding step was carried out for about 30 minutes.

IV. Final surface finishing included grinding of the test specimen surface on a white cloth by replacing sand papers. Silica solution was continuously sprayed on the white cloth mounted on bottom disc. Silica solution with different particle size $1 \mu \mathrm{m}, 0.3 \mu \mathrm{m}$ and $0.05 \mu \mathrm{m}$, was used for this purpose.

V. The test specimen was then cleaned with water and epoxy cover was removed by crushing in jaws. Sample were kept away from any damage while crushing the epoxy cylinders

VI. The specimen was then kept in a vacuum chamber and top surface was sputtered with gold particles. Then, the sample was taken out of the vacuum chamber and a conducting cupper tape was mounted on it to avoid the formation of electron cloud while examining under electron microscope.

VII. This test specimen was examined under SEM machine for viewing. 


\subsubsection{Test Set up and Test Procedure}

To evaluate fine structure of fiber-matrix interface and void content, high resolution Electron microscopy (Figure 4.11) was used.

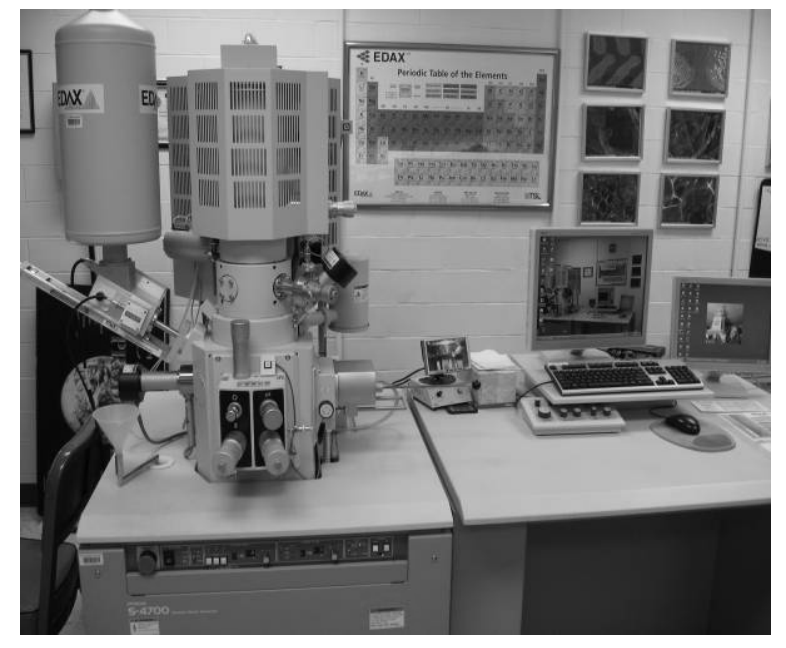

Figure 4.11 Hitachi S-4700 field emission scanning electron microscope (FE-SEM)

(Bambal, 2007)

A Cold Field Emission Gun Scanning Electron Microscope (FEGSEM) with "below-thelens" design was used while examining the composite specimens. FEGSEM is capable of $1.5 \mathrm{~nm}$ resolution at $15 \mathrm{kV}, 12 \mathrm{~mm}$ W.D.; and $2.5 \mathrm{~nm}$ resolution at $1 \mathrm{k}, 2.5 \mathrm{~mm}$ W.D. Magnification ranges from $30 \mathrm{X}$ to $500,000 \mathrm{X}$. Electron source is a cold FE gun producing high brightness $\left(\sim 2 \times 10^{9} \mathrm{~A} / \mathrm{cm}^{2} / \mathrm{sr}\right)$ with little energy spread $(0.2-0.3 \mathrm{eV})$. The "below-the-lens" design and large sample chamber port permits specimens as large as $100 \mathrm{~mm}$ diameter X $17 \mathrm{~mm}$ thick. Secondary and backscattered electron images are the available image modes. There are two secondary electron detectors; one above the objective lens, the other below. Digital images may be acquired in BMP, TIFF, or JPEG file formats at $640 \times 480,1280 \times 960$, or 1560 X 1920 pixels.

Summary: In this chapter, the test methodology and specimen preparation and testing procedure used for mechanical data characterization of composites are discussed. In chapter 5, we will present and discuss results of the tests conducted at coupon and component level on modular FRP pavement panels. 


\section{CHAPTER 5 EXPERIMENTAL RESULTS}

\subsection{Introduction}

The results and discussions of various experiments on panels and their coupons designed and produced at different phases of this research are presented here. Experimental results are divided into two parts- Section 5.2 includes results of tests that were conducted in the WVU laboratory for optimizing HT-VARIM process parameters such as temperature, pressure and amount of MEKP. Section 5.3 Includes experiments carried out on the full size FRP modular panel produced by Fiber-Tech Inc. using HT-VARIM. The test results mentioned in this chapter are organized as follows:

Section 5.2 Optimization of process parameters of HT-VARIM

Section 5.2.1 Curing time of vinyl ester resin for varying catalyst percentage

Section 5.2.2 Tests on coupon specimens

Section 5.2.3 SEM pictures of coupons and interpretations Section 5.3 Experimental results of Panels

Section 5.3.1 Phase I test panel

Section 5.3.1.1 Burn out test on coupons

Section 5.3.1.2 Tension test results of coupons

Section 5.3.1.3 Bending test results of coupons

Section 5.3.1.4 Short beam shear test of coupons

Section 5.3.1.5 Three point bending test on panel

Section 5.3.1.6 SEM pictures of specimens cut from panel

Section 5.3.2 Phase II test panel

Section 5.3.2.1 Burn out test on coupons

Section 5.3.2.2 Tension test results of coupons

Section 5.3.2.3 Bending test results of coupons

Section 5.3.2.4 Short beam shear test of coupons

Section 5.3.2.5 Three point bending and fatigue test on panel

Section 5.3.3 Test panel produced during mass production of actual panel

Section 5.3.3.1 Burn out test on coupons 
Section 5.3.3.2 Tension test results of coupons

Section 5.3.3.3 Bending test results of coupons

Section 5.3.3.4 Short beam shear test of coupons

Section 5.3.3.5 Three point bending and fatigue test on panel

Section 5.3.3.6 Patch loading with two feet span

Section 5.3.4 Properties of actual mass produced panel

\subsection{Optimization of Process Parameters of HT-VARIM}

Influence of amount of MEKP mixed with vinyl ester resin and on bed curing temperature in HT-VARIM on the mechanical properties of composites was investigated (Table 5.1). We conducted preliminary four point bending tests on coupon specimens to evaluate their mechanical properties and those specimens were examined under SEM. Neat vinyl ester resin specimens were tested to relate the variation of curing time with percentage of MEKP.

\subsubsection{Curing Time of Vinyl Ester Resin for Varying Catalyst Percentage}

Initial resin hardening time is defined as the duration from mixing of MEKP with the vinyl ester resin (VER) to the point when application of the resin on the fabric using a brush is not possible. The variation of curing time of VER with the change of MEKP (\%) by weight is shown in Figure 5.1:

Table 5.1 Variation of curing time of VER with the change of MEKP (\%)

\begin{tabular}{|c|c|c|c|}
\hline Resin (gm) & $\begin{array}{c}\text { Cobalt(\%) by } \\
\text { weight }\end{array}$ & $\begin{array}{c}\text { MEKP (\%) by } \\
\text { weight }\end{array}$ & $\begin{array}{c}\text { Initial resin } \\
\text { hardening time } \\
\text { (minutes) }\end{array}$ \\
\hline 130 & 0.2 & 1 & 24 \\
\hline 130 & 0.2 & 1.5 & 16 \\
\hline 130 & 0.2 & 2 & 12 \\
\hline 130 & 0.2 & 3 & 8 \\
\hline
\end{tabular}




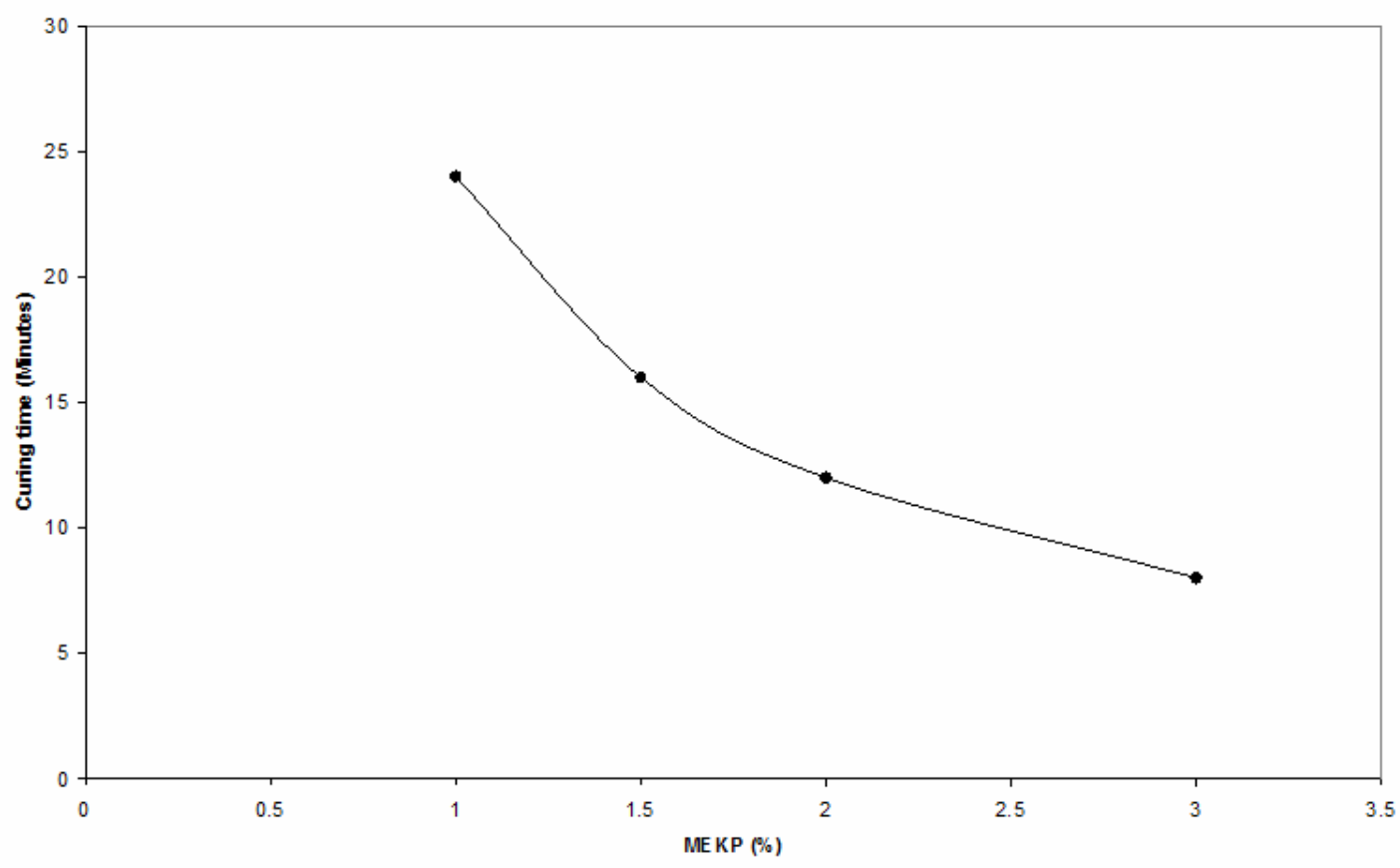

Figure 5.1 Variation of curing time of VER with the change of MEKP (\%)

\subsubsection{Tests on Coupon Specimens}

FRP composite plates were manufactured at different on-bed curing temperatures and amount of MEKP, keeping the attainable vacuum pressure of 24 in $\mathrm{Hg}$ constant and coupon specimens were cut from the plates. Bending and SEM specimens were cut from those plates. Under the scanning electron microscope, (a) Resin and Fiber integration (b) Presence of void (c) Fiber orientation were observed.

\subsubsection{Bending Test Results and Discussions of Coupon Specimens}

Test specimens were divided into 8 groups as shown in Table 5.2. 
Table 5.2 Bending test specimen dimension and manufacturing details:

\begin{tabular}{|c|c|c|c|c|c|c|c|c|c|}
\hline $\begin{array}{l}\text { Sample } \\
\text { ID }\end{array}$ & Fiber Architecture & $\begin{array}{l}\text { Gage } \\
\text { Length } \\
\text { (in) }\end{array}$ & $\begin{array}{l}\text { Average } \\
\text { Width } \\
\text { (in) }\end{array}$ & $\begin{array}{l}\text { Average } \\
\text { Thickness } \\
\text { (in) }\end{array}$ & $\begin{array}{l}\text { Average } \\
\text { FVF (\%) }\end{array}$ & $\begin{array}{l}\text { Heating } \\
\text { temperature }\end{array}$ & $\begin{array}{l}\text { Amount } \\
\text { of } \\
\text { MEKP } \\
(\%)\end{array}$ & $\begin{array}{l}\text { Heat- } \\
\text { ng } \\
\text { time } \\
\text { (min) }\end{array}$ & $\begin{array}{l}\text { Vacuum } \\
\text { Pressure } \\
\text { (in of } \\
\mathrm{Hg} \text { ) }\end{array}$ \\
\hline $\mathrm{BG}_{1} \mathrm{O}$ & \multirow{8}{*}{$\begin{array}{l}0-90-\mathrm{CSM} \\
7 \text { Layers } \\
\left(0-5.8 \mathrm{oz} / \mathrm{yd}^{2}\right. \\
90-6 \mathrm{oz} / \mathrm{yd}^{2} \\
\text { CSM-7.6 oz/yd }{ }^{2)}\end{array}$} & 6 & 0.975 & 0.234 & 42 & $\operatorname{Room}\left(93^{0} \mathrm{~F}\right)$ & 1.5 & 30 & 24 \\
\hline $\mathrm{BG}_{2} \mathrm{O}$ & & 6 & 1 & 0.230 & 42 & $\operatorname{Room}\left(93^{0} \mathrm{~F}\right)$ & 2 & 30 & 24 \\
\hline $\mathrm{BG}_{3} \mathrm{O}$ & & 6 & 1 & 0.231 & 42 & $120^{0} \mathrm{~F}$ & 1.5 & 30 & 24 \\
\hline $\mathrm{BG}_{4} \mathrm{O}$ & & 6 & 0.998 & 0.233 & 42 & $120^{0} \mathrm{~F}$ & 2 & 30 & 24 \\
\hline $\mathrm{BG}_{5} \mathrm{O}$ & & 6 & 0.976 & 0.231 & 42 & $150^{0} \mathrm{~F}$ & 1.5 & 30 & 24 \\
\hline $\mathrm{BG}_{6} \mathrm{O}$ & & 6 & 1 & 0.230 & 42 & $150^{\circ} \mathrm{F}$ & 2 & 30 & 24 \\
\hline $\mathrm{BG}_{7} \mathrm{O}$ & & 6 & 1 & 0.234 & 42 & $200^{0} \mathrm{~F}$ & 1.5 & 30 & 24 \\
\hline $\mathrm{BG}_{8} \mathrm{O}$ & & & 1 & 0.230 & 42 & $200^{0} \mathrm{~F}$ & 2 & 30 & 24 \\
\hline
\end{tabular}

B: Bending Test Specimens, $\mathbf{G}_{\mathbf{n}}$ : Group n (where, $\mathrm{n}=1,2, \ldots \ldots 8$ ) specimens,

O: Specimens used for the process parameters optimizations 
Four specimens of each group were tested under bending and average values are displayed in the Table 5.3. Bending Modulus and Maximum Bending stress are represented in Figures 5.4 and Figures 5.5 respectively.

Table 5.3 Bending test Results

\begin{tabular}{|c|c|c|c|c|c|c|}
\hline Sample ID & Lay Up & $\begin{array}{l}\text { Average FVF } \\
(\%)\end{array}$ & $\begin{array}{l}\text { Av. FVF(\%) in } \\
\text { loading } \\
\text { direction }\end{array}$ & $\begin{array}{l}\text { Bending } \\
\text { Modulus (msi) }\end{array}$ & $\begin{array}{l}\text { Maximum } \\
\text { Bending Stress } \\
\text { (ksi) }\end{array}$ & \begin{tabular}{|l} 
Normalized \\
Bending Stress \\
(ksi)
\end{tabular} \\
\hline $\mathrm{BG}_{1} \mathrm{O}$ & \multirow{8}{*}{$\begin{array}{l}0-90-\mathrm{CSM} \\
7 \text { Layers } \\
\left(0-5.8 \mathrm{oz} / \mathrm{yd}^{2}\right.\end{array}$} & \multirow{8}{*}{$42 \%$} & \multirow{8}{*}{$18.7 \%$} & 1.27 & 20.7 & 111 \\
\hline $\mathrm{BG}_{2} \mathrm{O}$ & & & & 1.53 & 28.0 & 150 \\
\hline $\mathrm{BG}_{3} \mathrm{O}$ & & & & 1.76 & 28.2 & 151 \\
\hline $\mathrm{BG}_{4} \mathrm{O}$ & & & & 1.86 & 35.3 & 189 \\
\hline $\mathrm{BG}_{5} \mathrm{O}$ & & & & 2.15 & 39.3 & 210 \\
\hline $\mathrm{BG}_{6} \mathrm{O}$ & & & & 1.66 & 36.7 & 197 \\
\hline $\mathrm{BG}_{7} \mathrm{O}$ & & & & 1.61 & 30.0 & 160 \\
\hline $\mathrm{BG}_{8} \mathrm{O}$ & & & & 1.73 & 23.0 & 123 \\
\hline
\end{tabular}

*Normalized bending stress is defined as the ultimate bending stress divided by the average FVF in loading direction As an example, a coupon sample with a Quadri-axial fabric layout (0- $6 \mathrm{oz} / \mathrm{yd}^{2}, 90-6 \mathrm{oz} / \mathrm{yd}^{2}, 45-4 \mathrm{oz} / \mathrm{yd}^{2}$ and $\left.-45-4 \mathrm{oz} / \mathrm{yd}^{2}\right)$ and Fiber Volume Fraction of $50 \%$ has ultimate stress of $27 \mathrm{ksi}$. The Effective Fiber Volume Fraction is: $\frac{6+0+4 \times \cos ^{2} 45+4 \times \sin ^{2} 45}{6+6+4+4} \times 50=25 \%$

Normalized Stress is calculated as: $27 / 0.25=108 \mathrm{ksi}$ 


\section{Discussion of test results:}

From bending tests on coupon specimens cut from the plates manufactured by HTVARIM with a varying curing temperature, percentage of catalyst mixed with resin and the specific fiber architecture mentioned in Table 5.3, following observations were made. However, an extensive research must be carried out in order to draw a generic inference from the observations of these experiments.

I. Specimens cured at $200^{\circ} \mathrm{F}$ showed brittle failures under the four point bending load. Figure 5.2 shows a typical load-deflection curve of a specimen cured at $200^{\circ} \mathrm{F}$ with $2 \%$ catalyst (by weight) exhibiting sudden failure at 210 lbs characterizing by an increase in deflection without increase in load. This behavior is attributed to quick curing and increase in resin viscosity (hardening) with high temperature and amount of catalyst. Figure 5.2 shows more ductile failure pattern of a sample cured at $150^{\circ} \mathrm{F}$ with $1.5 \%$ catalyst (by weight) than the one cured at $200^{\circ} \mathrm{F}$ with $2.0 \%$ catalyst (by weight).

II. Figures 5.3, 5.4 and 5.5 represent average normalized ultimate bending stress, bending modulus and average ultimate bending stress of specimens manufactured at different resin curing temperatures with different percentage. Heating and vacuum pressure were constant for 30 minutes and 24 in $\mathrm{Hg}$, respectively. Preliminary study indicates that the composites manufactured with $1.5 \%$ catalyst weight and curing temperature of $150^{\circ} \mathrm{F}$ provided superior strength and stiffness properties to other temperature and catalyst percentage.

III. With simultaneous heating of specimens and suctioning pressure of air, low void formation in the composite was observed. When we examined the specimens under the SEM, the composites cured at $150^{\circ} \mathrm{F}$ exhibited comparatively low voids. Beyond $150^{\circ} \mathrm{F}$, due increased rate of curing inadequate fiber wetting with as resin can not penetrate well into fibers. Therefore, dry fabric locations were observed at micro level in SEM specimens cured at $200^{\circ} \mathrm{F}$.

IV. Many voids in the composites cured at room temperature and $120^{\circ} \mathrm{F}$ were observed. Specimens cured at room temperature with $1.5 \%$ catalyst by weight, showed inadequate curing of vinyl ester resin and lower bending properties. 


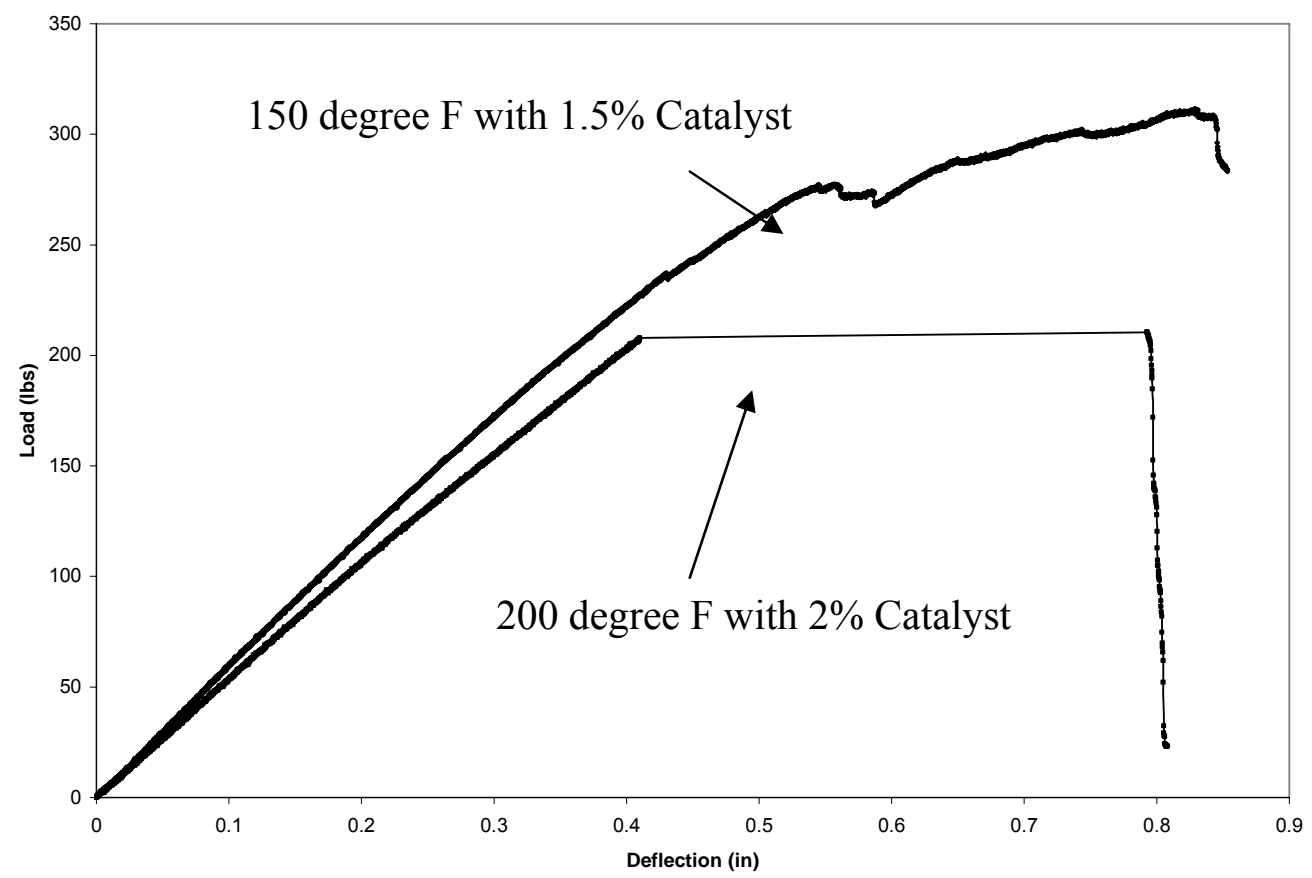

Figure 5.2 Load-deflection of specimens cured at $150^{\circ} \mathrm{F}$ with $1.5 \%$ catalyst and $200^{\circ}$ F and $2 \%$ weight catalyst

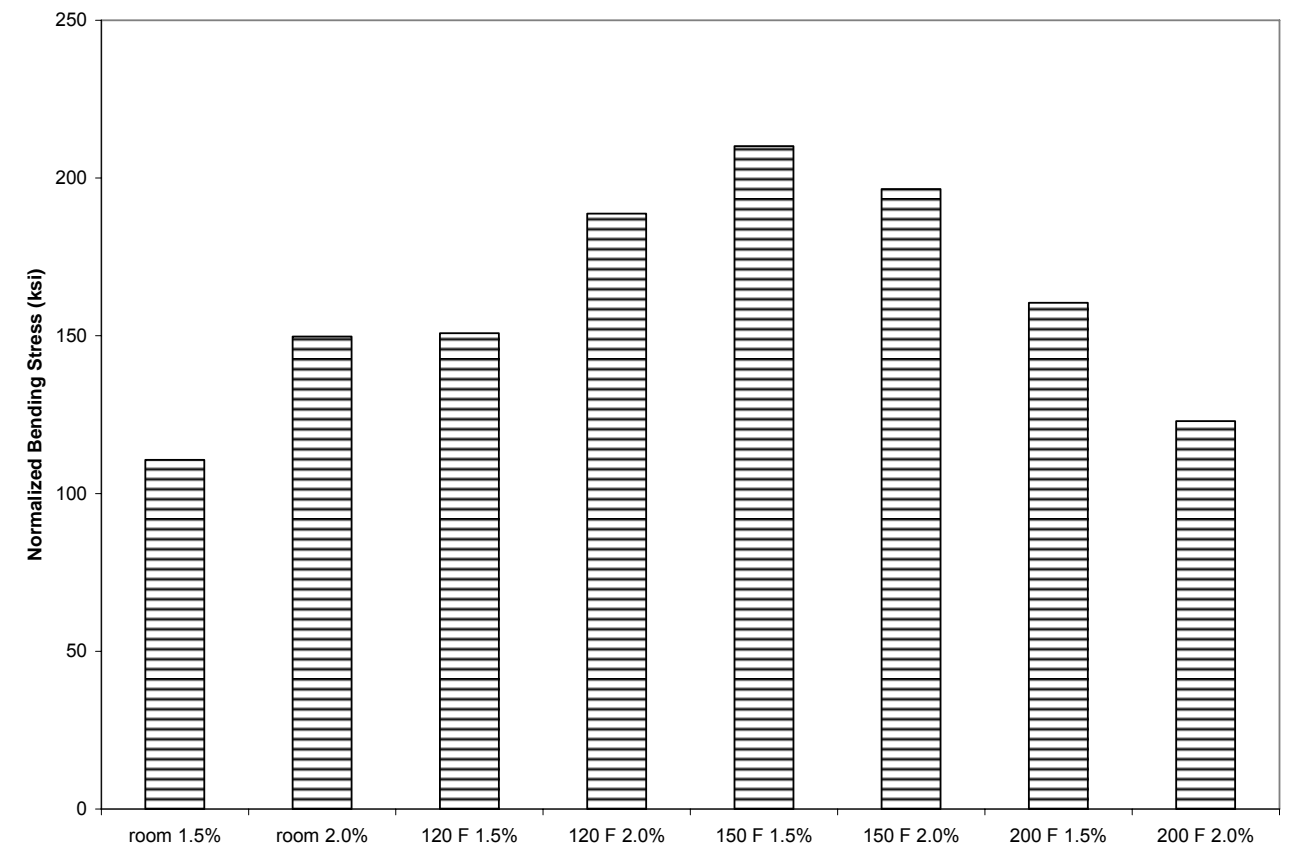

Figure 5.3 Variation of normalized stress for different cure temperature and varying MEKP 


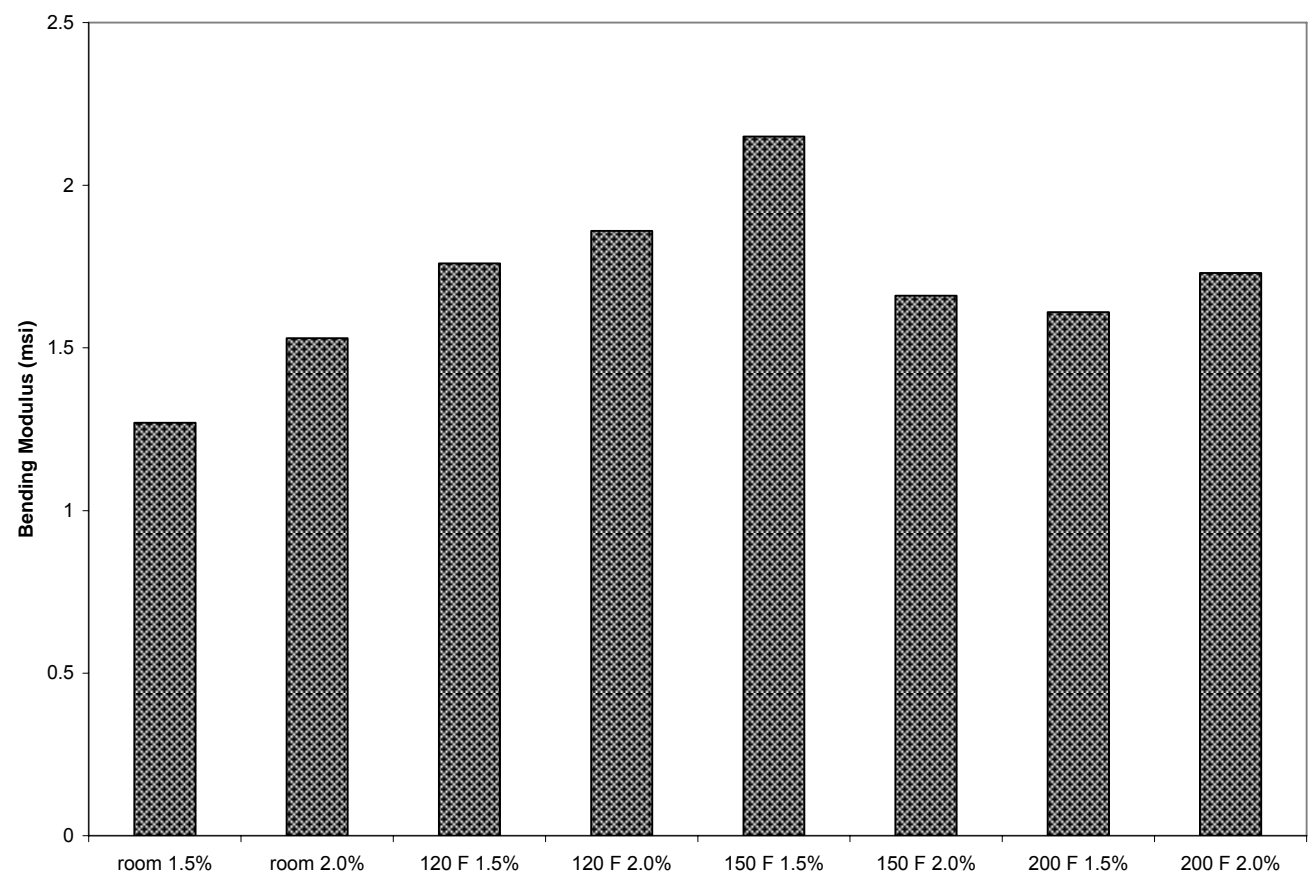

Figure 5.4 Average bending modulus variation for different cure temperature and varying MEKP

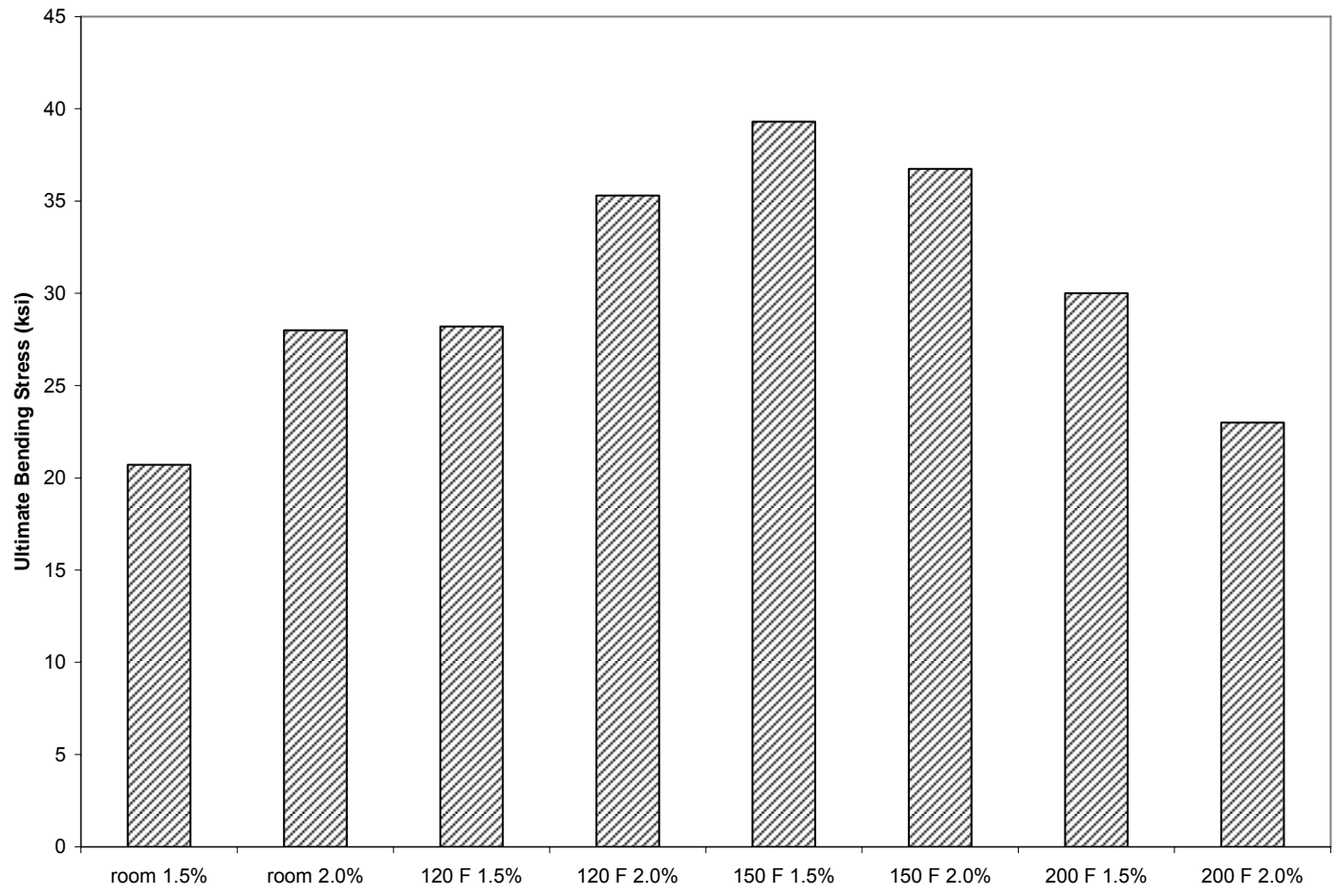

Figure 5.5 Maximum bending stress variation for different cure temperatures and $\%$ catalyst (MEKP) 


\subsubsection{SEM Pictures and Interpretations}

Figure 5.6 shows the SEM image of specimens cured at room temperature. These pictures represent typical circular interfacial air gaps/pockets which were observed at room temperature cure with $1.5 \%$ and $2 \%$ MEKP by weight. Though the distribution of resin within the fabrics was quite uniform without localized accumulations, presence of air gaps and lack of resin-fiber bond (Figures 5.6 and 5.7) resulted in a reduction of composite mechanical properties (Table 5.3 and Figures 5.5 and 5.6).
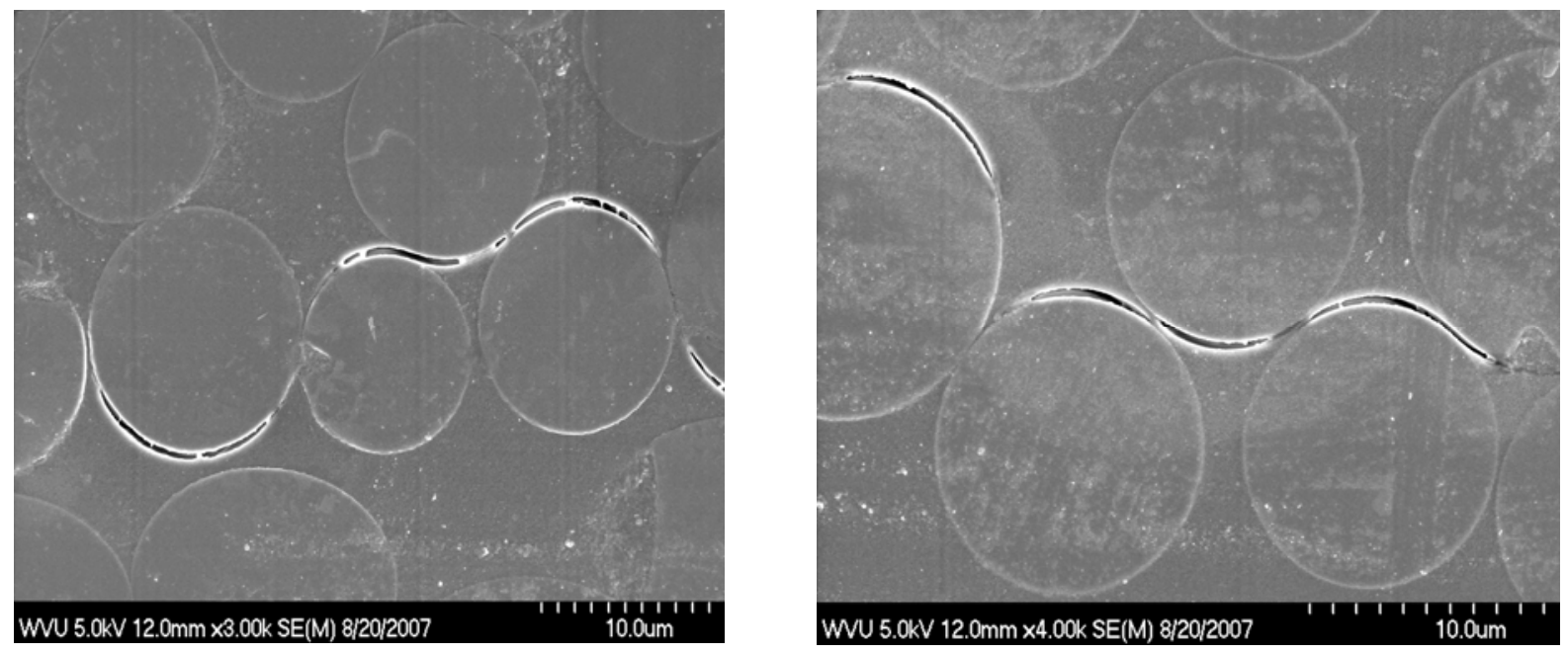

Figure 5.6 Predominant air pockets for specimens cured at room temperature $\left(\sim 93^{0}\right.$ F) with $1.5 \%$ and $2 \%$ catalyst

SEM evaluation also indicated the formation of a continuous air gap formed by the joining the three to four entrapped air gaps around the fiber circumference during vacuum assisted curing. SEM of composite specimens (Figure 5.7) cured at $120^{\circ} \mathrm{F}$ showed smaller size air pockets compared to those cured at room temperature. Increase in curing temperature assisted by simultaneous vacuum pressure resulted in decreased air entrapment, uniform fiber wet out and better mechanical properties of the composite. 


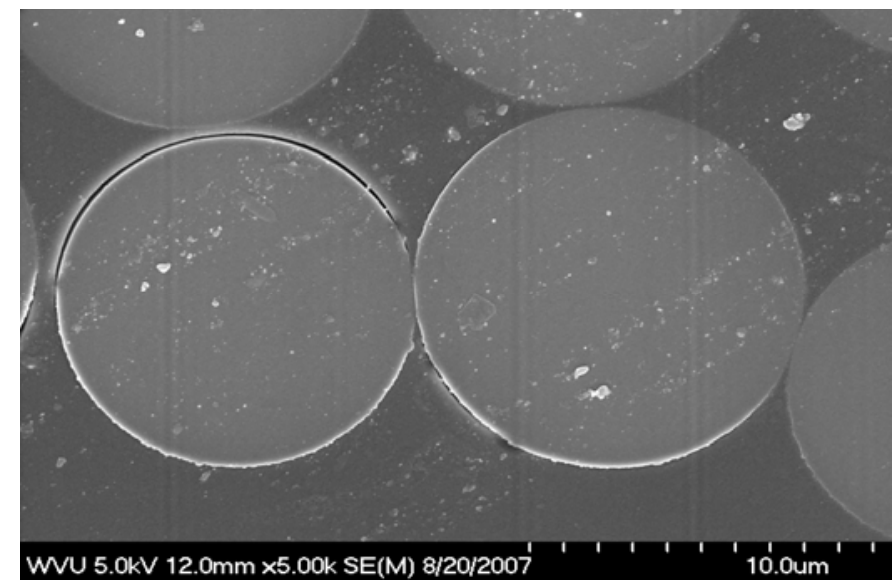

Figure 5.7 Reduction in air pocket for specimens cured at $120^{0} \mathrm{~F}$ (Vs. room temperature)
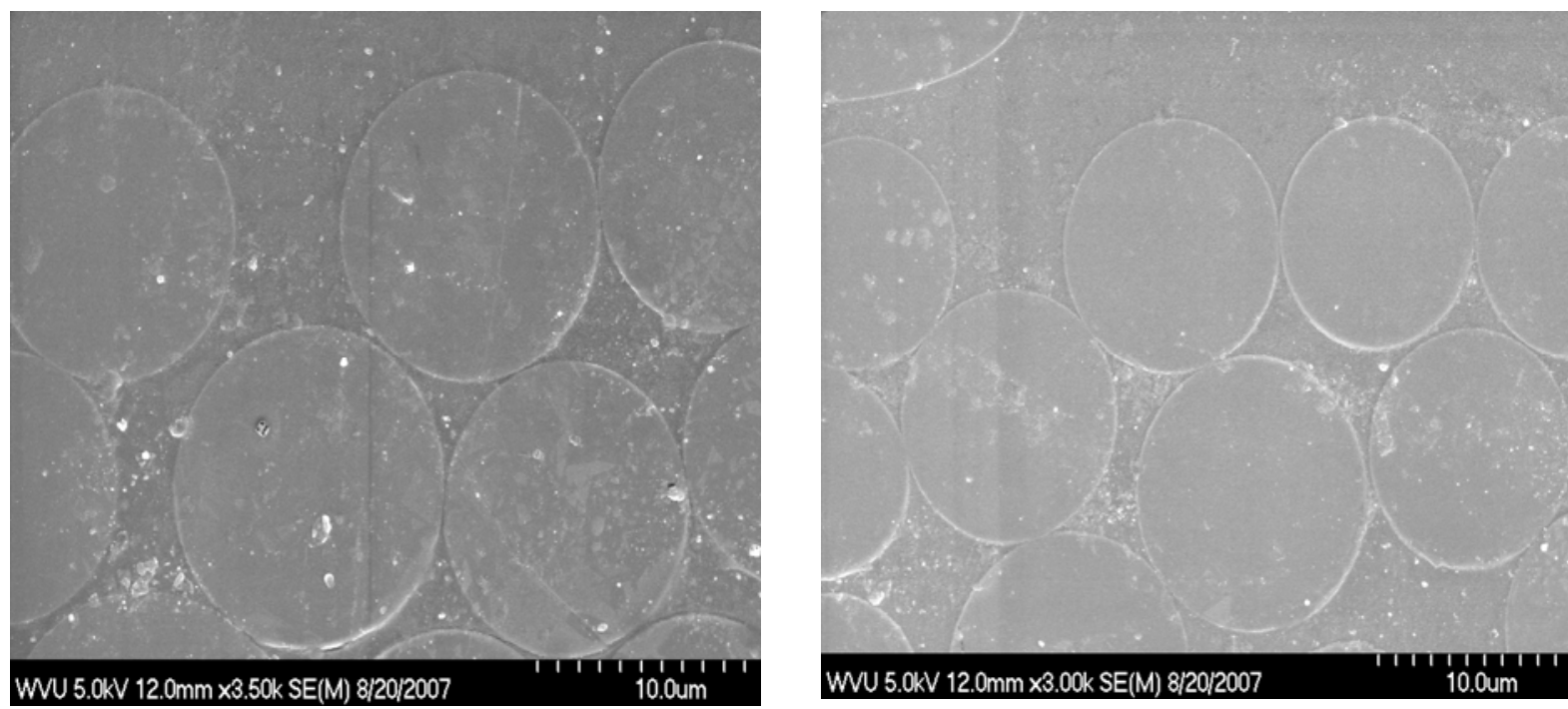

Figure 5.8 Fiber orientation of specimens cured at $150^{\circ} \mathrm{F}$

SEM of specimens (Figure 5.8) prepared with 1.5\% and 2\% MEKP (by weight) and cured at $150^{\circ} \mathrm{F}$ temperatures showed uniform resin infusion and absence of any airpockets including better mechanical properties (Table 5.3). 


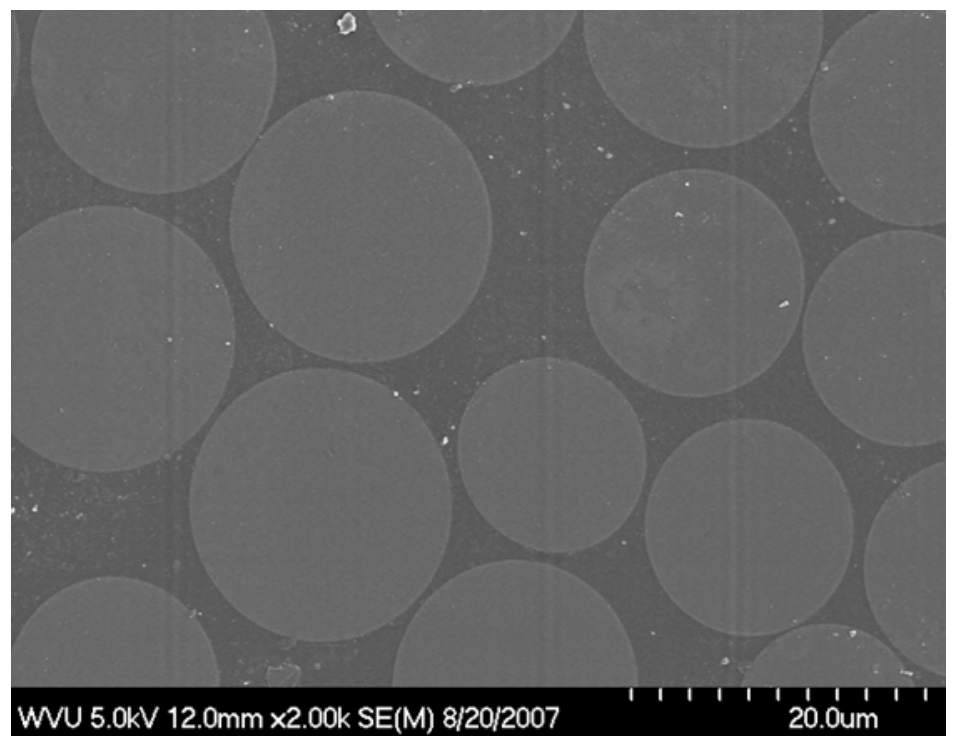

Figure 5.9 Fiber orientation of specimens cured at $150^{\circ} \mathrm{F}$

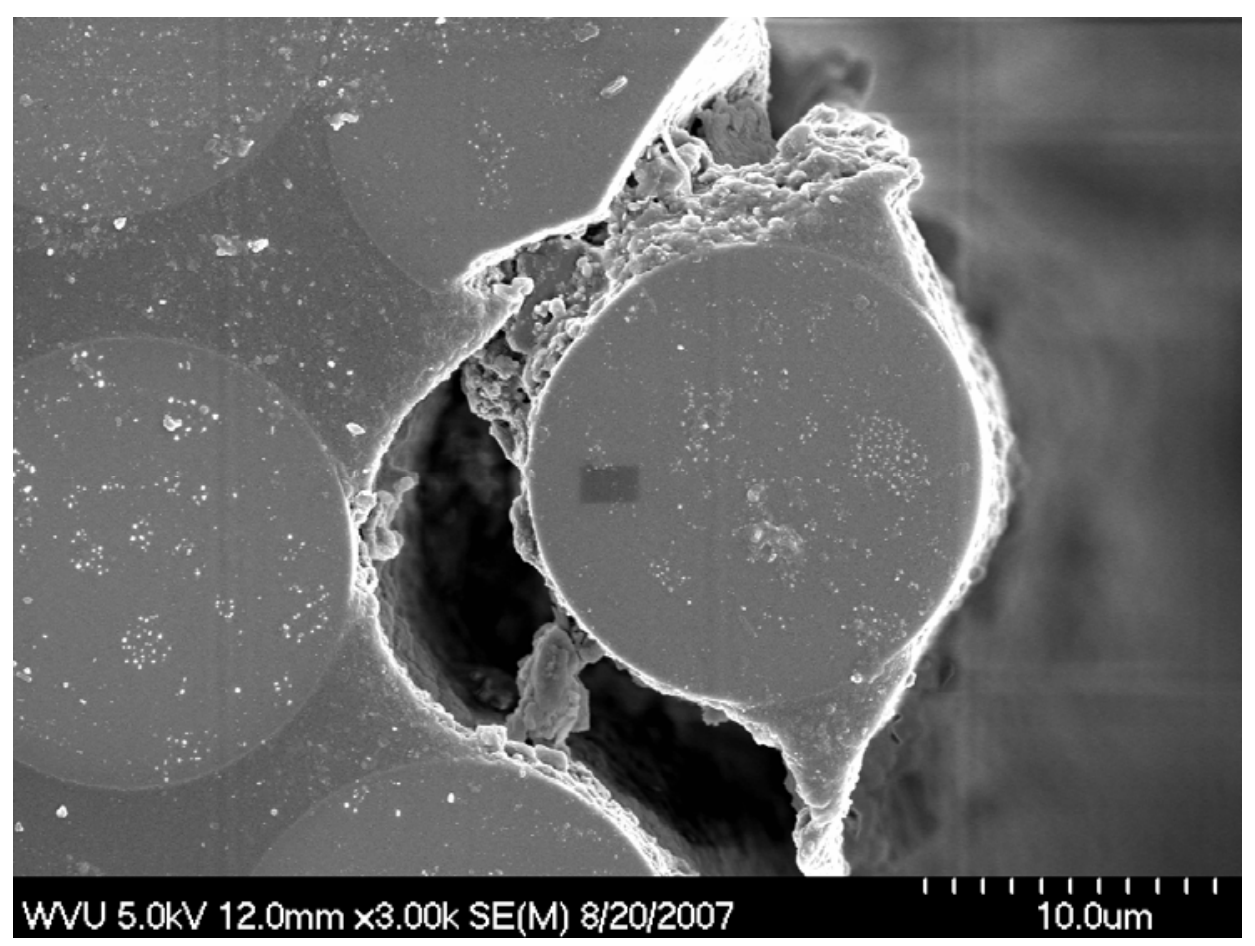

Figure 5.10 Fiber dryness at some places in specimens cured at $200^{\circ} \mathrm{F}$ with $1.5 \%$ catalyst 


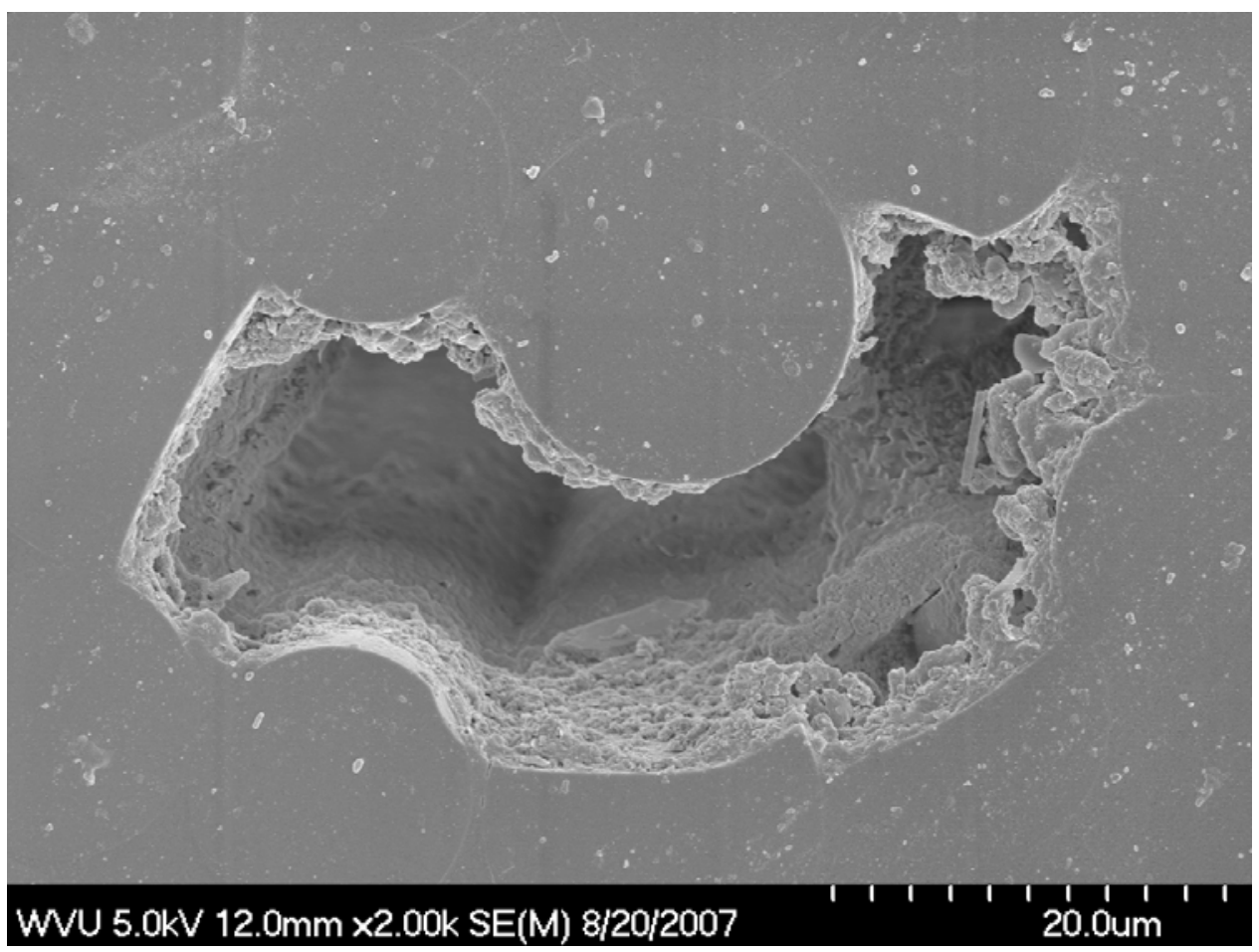

Figure 5.11 Fiber dryness at some places in specimens cured at $200^{\circ} \mathrm{F}$ and $2 \%$ by weight

Figures 5.10 and 5.11 show some large gaps where proper resin infusion did not take place and fiber remained dry at an elevated of $200^{\circ} \mathrm{F}$ due to faster cure rate. These nonuniformly resin locations and gaps corresponding to resin flow were more widely observed in the specimens with $2 \%$ MEKP (by weight) and cured at $200^{\circ} \mathrm{F}$. The effect of curing temperature and MEKP percentage added to resin, on air entrapment and void generation must be further studied by evaluating more numbers of specimens cut from different locations of a single plate manufactured by HT-VARIM.

\subsection{Experimental Results of Panels Manufactured by Fiber-Tech Inc.}

\subsubsection{Phase I Test Panels}

Two test panels were produced by Fiber-Tech Inc. with the fabric specification as mentioned earlier in chapter 3. The infusion of resin was done at $150^{\circ} \mathrm{F}$ and $24 \mathrm{in} \mathrm{Hg}$ vacuum pressure. Specimens were cut from the web and flange of the panels for carrying out burn out, tension, bending and short beam shear tests. Specimens were also extracted (cut-out) from flanges and webs at various locations for conducting SEM. It is worth 
mentioning here that, while extracting (cutting) the specimens from the flange, sagging part of the flange was avoided.

\subsubsection{Burn out Test and Discussion}

Burns out test results are provided in Table 5.4.

Table 5.4 Burn out test results

\begin{tabular}{|l|l|l|l|l|l|l|l|l|l|}
\hline $\begin{array}{l}\text { Sample } \\
\text { No }\end{array}$ & $\begin{array}{l}\text { Length } \\
\text { (in) }\end{array}$ & $\begin{array}{l}\text { Breadth } \\
\text { (in) }\end{array}$ & $\begin{array}{l}\text { Thickness } \\
\text { (in) }\end{array}$ & $\begin{array}{l}\mathbf{W}_{\mathbf{C}+\mathbf{S}} \\
(\mathbf{g m})\end{array}$ & $\begin{array}{l}\mathbf{W}_{\mathbf{S}} \\
\mathbf{( g m )}\end{array}$ & $\begin{array}{l}\mathbf{W}_{\mathbf{C}} \\
(\mathbf{g m})\end{array}$ & $\begin{array}{l}\mathbf{W}_{\mathbf{f}+\mathbf{C}} \\
\mathbf{( g m}) \\
(\mathbf{b u r n})\end{array}$ & $\begin{array}{l}\mathbf{L B T} \\
\mathbf{( C C )}\end{array}$ & $\begin{array}{l}\mathbf{F V F} \\
\mathbf{( \% )}\end{array}$ \\
\hline $\mathbf{W}_{\mathbf{1}}$ & 1.021 & 1.03 & 0.35 & 31.2 & 11.5 & 19.7 & 27.6 & 6.031595 & 52 \\
\hline $\mathbf{W}_{\mathbf{2}}$ & 1.000 & 1.00 & 0.34 & 29.7 & 11.1 & 18.6 & 26.3 & 5.934786 & 51 \\
\hline $\mathbf{W}_{\mathbf{3}}$ & 1.007 & 1.031 & 0.35 & 31.2 & 11.2 & 20.0 & 27.6 & 5.954665 & 51 \\
\hline $\mathbf{F}_{\mathbf{1}}$ & 1.011 & 1.015 & 0.49 & 36.3 & 16.1 & 20.2 & 30.8 & 8.239400 & 49 \\
\hline $\mathbf{F}_{\mathbf{2}}$ & 1.015 & 1.015 & 0.45 & 36.2 & 16.5 & 19.7 & 29.7 & 7.603598 & 52 \\
\hline $\mathbf{F}_{\mathbf{3}}$ & 1.002 & 1.015 & 0.45 & 35.1 & 15.9 & 20.0 & 29.4 & 7.499761 & 53 \\
\hline
\end{tabular}

Density of Fabric: $2.522 \mathrm{gm} / \mathrm{cc}$

$\mathrm{W}_{\mathrm{n}}=$ Web specimen number $\mathrm{n}$, where $\mathrm{n}=1,2, \ldots \ldots$

$\mathrm{F}_{\mathrm{n}}=$ Flange specimen number $\mathrm{n}$, where $\mathrm{n}=1,2, \ldots$

$\mathrm{W}_{\mathrm{C}}=$ Weight of empty crucible (in gms)

$\mathrm{W}_{\mathrm{c}+\mathrm{s}}=$ Weight of crucible + sample (in gms) before burn-out

$\mathrm{W}_{\mathrm{f}+\mathrm{c}}=$ Weight of fabric (left after resin burn) + crucible (in gms) after burn-out

\section{Discussion of test results}

Burn out test results indicates that Fiber Volume Fraction was similar in both the flanges and the webs (table 5.4). Infusion took place uniformly at the places we cut the specimens. These specimens were cut from the locations with uniform resin infusion by avoiding sagged part of the flange with resin accumulation. Unlike flange, resin infusion was noted to be uniform in the web.

\subsubsection{Tension Test Results of Coupons}

Ultimate tensile strength and tensile modulus are evaluated on the basis of the test results. Tension test results are presented in Table 5.5. 
Table 5.5 Tension test results of coupons

\begin{tabular}{|c|c|c|c|c|c|c|c|c|c|c|c|}
\hline $\begin{array}{c}\text { Sample } \\
\text { No }\end{array}$ & $\begin{array}{c}\text { Average } \\
\text { FVF } \\
(\%)\end{array}$ & $\begin{array}{c}\text { Average } \\
\text { FVF(\%) } \\
\text { in loading } \\
\text { direction }\end{array}$ & $\begin{array}{c}\text { Gage } \\
\text { Length } \\
\text { (in) }\end{array}$ & $\begin{array}{c}\text { Tab } \\
\text { Length } \\
\text { (in) }\end{array}$ & $\begin{array}{l}\text { Thickness } \\
\text { (in) }\end{array}$ & $\begin{array}{c}\text { Width } \\
\text { (in) }\end{array}$ & $\begin{array}{c}\text { Ultimate } \\
\text { Stress } \\
\text { (ksi) }\end{array}$ & $\begin{array}{c}\text { Strain } \\
\text { at gage } \\
\text { failure } \\
\text { (micro) }\end{array}$ & $\begin{array}{c}\text { Gage } \\
\text { failure } \\
\text { Stress } \\
\text { (ksi) }\end{array}$ & $\begin{array}{l}\text { Tension } \\
\text { Modulus } \\
\quad(\mathbf{m s i})\end{array}$ & $\begin{array}{c}\text { Normalized* } \\
\text { Tensile } \\
\text { Stress (ksi) }\end{array}$ \\
\hline $\mathbf{T F}_{1} \mathbf{P}$ & \multirow{3}{*}{$51 \%$} & \multirow{3}{*}{$35 \%$} & 10 & 4.5 & 0.50 & 1.002 & 39.9 & 9187 & 39.9 & 4.33 & 114 \\
\hline $\mathbf{T F}_{2} \mathbf{P}$ & & & 10 & 4.5 & 0.50 & 1.001 & 38.10 & 14208 & 38.1 & 3.10 & 109 \\
\hline $\mathbf{T F}_{3} \mathbf{P}$ & & & 10 & 4.5 & 0.51 & 1.001 & 30.00 & 9293 & 30.00 & 3.30 & 86 \\
\hline $\mathbf{T W}_{1} \mathbf{P}$ & \multirow{3}{*}{$51 \%$} & \multirow{3}{*}{$30 \%$} & 10 & 4.5 & 0.36 & 1.001 & 40.40 & 9713 & 26.23 & 2.67 & 135 \\
\hline $\mathbf{T W}_{\mathbf{3}} \mathbf{P}$ & & & 10 & 4.5 & 0.35 & 0.987 & 37.90 & 16267 & 37.9 & 2.41 & 127 \\
\hline $\mathbf{T W}_{3} \mathbf{P}$ & & & 10 & 4.5 & 0.35 & 1.002 & 34.10 & 12985 & 34.1 & 2.69 & 114 \\
\hline
\end{tabular}

*Normalized tensile stress is defined as the Ultimate tensile stress divided by the average FVF in loading direction As an example, a tensile coupon sample with a Quadri-axial fabric layout (0-6 oz/yd ${ }^{2}, 90-6 \mathrm{oz} / \mathrm{yd}^{2}, 45-4 \mathrm{oz} / \mathrm{yd}^{2}$ and $\left.-45-4 \mathrm{oz} / \mathrm{yd}^{2}\right)$ and Fiber Volume Fraction of $50 \%$ has ultimate stress of $27 \mathrm{ksi}$. The Effective Fiber Volume Fraction is: $\frac{6+0+4 \times \cos ^{2} 45+4 \times \sin ^{2} 45}{6+6+4+4} \times 50=25 \%$ Normalized Stress is calculated as: $27 / 0.25=108 \mathrm{ksi}$

$\mathrm{TF}_{n} \mathrm{P}=$ Tension specimen number ' $\mathrm{n}$ ' from flange of the panel $\mathrm{TW}_{\mathrm{n}} \mathrm{P}=$ Tension Specimen number ' $\mathrm{n}$ ' from web of the panel 
Stress Vs Strain (Sample TF1P)

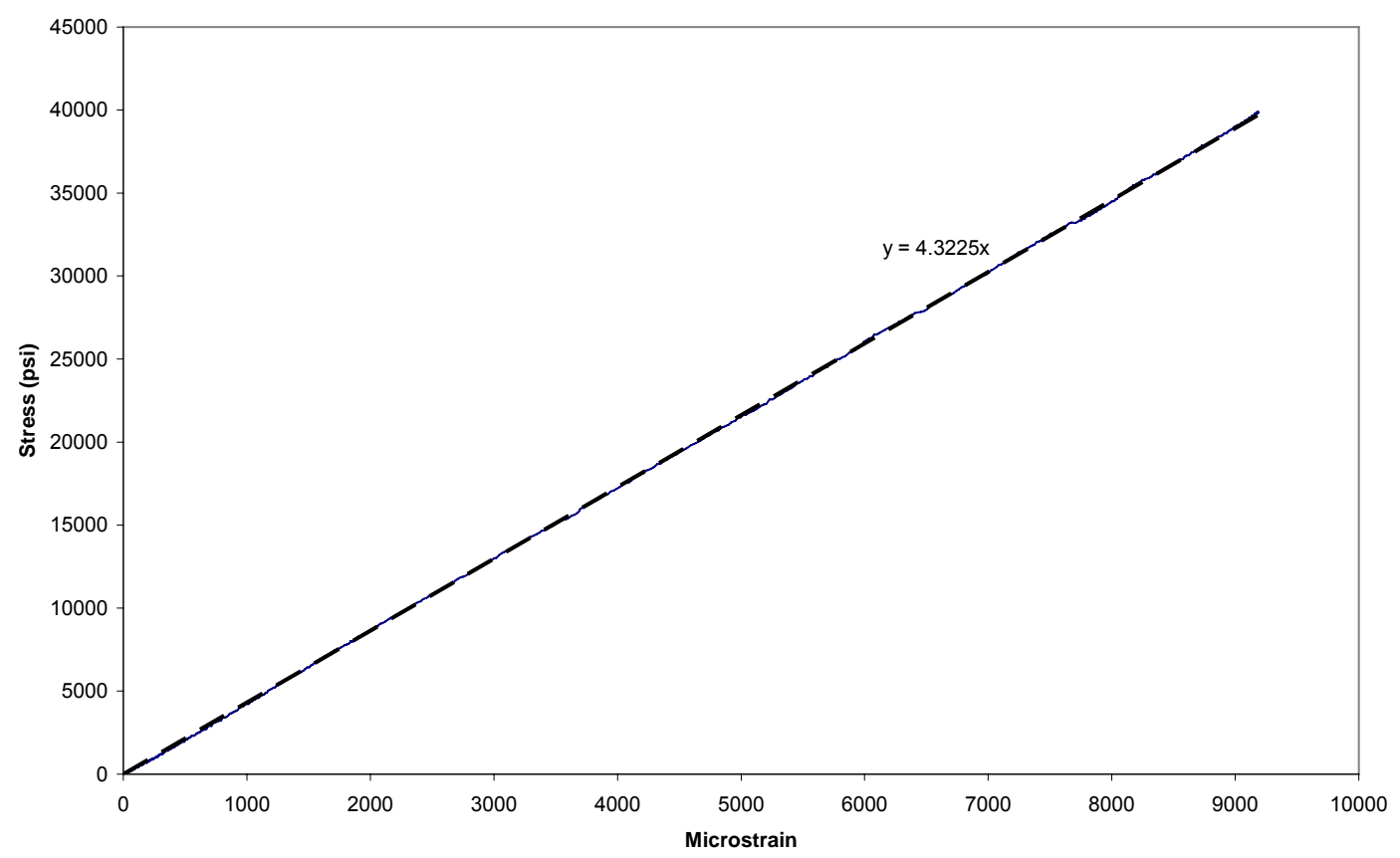

Figure 5.12 Stress Vs strain curve for specimen number $\mathrm{TF}_{1} \mathrm{P}$

\section{Discussion of Test Results:}

The following observations were noted from tension test results conducted on coupons cut from the panel:

I. Average tensile modulus of coupons from the web is $2.6 \mathrm{msi}$. The coupon specimens from webs have an average ultimate tensile stress of about $37.7 \mathrm{ksi}$. The average tensile modulus and ultimate tensile stress of coupons from flange are $3.2 \mathrm{msi}$ and $38 \mathrm{ksi}$ respectively.

II. Figure 5.12 shows a linear variation of tensile stress Vs strain.

III. SEM of tension coupon specimens (Figure 5.13) cut from flanges show oval shaped cross sections of unidirectional fibers. These cross sections indicate off-axis orientation of uni-directional fabrics. 


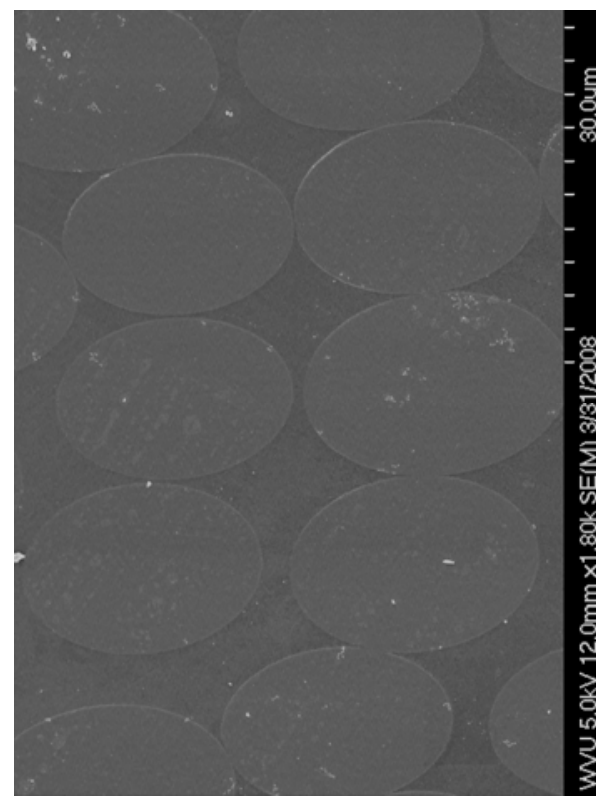

Cross-section of a uni-directional fiber

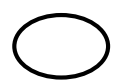

Cross-section of a non uni-directional fiber

\section{Figure 5.13 Typical picture showing misalignment of zero degree fibers}

Though burn out tests of the specimens gave a uniform FVF of $\sim 51 \%$, off-axis orientation of unidirectional fibers reduced the effective FVF in the loading direction and resulted in lower ultimate tensile stress of coupon specimens from those locations. Due to off-axis orientations, specimens from flanges had a large variation in tensile stress values. This variation was less visible in case of specimens from webs since unidirectional fibers in a web were $44 \%$ less than those in the flanges.

IV. Strain gages were installed at the center on one face of the flange and webs coupon specimens. Coupon specimens from flanges had 100 mil cardboard layers attached to on one of the sides whereas; coupon specimens from webs had cardboards attached on both sides. Schematic of coupon specimens is shown in Figure 5.14. 


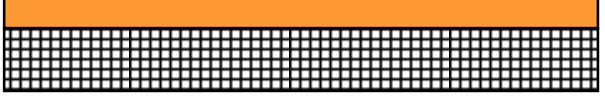

(a)

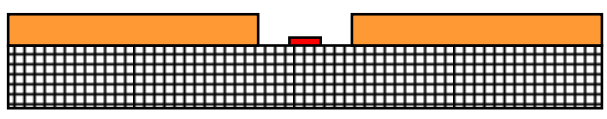

(c)

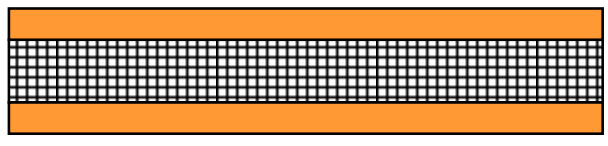

(b)

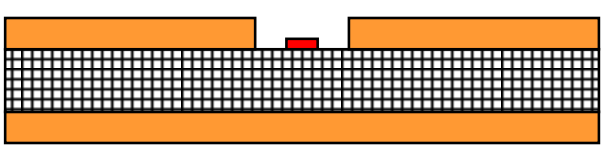

(d)

Cardboard layer

Strain Gage

Figure 5.14 Cardboard attached on tensile specimens: (a) coupon from flange (b) coupon from webs (c) coupon from flange after strain gage attachment (d) Coupon from webs after strain gage attachment.

The cardboard was grinded off at the center of a coupon before preparing the surface for mounting strain gage. Presence of cardboard resulted in additional stiffness and lower strain gage readings.

\subsubsection{Bending Test Results}

Four point bending tests were conducted on the specimens cut from the webs and flanges of the panel. Ultimate stress and bending modulus were evaluated. The results are provided in Table 5.6. 
Table 5.6 Results of bending test

\begin{tabular}{|c|c|c|c|c|c|c|c|c|c|c|c|}
\hline \multirow[b]{2}{*}{$\begin{array}{l}\text { Sample } \\
\text { No }\end{array}$} & \multirow{2}{*}{$\begin{array}{l}\text { Average } \\
\text { FVF } \\
(\%)\end{array}$} & \multirow{2}{*}{$\begin{array}{l}\text { Average } \\
\text { FVF in } \\
\text { loading } \\
\text { direction } \\
(\%)\end{array}$} & \multirow[b]{2}{*}{ Span(in) } & \multirow[b]{2}{*}{ Width(in) } & \multirow[b]{2}{*}{$\begin{array}{l}\text { Thickness } \\
\text { (in) }\end{array}$} & \multirow{2}{*}{$\begin{array}{l}\text { Ultimate } \\
\text { Load } \\
\text { (lbs) }\end{array}$} & \multirow{2}{*}{$\begin{array}{l}\text { Ultimate } \\
\text { Stress } \\
\text { (ksi) }\end{array}$} & \multirow{2}{*}{$\begin{array}{l}\text { Gage } \\
\text { Failure } \\
\text { Strain } \\
\text { (micro) }\end{array}$} & \multirow{2}{*}{$\begin{array}{l}\text { Stress } \\
\text { At } \\
\text { gage } \\
\text { failure } \\
\text { (ksi) }\end{array}$} & \multicolumn{2}{|c|}{$\begin{array}{l}\text { Bending Modulus } \\
\text { (msi) }\end{array}$} \\
\hline & & & & & & & & & & $\begin{array}{l}\text { From } \\
\text { Stress- } \\
\text { Strain }\end{array}$ & $\begin{array}{l}\text { From } \\
\text { Load- } \\
\text { Deflection }\end{array}$ \\
\hline $\mathrm{BF}_{\mathbf{1}} \mathbf{P}$ & \multirow{3}{*}{$51 \%$} & \multirow{3}{*}{$35 \%$} & 6 & 1.002 & 0.51 & 2529 & 58.17 & 9245 & 58.11 & 4.88 & 3.65 \\
\hline $\mathrm{BF}_{2} \mathrm{P}$ & & & 6 & 1.013 & 0.51 & 2237 & 50.92 & 8010 & 50.92 & 4.78 & 3.72 \\
\hline $\mathbf{B F}_{3} \mathbf{P}$ & & & 6 & 1.046 & 0.52 & 2413 & 55.37 & 8128 & 53.45 & 4.64 & 3.74 \\
\hline $\mathrm{BW}_{1} \mathbf{P}$ & \multirow{2}{*}{$51 \%$} & \multirow{2}{*}{$30 \%$} & 6 & 0.982 & 0.350 & 765 & 54.90 & 11151 & 29.70 & 3.09 & 3.57 \\
\hline $\mathbf{B W}_{2} \mathbf{P}$ & & & 6 & 0.994 & 0.350 & 1128 & 55.61 & 8754 & 39.84 & 4.26 & 4.02 \\
\hline
\end{tabular}

$\mathrm{BF}_{\mathrm{n}} \mathrm{P}=$ Tension specimen number ' $\mathrm{n}$ ' from flange of the panel

$\mathrm{BW}_{\mathrm{n}} \mathrm{P}=$ Tension Specimen number ' $\mathrm{n}$ ' from web of the panel 


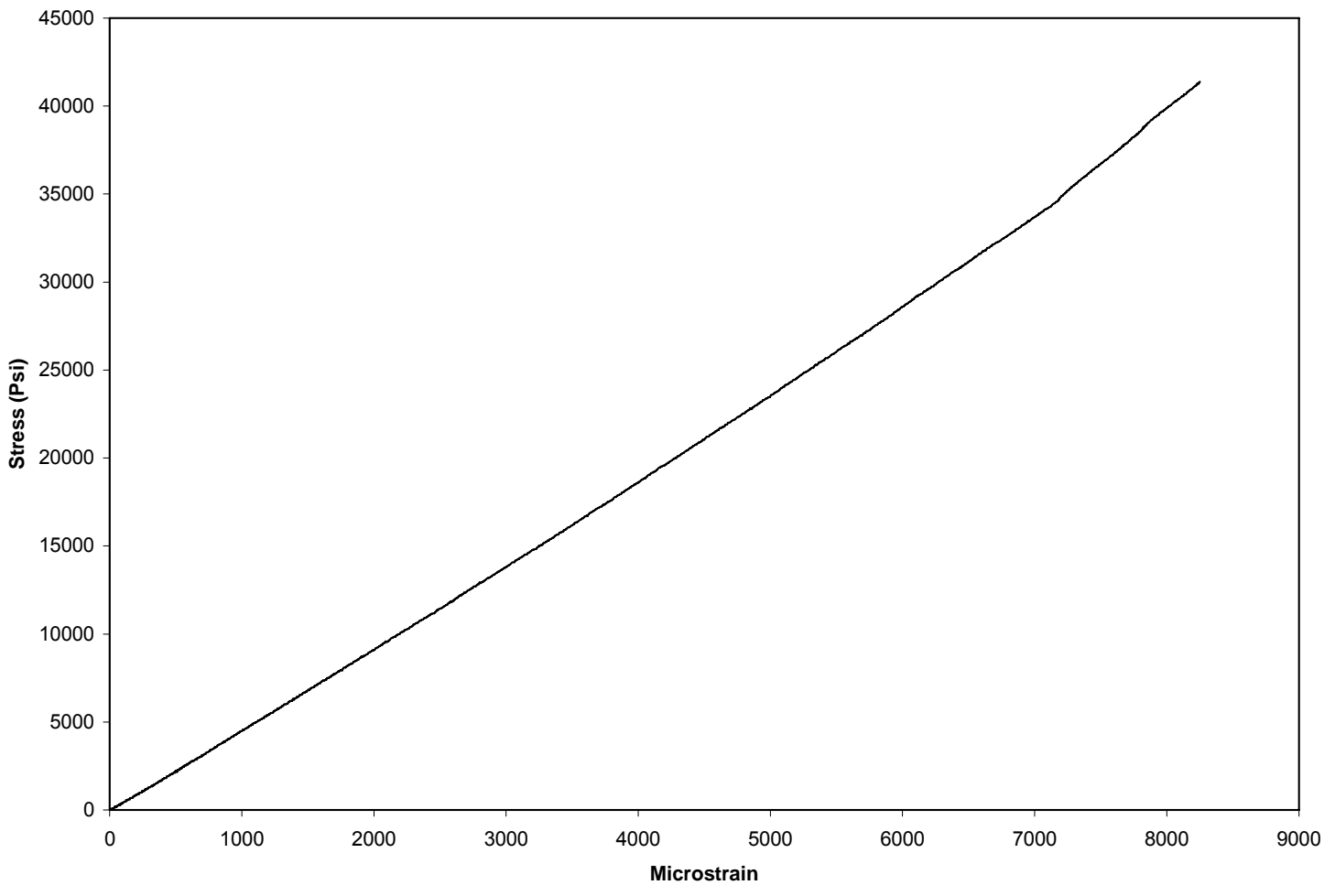

Figure 5.15 Stress Vs strain for specimen number $B F_{1} P$

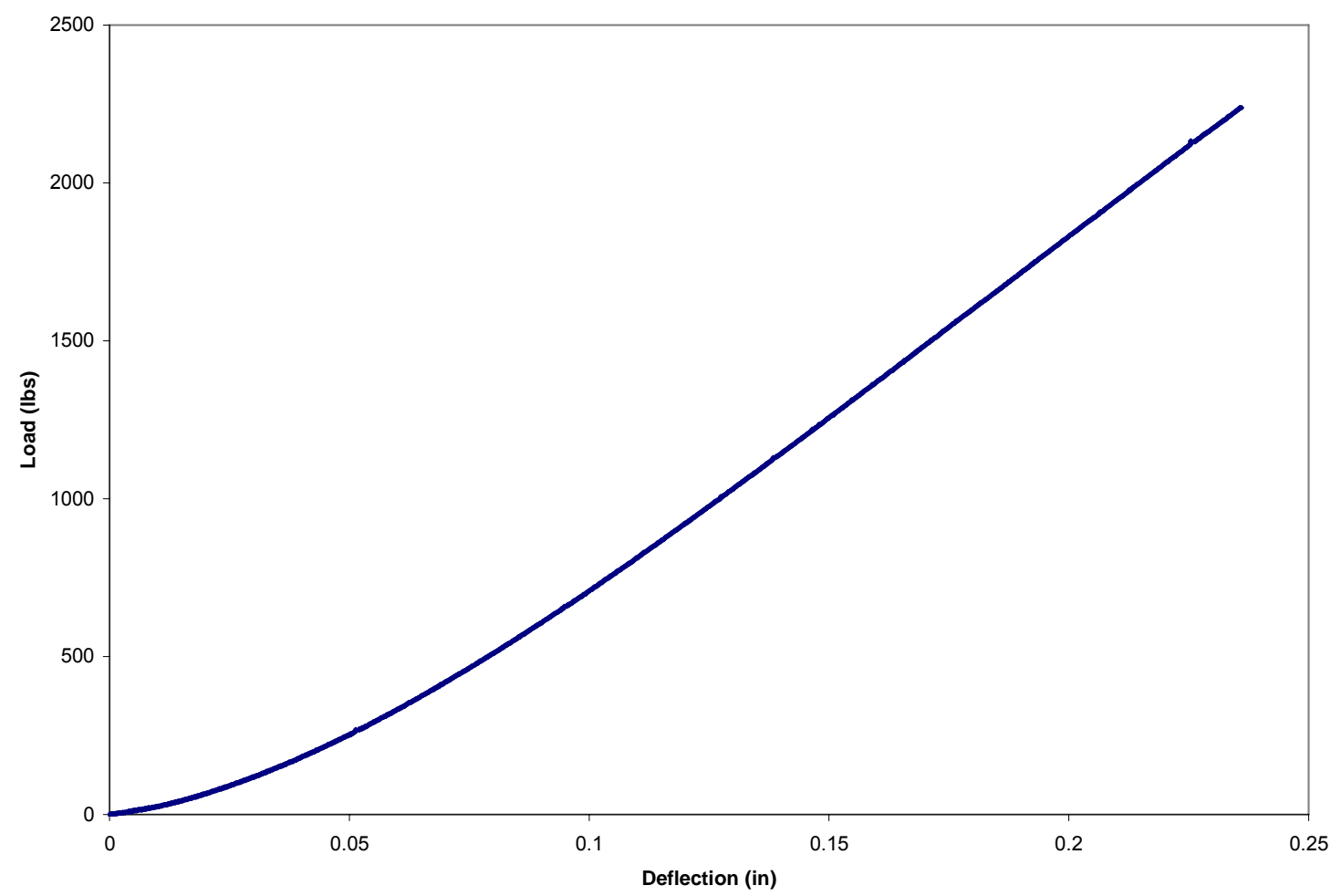

Figure 5.16 Load Vs deflection for specimen number $\mathrm{BF}_{\mathbf{1}} \mathrm{P}$ 


\section{Discussion of test results:}

The following observations were noted from bending tests on coupon specimens:

I. Similar to tension tests results, variation was noted in bending properties of coupon specimens cut from different locations.

II. The average ultimate bending stress was about $55 \mathrm{ksi}$ and $35 \mathrm{ksi}$ for flanges and webs respectively. The bending modulus was calculated from both stressstrain and load deflection curve. Modulus obtained from load-deflection curve takes into account global deflection and provides better representations of the overall stiffness as compared to stress-strain curve.

III. Figures 5.15 and 5.16 show the linear variation of stress-strain and loaddeflection of coupon specimen respectively.

\subsubsection{Short Beam Shear Test}

Out of plane shear strength is evaluated in this section. Maximum applied load, shear strength and failure mode are reported for all test specimens. Shear strengths of all coupons are provided in the Table 5.7 below.

Table 5.7 Ultimate shear strength of coupon specimens

\begin{tabular}{|c|c|c|c|c|c|c|c|c|}
\hline \multirow[b]{2}{*}{ Specimen } & \multicolumn{3}{|c|}{ Dimension } & \multirow[b]{2}{*}{$\mathbf{S} / \mathbf{t}$} & \multirow[b]{2}{*}{$\begin{array}{l}\text { Area } \\
\left(\text { in }^{2}\right)\end{array}$} & \multirow[b]{2}{*}{$\begin{array}{l}\text { Maximum } \\
\text { Load (lbs) }\end{array}$} & \multirow{2}{*}{$\begin{array}{l}\text { Average } \\
\text { Shear } \\
\text { Stress (ksi) }\end{array}$} & \multirow[b]{2}{*}{$\begin{array}{l}\text { Mode of } \\
\text { failure }\end{array}$} \\
\hline & $\begin{array}{l}S \\
\text { (in) }\end{array}$ & $\begin{array}{l}\text { B } \\
\text { (in) }\end{array}$ & $\begin{array}{l}\mathbf{t} \\
\text { (in) }\end{array}$ & & & & & \\
\hline SBF $_{1}$ & 1 & 0.52 & 0.5 & 2.00 & 0.26 & 4556 & 17.52 & \multirow{6}{*}{ Delamination } \\
\hline $\mathrm{SBF}_{2}$ & 1 & 0.49 & 0.5 & 2.00 & 0.245 & 3362 & 13.72 & \\
\hline $\mathrm{SBF}_{3}$ & 1 & 0.5 & 0.51 & 2.00 & 0.255 & 3544 & 13.89 & \\
\hline SBW $_{1}$ & 1 & 0.51 & 0.355 & 2.86 & 0.181 & 1500 & 8.23 & \\
\hline $\mathrm{SBW}_{2}$ & 1 & 0.5 & 0.35 & 2.86 & 0.175 & 1409 & 8.05 & \\
\hline $\mathrm{SBW}_{3}$ & 1 & 0.482 & 0.35 & 2.86 & 0.168 & 1134 & 6.75 & \\
\hline
\end{tabular}

SB: Short beam

$\mathrm{F}_{\mathrm{n}}$ : Specimens $\mathrm{n}=1,2 \ldots$ from flange

$\mathrm{W}_{\mathrm{n}}$ : Specimens $\mathrm{n}=1,2 \ldots$ from web

\section{Discussion of test results:}

The average shear stress of the coupon specimens obtained from flange was $14 \mathrm{ksi}$ and those from the web was $8 \mathrm{ksi}$. 


\subsubsection{Three Point Bending Test on Panels}

Three point bending test was done on two panel specimen with a span of 46 " and overhang of 3" at each end. The panels were loaded up to failure. Calculations were done to find the flexural rigidity of the panel as mentioned below. The cross sectional dimensions are shown in Figures 5.18 and 5.19. Stress-Strain curve for panel under three point bending test is shown in Figure 5.20. Load-Deflection curve for panel under three point bending is shown in Figure 5.21.

P: $58232 \mathrm{lb}$

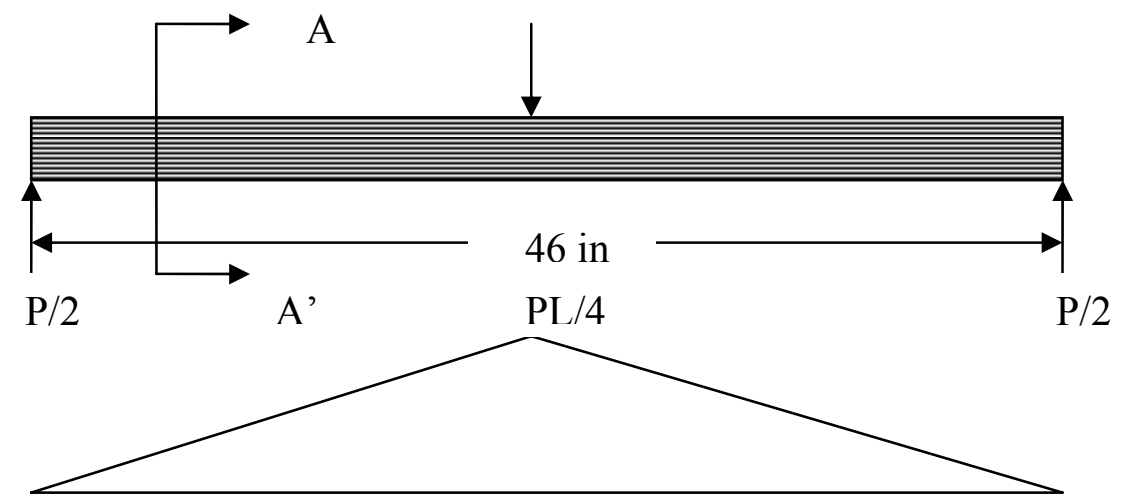

Figure 5.17 Bending moment diagram for three point bending test

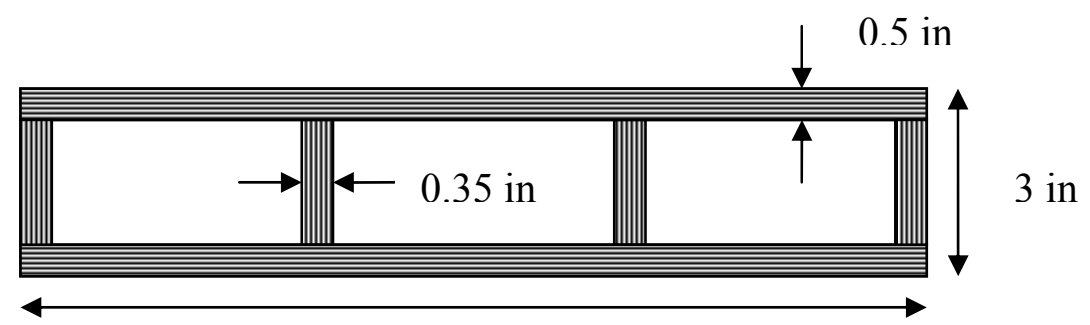

18.75 in

Figure 5.18 Section AA' for specimen 1

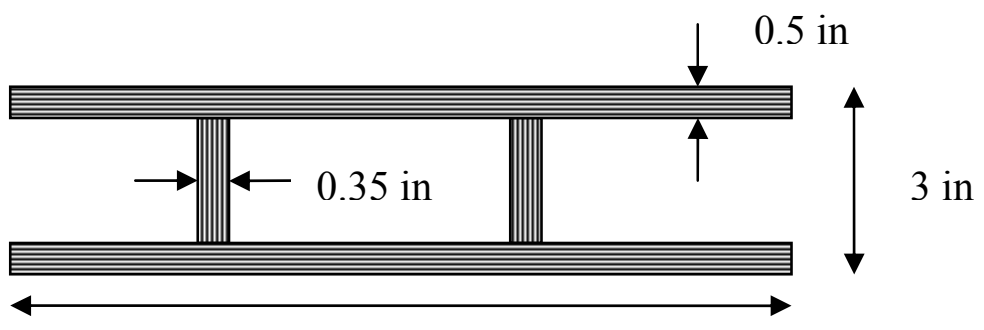

16.00 in

Figure 5.19 Section AA' for specimen 2 


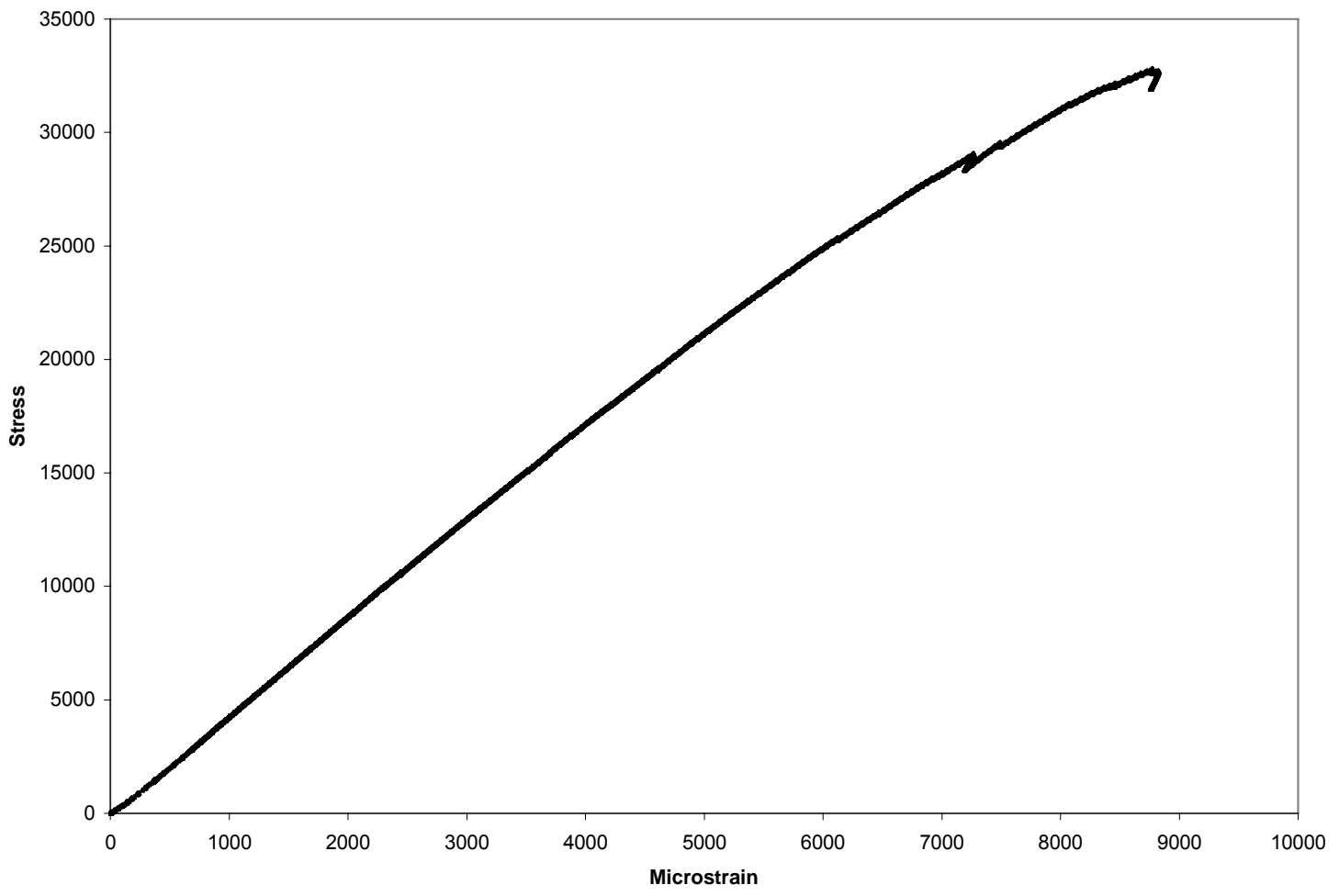

Figure 5.20 Stress Vs strain for panel (specimen 1) under three point bending

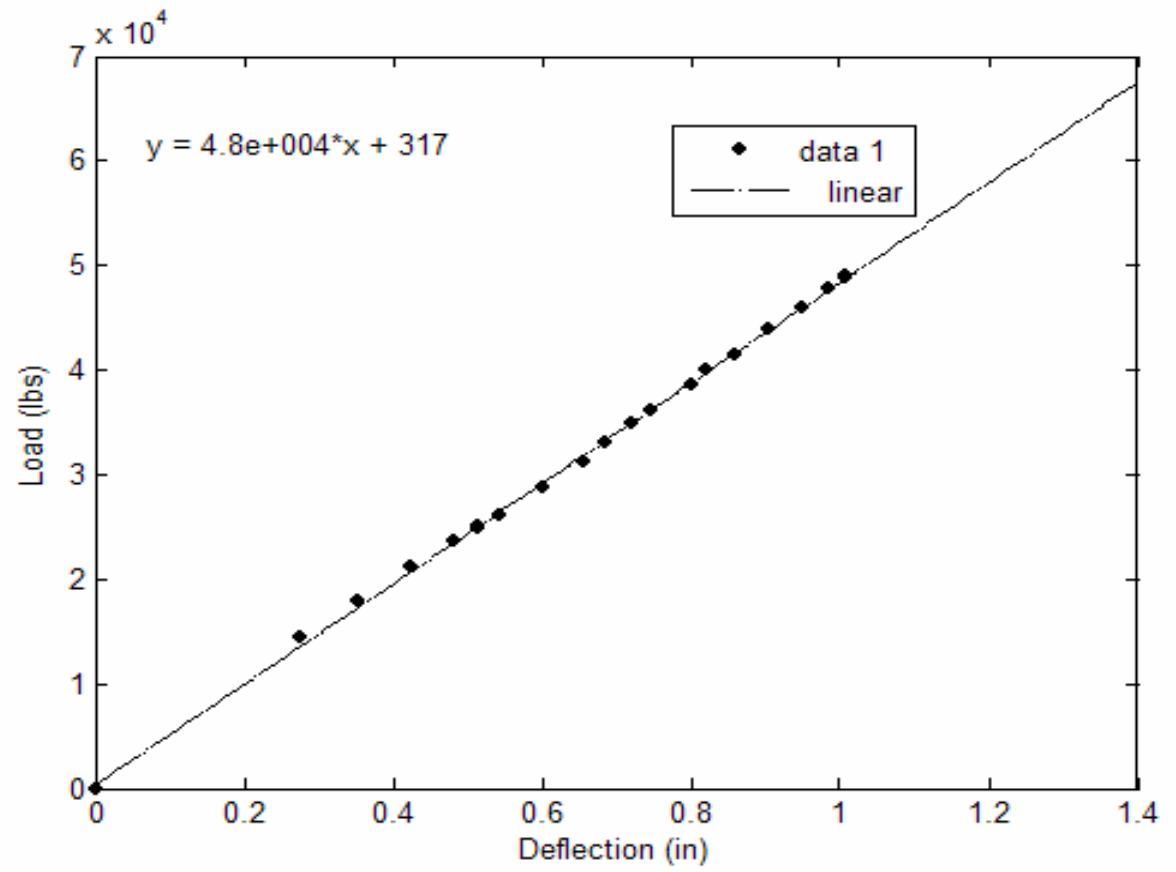

Figure 5.21 Load Vs deflection for panel (specimen 2) under three point bending 
Table 5.8 Experimental results of the three point bending test

\begin{tabular}{|c|c|c|c|c|c|c|c|c|c|}
\hline \multirow[b]{2}{*}{$\begin{array}{c}\text { Samp. } \\
\text { ID }\end{array}$} & \multirow[b]{2}{*}{ Span } & \multirow[b]{2}{*}{$\begin{array}{c}\text { Moment } \\
\text { of } \\
\text { inertia } \\
\left(\text { in }^{4}\right)\end{array}$} & \multirow[b]{2}{*}{$\begin{array}{c}\text { Neutral } \\
\text { axis } \\
\text { depth } \\
\text { (in) }\end{array}$} & \multirow[b]{2}{*}{$\begin{array}{c}\text { Ultimate } \\
\text { load at } \\
\text { failure } \\
\text { (lb) }\end{array}$} & \multirow[b]{2}{*}{$\begin{array}{c}\text { Ultimate } \\
\text { Stress at } \\
\text { failure } \\
\text { (ksi) }\end{array}$} & \multirow[b]{2}{*}{$\begin{array}{l}\text { Microstrai } \\
\text { n at failure }\end{array}$} & \multirow[b]{2}{*}{$\begin{array}{c}\text { Slope of } \\
\text { Load/Defle- } \\
\text { ction } \\
\text { Curve }(\mathrm{P} / \delta)\end{array}$} & \multicolumn{2}{|c|}{ E values (msi) } \\
\hline & & & & & & & & \begin{tabular}{|c} 
From \\
Stress \\
- \\
Strain \\
Data
\end{tabular} & $\begin{array}{l}\text { From Load- } \\
\text { Deflection } \\
\text { Data }\end{array}$ \\
\hline Panel 1 & 46 & 30.62 & 1.5 & 58232 & 32.80 & 8774 & 57399 & 3.74 & 3.80 \\
\hline Panel 2 & 46 & 25.82 & 1.5 & 49067 & 32.80 & ---- & 48426 & --- & 3.81 \\
\hline
\end{tabular}

\section{Discussion of test results:}

I. Average bending modulus of the panel load-deflection data was found to be $3.8 \mathrm{msi}$.

II. Average ultimate bending stress at failure was $32.80 \mathrm{ksi}$. Moments of inertias of the specimens are different as the widths of the specimens are not same. Cross sectional dimensions of test specimens are shown in Figure 5.18 and 5.19 .

III. Specimens 1 and 2 were loaded up to about $58 \mathrm{klbs}$ and $49 \mathrm{klbs}$ when first cracking noise was heard. It was observed that when the panels were unloaded, there were no visible permanent deformations of the cross section as well as there were no permanent deflections of the panel.

\subsubsection{SEM Pictures of Specimens Cut from Panel}

Specimens were cut from different locations of flanges and webs of panel specimen 1. Figure 5.22 shows the SEM pictures of specimens cut from the webs where the layers of unidirectional and $+45 /-45$ glass fibers are seen. Resin infusion at the web showed good fiber wet-out without air gaps (Figure 5.23). Similarly, fiber wet-out without air gaps was seen at the flange location (Figure 5.24). 

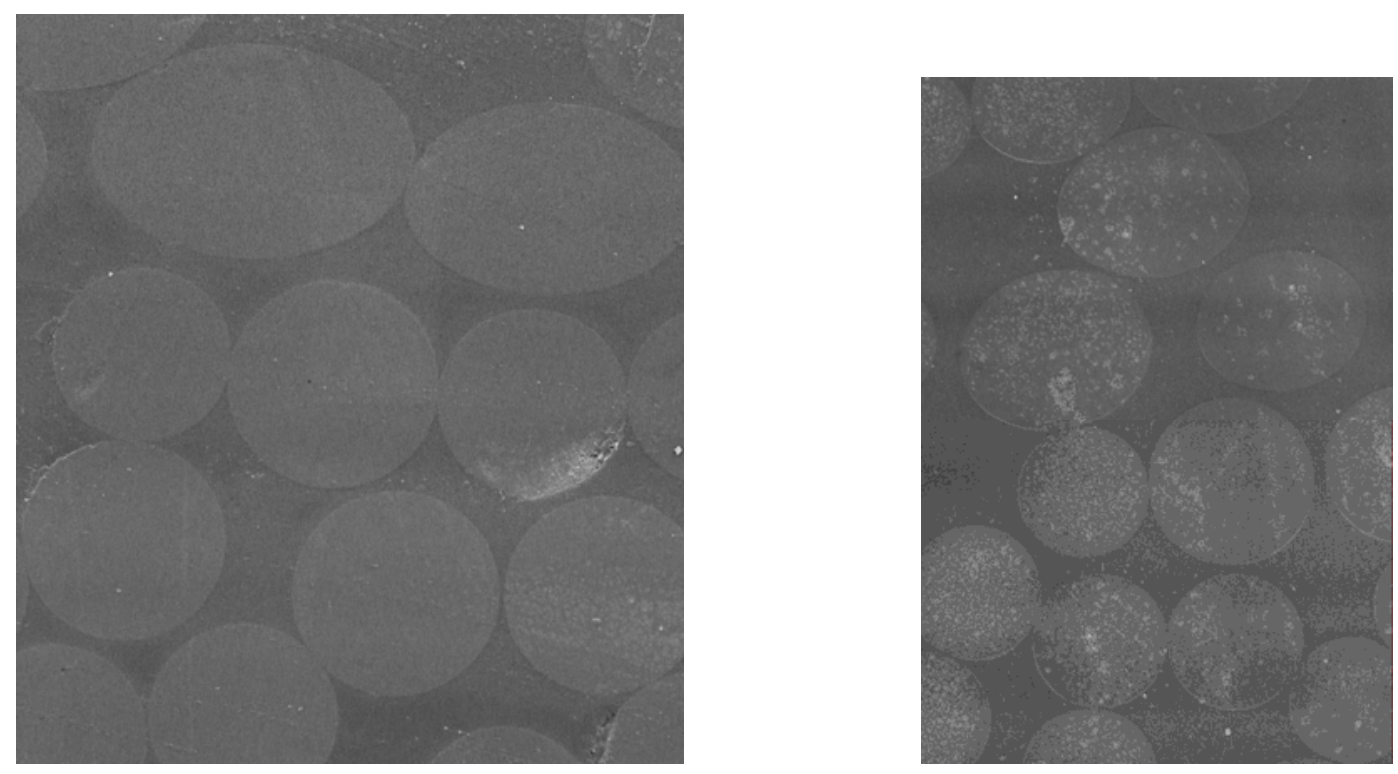

Figure 5.22 45/-45 and zero degree fibers at the web

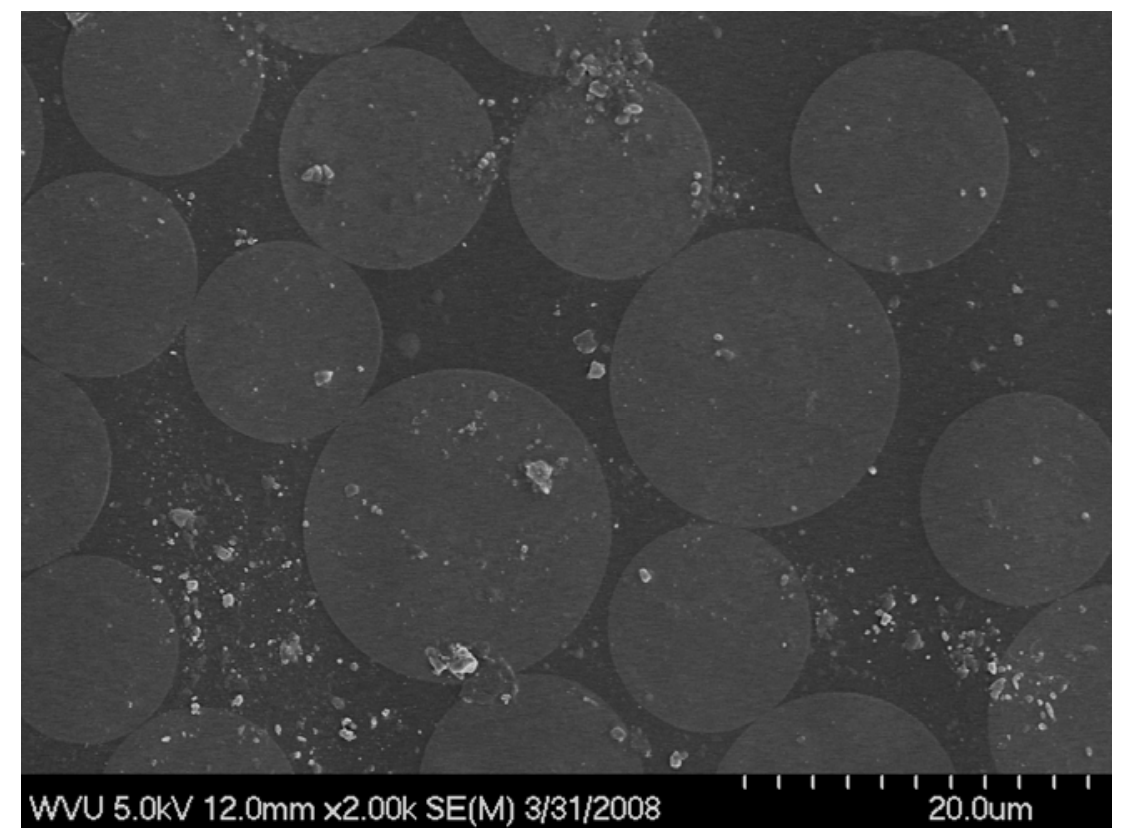

Figure 5.23 Uniform resin infusion in the web area 


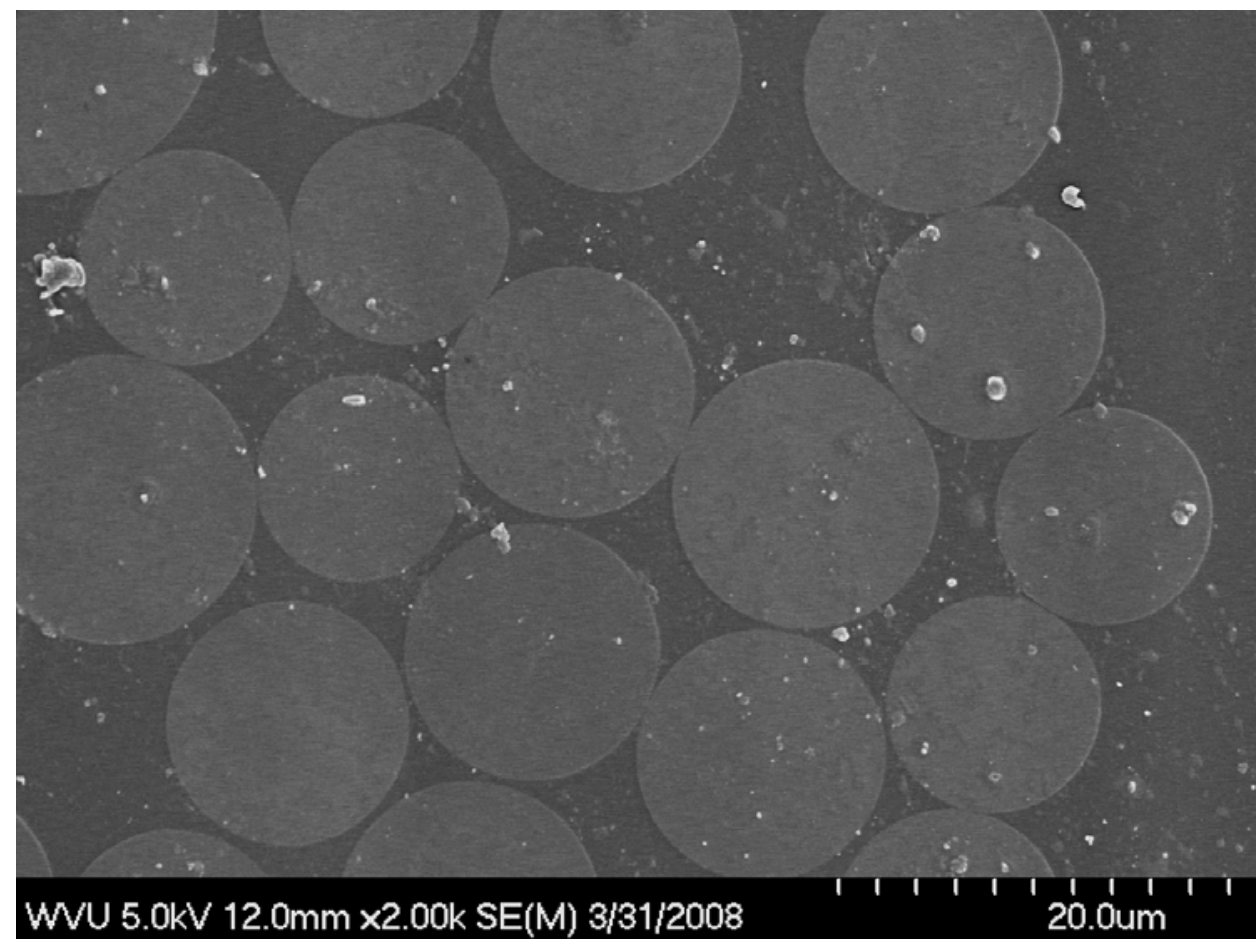

Figure 5.24 Uniformity of resin infusion in the flange area

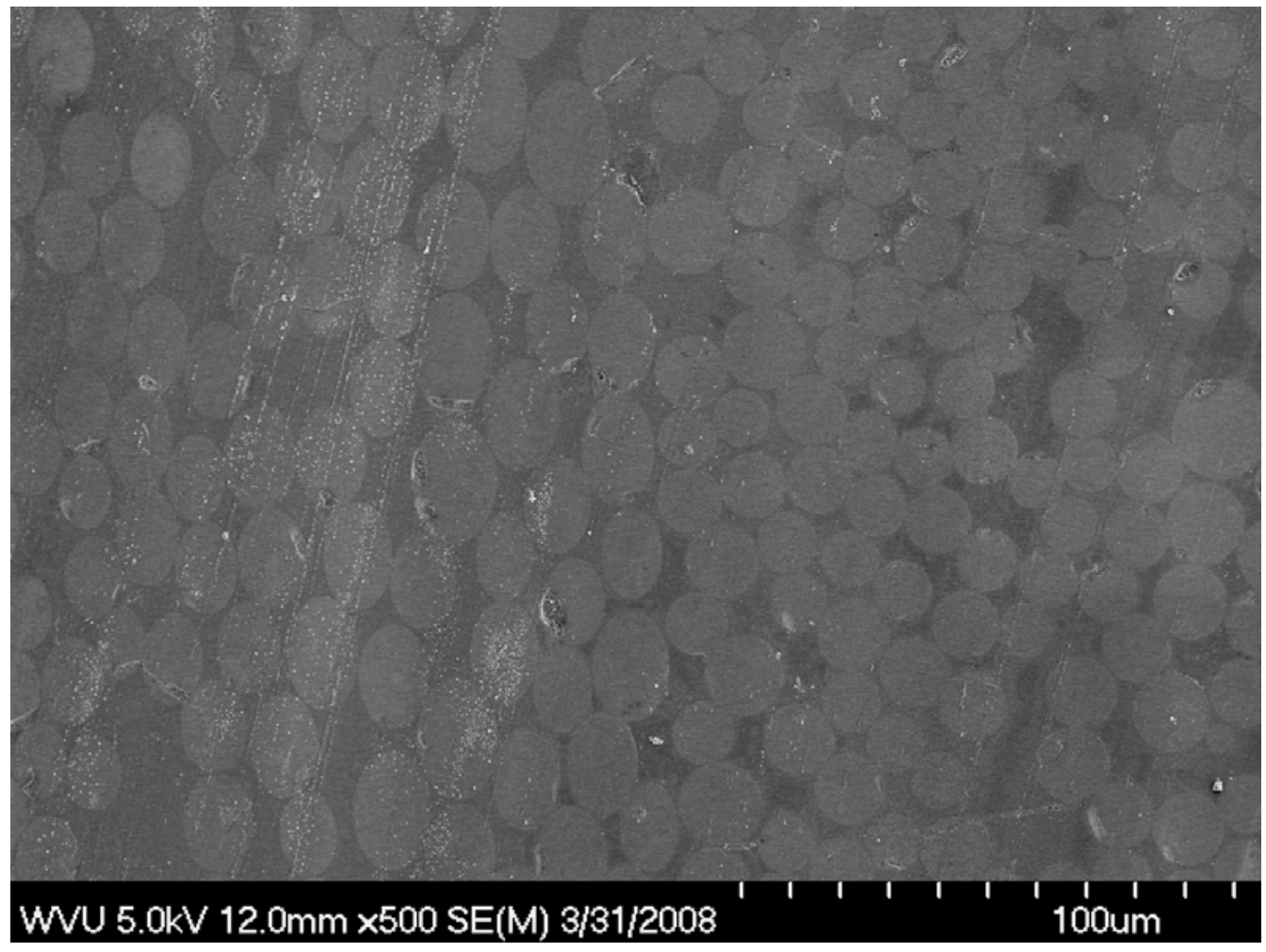

Figure 5.25 Good resin infusion and fiber wet-out at the web-flange junction 
Figure 5.25 shows good resin wet-out at the junction of web and flange. The oval and circular shapes represent the $+45 /-45$ and 0 degree fibers respectively. Figure 5.26 shows resin accumulation around a single fiber at the locations where sagging of the flange occurred.

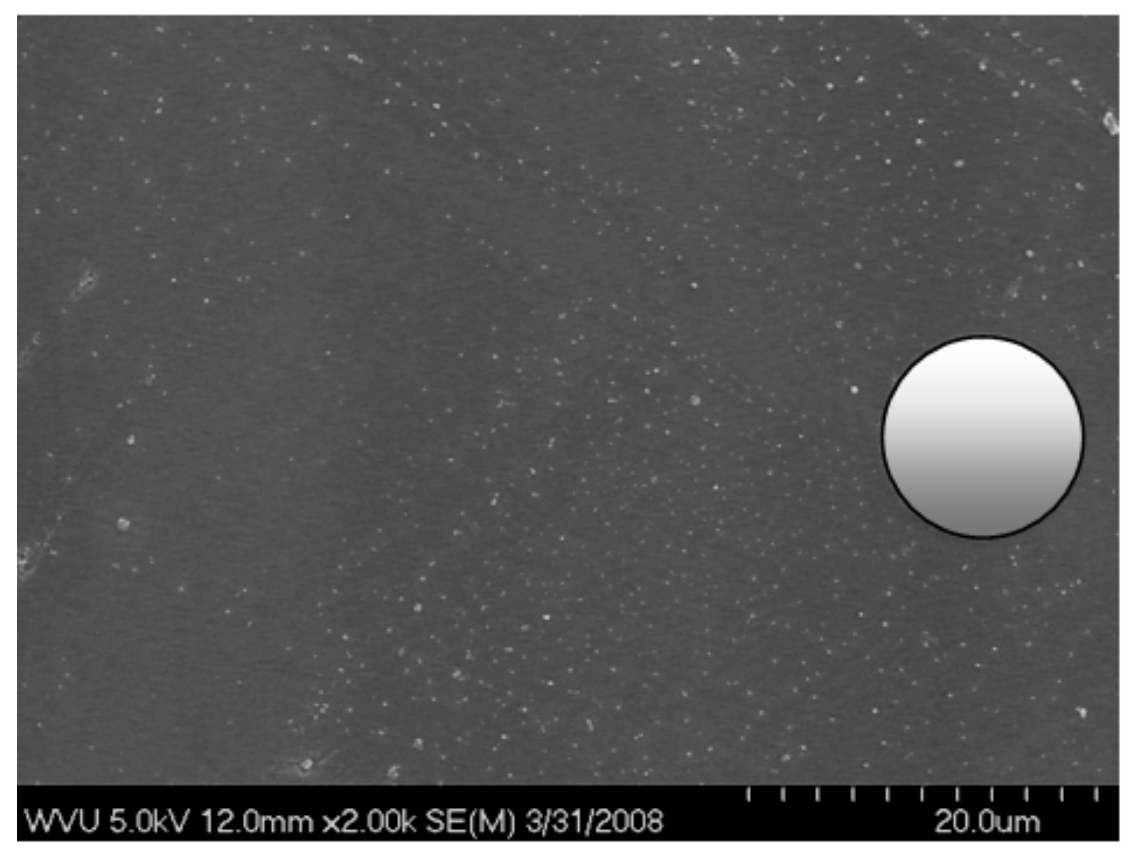

Figure 5.26 Excessive resin accumulation

\subsubsection{Phase II Panels}

In this section, different tests conducted on panels produced in phase II are discussed. The manufacturing procedure and fiber-fabric architecture of Phase II panels was already described in section 3.4.2. 


\subsubsection{Burn out Test Results}

Table 5.9 Burn out test

\begin{tabular}{|l|l|l|l|l|l|l|l|l|}
\hline $\begin{array}{l}\text { Sample } \\
\text { No }\end{array}$ & $\begin{array}{l}\text { Length } \\
\text { (in) }\end{array}$ & $\begin{array}{l}\text { Breadth } \\
\text { (in) }\end{array}$ & $\begin{array}{l}\text { Thickness } \\
\text { (in) }\end{array}$ & $\begin{array}{l}\mathbf{W}_{\mathbf{S}+\mathbf{C}} \\
(\mathbf{g m})\end{array}$ & $\begin{array}{l}\mathbf{W}_{\mathbf{C}} \\
(\mathbf{g m})\end{array}$ & $\begin{array}{l}\mathbf{W}_{\mathbf{f + C}} \\
\mathbf{( g m} \\
\mathbf{( b u r n})\end{array}$ & $\begin{array}{l}\mathbf{L B T} \\
\mathbf{( C C )}\end{array}$ & $\begin{array}{l}\mathbf{F V F} \\
\mathbf{( \% )}\end{array}$ \\
\hline $\mathbf{W}_{\mathbf{1}}$ & 0.995 & 1.045 & 0.410 & 32.23 & 18.18 & 27.62 & 6.980 & 54 \\
\hline $\mathbf{W}_{\mathbf{2}}$ & 1.002 & 1.040 & 0.420 & 32.75 & 18.15 & 27.64 & 7.050 & 53 \\
\hline $\mathbf{B F}_{\mathbf{1}}$ & 1.035 & 1.028 & 0.394 & 32.39 & 19.18 & 27.72 & 6.866 & 49 \\
\hline $\mathbf{B F}_{\mathbf{2}}$ & 1.030 & 1.030 & 0.400 & 33.28 & 19.34 & 27.67 & 6.948 & 48 \\
\hline $\mathbf{T F}_{\mathbf{1}}$ & 1.031 & 1.060 & 0.389 & 31.03 & 18.58 & 27.05 & 6.966 & 48 \\
\hline $\mathbf{T F 2}$ & 1.030 & 1.018 & 0.390 & 31.78 & 19.64 & 28.00 & 6.702 & 49 \\
\hline
\end{tabular}

Density of fiber $=2.522 \mathrm{gm} / \mathrm{cc}$.

$\mathrm{W}_{\mathrm{n}}=$ Web specimen number $\mathrm{n}$, where $\mathrm{n}=1,2, \ldots \ldots$

$\mathrm{F}_{\mathrm{n}}=$ Flange specimen number $\mathrm{n}$, where $\mathrm{n}=1,2, \ldots$

$\mathrm{W}_{\mathrm{C}}=$ Weight of empty crucible (in gms)

$\mathrm{W}_{\mathrm{c}+\mathrm{s}}=$ Weight of crucible + sample (in gms) before burn-out

$\mathrm{W}_{\mathrm{f}+\mathrm{c}}=$ Weight of fabric (left after resin burn) + crucible (in gms) after burn-out

\section{Discussion of burn out test results:}

Burn out test results revealed that average FVF fraction in the panel including webs and flanges was $49 \%$. In phase II manufacturing of the panel, resin infusion was excellent and uniform without resin accumulation and no sagging of the flanges.

\subsubsection{Tension Test Results}

Tension test results are discussed in this section. Table 5.10 presents the results of tension tests conducted on coupons cut from the flanges and the webs of the panel produced in phase II by Vacuum Assisted High Temperature Resin Infusion process.

\section{Discussion of test Results:}

The following observations were noted:

I. Ultimate average tensile stress of coupons (from flanges and webs) was 28.5 ksi. However, this uniformity of tensile properties was not observed in coupon 
test of specimens cut from the panel produced in phase I. Average normalized bending stress was observed to be $105 \mathrm{ksi}$.

II. In order to avoid cardboard related problems faced in phase I testing, in stead of grinding the cardboard off from the specimens, strain gages were mounted on the other face of the specimens cut from the flanges where there was no cardboard. Specimens cut from webs had cardboard on both sides and strain ranged from 9198-15841 Microstrain.

III. Figure 5.27 shows typical stress-strain curve of a sample cut from the bottom flange under tensile loads. Average tension modulus of specimens cut from the bottom flange was $2.58 \mathrm{msi}$. Cardboard attached to the outer surface provided initial stiffness to a specimen because of which stress-strain curve had two slopes. Initial slope of the curve was higher and the second slope was lower after cardboard breakage. To find the tensile modulus of the coupon specimens, we took average value over the whole data set. Figure 5.27 represents the stress-strain curve of the coupon sample cut from the top flange and the curve follows a similar two slope pattern.

IV. The tensile modulus of coupons cut from top flange was about $13 \%$ lower than those from bottom flange. This is attributed to: (a) better curing of the bottom surface which was in direct contact with the bottom heating plate of the infusion platform. The vacuum pressure on the top flange was distributed through a thick composite plate. There was no direct heating of the top flange of the panel (b) uniform vacuum pressure distribution took place on the bottom surface as it was directly sitting over a flat platform. On the other hand, top surface was sitting over the edge webs. Figure 5.27 also shows a typical stress-strain curve for a coupon specimens cut from the web under tensile loads. 
Table 5.10 Tension test results of coupon specimens

\begin{tabular}{|c|c|c|c|c|c|c|c|c|c|c|c|}
\hline $\begin{array}{l}\text { Sample } \\
\text { No }\end{array}$ & $\begin{array}{l}\text { Average } \\
\text { FVF } \\
(\%)\end{array}$ & $\begin{array}{l}\text { Average } \\
\text { FVF(\%) } \\
\text { in } \\
\text { loading } \\
\text { direction }\end{array}$ & $\begin{array}{l}\text { Gage } \\
\text { Length } \\
\text { (in) }\end{array}$ & $\begin{array}{l}\text { Tab } \\
\text { Length } \\
\text { (in) }\end{array}$ & $\begin{array}{l}\text { Thickness } \\
\text { (in) }\end{array}$ & $\begin{array}{l}\text { Width } \\
\text { (in) }\end{array}$ & $\begin{array}{l}\text { Ultimate } \\
\text { Stress } \\
\text { (ksi) }\end{array}$ & $\begin{array}{l}\text { Strain at gage } \\
\text { failure } \\
\text { (micro) }\end{array}$ & $\begin{array}{l}\text { Stress } \\
\text { at gage } \\
\text { failure } \\
\text { (ksi) }\end{array}$ & $\begin{array}{l}\text { Tension } \\
\text { Modulus } \\
\text { (msi) }\end{array}$ & $\begin{array}{l}\text { Normalized } \\
\text { Tensile } \\
\text { Stress (ksi) }\end{array}$ \\
\hline $\mathbf{B F}_{\mathbf{1}} \mathbf{P}_{\mathbf{t}}$ & \multirow{2}{*}{$49 \%$} & \multirow{2}{*}{$27.7 \%$} & 10 & 5 & 0.386 & 1.026 & 29.90 & 15264 & 27.00 & 2.60 & 108 \\
\hline $\mathbf{B F}_{2} \mathbf{P}_{t}$ & & & 10 & 5 & 0.397 & 1.024 & 29.11 & 15832 & 22.08 & 2.55 & 105 \\
\hline $\mathbf{T F}_{\mathbf{1}} \mathbf{P}_{\mathbf{t}}$ & \multirow{2}{*}{$49 \%$} & \multirow{2}{*}{$27.7 \%$} & 10 & 5 & 0.394 & 1.024 & 28.53 & 14923 & 27.82 & 2.30 & 103 \\
\hline $\mathbf{T F}_{2} \mathbf{P}_{t}$ & & & 10 & 5 & 0.387 & 1.025 & 28.29 & 15841 & 27.68 & 2.21 & 102 \\
\hline $\mathbf{W}_{\mathbf{1}} \mathbf{P}_{\mathbf{t}}$ & \multirow{2}{*}{$53 \%$} & \multirow{2}{*}{$27 \%$} & 10 & 5 & 0.430 & 0.990 & 28.00 & 9198 & 23.70 & 2.65 & 104 \\
\hline $\mathbf{W}_{\mathbf{2}} \mathbf{P}_{\mathbf{t}}$ & & & 10 & 5 & 0.411 & 0.976 & 28.10 & 10340 & 25.63 & 2.56 & 104 \\
\hline
\end{tabular}

$\mathrm{TF}_{\mathrm{n}} \mathrm{P}_{\mathrm{t}}$ : Top flange $\mathrm{n}=1,2 \ldots$ numbered sample from panel for tension test

$\mathrm{BF}_{n} \mathrm{P}_{\mathrm{t}}$ : Bottom flange $\mathrm{n}=1,2 \ldots$ numbered sample from panel for tension test

$\mathrm{WF}_{\mathrm{n}} \mathrm{P}_{\mathrm{t}}$ : Web $\mathrm{n}=1,2 \ldots$ numbered sample from panel for tension test 


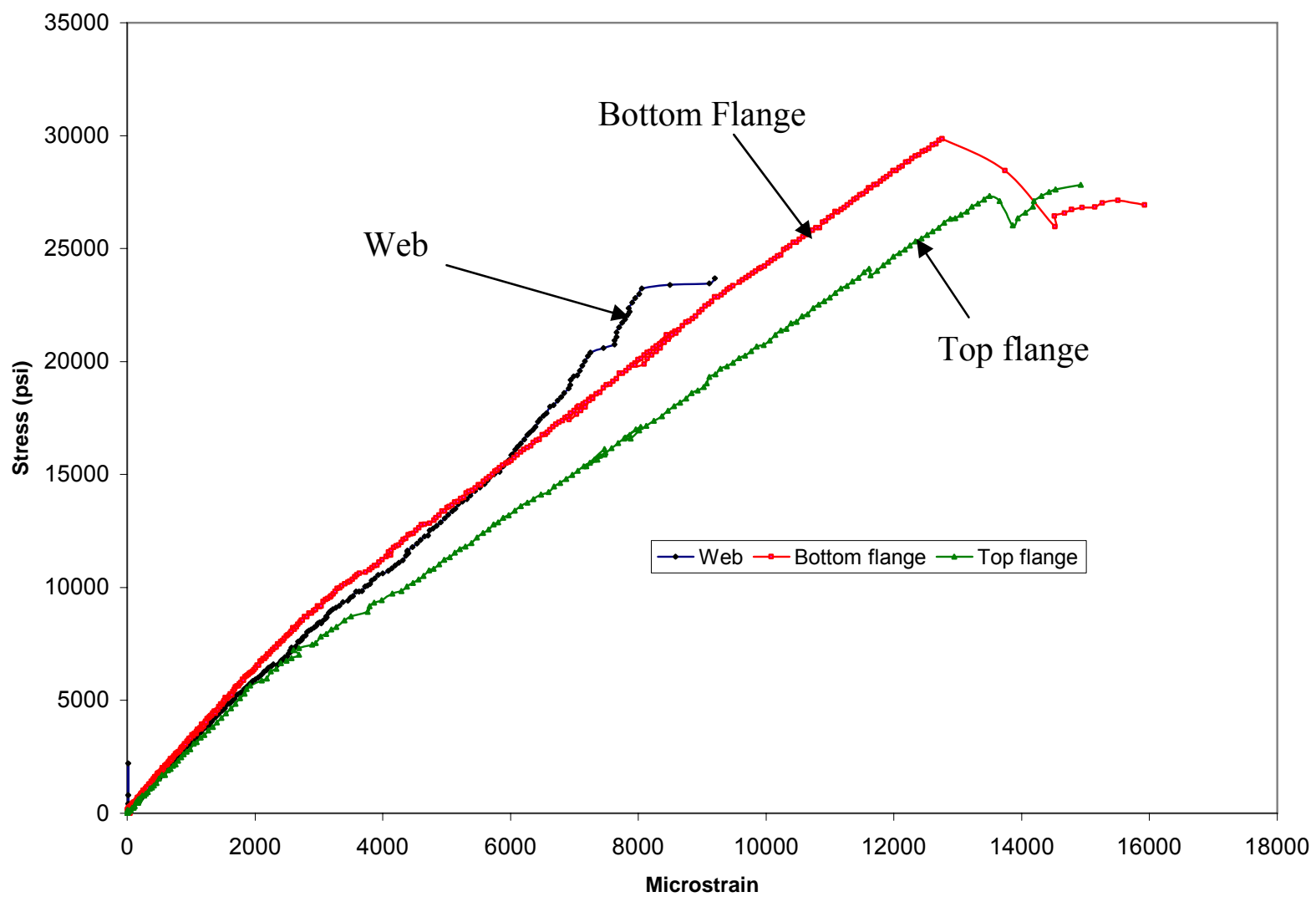

Figure 5.27 Stress Vs strain for tensile specimens from web, top and bottom flanges 


\subsubsection{Bending Test Results of Coupons}

This section discusses the bending test results conducted on coupon specimens cut from web, top and bottom flanges of the test panel.

Table 5.11 provides the bending test results.

Table 5.11 Four point bending test results of coupons

\begin{tabular}{|c|c|c|c|c|c|c|c|c|c|c|c|c|}
\hline \multirow{2}{*}{$\begin{array}{l}\text { Sample } \\
\text { No }\end{array}$} & \multirow{2}{*}{$\begin{array}{l}\text { Average } \\
\text { FVF } \\
(\%)\end{array}$} & \multirow{2}{*}{$\begin{array}{l}\text { Average } \\
\text { FVF in } \\
\text { loading } \\
\text { direction } \\
(\%)\end{array}$} & \multirow[b]{2}{*}{ Span(in) } & \multirow[b]{2}{*}{ Width(in) } & \multirow[b]{2}{*}{$\begin{array}{l}\text { Thick- } \\
\text { ness(in) }\end{array}$} & \multirow{2}{*}{$\begin{array}{l}\text { Ultimate } \\
\text { Load } \\
\text { (lbs) }\end{array}$} & \multirow{2}{*}{$\begin{array}{l}\text { Ultimate } \\
\text { Stress } \\
\text { (ksi) }\end{array}$} & \multirow{2}{*}{$\begin{array}{l}\text { Gage } \\
\text { Failure } \\
\text { Strain } \\
\text { (micro) }\end{array}$} & \multirow{2}{*}{$\begin{array}{l}\text { Gage } \\
\text { Failure } \\
\text { stress } \\
\text { (ksi) }\end{array}$} & \multicolumn{2}{|c|}{$\begin{array}{l}\text { Bending Modulus } \\
\text { (msi) }\end{array}$} & \multirow{2}{*}{$\begin{array}{l}\text { Normalized } \\
\text { Bending } \\
\text { Stress (ksi) }\end{array}$} \\
\hline & & & & & & & & & & $\begin{array}{l}\text { From } \\
\text { Stress- } \\
\text { Strain } \\
\end{array}$ & $\begin{array}{l}\text { From } \\
\text { Load- } \\
\text { Deflection }\end{array}$ & \\
\hline $\mathbf{B F}_{1} \mathbf{P}_{b}$ & \multirow{2}{*}{$49 \%$} & \multirow{2}{*}{$27.7 \%$} & 6 & 1.026 & 0.387 & 1218 & 47.60 & 9685 & 26.36 & 2.70 & 2.87 & 171 \\
\hline $\mathbf{B F}_{2} \mathbf{P}_{b}$ & & & 6 & 1.024 & 0.395 & 1458 & 54.70 & 15828 & 40.71 & 2.62 & 2.50 & 197 \\
\hline $\mathbf{T F}_{1} \mathbf{P}_{\mathrm{b}}$ & \multirow{2}{*}{$49 \%$} & \multirow{2}{*}{$27.7 \%$} & 6 & 1.024 & 0.394 & 1138 & 43.00 & 12619 & 27.35 & 2.20 & 2.04 & 155 \\
\hline $\mathbf{T F}_{\mathbf{2}} \mathbf{P}_{\mathrm{b}}$ & & & 6 & 1.025 & 0.387 & 1206 & 41.00 & 7732 & 18.48 & 2.34 & 2.00 & 154 \\
\hline $\mathbf{W}_{1} \mathbf{P}_{\mathbf{b}}$ & \multirow{2}{*}{$53 \%$} & \multirow{2}{*}{$27 \%$} & 6 & 0.990 & 0.430 & 1294 & 42.42 & 15870 & 36.03 & 2.30 & 2.20 & 157 \\
\hline $\mathbf{W}_{2} \mathbf{P}_{b}$ & & & 6 & 0.976 & 0.410 & 1312 & 47.10 & 14495 & 33.34 & 2.31 & 2.18 & 182 \\
\hline
\end{tabular}

$\mathrm{TF}_{\mathrm{n}} \mathrm{P}_{\mathrm{b}}$ : Top flange $\mathrm{n}=1,2 \ldots$ numbered sample from panel for bending test

$\mathrm{BF}_{\mathrm{n}} \mathrm{P}_{\mathrm{b}}$ : Bottom flange $\mathrm{n}=1,2 \ldots$ numbered sample from panel for bending test

$\mathrm{WF}_{n} \mathrm{P}_{b}$ : Web $\mathrm{n}=1,2 \ldots$ numbered sample from panel for bending test 


\section{Discussion of bending tests results:}

The following observations were noted:

I. Average ultimate bending stress was $45 \mathrm{ksi}$ for coupons.

II. Average bending modulus for coupons from bottom and top flange were 2.66 msi and 2.30 msi respectively. Coupons from the bottom flange provided higher bending stiffness than those from the top flange similar to tensile specimens testing discussed in section 5.3.2.2.

III. Strain to failure ranged from 7732-15828 Microstrain. Figures 5.28 shows stress-strain curves of coupons tested under four point bending.

IV. Stress-strain curves (Figure 5.28) were bi-linear as the cardboards attached one side of the specimen provided initial stiffness to the specimen.

V. Figure 5.29 shows the linear load-deflection curves of the specimens.

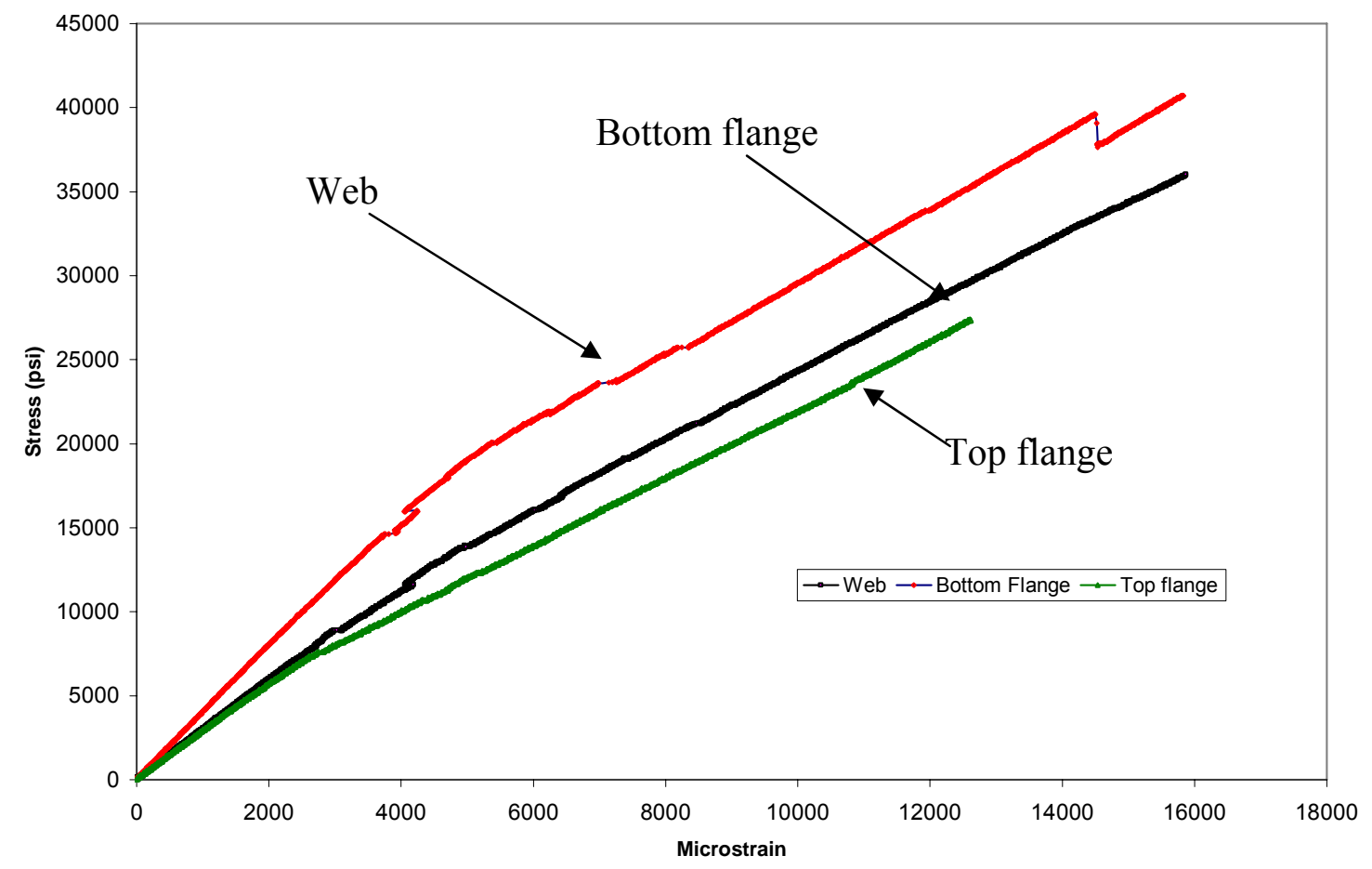

Figure 5.28 Stress Vs strain curve of specimens cut from web, top and bottom flange of the test panel 


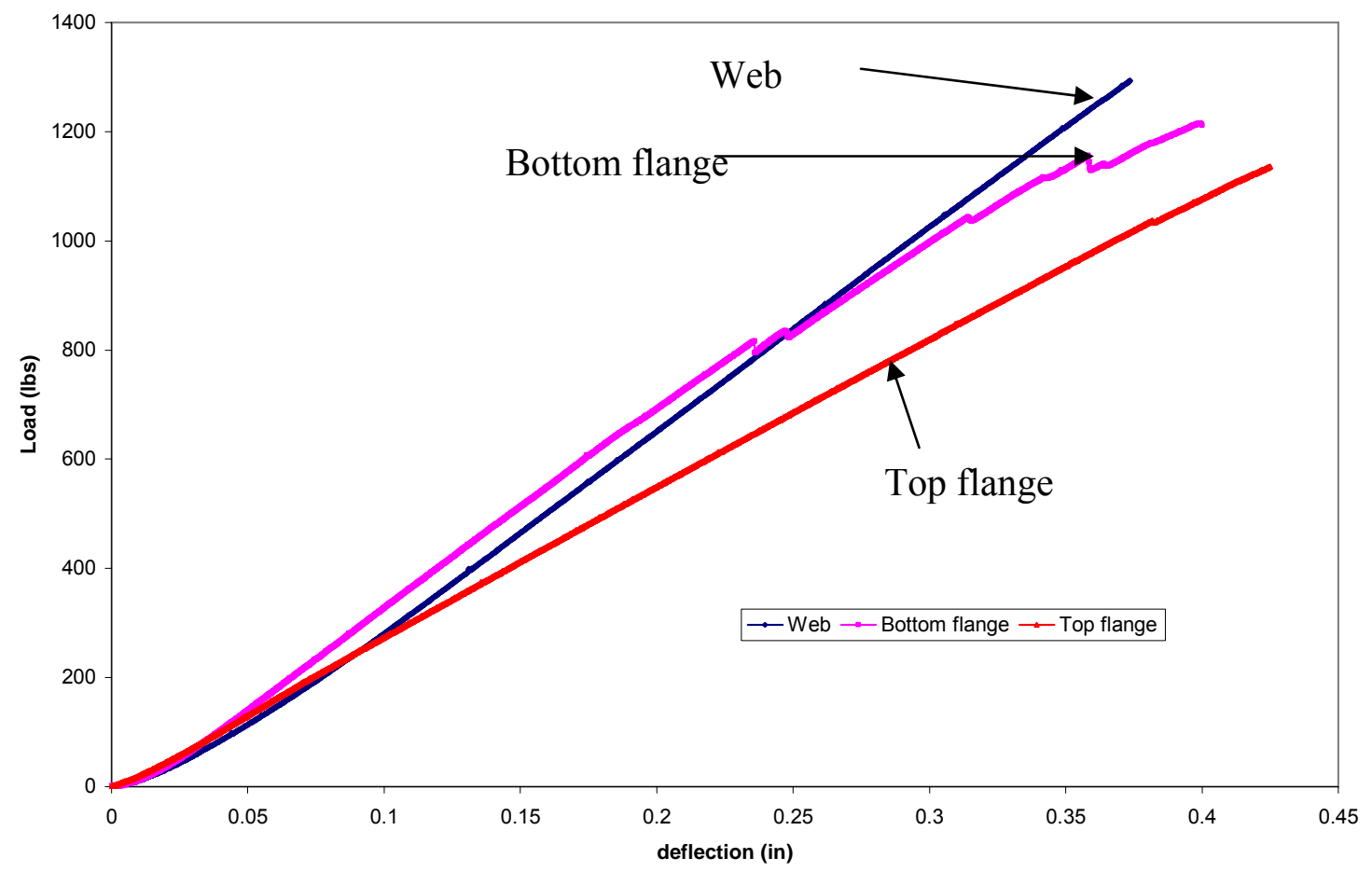

Figure 5.29 Stress Vs strain curve of specimens cut from web, top and bottom flange

\subsubsection{Short Beam Shear Test}

Table 5.12 presents the short beam shear test results.

Table 5.12 Short beam shear test results

\begin{tabular}{|c|c|c|c|c|c|c|c|c|}
\hline \multirow[b]{2}{*}{ Specimen } & \multicolumn{3}{|c|}{ Dimension } & \multirow[b]{2}{*}{$\mathbf{S} / \mathbf{t}$} & \multirow[b]{2}{*}{$\begin{array}{l}\text { Area } \\
\left(\text { in }^{2}\right)\end{array}$} & \multirow{2}{*}{$\begin{array}{l}\text { Maximum } \\
\text { Load (lbs) }\end{array}$} & \multirow{2}{*}{$\begin{array}{l}\text { Average } \\
\text { Shear Stress } \\
\text { (ksi) } \\
\end{array}$} & \multirow{2}{*}{$\begin{array}{l}\text { Mode of } \\
\text { failure }\end{array}$} \\
\hline & $\begin{array}{l}S \\
\text { (in) }\end{array}$ & $\begin{array}{l}\mathbf{B} \\
\text { (in) }\end{array}$ & $\begin{array}{l}\mathbf{t} \\
\text { (in) }\end{array}$ & & & & & \\
\hline $\mathrm{TF}_{\mathbf{1}} \mathbf{P}_{\mathrm{sb}}$ & 1 & 0.5 & 0.380 & 2.6 & 0.190 & 1328 & 5.23 & \multirow{8}{*}{ Delamination } \\
\hline $\mathrm{TF}_{\mathbf{2}} \mathbf{P}_{\mathrm{sb}}$ & 1 & 0.5 & 0.381 & 2.6 & 0.190 & 1219 & 4.80 & \\
\hline $\mathbf{T F}_{\mathbf{3}} \mathbf{P}_{\mathrm{sb}}$ & 1 & 0.5 & 0.38 & 2.6 & 0.190 & 1396 & 5.51 & \\
\hline $\mathrm{BF}_{1} \mathbf{P}_{\mathrm{sb}}$ & 1 & 0.5 & 0.39 & 2.6 & 0.195 & 1414 & 5.44 & \\
\hline $\mathrm{BF}_{2} \mathbf{P}_{\mathrm{sb}}$ & 1 & 0.5 & 0.38 & 2.6 & 0.190 & 1432 & 5.66 & \\
\hline $\mathrm{BF}_{\mathbf{3}} \mathbf{P}_{\mathrm{sb}}$ & 1 & 0.5 & 0.38 & 2.6 & 0.190 & 1389 & 5.48 & \\
\hline $\mathrm{WF}_{\mathbf{1}} \mathbf{P}_{\mathbf{s b}}$ & 1 & 0.5 & 0.401 & 2.5 & 0.200 & 1723 & 6.50 & \\
\hline $\mathbf{W F}_{2} \mathbf{P}_{\mathbf{s b}}$ & 1 & 0.5 & 0.400 & 2.5 & 0.200 & 1742 & 6.53 & \\
\hline
\end{tabular}

$\mathrm{TF}_{\mathrm{n}} \mathrm{P}_{\mathrm{sb}}$ : Top flange $\mathrm{n}=1,2 \ldots$ numbered sample from panel for short beam test

$\mathrm{BF}_{\mathrm{n}} \mathrm{P}_{\mathrm{sb}}$ : Bottom flange $\mathrm{n}=1,2 \ldots$ numbered sample from panel for short beam test

$\mathrm{WF}_{n} \mathrm{P}_{\mathrm{sb}}:$ Web $\mathrm{n}=1,2 \ldots$ numbered sample from panel for short beam test 


\section{Discussion of test results:}

Average ultimate shear stress was found to be $5.65 \mathrm{ksi}$. Web fiber/fabric clamping resulted in higher web shear strength than that of the flange in phase II.

\subsubsection{Three Point (Patch Load) Bending Test of Panel}

The panel was tested under patch loading at the center. The truck wheel loading was simulated with a patch load of dimensions 10 inch $\times 20$ inch with 20 inch as the width of the wheel. To determine the effect of loading on top and bottom panel surfaces, we tested the panel under four different combinations. Figure 5.30 represents four types of panel surface and patch loading orientations were considered for testing.

Type I: Glossy Surface (Bottom Surface while infusing) at top and patch loading 10 inch x 20 inch with 20 inch along the transverse direction

Type II: Glossy Surface (Bottom Surface while infusing) at top and patch loading 10 inch x 20 inch with 20 inch along the longitudinal direction

Type III: Top Surface (Top Surface while infusing) at top and patch loading 10 inch x 20 inch with 20 inch along the transverse direction

Type IV: Top Surface (Top Surface while infusing) at top and patch loading 10 inch x 20 inch with 20 in along the longitudinal direction

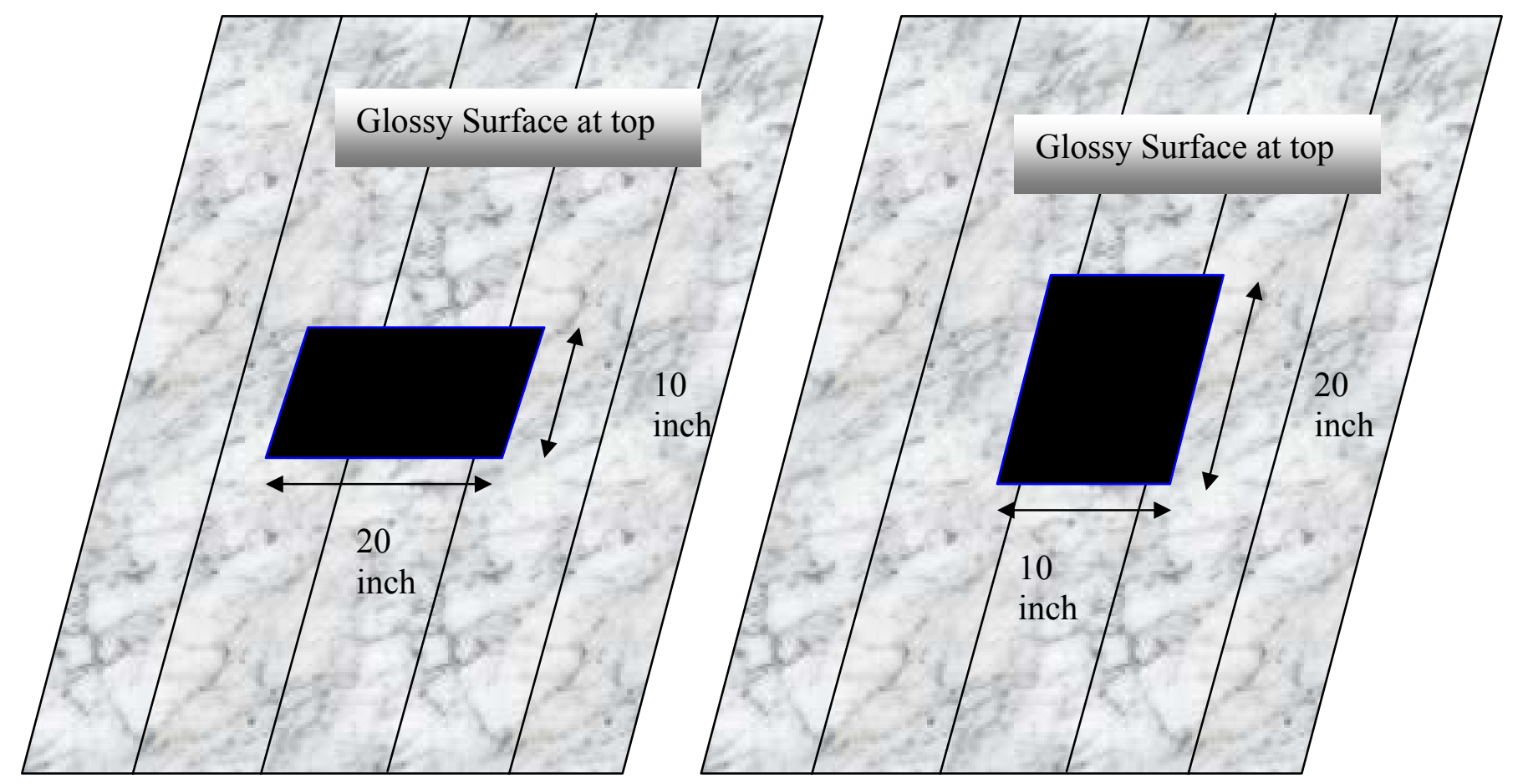

(a) Type I configuration

(b) Type II configuration 


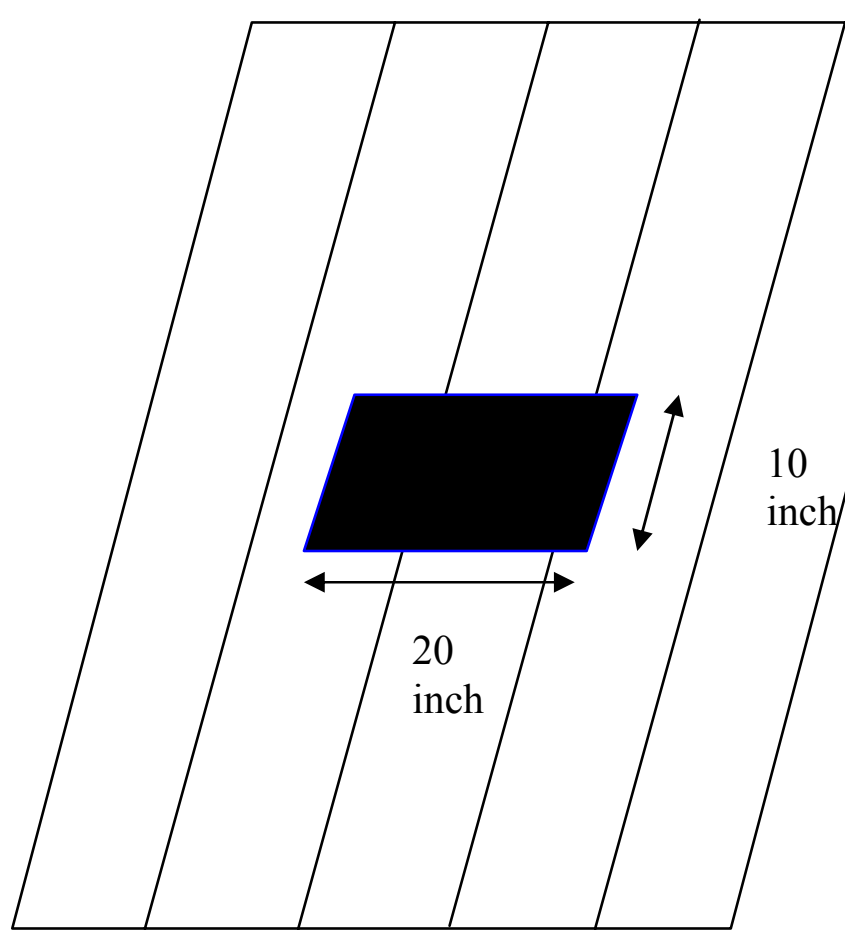

(c) Type III configuration

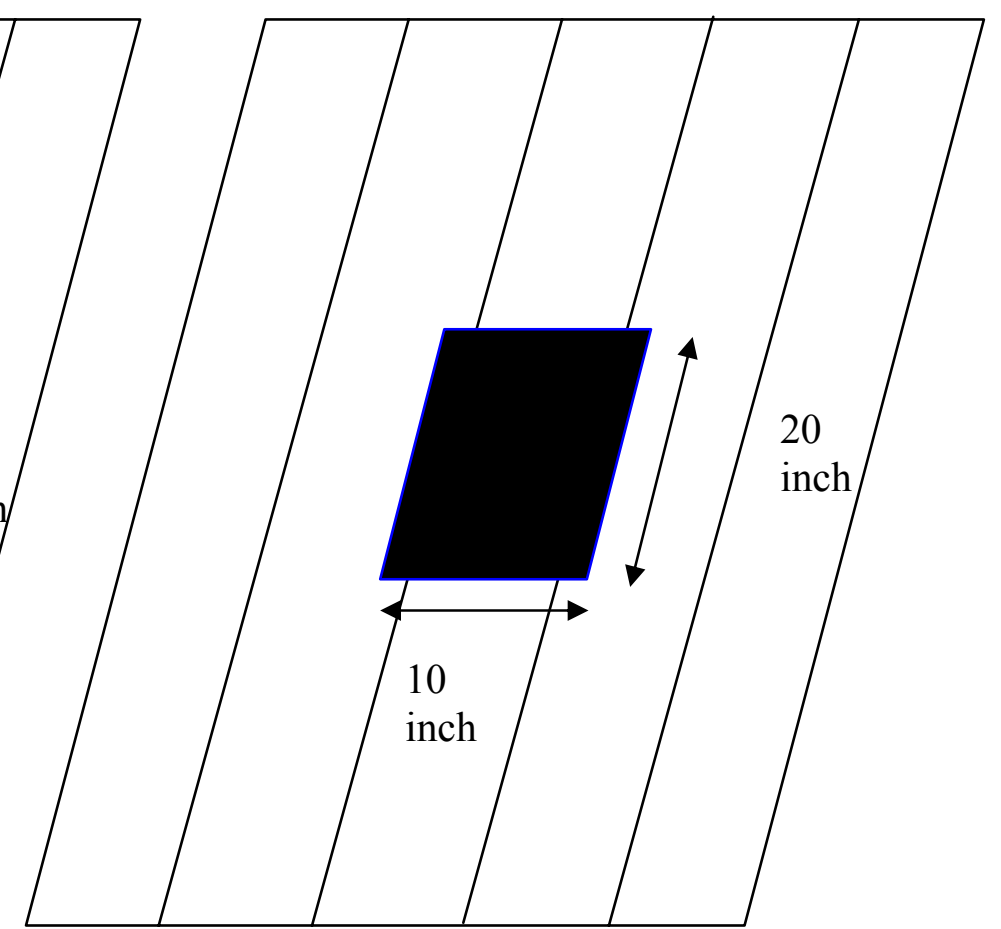

(d) Type IV configuration

Figure 5.30 Different panel orientations, surface and patch load configurations

The panel was subjected up to 2 million cycles of fatigue load and type III loading configuration (Figure 5.30) was followed. After predetermined number of cycles, the FRP panel was loaded statically up to 23 kips over the gravel base. Strains were measured on bottom and top flanges of FRP panel. The panel was also simply supported with roller support at each end and tested under a 20 inch x 10 inch patch load. This patch load test was conducted at the beginning of fatigue load, after 1 million and 2 million fatigue cycles. Table 5.17 presents the panel modulus values calculated from stress-strain and load deflection curves (Figures 5.31 to 5.38$)$. 
Table 5.13 Three point (patch load) bending test results of panel

\begin{tabular}{|c|c|c|c|c|c|c|c|}
\hline \multirow[b]{2}{*}{$\begin{array}{l}\text { No of } \\
\text { Cycles }\end{array}$} & \multirow[b]{2}{*}{$\begin{array}{l}\text { Loading } \\
\text { Type }\end{array}$} & \multirow[b]{2}{*}{$\begin{array}{l}\text { Span } \\
\text { (in) }\end{array}$} & \multirow[b]{2}{*}{$\begin{array}{l}\text { Moment of } \\
\text { inertia }\left(\text { in }^{4}\right)\end{array}$} & \multirow[b]{2}{*}{$\begin{array}{c}\text { Slope of } \\
\text { Load/Deflection } \\
\text { Curve }(\mathbf{P} / \delta)\end{array}$} & \multirow{2}{*}{$\begin{array}{c}\text { E Values (msi) } \\
\text { (Compression Flange) } \\
\begin{array}{c}\text { From Stress-Strain } \\
\text { Data }\end{array}\end{array}$} & \multicolumn{2}{|c|}{$\begin{array}{c}\text { E values (msi) (Tension } \\
\text { Flange) }\end{array}$} \\
\hline & & & & & & $\begin{array}{c}\text { From } \\
\text { Stress- } \\
\text { Strain } \\
\text { Data } \\
\end{array}$ & $\begin{array}{c}\text { From Load- } \\
\text { Deflection Data }\end{array}$ \\
\hline \multirow{4}{*}{$\begin{array}{l}\text { Zero Cyclic } \\
\text { Loading }\end{array}$} & $\mathrm{I}$ & 67 & 30.5 & 15043 & 3.48 & 2.56 & 3.09 \\
\hline & II & 67 & 30.5 & 16363 & 2.91 & 2.35 & 3.36 \\
\hline & III & 67 & 30.5 & 16182 & 3.27 & 3.29 & 3.32 \\
\hline & IV & 67 & 30.5 & 14824 & 3.02 & 3.06 & 3.05 \\
\hline \multirow{4}{*}{$\begin{array}{l}1 \text { Million } \\
\text { Cyclic } \\
\text { Loading }\end{array}$} & I & 67 & 30.5 & 11624 & 2.15 & 2.12 & 2.39 \\
\hline & II & 67 & 30.5 & 12717 & 2.78 & 2.34 & 2.61 \\
\hline & III & 67 & 30.5 & 14938 & 3.29 & 3.29 & 3.00 \\
\hline & IV & 67 & 30.5 & 13603 & 3.03 & 3.04 & 2.80 \\
\hline \multirow{4}{*}{$\begin{array}{l}2 \text { Million } \\
\text { Cyclic } \\
\text { Loading }\end{array}$} & I & 67 & 30.5 & 11381 & --- & 2.62 & 2.34 \\
\hline & II & 67 & 30.5 & 11473 & 2.97 & 2.65 & 2.36 \\
\hline & III & 67 & 30.5 & 12769 & 3.24 & 3.33 & 2.62 \\
\hline & IV & 67 & 30.5 & 12145 & 2.96 & 3.15 & 2.50 \\
\hline
\end{tabular}




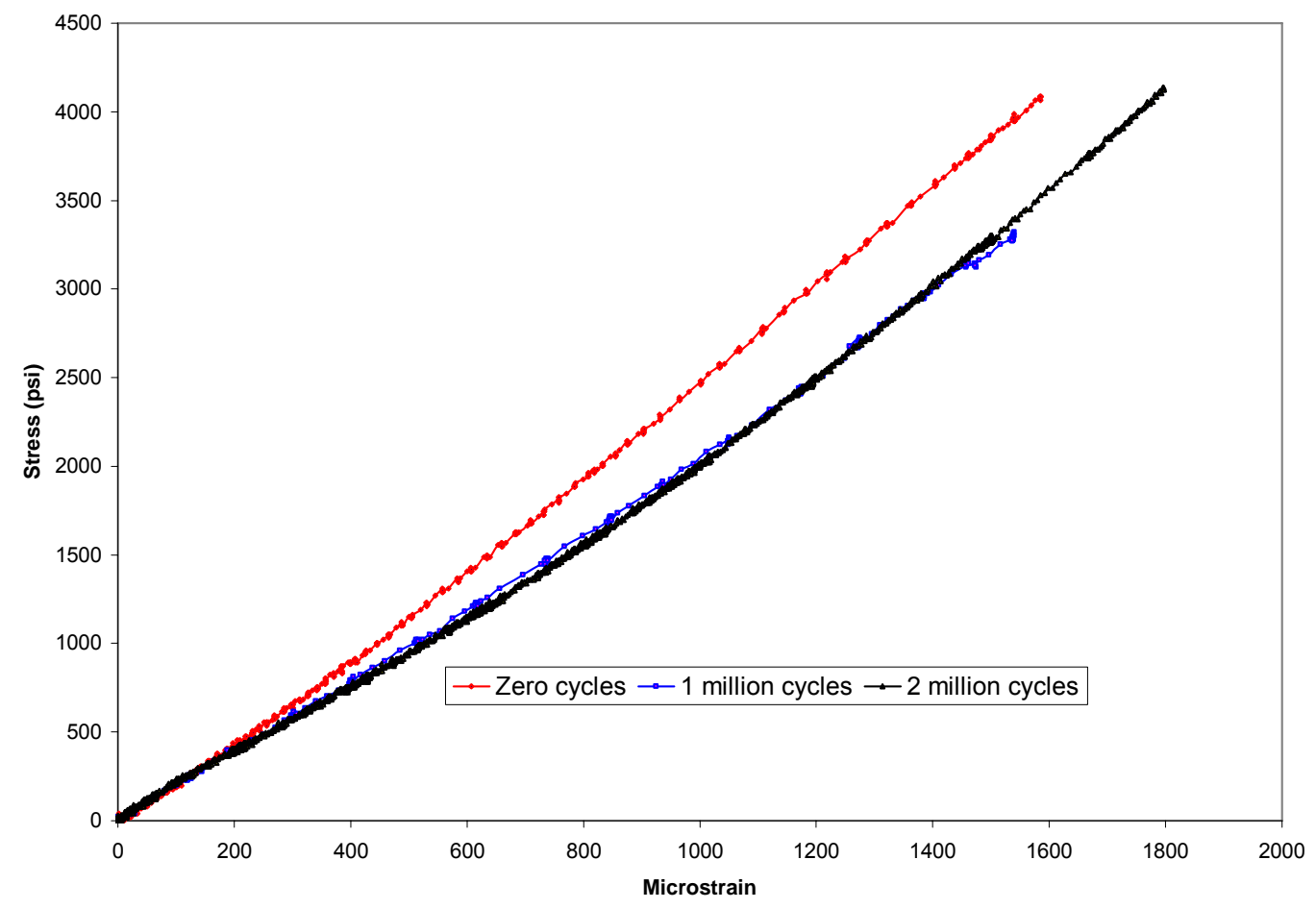

Figure 5.31 Tensile stress at bottom flange Vs strain for type I loading

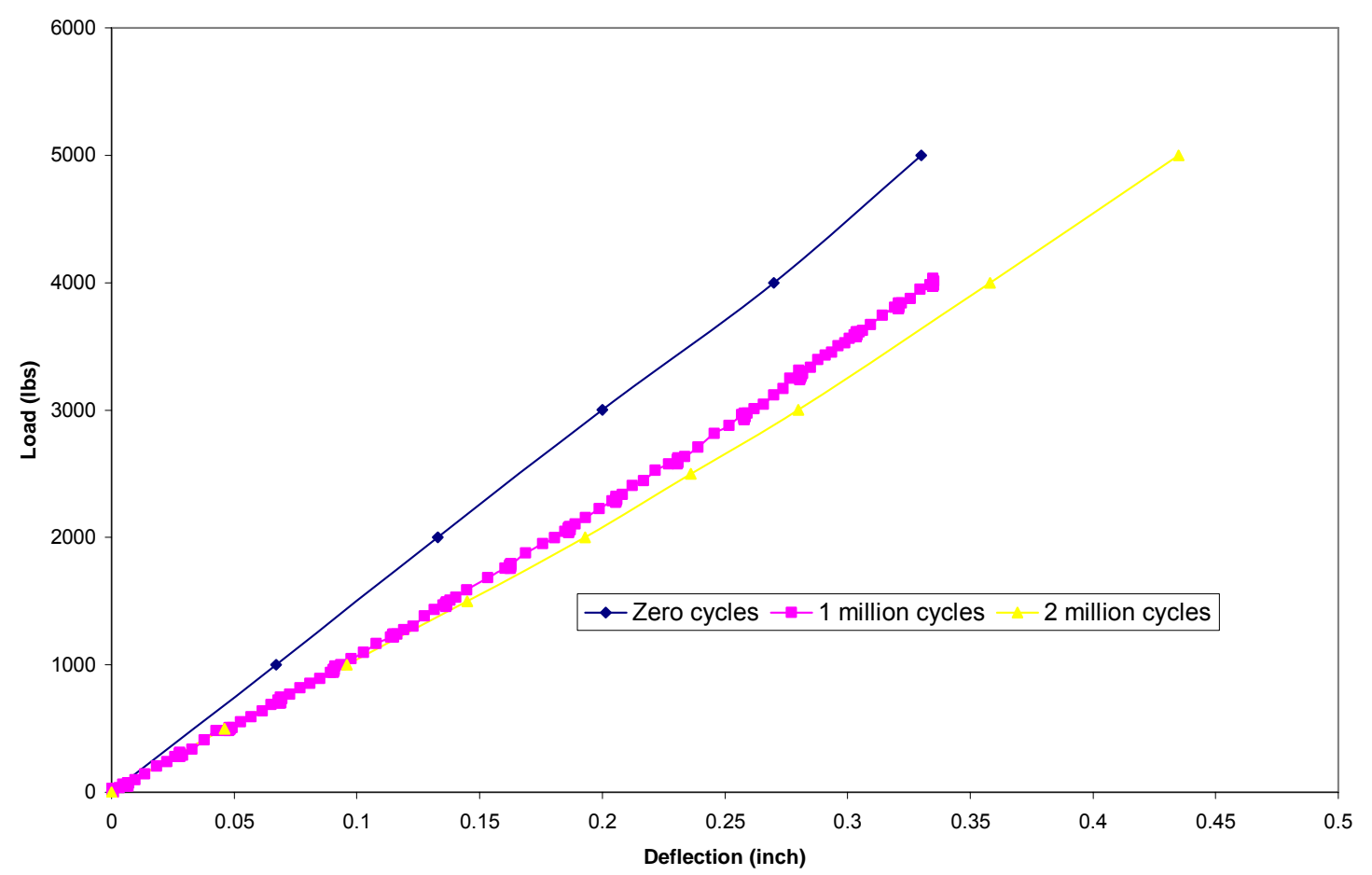

Figure 5.32 Load Vs deflection for type I loading 


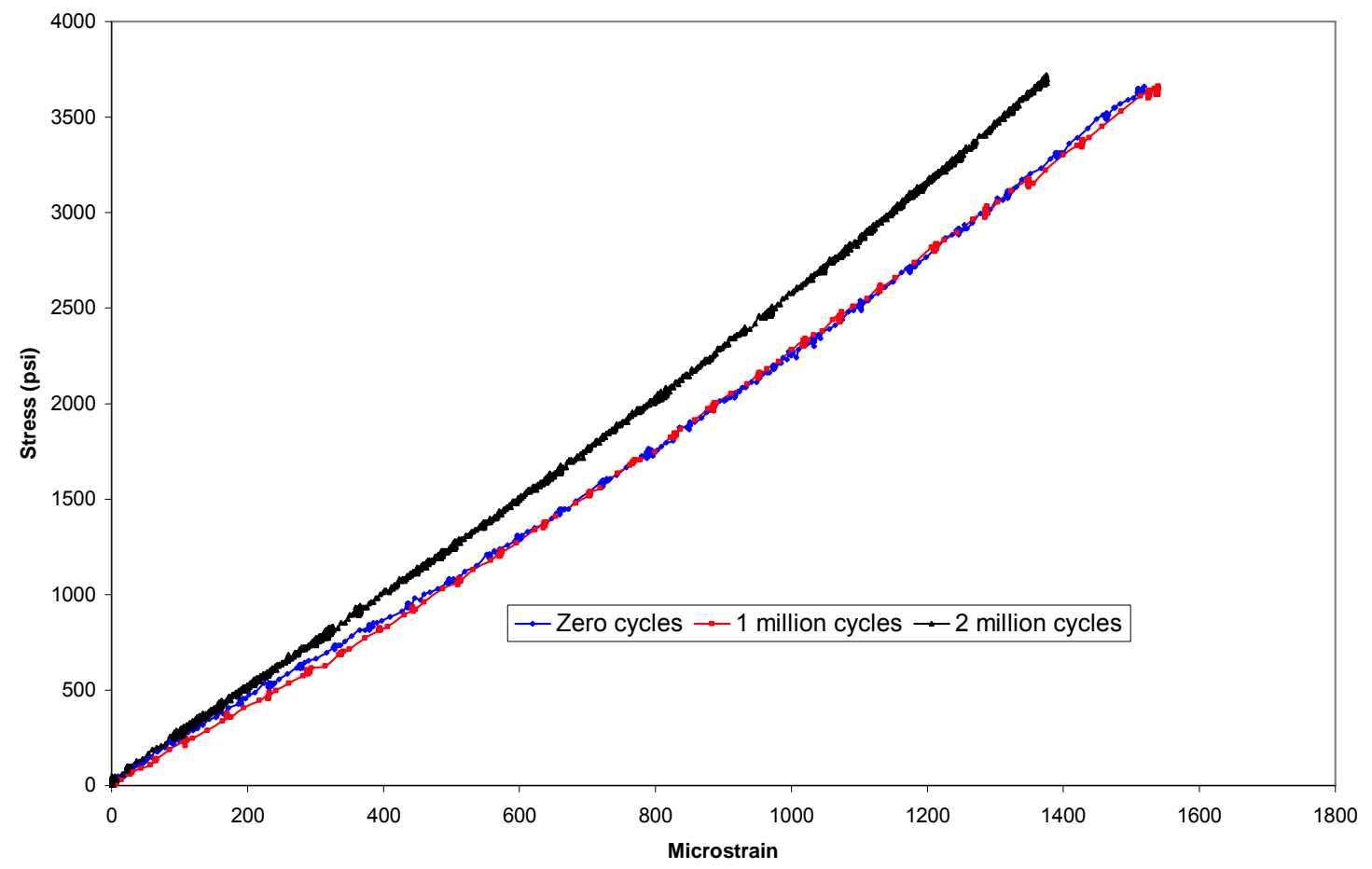

Figure 5.33 Tensile stress at bottom flange Vs strain for type II loading

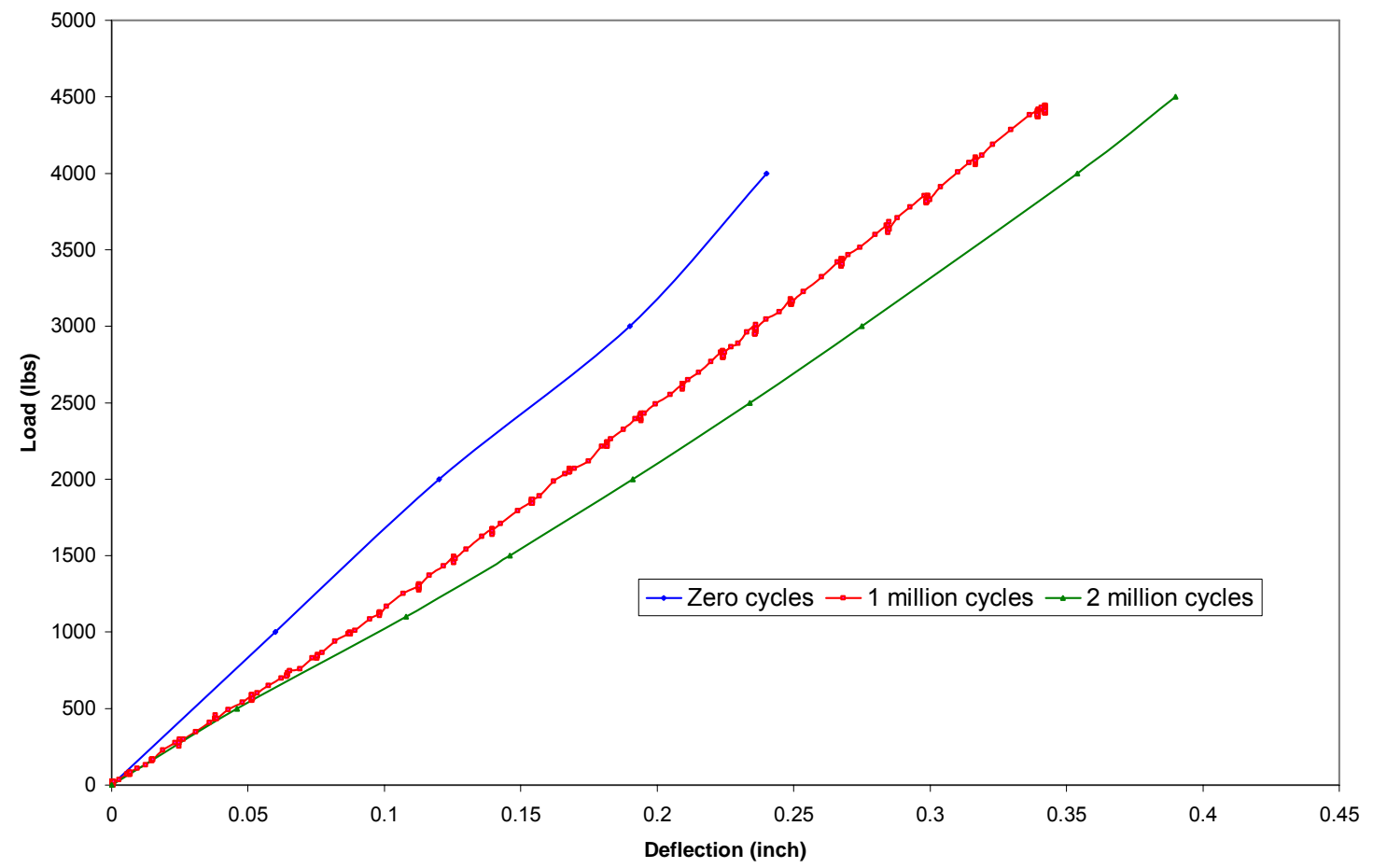

Figure 5.34 Load Vs deflection for type II loading 


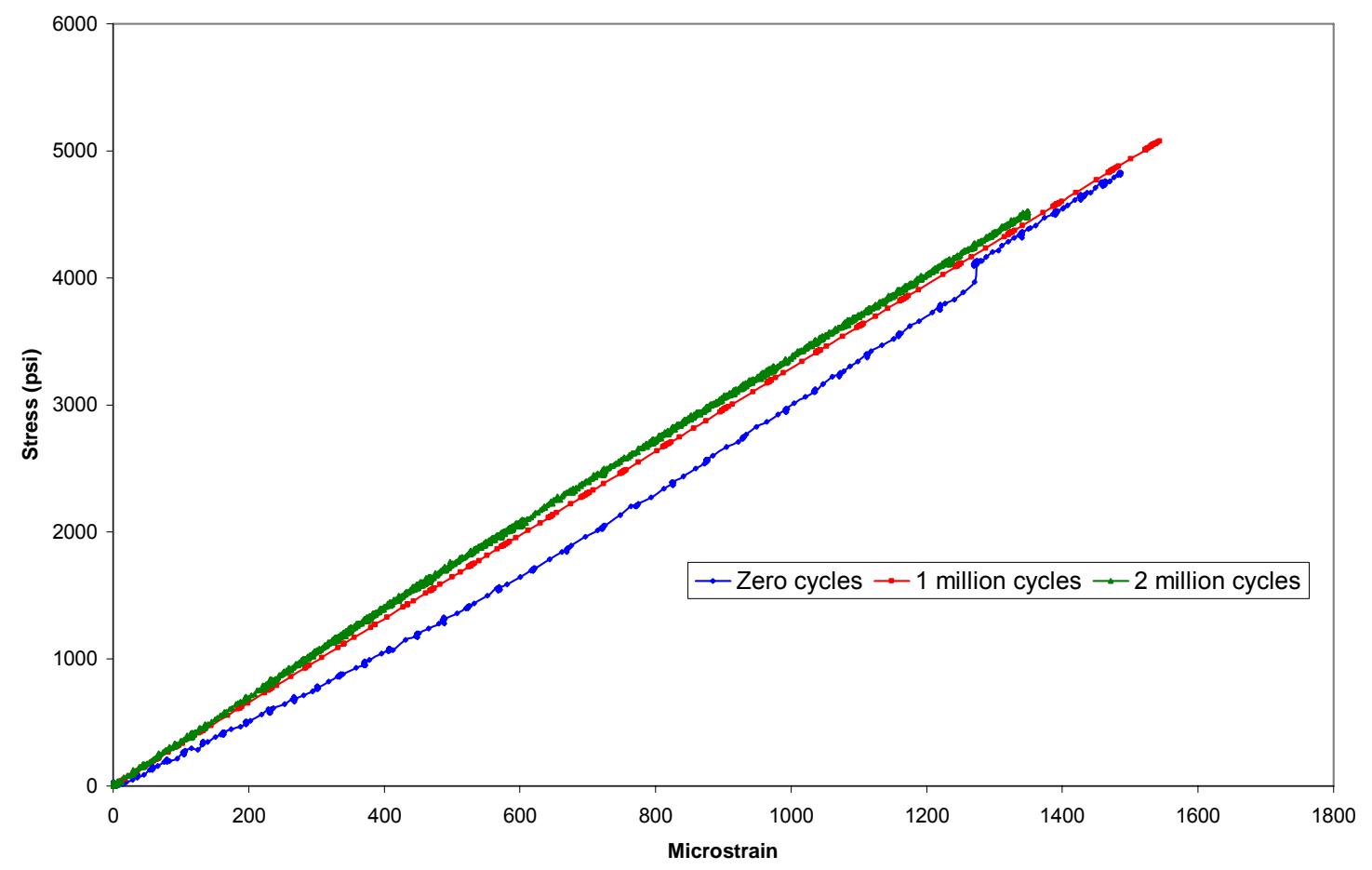

Figure 5.35 Tensile stress at bottom flange Vs strain for type III loading

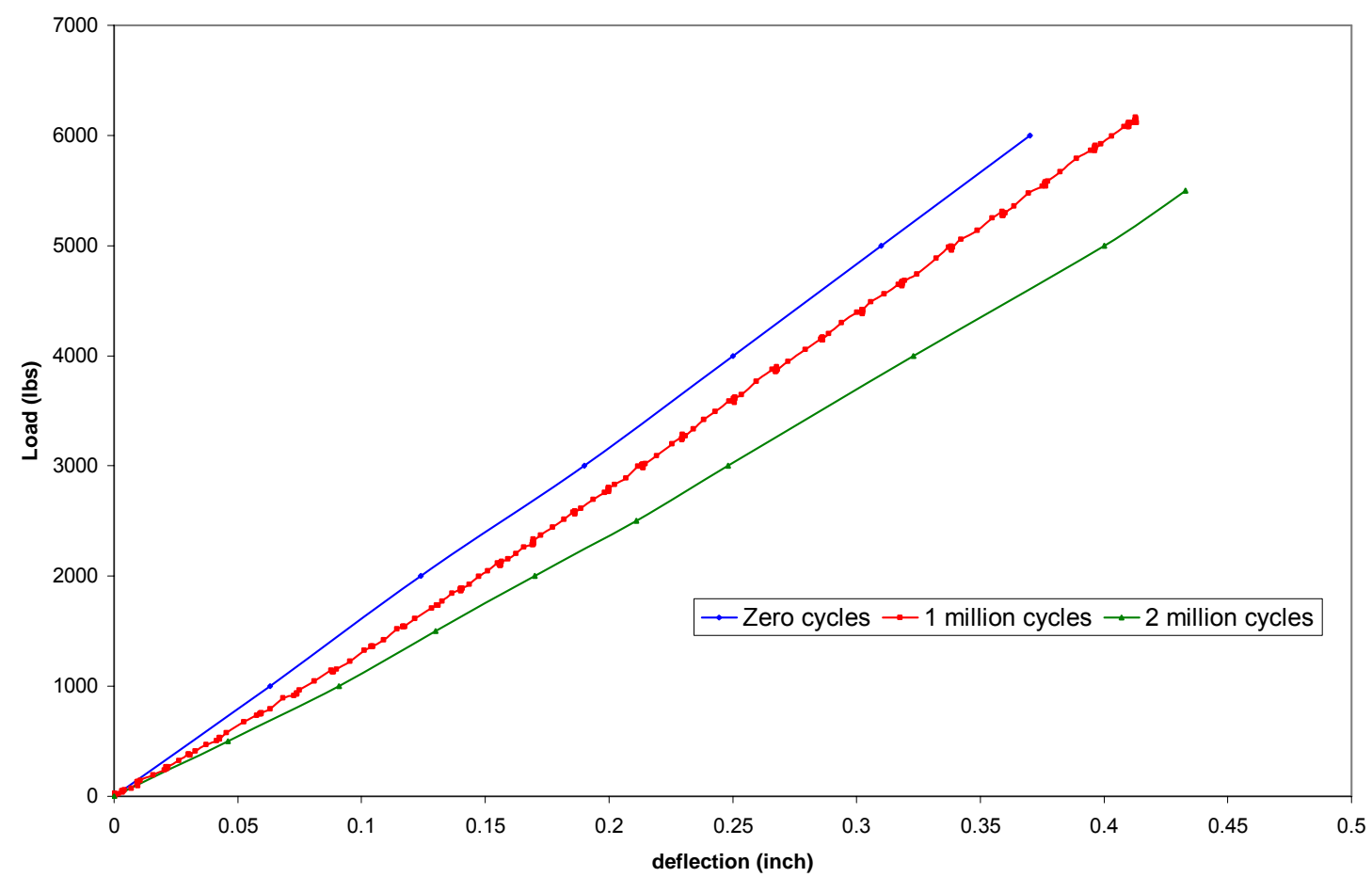

Figure 5.36 Load Vs deflection for Type III loading 


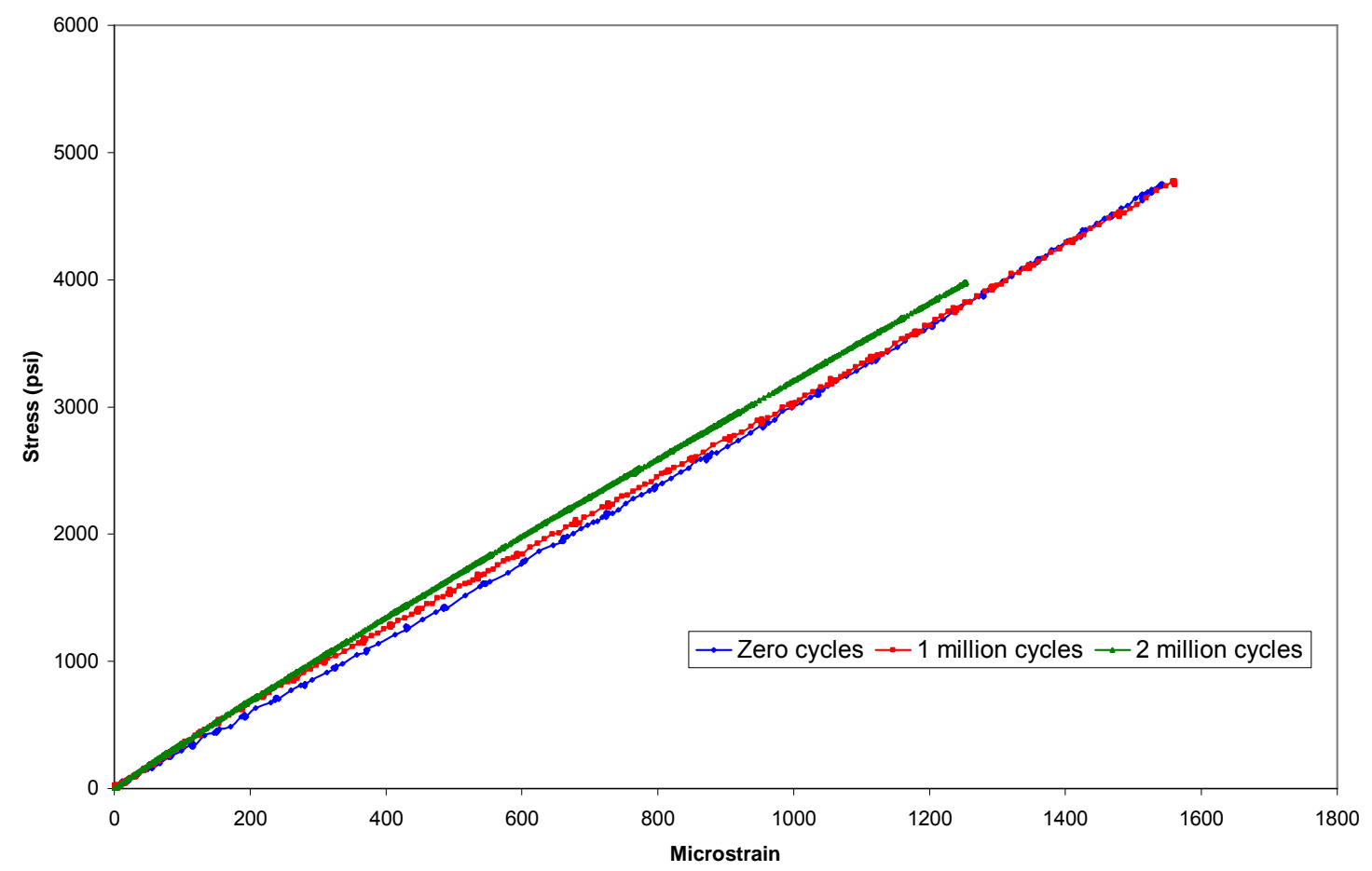

Figure 5.37 Tensile stress at bottom flange Vs strain for type IV loading

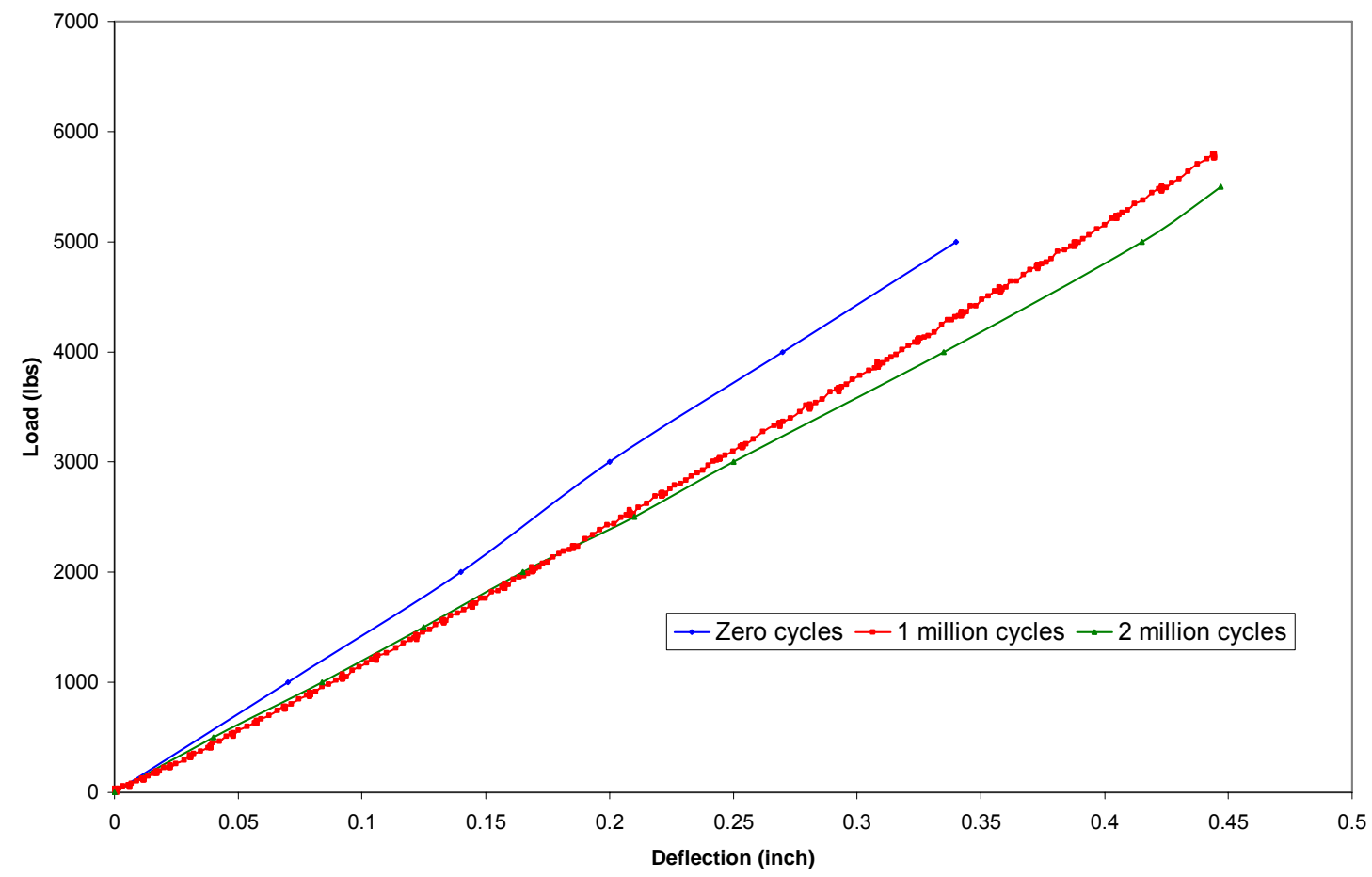

Figure 5.38 Load Vs deflection for type IV loading 


\section{Discussion of panel test Results:}

The following observations were inferred based on the panel test results:

I. Three point bending test results revealed that the panel provided highest stiffness of $3.3 \mathrm{msi}$ for Type II loading (Figure 5.30) when the traffic flow direction is perpendicular to the directions of webs.

II. The panel on gravel base was fatigued at $3 \mathrm{~Hz}$ frequency and a loading range of 4-23 kips with a gravel base under it. The cyclic loading was applied under the type III loading conditions i.e. glossy surface at bottom (directly touching the gravels of the bin) and 20 inch of the patch in the transverse direction. At specific intervals, the fatigue loading was stopped and static load was applied on the panel and strains at center of top and bottom flange were noted. At the end of 2 million fatigue cycles, strain at the top flange increased by about $8.5 \%$ and strain at the bottom increased by $23 \%$ as compared to the strain at zero fatigue cycles. Strain at center of bottom flange became almost constant ( 1800 Microstrain) after 200,000 cycles of fatigue loading and strain at center of top flange became almost constant ( 1900 Microstrain) after 50000 cycles of fatigue loading.

III. A sudden increase in the strain value was observed after 1 million fatigue cycles (Figure 5.39) which is attributed to cracking of temporary wooden supports provided between two webs of each cell, cracked and got displaced at some locations. Also, the accumulated resins at inside of the cells at bottom flange started to peel out from the cardboard tubes after 1 million fatigue cycles. Breaking/separating of these wooden supports and accumulated resins after 1 million cycles, resulted in a reduction of local panel stiffness the panel and an increase in the strain at top and bottom flanges when the panel was fatigued further to 2 million cycles, the strain values decreased again which is attributed to stress redistribution between flange and webs. 


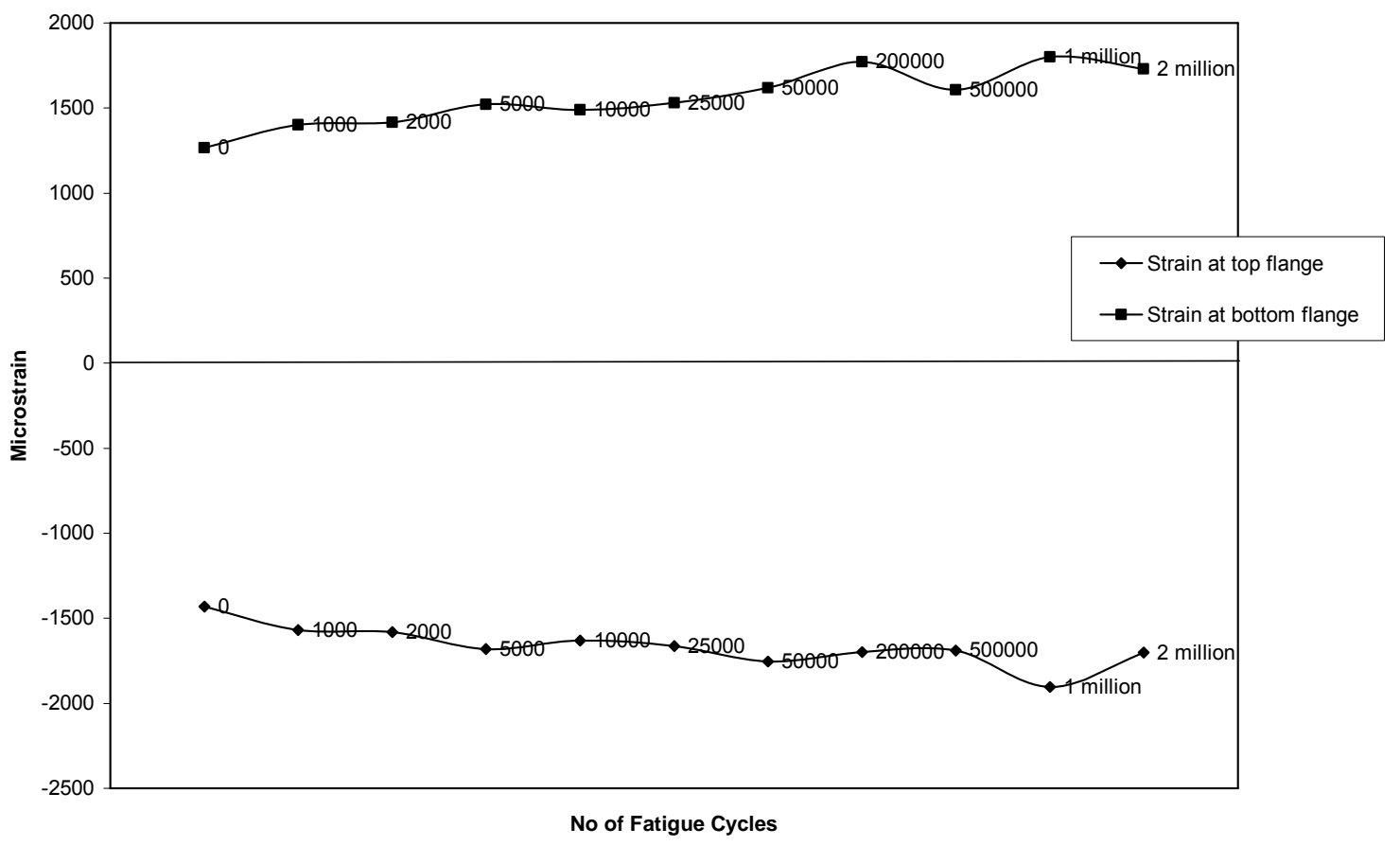

Figure 5.39 Top and bottom flange strains of FRP panel over a gravel base, under 23 klbs static loads

IV. Strains at the bottom and top flange of the panel varied from 1267-1800 Microstrain and 1432-1910 Microstrain respectively (Figure 5.39) under 23 klbs static loads. These strains were only $19 \%$ of the failure strain of coupon specimens from flange and webs of the panel, tested under tension and bending loads. Hence, panels are safe for field installation as a pavement structure.

V. The panel was taken out from the gravel bin after every 1 million fatigue cycles and tested under Types I, II, III and IV patch loading configurations. Table 5.13 presents, the stiffness value calculated from both stress-strain and load deflection data. From the stress-strain data, that the local stiffness of the panel remained almost unchanged even after 2 million fatigue cycles under 23 kips of static load. However, $20 \%$ reduction in panel global stiffness of the panel was observed from load-deflection data (Table 5.13, Figure 5.40). The 
stiffness reduction is attributed to fatigue induced deformations and stresses at web and flange intersections.

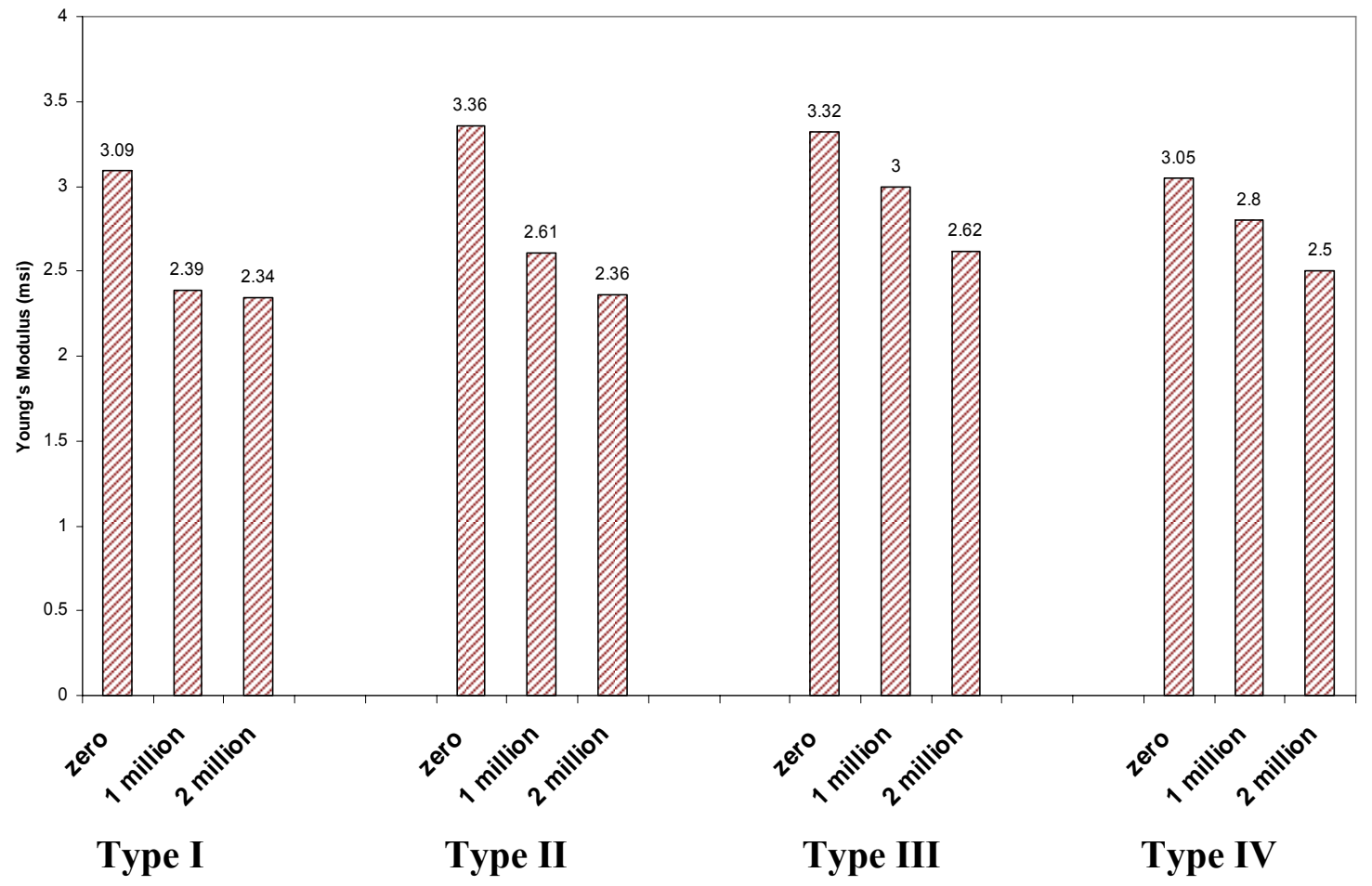

Figure 5.40 Young's moduli of the panel (calculated from load-deflection curve) subjected to fatigue

VI. Deflections of center cell of the gravel base supported FRP panel under 23 kips static load were measured using dial gages after every million fatigue cycles. Figure 5.41 shows the amount of compression of cells occurred under a static load of 23 kips after the panel was undergone a definite amount of fatigue cycles. Figure 5.41 shows that the compression of the cells increased about $13 \%$ after 1 million fatigue cycles. Compression of flange data was collected from zero to 2 million cyclic loading. 


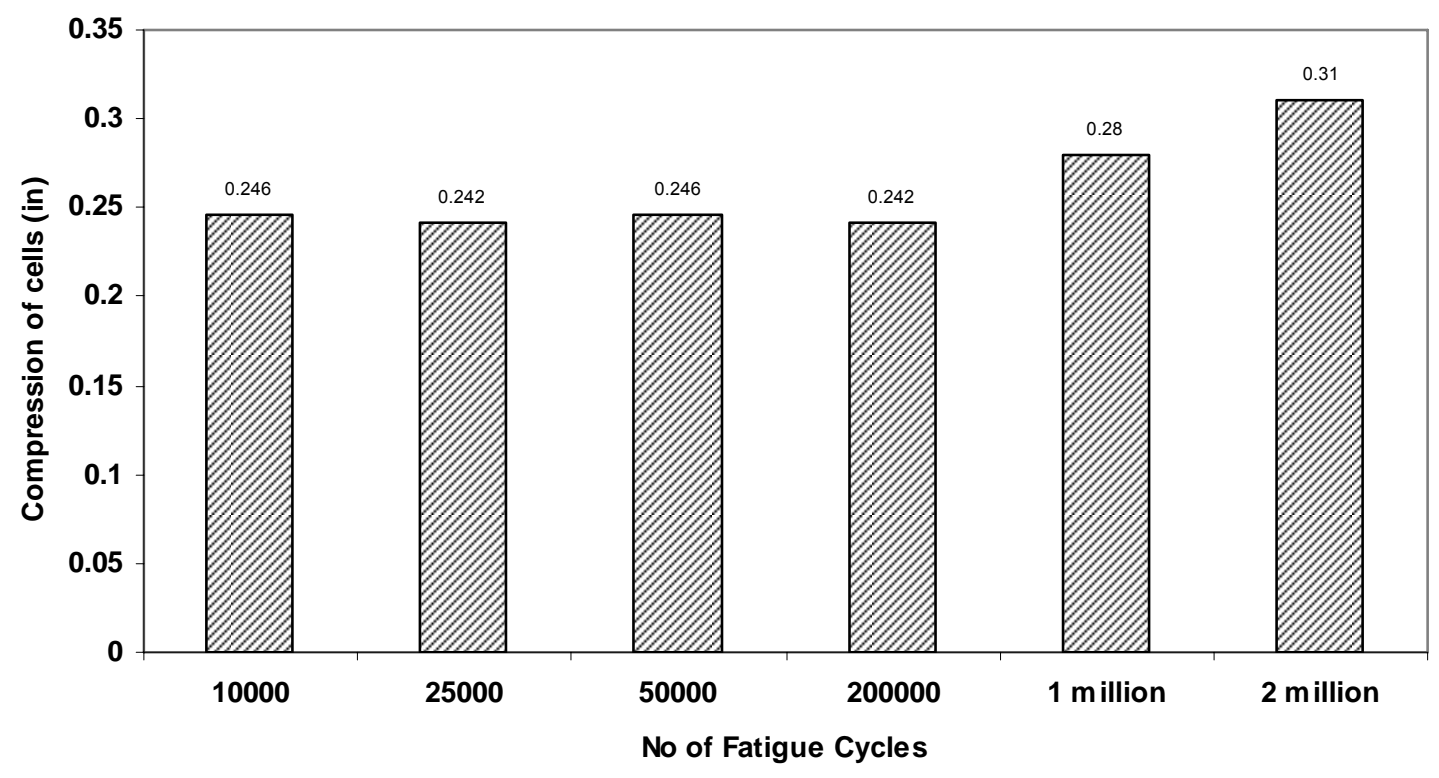

Figure 5.41 Compression of panel cells under 23 kips static load, measured after ' $N$ ' numbers of fatigue cycles (gravel base)

VII. The panel was tested to failure under patch loading with simply supported condition and a span of 84 inch after 2 million fatigue cycles. The panel did not show any visible cracking and noise levels even after a load of 50.3 kips corresponding $41.43 \mathrm{ksi}$ stress. The panel was not loaded further due to the load frame. When the load was released from 50.3 kips to zero, the panel came back to its original position and there was no permanent deformation in the panel.

\subsubsection{Test Panel Produced During Mass Production of the Actual Panel}

Tests were carried out on the test panel manufactured during mass production of actual panel, at coupon and component levels. Test results are discussed below.

\subsubsection{Burn out Test Results of Coupons}

Burn out test of specimen cut from webs and flanges were carried out. 
Table 5.14 Burn out test

\begin{tabular}{|l|l|l|l|l|l|l|l|}
\hline $\begin{array}{l}\text { Sample } \\
\text { No }\end{array}$ & $\begin{array}{l}\text { Length, } \\
\text { L (in) }\end{array}$ & $\begin{array}{l}\text { Breadth, } \\
\text { B (in) }\end{array}$ & $\begin{array}{l}\text { Thickness, } \\
\text { T (in) }\end{array}$ & $\begin{array}{l}\mathbf{W}_{\mathbf{C}} \\
(\mathbf{g m})\end{array}$ & $\begin{array}{l}\mathbf{W}_{\mathbf{f}+\mathbf{C}} \\
(\mathbf{g m}) \\
(\mathbf{b u r n})\end{array}$ & $\begin{array}{l}\text { L.B.T } \\
\text { (CC) }\end{array}$ & $\begin{array}{l}\text { FVF } \\
(\mathbf{\%})\end{array}$ \\
\hline $\mathbf{W}_{\mathbf{1}}$ & 1.03 & 1.029 & 0.322 & 19.63 & 24.17 & 5.57 & 32.3 \\
\hline $\mathbf{W}_{\mathbf{2}}$ & 1.011 & 1.018 & 0.314 & 19.16 & 23.50 & 5.29 & 32.5 \\
\hline $\mathbf{T F}_{\mathbf{1}}$ & 1.018 & 1.019 & 0.248 & 20.16 & 26.01 & 4.21 & 55.0 \\
\hline $\mathbf{T F}_{2}$ & 1.027 & 1.036 & 0.250 & 20.03 & 26.00 & 4.36 & 54.3 \\
\hline $\mathbf{B F}_{\mathbf{1}}$ & 1.047 & 1.05 & 0.240 & 19.17 & 25.20 & 4.31 & 55.5 \\
\hline $\mathbf{B F}_{\mathbf{2}}$ & 0.997 & 0.998 & 0.250 & 18.59 & 24.25 & 4.08 & 55.0 \\
\hline
\end{tabular}

Density of fiber $=2.522 \mathrm{gm} / \mathrm{cc}$.

$\mathrm{W}_{\mathrm{n}}: \mathrm{n}^{\text {th }}$ sample from web

$\mathrm{BF}_{\mathrm{n}}: \mathrm{n}^{\text {th }}$ sample from bottom flange

$\mathrm{TF}_{\mathrm{n}}: \mathrm{n}^{\text {th }}$ sample from top flange

\section{Discussion of burn out test results:}

The average fiber volume fraction at the web was 33\% and top and bottom flanges were $55 \%$. The resin infusion was quite uniform in both the top and bottom flanges. Webs had a lower fiber volume fraction i.e. more resin comparing to flanges. 


\subsubsection{Tension Test Results of Coupons}

Tension test results are discussed in this section. Table 5.15 presents the results of tension tests conducted on coupons cut from the flanges and the webs of the test panel produced during mass production of the actual panels by HT-VARIM process.

\section{Table 5.15 Tension test results}

\begin{tabular}{|c|c|c|c|c|c|c|c|c|c|c|c|}
\hline $\begin{array}{l}\text { Sample } \\
\text { No }\end{array}$ & $\begin{array}{l}\text { Average } \\
\text { FVF } \\
(\%)\end{array}$ & $\begin{array}{l}\text { Average } \\
\text { FVF(\%) } \\
\text { in } \\
\text { loading } \\
\text { direction }\end{array}$ & $\begin{array}{l}\text { Gage } \\
\text { Length } \\
\text { (in) }\end{array}$ & $\begin{array}{l}\text { Tab } \\
\text { Length } \\
\text { (in) }\end{array}$ & $\begin{array}{l}\text { Thickness } \\
\text { (in) }\end{array}$ & $\begin{array}{l}\text { Width } \\
\text { (in) }\end{array}$ & $\begin{array}{l}\text { Ultimate } \\
\text { Stress } \\
\text { (ksi) }\end{array}$ & $\begin{array}{l}\text { Strain at gage } \\
\text { failure } \\
\text { (micro) }\end{array}$ & $\begin{array}{l}\text { Stress } \\
\text { at gage } \\
\text { failure } \\
\text { (ksi) }\end{array}$ & $\begin{array}{l}\text { Average } \\
\text { Tension } \\
\text { Modulus } \\
\text { (msi) }\end{array}$ & $\begin{array}{l}\text { Normalized } \\
\text { Tensile } \\
\text { Stress (ksi) }\end{array}$ \\
\hline $\mathbf{B F}_{\mathbf{1}} \mathbf{P}_{\mathbf{t}}$ & \multirow{3}{*}{55} & \multirow{3}{*}{27.18} & 10 & 5 & 0.250 & 1.000 & 25.13 & 15814 & 25.13 & 3.16 & --- \\
\hline $\mathbf{B F}_{\mathbf{2}} \mathbf{P}_{\mathbf{t}}$ & & & 10 & 5 & 0.249 & 1.001 & 35.63 & 15350 & 35.63 & 2.64 & 131 \\
\hline $\mathbf{B F}_{\mathbf{3}} \mathbf{P}_{\mathbf{t}}$ & & & 10 & 5 & 0.250 & 0.998 & 35.92 & 12872 & 35.92 & 2.64 & 132 \\
\hline$T_{F} P_{1} P_{t}$ & \multirow{3}{*}{55} & \multirow{3}{*}{27.18} & 10 & 5 & 0.249 & 0.997 & 32.50 & 11050 & 32.50 & 2.89 & 120 \\
\hline $\mathbf{T F}_{\mathbf{2}} \mathbf{P}_{\mathbf{t}}$ & & & 10 & 5 & 0.248 & 0.996 & 31.23 & 14459 & 31.23 & 2.23 & 115 \\
\hline $\mathbf{T F}_{\mathbf{3}} \mathbf{P}_{\mathbf{t}}$ & & & 10 & 5 & 0.250 & 1.00 & 36.58 & 16534 & 36.58 & 2.48 & 135 \\
\hline $\mathbf{W}_{\mathbf{1}} \mathbf{P}_{\mathbf{t}}$ & \multirow{3}{*}{33} & \multirow{3}{*}{17.16} & 10 & 5 & 0.315 & 1.00 & 21.75 & 16505 & ----- & ---- & 127 \\
\hline $\mathbf{W}_{\mathbf{2}} \mathbf{P}_{\mathbf{t}}$ & & & 10 & 5 & 0.310 & 1.00 & 21.58 & 8112 & 21.58 & 2.63 & 126 \\
\hline $\mathbf{W}_{\mathbf{3}} \mathbf{P}_{\mathbf{t}}$ & & & 10 & 5 & 0.315 & .998 & 22.24 & 13519 & 21.30 & 1.90 & 131 \\
\hline
\end{tabular}

$\mathrm{TF}_{\mathrm{n}} \mathrm{P}_{\mathrm{t}}$ : Top flange $\mathrm{n}=1,2 \ldots$ numbered sample from panel for tension test

$\mathrm{BF}_{n} \mathrm{P}_{\mathrm{t}}$ : Bottom flange $\mathrm{n}=1,2 \ldots$ numbered sample from panel for tension test

$\mathrm{WF}_{\mathrm{n}} \mathrm{P}_{\mathrm{t}}$ : Web $\mathrm{n}=1,2 \ldots$ numbered sample from panel for tension test 


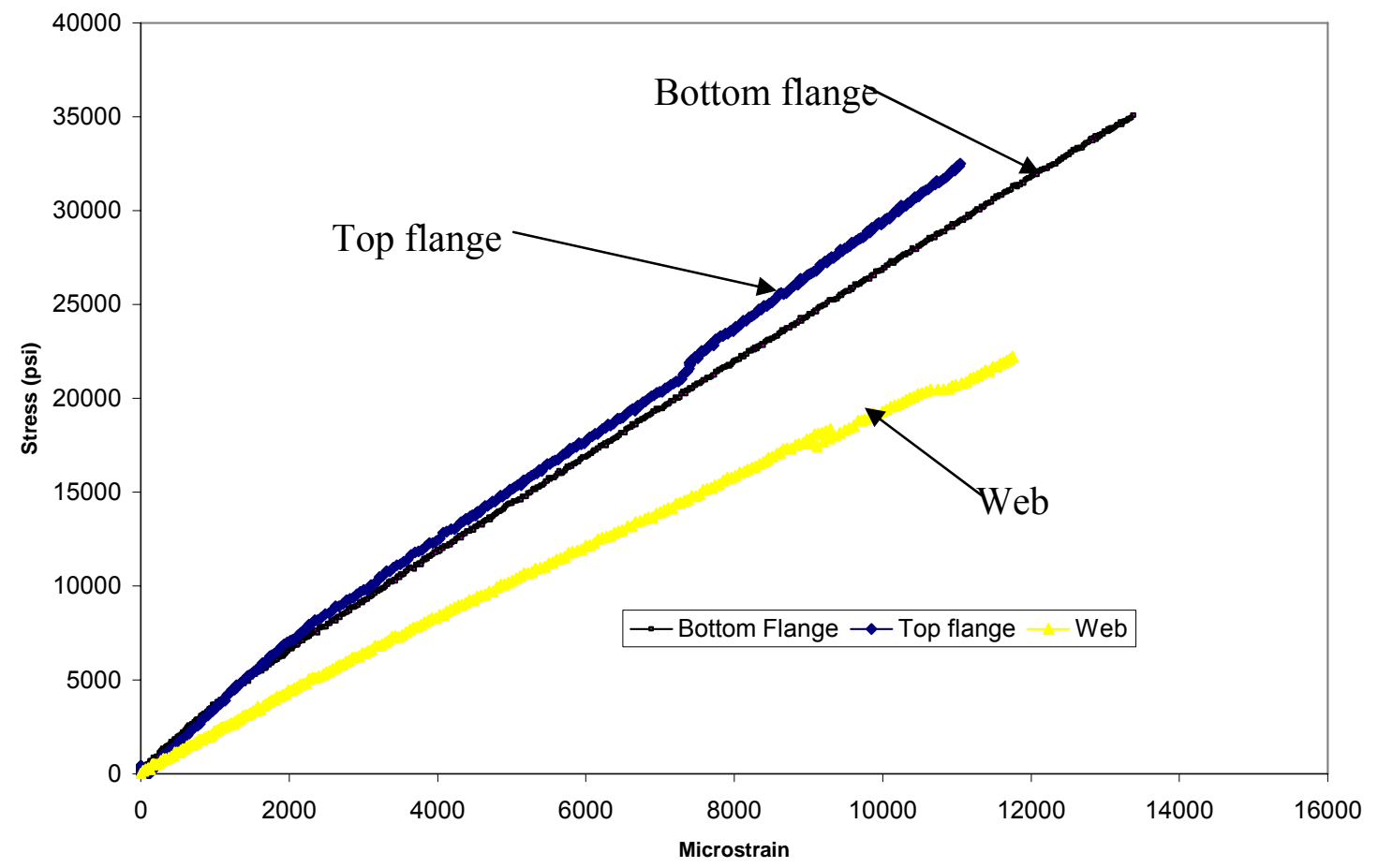

Figure 5.42 Stress-strain of specimens from web, top and bottom flange

\section{Discussion of tension test results:}

The following observations were noted:

I. Ultimate tensile stress of top and bottom flanges was $34.4 \mathrm{ksi}$ (Table 5.15). The ultimate tensile stress of web was $22 \mathrm{ksi}$. The tensile moduli of coupons from flanges and webs were 2.72 and 2.27 msi respectively.

II. Average strain to failure under tensile load was 14513 Microstrain.

III. Failure mode of the specimens consisted of glass fabric layer delamination attached with the cardboard. The coupon specimen preparation involved grinding off cardboard tubes from the places where the 5 inch long tabs were attached. While grinding off the cardboard, outermost fabric layer was partially grinded which resulted in tension failure initiated near the tab ends. This effect was more evident in case of coupon specimens cut from the webs of the panel, as those specimens had cardboard at both faces. Figure 5.42 shows the stress-strain curves of specimens cut from web, top and bottom flanges of the panel. 


\subsubsection{Bending Test Results}

This section discusses the bending test results.

Table 5.16 Four point bending test results

\begin{tabular}{|c|c|c|c|c|c|c|c|c|c|c|c|c|}
\hline \multirow[b]{2}{*}{$\begin{array}{l}\text { Sample } \\
\text { No }\end{array}$} & \multirow{2}{*}{$\begin{array}{l}\text { Average } \\
\text { FVF } \\
(\%)\end{array}$} & \multirow{2}{*}{$\begin{array}{l}\text { Average } \\
\text { FVF in } \\
\text { loading } \\
\text { direction } \\
(\%)\end{array}$} & \multirow[b]{2}{*}{ Span(in) } & \multirow[b]{2}{*}{ Width(in) } & \multirow[b]{2}{*}{$\begin{array}{l}\text { Thick- } \\
\text { ness(in) }\end{array}$} & \multirow{2}{*}{$\begin{array}{l}\text { Ultimate } \\
\text { Load } \\
\text { (lbs) }\end{array}$} & \multirow{2}{*}{$\begin{array}{l}\text { Ultimate } \\
\text { Stress } \\
\text { (ksi) }\end{array}$} & \multirow{2}{*}{$\begin{array}{l}\text { Gage } \\
\text { Failure } \\
\text { Strain } \\
\text { (micro) }\end{array}$} & \multirow{2}{*}{$\begin{array}{l}\text { Gage } \\
\text { Failure } \\
\text { stress } \\
\text { (ksi) }\end{array}$} & \multicolumn{2}{|c|}{$\begin{array}{l}\text { Bending Modulus } \\
\text { (msi) }\end{array}$} & \multirow{2}{*}{$\begin{array}{l}\text { Normalized } \\
\text { Bending } \\
\text { Stress (ksi) }\end{array}$} \\
\hline & & & & & & & & & & $\begin{array}{l}\text { From } \\
\text { Stress- } \\
\text { Strain }\end{array}$ & $\begin{array}{l}\text { From } \\
\text { Load- } \\
\text { Deflection } \\
\end{array}$ & \\
\hline $\mathbf{B F}_{\mathbf{1}} \mathbf{P}_{\mathrm{b}}$ & \multirow{3}{*}{55} & \multirow{3}{*}{27.18} & 6 & 1.018 & 0.249 & 467 & 44.35 & 15821 & 44.35 & 2.93 & 3.35 & 163 \\
\hline $\mathbf{B F}_{2} \mathbf{P}_{b}$ & & & 6 & 1.015 & 0.246 & 608 & 59.40 & 16823 & 59.40 & 3.50 & 3.52 & 218 \\
\hline $\mathbf{B F}_{3} \mathbf{P}_{b}$ & & & 6 & 0.985 & 0.250 & 408 & 39.80 & 15456 & 39.80 & 2.50 & 2.84 & 146 \\
\hline $\mathbf{T F}_{\mathbf{1}} \mathbf{P}_{\mathrm{b}}$ & \multirow{3}{*}{55} & \multirow{3}{*}{27.18} & 6 & 1.014 & 0.250 & 489 & 46.25 & 15540 & 46.25 & 2.99 & 3.06 & 170 \\
\hline $\mathbf{T F}_{2} \mathbf{P}_{\mathbf{b}}$ & & & 6 & 1.016 & 0.249 & 375 & 35.72 & 13890 & 35.72 & 2.57 & 3.16 & 131 \\
\hline $\mathbf{T F}_{3} \mathbf{P}_{\mathrm{b}}$ & & & 6 & 0.986 & 0.248 & 250 & 24.74 & 12360 & 24.74 & 2.00 & 2.68 & ---- \\
\hline $\mathbf{W}_{1} \mathbf{P}_{b}$ & \multirow{2}{*}{33} & \multirow{2}{*}{17.16} & 6 & 1.014 & \begin{tabular}{|l|}
0.320 \\
\end{tabular} & 387 & 22.40 & 15697 & 22.40 & 1.46 & ------ & 130 \\
\hline $\mathbf{W}_{2} \mathbf{P}_{b}$ & & & 6 & 1.003 & 0.314 & 389 & 23.60 & 15600 & 23.60 & 1.51 & 1.64 & 138 \\
\hline
\end{tabular}

$\mathbf{T F}_{\mathbf{n}} \mathbf{P}_{\mathbf{b}}$ : Top flange $\mathrm{n}=1,2 \ldots$ numbered sample from panel for bending test

$\mathbf{B F}_{\mathbf{n}} \mathbf{P}_{\mathbf{b}}$ : Bottom flange $\mathrm{n}=1,2 \ldots$ numbered sample from panel for bending test

$\mathbf{W F}_{\mathbf{n}} \mathbf{P}_{\mathbf{b}}$ : Web $n=1,2 \ldots$ numbered sample from panel for bending test 


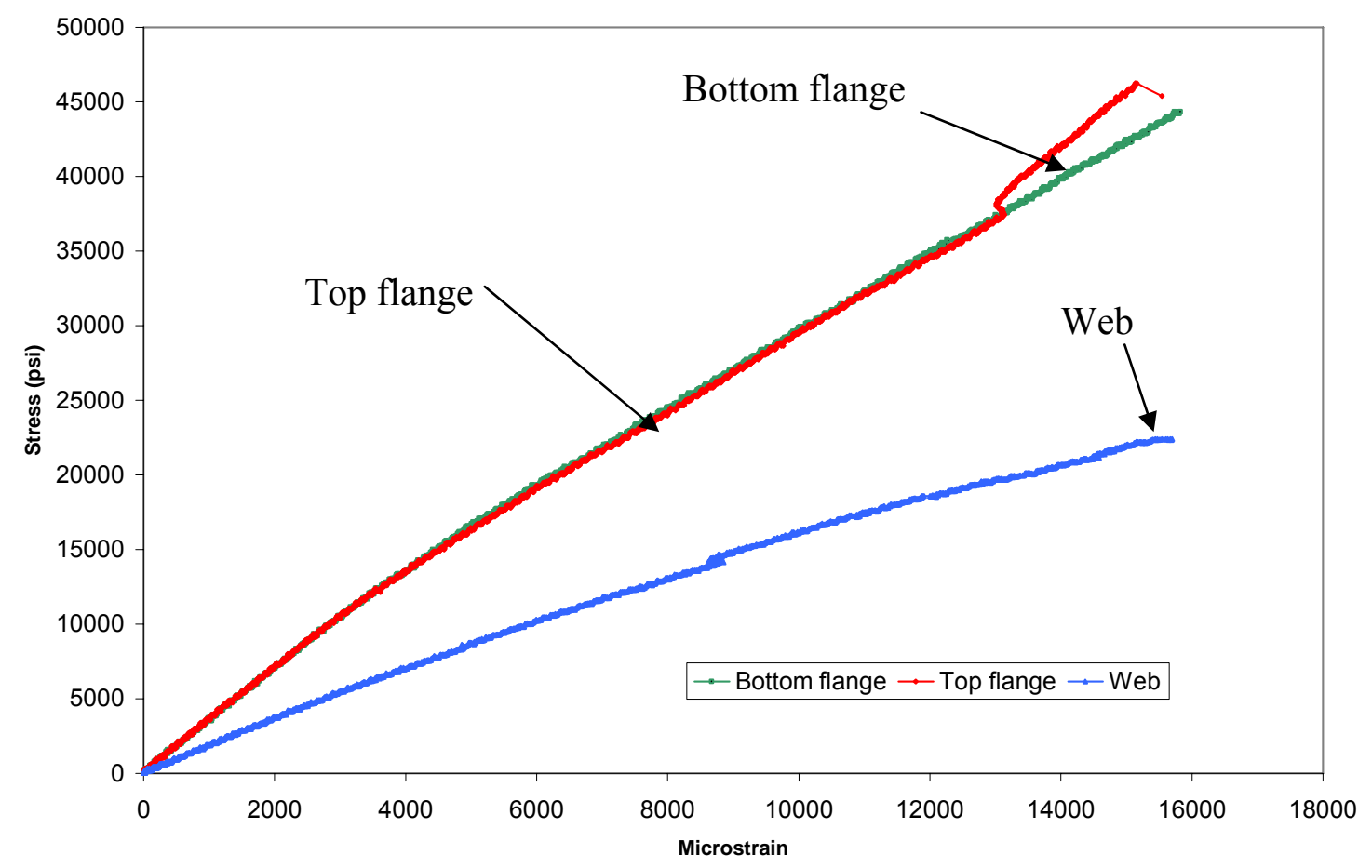

Figure 5.43 Stress-strain of specimen from web, top and bottom flange, under four point bending

\section{Discussion of four point bending test results:}

The following observations were noted:

IV. Ultimate bending stress of top and bottom flanges was $42.0 \mathrm{ksi}$ (Table 5.16). The ultimate tensile stress of web was $24 \mathrm{ksi}$. The bending moduli of coupons from flanges and webs were 2.75 and 1.5 msi respectively.

V. Average strain to failure under tensile load was 13300 Microstrain.

VI. Bending properties of the coupon specimens have high scatter which is attributed to variation in specimen cutting locations of the panel. It was very difficult to maintain certain kind of uniformity while cutting the specimens because of the presence of stapler pins at certain locations. The webs coupon specimens have lower ultimate bending stress and bending modulus than those of the flanges, because of lower fiber volume fraction and removing the cardboards from one side as explained in section 5.3.3.2. Figure 5.43 shows 
the stress-strain curves of coupon specimens under four point bending from web, top flange and bottom flange.

\subsubsection{Short Beam Shear Test}

Table 5.17 presents the short beam shear test results.

Table 5.17 Short beam shear test results

\begin{tabular}{|c|c|c|c|c|c|c|c|c|}
\hline \multirow[b]{2}{*}{ Specimen } & \multicolumn{3}{|c|}{ Dimension } & \multirow[b]{2}{*}{$S / t$} & \multirow[b]{2}{*}{$\begin{array}{l}\text { Area } \\
\left(\text { in }^{2}\right)\end{array}$} & \multirow[b]{2}{*}{$\begin{array}{l}\text { Maximum } \\
\text { Load (lbs) }\end{array}$} & \multirow{2}{*}{$\begin{array}{l}\text { Average } \\
\text { Shear Stress } \\
\text { (ksi) }\end{array}$} & \multirow[b]{2}{*}{$\begin{array}{l}\text { Mode of } \\
\text { failure }\end{array}$} \\
\hline & $\begin{array}{l}\text { (in) } \\
\text { (in }\end{array}$ & $\begin{array}{l}\text { B } \\
\text { (in) }\end{array}$ & $\begin{array}{l}\mathbf{t} \\
\text { (in) }\end{array}$ & & & & & \\
\hline $\mathbf{T F}_{1} \mathbf{P}_{\mathrm{sb}}$ & 1 & 0.5 & 0.249 & 4 & 0.125 & 796 & 4.80 & \multirow{7}{*}{ Delaminating } \\
\hline $\mathbf{T F}_{2} \mathbf{P}_{\mathbf{s b}}$ & 1 & 0.5 & 0.25 & 4 & 0.125 & 836 & 5.03 & \\
\hline $\mathbf{B F}_{1} \mathbf{P}_{\mathbf{s b}}$ & 1 & 0.5 & 0.25 & 4 & 0.125 & 856 & 5.18 & \\
\hline $\mathbf{B F}_{2} \mathbf{P}_{\mathrm{sb}}$ & 1 & 0.5 & 0.25 & 4 & 0.125 & 809 & 4.88 & \\
\hline $\mathbf{B F}_{3} \mathbf{P}_{\mathbf{s b}}$ & 1 & 0.5 & 0.25 & 4 & 0.125 & 846 & 5.10 & \\
\hline $\mathbf{W F}_{1} \mathbf{P}_{\mathbf{s b}}$ & 1 & 0.5 & 0.314 & 3.23 & 0.157 & 872 & 4.20 & \\
\hline $\mathbf{W F}_{2} \mathbf{P}_{\mathrm{sb}}$ & 1 & 0.5 & 0.309 & 3.24 & 0.155 & 856 & 4.13 & \\
\hline
\end{tabular}

$\mathrm{TF}_{\mathrm{n}} \mathrm{P}_{\mathrm{sb}}$ : Top flange $\mathrm{n}=1,2 \ldots$ numbered sample from panel for short beam test

$\mathrm{BF}_{\mathrm{n}} \mathrm{P}_{\mathrm{sb}}$ : Bottom flange $\mathrm{n}=1,2 \ldots$ numbered sample from panel for short beam test

$\mathrm{WF}_{\mathrm{n}} \mathrm{P}_{\mathrm{sb}}$ : Web $\mathrm{n}=1,2 \ldots$ numbered sample from panel for short beam test

\section{Discussion of test results:}

Average ultimate shear stress was found to be $5 \mathrm{ksi}$ for specimens cut from the flange and $5.55 \mathrm{ksi}$ for specimens cut from the web.

\subsubsection{Three Point Bending Test of Test Panel Produced Through Mass Production Process}

Table 5.18 presents the bending test results of the test panel produced during the mass production of the actual panel. 
Table 5.18 Three point bending test results of panel

\begin{tabular}{|c|c|c|c|c|c|c|c|}
\hline \multirow[b]{2}{*}{$\begin{array}{l}\text { No of } \\
\text { Cycles }\end{array}$} & \multirow{2}{*}{$\begin{array}{c}\text { Loading } \\
\text { Type } \\
\\
\text { (Ref. } \\
\text { Fig. } \\
\text { 5.30) }\end{array}$} & \multirow[b]{2}{*}{$\begin{array}{c}\text { Span } \\
\text { (in) }\end{array}$} & \multirow[b]{2}{*}{$\begin{array}{l}\text { Moment } \\
\text { of inertia } \\
\quad\left(\text { in }^{4}\right)\end{array}$} & \multirow{2}{*}{$\begin{array}{c}\text { Slope of } \\
\text { Load Vs } \\
\text { Deflection } \\
\text { Curve } \\
(\mathrm{P} / \delta)\end{array}$} & \multirow{2}{*}{$\begin{array}{c}\text { E Values } \\
\text { (msi) } \\
\text { (Compressio } \\
\text { n Flange) }\end{array}$} & \multicolumn{2}{|c|}{$\begin{array}{c}\text { E values (msi) } \\
\text { (Tension Flange) }\end{array}$} \\
\hline & & & & & & $\begin{array}{c}\text { From } \\
\text { Stress } \\
\text { Strain } \\
\text { Data }\end{array}$ & $\begin{array}{c}\text { From } \\
\text { Load- } \\
\text { Deflection } \\
\text { Data (not } \\
\text { adjusted } \\
\text { for shear) }\end{array}$ \\
\hline \multirow{4}{*}{$\begin{array}{l}\text { Zero } \\
\text { Cyclic } \\
\text { Loading }\end{array}$} & I & 84 & 23.4 & 6236 & 4.85 & 4.12 & 3.29 \\
\hline & II & 84 & 23.4 & 6701 & 5.04 & 4.48 & 3.54 \\
\hline & III & 84 & 23.4 & 6291 & ---- & 4.58 & 3.32 \\
\hline & IV & 84 & 23.4 & 6782 & 3.99 & 3.10 & 3.58 \\
\hline $\begin{array}{l}1 \text { Million } \\
\text { Cyclic } \\
\text { Loading }\end{array}$ & I & 84 & 23.4 & 5691 & 3.76 & 2.57 & 3.00 \\
\hline $\begin{array}{l}2 \text { Million } \\
\text { Cyclic } \\
\text { Loading }\end{array}$ & I & 84 & 23.4 & 5409 & 3.70 & 2.87 & 2.86 \\
\hline
\end{tabular}

\section{Discussion of test results:}

Following observations were made from the test results:

I. After 1 million cyclic loading, strains at the top and bottom flange of the panel were almost constant (Figure 5.44) at 23 kips of static load applied on the panel placed over the gravel base. 


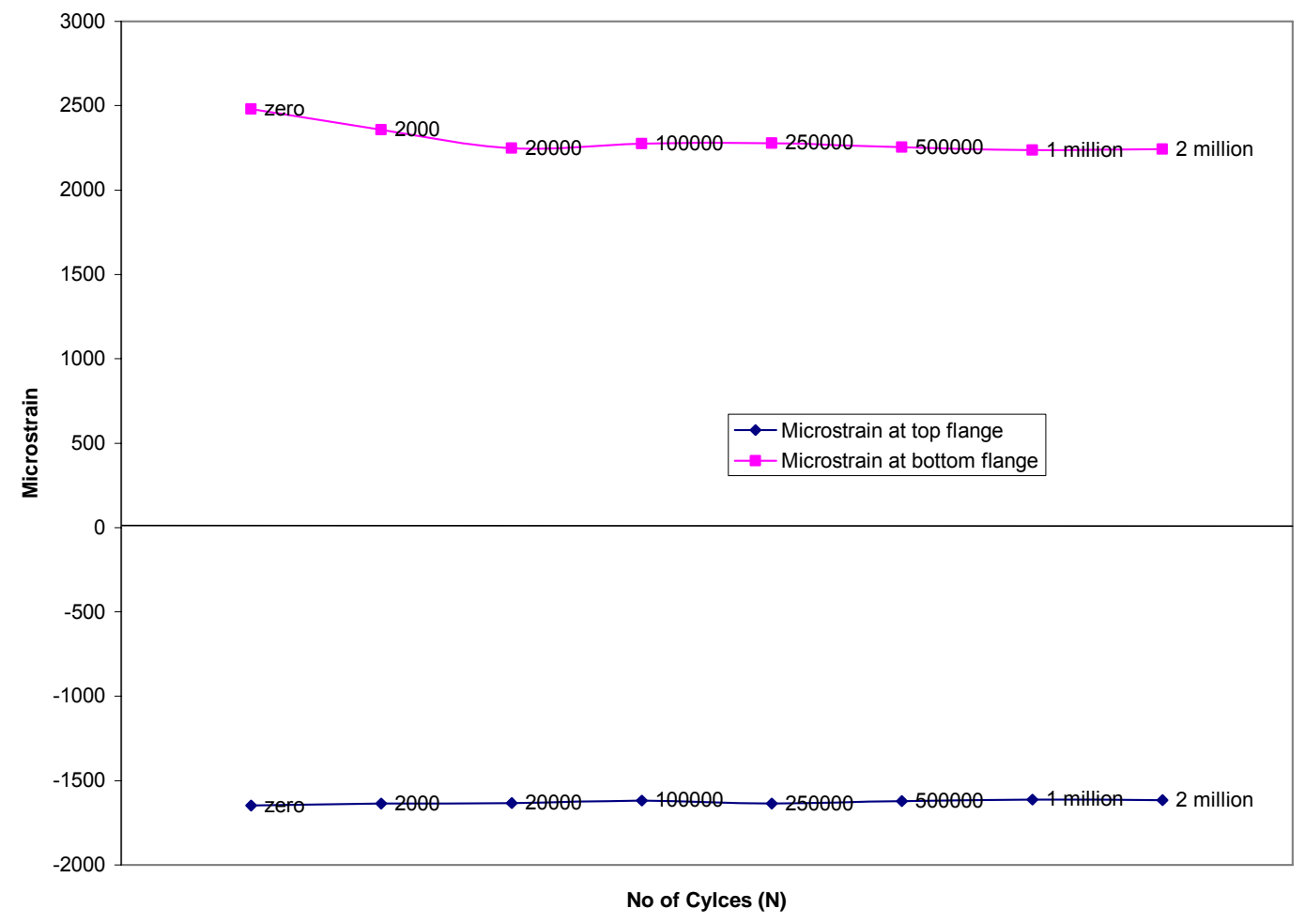

Figure 5.44 Variation of strain Vs ' $N$ ' fatigue cycles

The strains at bottom and top flanges ranged from 2238-2480 Microstrain and 1611-1649 Microstrain, respectively. These strains were only about 19\% of ultimate failure strain obtained from coupon tension and bending test. The panel can safely withstand the stresses induced in the pavement structure.

II. The bending modulus of the panel when tested under patch loading, decreased by about $20 \%$ after 2 million fatigue cycles. As observed in phase II experiments, the panel provided highest stiffness when the traffic flow was in a direction perpendicular to the webs (Type II and IV).

III. The panel was fatigued over a gravel base and then tested under static load. Deflection profile of the panel is shown in Figure 5.45. At 2 kips load, the panel deflection at its geometric center (i.e. $4 \mathrm{ft}$ from left end in Figure 5.45) is lower than those at $2 \mathrm{ft}$ and $6 \mathrm{ft}$ from one end. During initial load application, the load was primarily carried by adjacent webs and eventually it was uniformly distributed among the flange and webs with increasing load. As 
the load was increased, both ends of the panel showed a tendency to lift up at a distance of $3 \mathrm{ft}-4 \mathrm{ft}$ from center where the load was applied. Based on the result it is recommended to anchor the panels at a spacing of $3 \mathrm{ft}-4 \mathrm{ft}$ when installed as pavement structures.

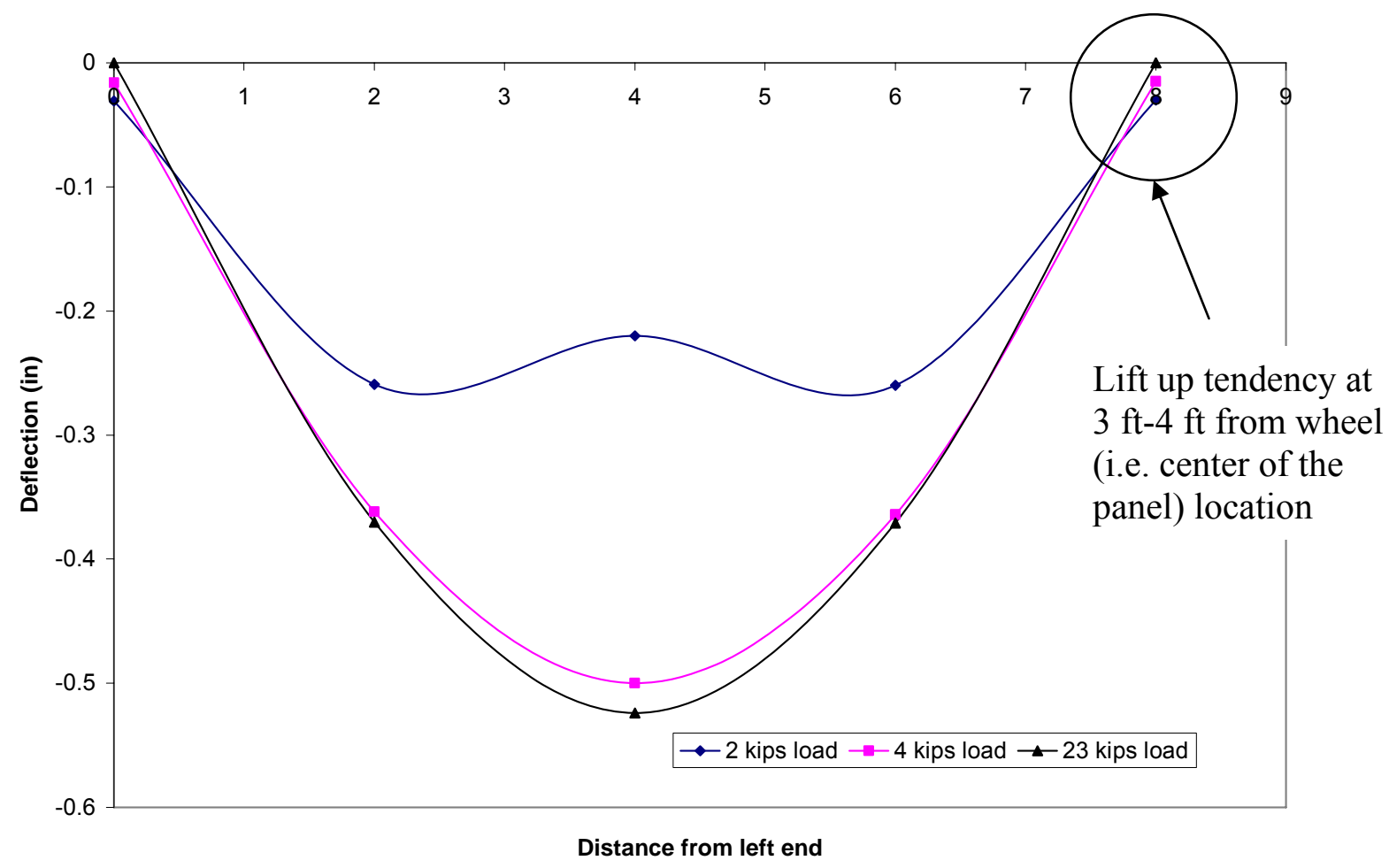

Figure 5.45 Deflection profile of the panel under static load with a gravel base

\subsubsection{Patch Loading with Two Feet Span}

In the field, the panel can be subjected to bending or shear forces with sub-base cavitations due to localized movement or settlement at some location as shown in Figure 5.47. In order to simulate this condition in the laboratory, the panel was tested with a span of $2 \mathrm{ft}$ with strain gages attachment. Strain gages are attached at the center of top and bottom flanges as well as an exterior and an interior web (Figure 5.49). The panel was tested for base cavitations with a span of 30 inch at one million and two million fatigue cycles. 


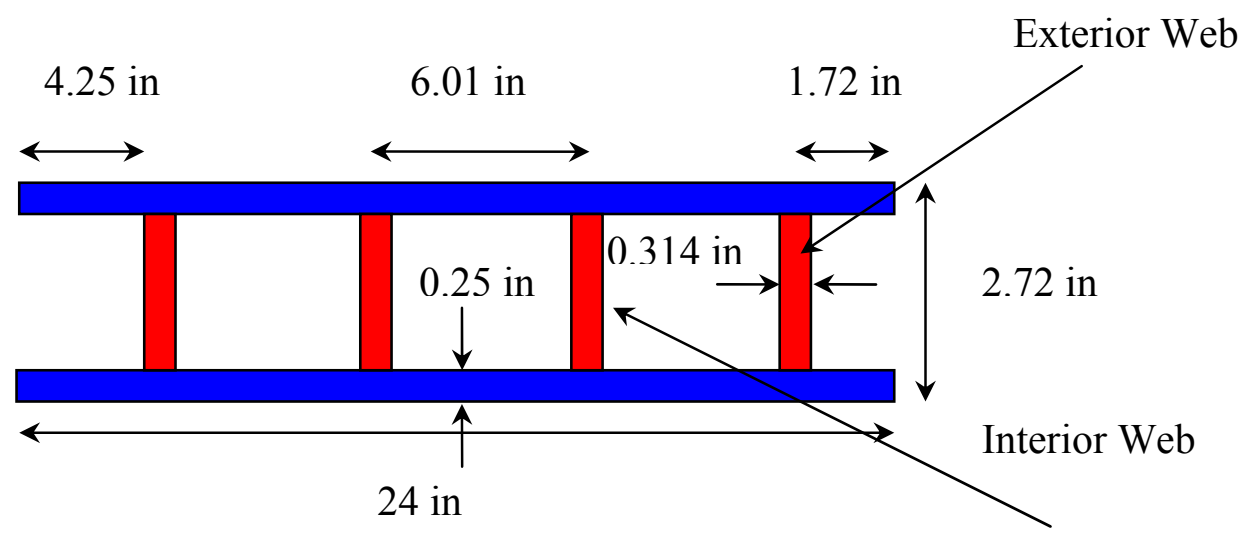

Figure 5.46 Cross section of the test panel

Cellular Panel

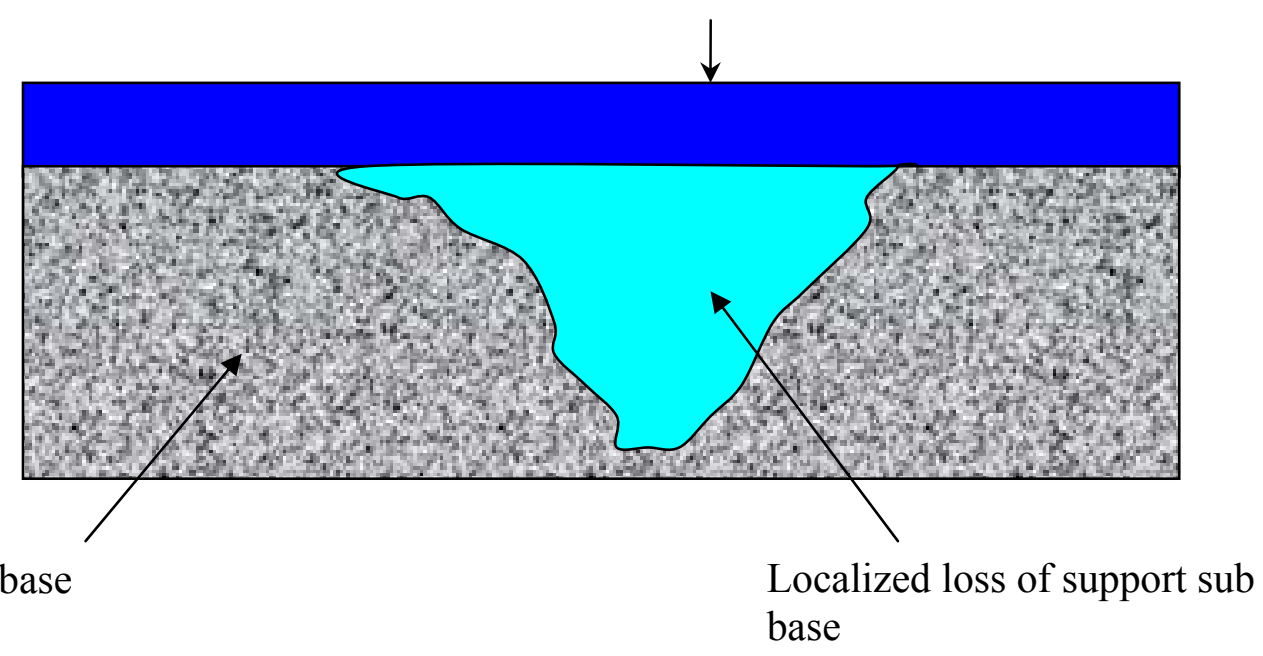

Figure 5.47 Field condition showing a pavement panel without partial subbase support 


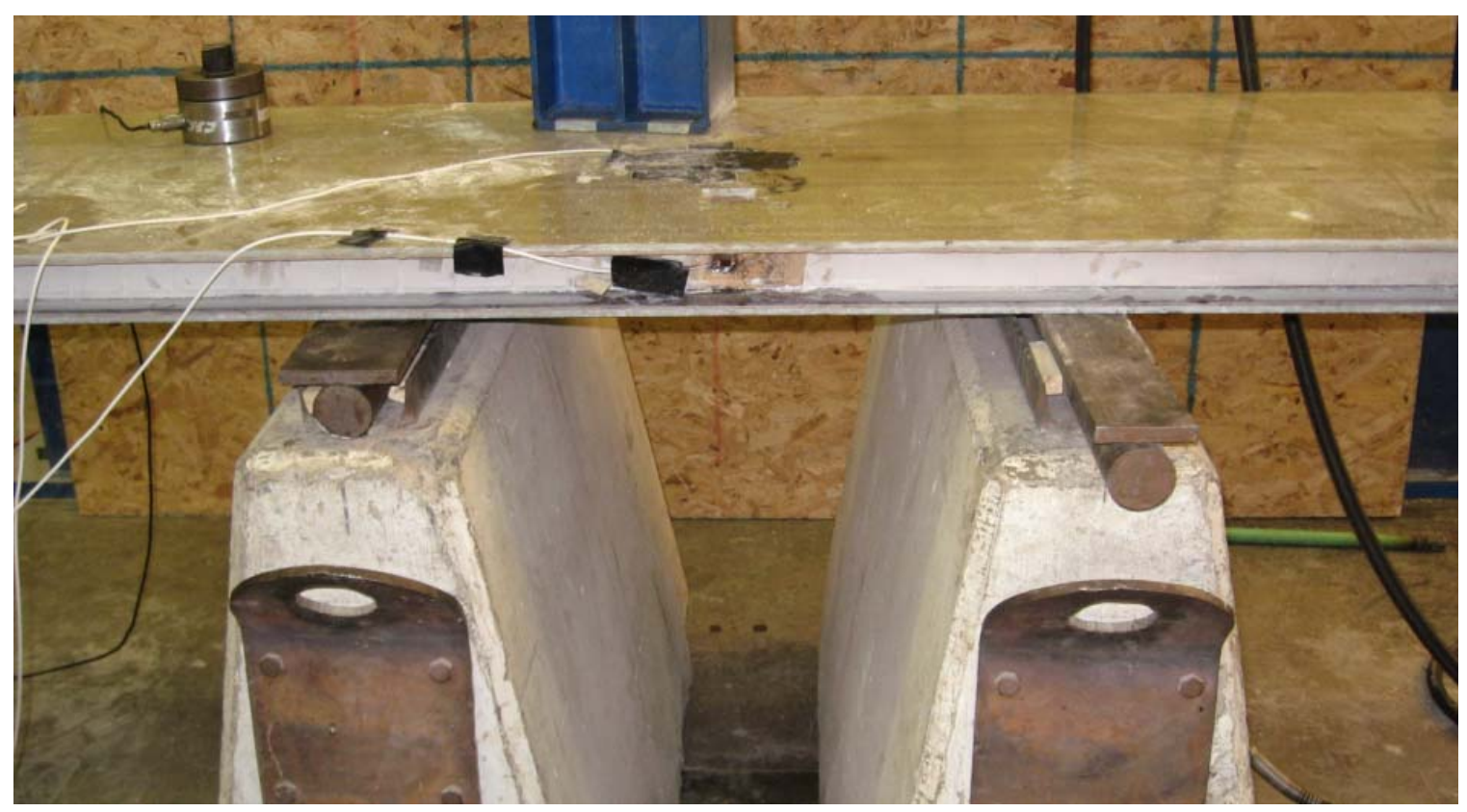

Figure 5.48 Panel was tested with $2 \mathrm{ft}$ span under 10 inch $\times 20$ inch patch loading

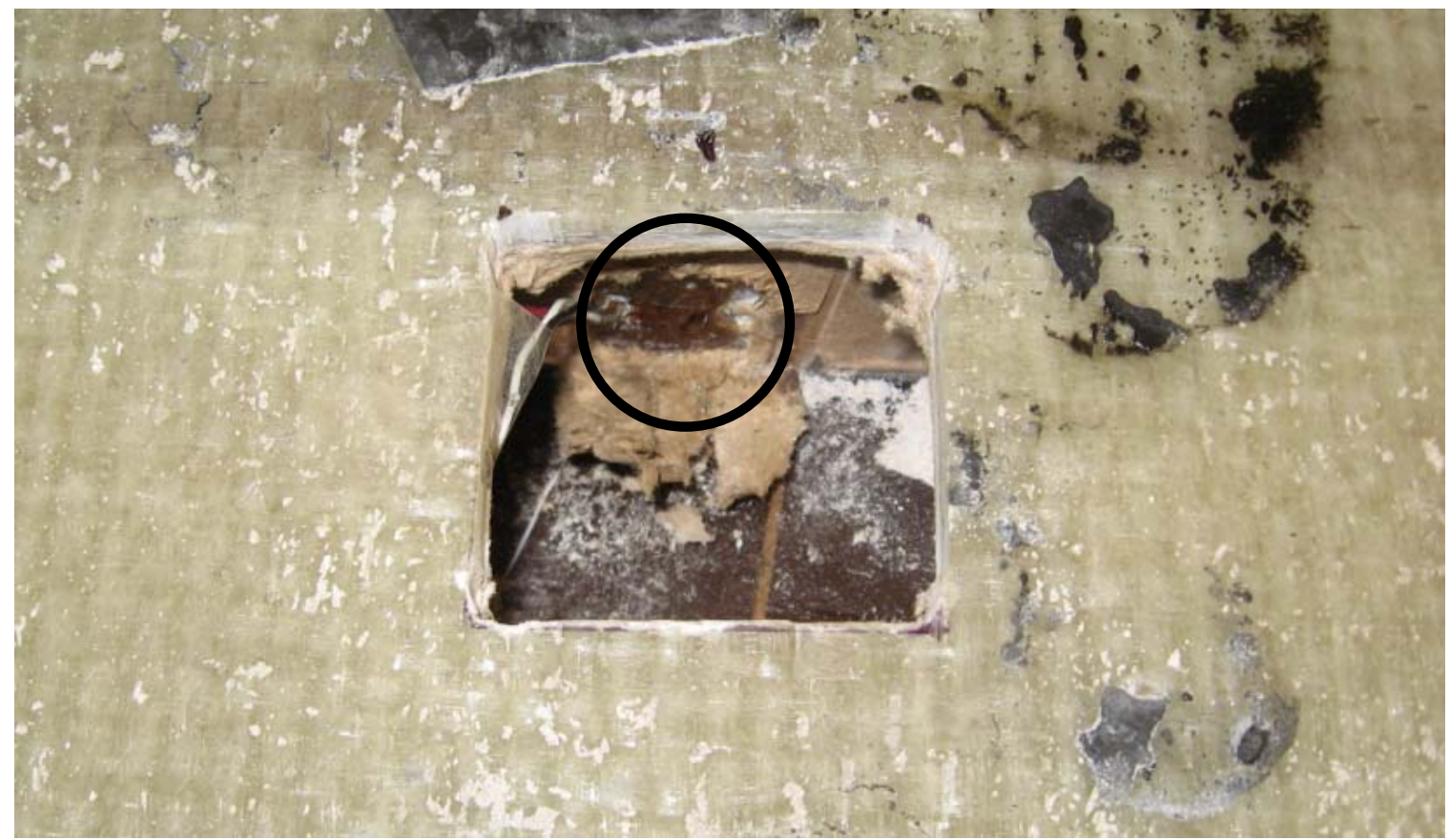

Figure 5.49 Strain gage at the interior web attached after cutting a 2 inches $x 2$ inches hole in the top flange 


\section{Discussion of the test results:}

Test results and their discussions are provided in this section:

I. The strain gage at the center web was attached by cutting a 2 inches $\mathrm{x} 2$ inches hole at the top flange as shown in Figure 5.49. The load Vs strain plots of the panel under patch load of 10 inch x 20 inch are shown in Figures 5.50 and 5.51. The bottom and top flange strain at 23 kips load were 2370 and 1880 Microstrain, respectively after 1 million fatigue cycles. This strain values at bottom flange is only $18 \%$ of failure strain obtained from tension tests of coupon.

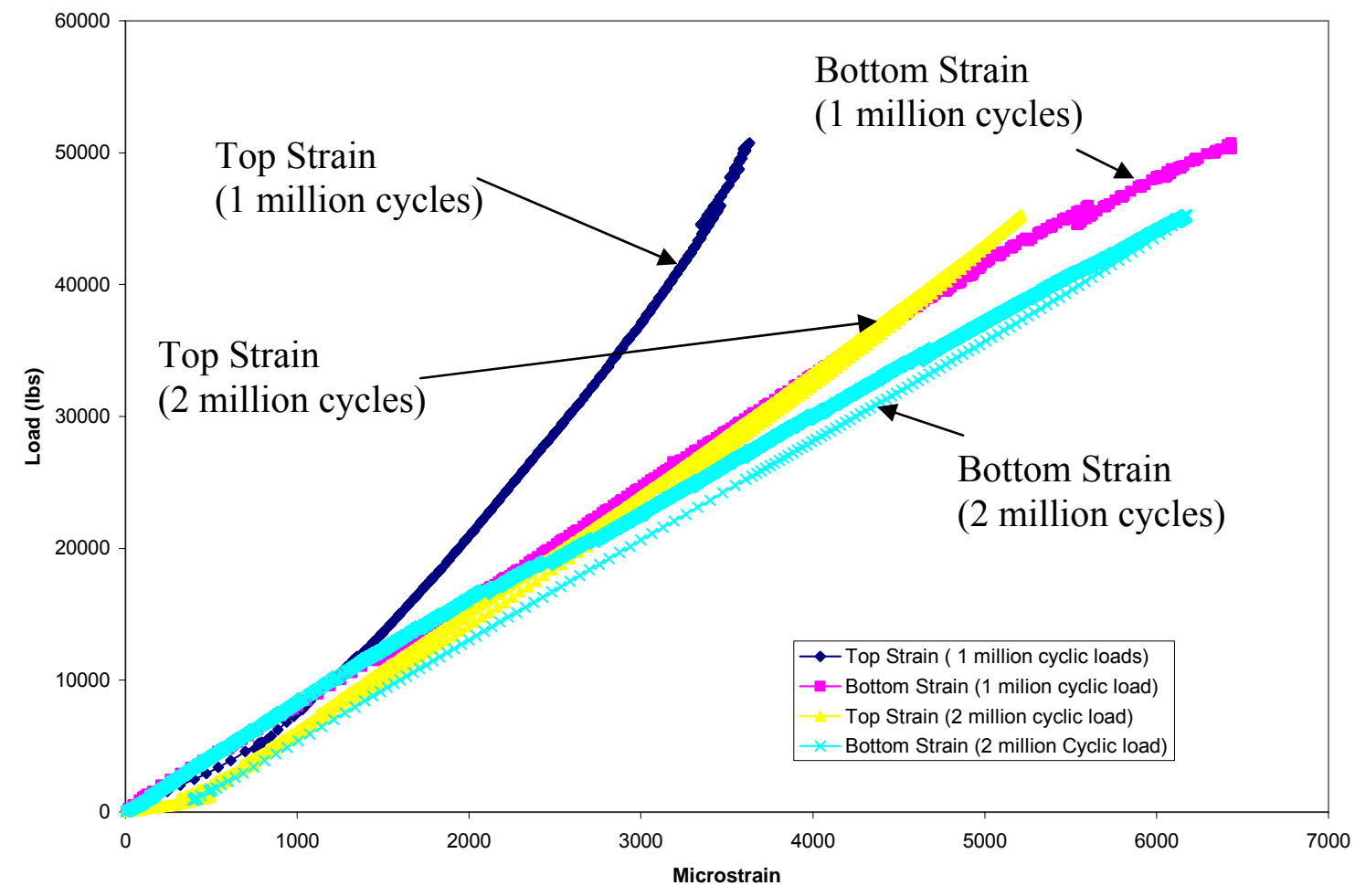

Figure 5.50 Strain at top and bottom flange of the panel after 1 and 2 million fatigue cycles 


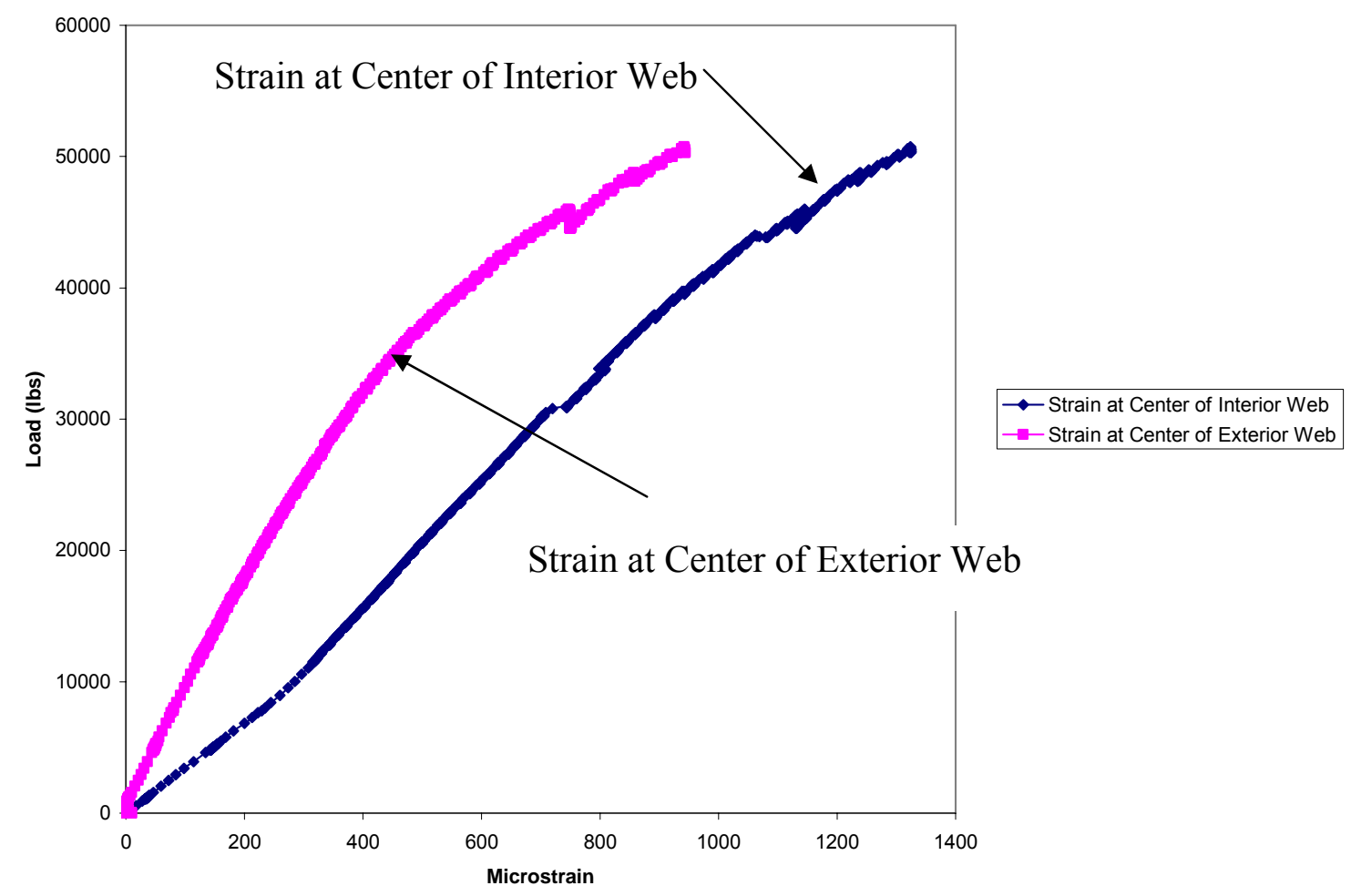

Figure 5.51 Strains at center of exterior and interior webs under static load (after 1 million fatigue cycles)

II. Strains at top flange were 2132 and 2892 Microstrain for 23 kips of static load, after panel underwent 1 million and 2 million fatigue cycles, respectively (Figure 5.50). The strains at bottom flange were 2815 and 3049 Microstrain under 23 kips static load, after panel underwent 1 million and 2 million fatigue cycles. The increase in strain value at top and bottom flange under 23 kips static load, was about 35\% and 9\% respectively. The increase in strain value is attributed to breaking of temporary wooden supports (used during manufacturing) after the panel underwent 2 million fatigue cycles. Reduction in panel stiffness was around $20 \%$ after 2 million fatigue cycles.

III. Strain in the interior web for a given load was about $45 \%$ higher than that of the exterior web. It indicates the degree of a lag in shear force transfer between webs of the panel away from the loading location. 


\subsubsection{Properties of Full Size Panels Manufactured and to be Installed in Field}

Total of sixteen panels with dimensions $13 \mathrm{ft}$ x $8 \mathrm{ft} 10$ inch were manufactured by Vacuum Assisted High Temperature Resin Infusion process. These panels will be installed in the field as a roadway pavement in Spring, 2009. One of these panels was tested under three point bending with a patch load of 20 inch $\times 10$ inch. Panels were tested in two directions as shown in Figures 5.52 and 5.53 below:

\section{Case I:}

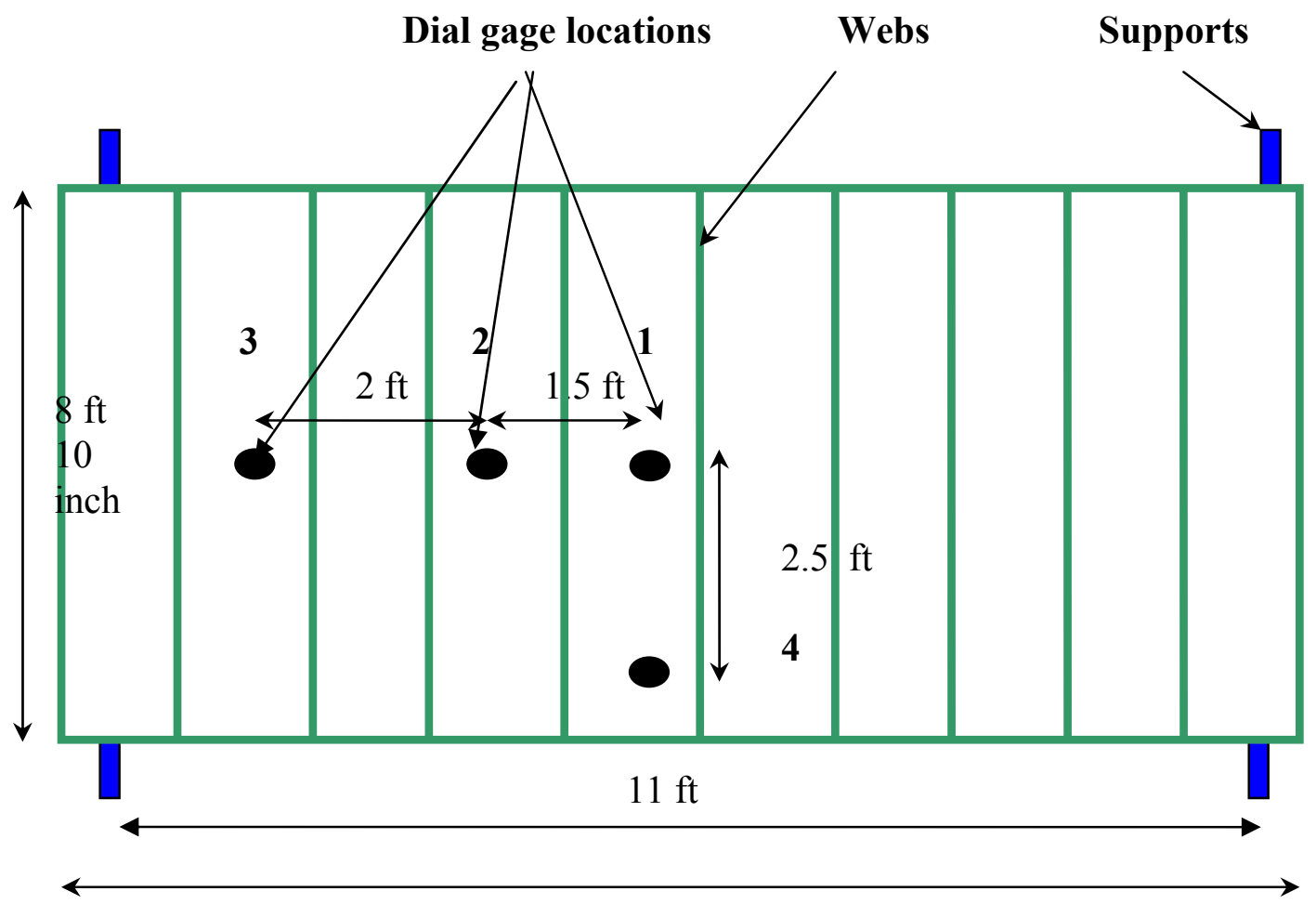

$13 \mathrm{ft}$

Figure 5.52 Schematic top view (not to the scale) of Case I loading condition of the panel with dial gage locations 


\section{Case II:}

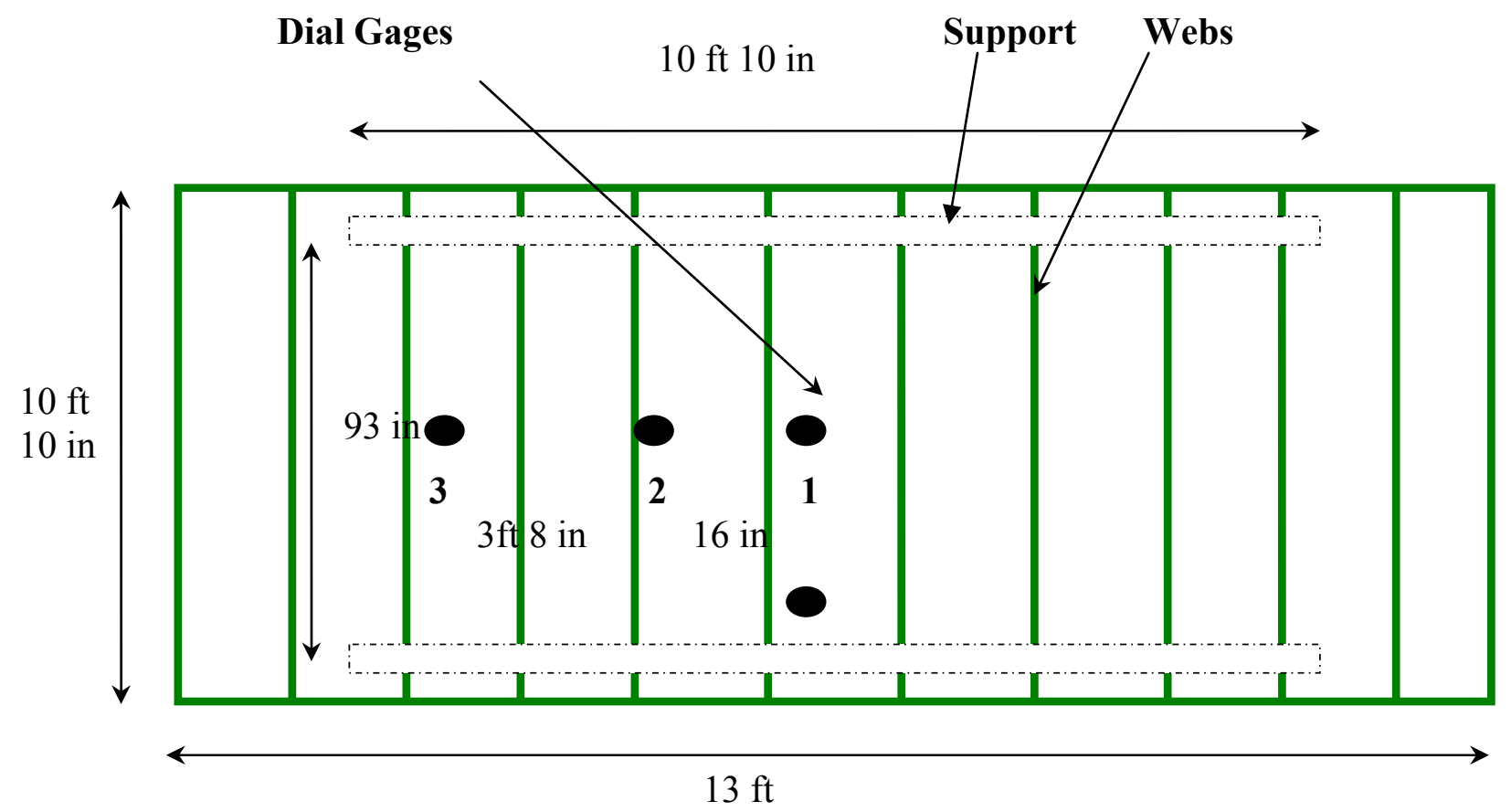

Figure 5.53 Schematic top view (not to the scale) of Case II loading condition of the panel with dial gage locations

Table 5.19 Results of the bending test conducted on the actual panel

\begin{tabular}{|c|c|c|c|c|c|c|}
\hline \multirow[b]{2}{*}{$\begin{array}{l}\text { Loading } \\
\text { Type }\end{array}$} & \multirow[b]{2}{*}{$\begin{array}{c}\text { Span } \\
\text { (in) }\end{array}$} & \multirow[b]{2}{*}{ I (in $)$} & \multicolumn{4}{|c|}{ E value (msi) } \\
\hline & & & $\begin{array}{c}\text { From } \\
\text { Stress- } \\
\text { Strain } \\
\text { Curve } \\
\text { (msi) }\end{array}$ & $\begin{array}{c}\text { From } \\
\text { Load- } \\
\text { Deflection } \\
\text { curve } \\
\text { (msi) }\end{array}$ & $\begin{array}{l}\text { From Load- } \\
\text { Deflection } \\
\text { curve after } \\
\text { deflection } \\
\text { under shear are } \\
\text { neglected } \\
\text { (msi) } \\
\end{array}$ & $\begin{array}{c}\text { Theoretically } \\
\text { Predicted } \\
\text { Value } \\
\text { (msi) }\end{array}$ \\
\hline Case I & 132 & 131.30 & 1.71 & 1.68 & ----- & ---- \\
\hline Case II & 93 & 167.42 & 1.54 & 1.44 & 2.77 & 2.93 \\
\hline
\end{tabular}




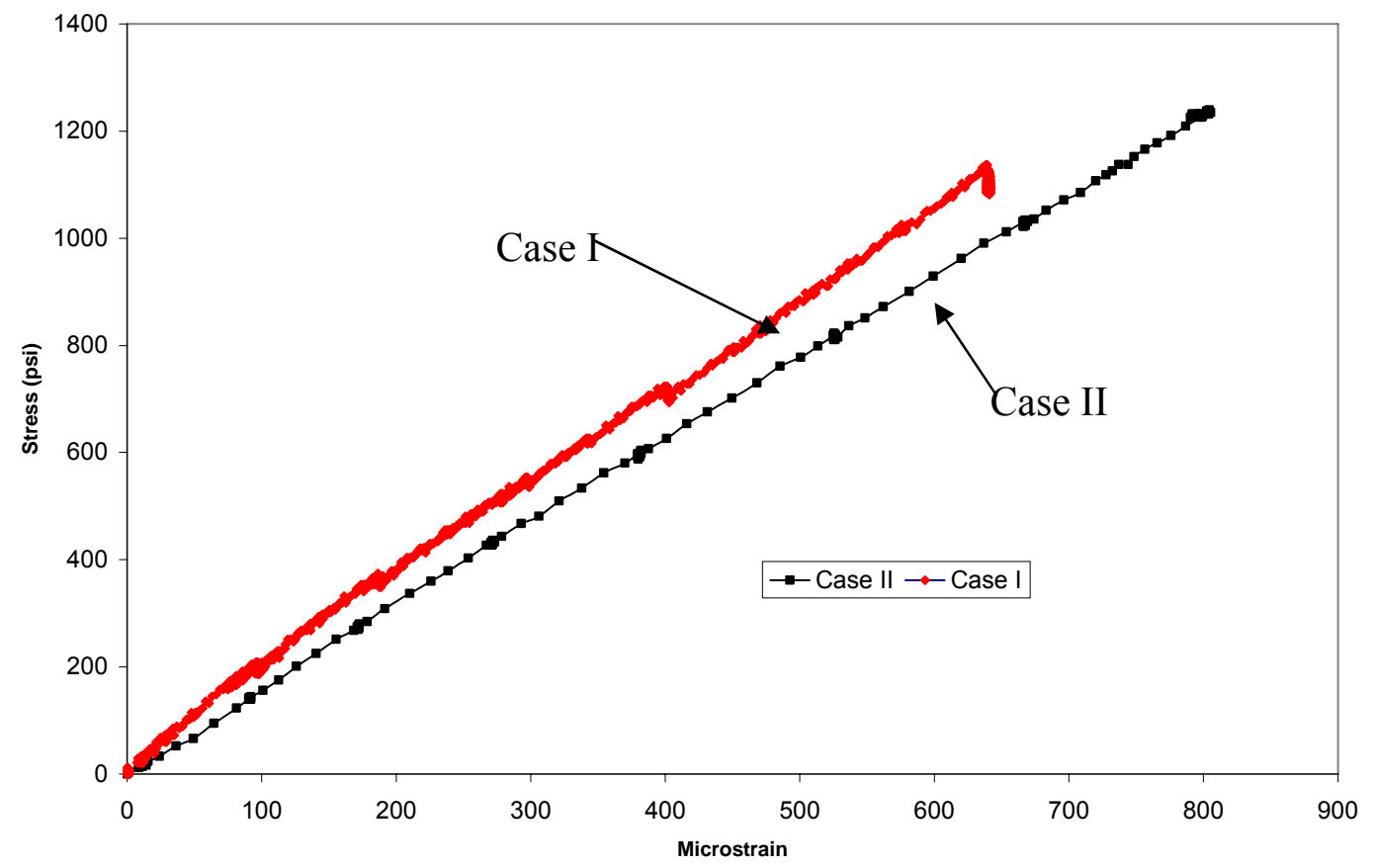

Figure 5.54 Stress-strain at the bottom of the panel along the span for Case I and Case II loading

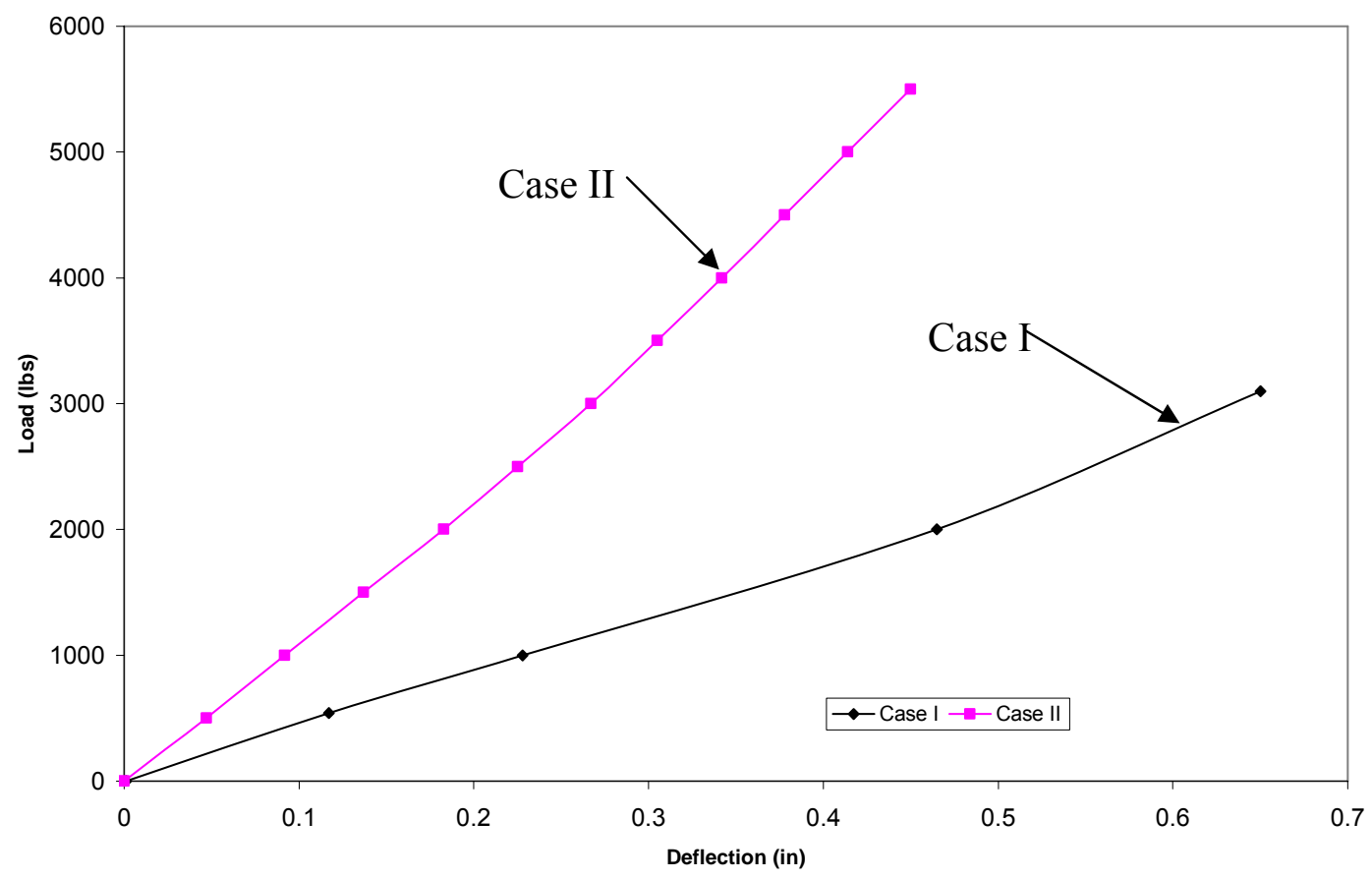

Figure 5.55 Load Vs deflection (at center) of the panel under Case I and Case II types loading 


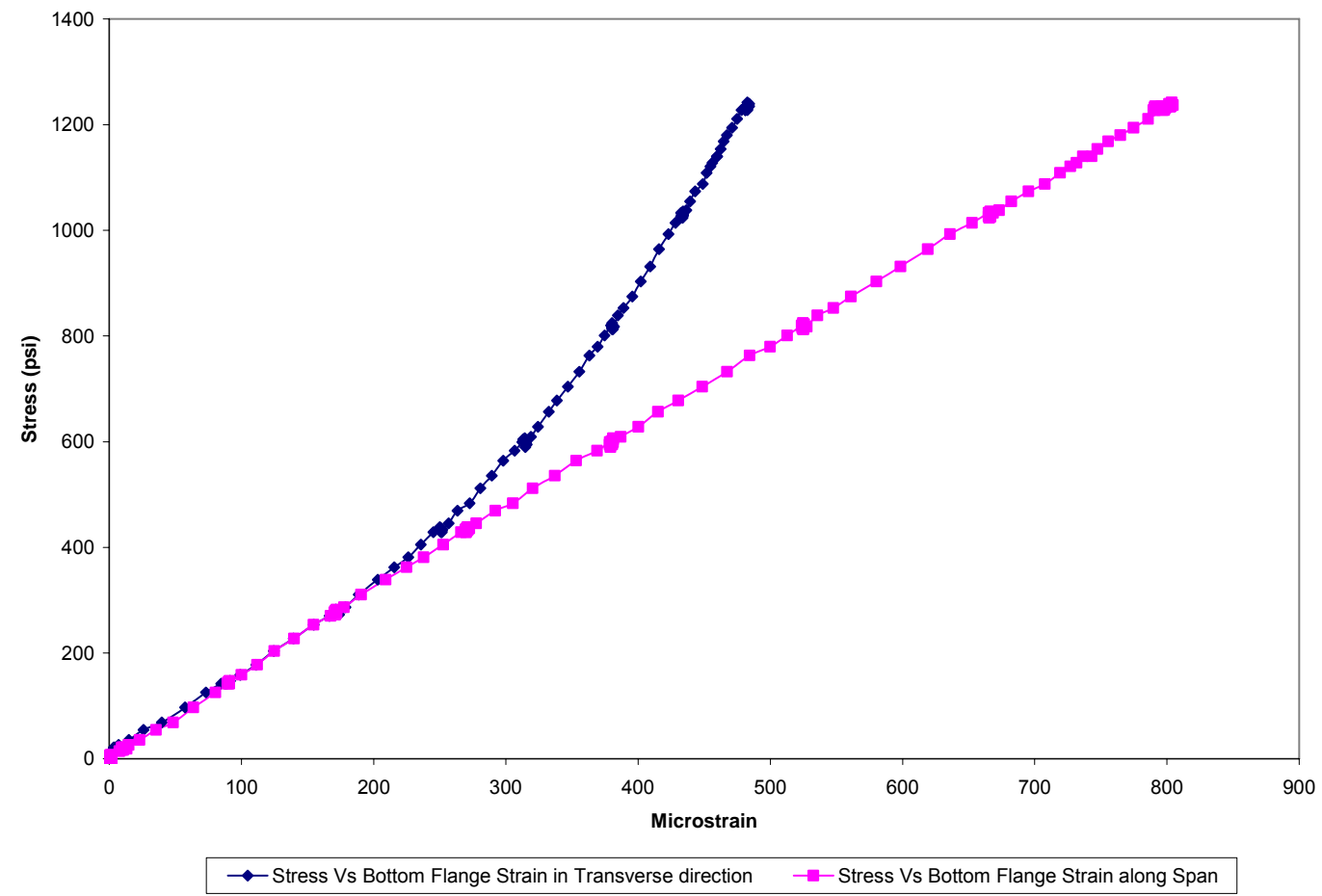

Figure 5.56 Stress Vs strain at the bottom flange in transverse and longitudinal directions under Case II Loading

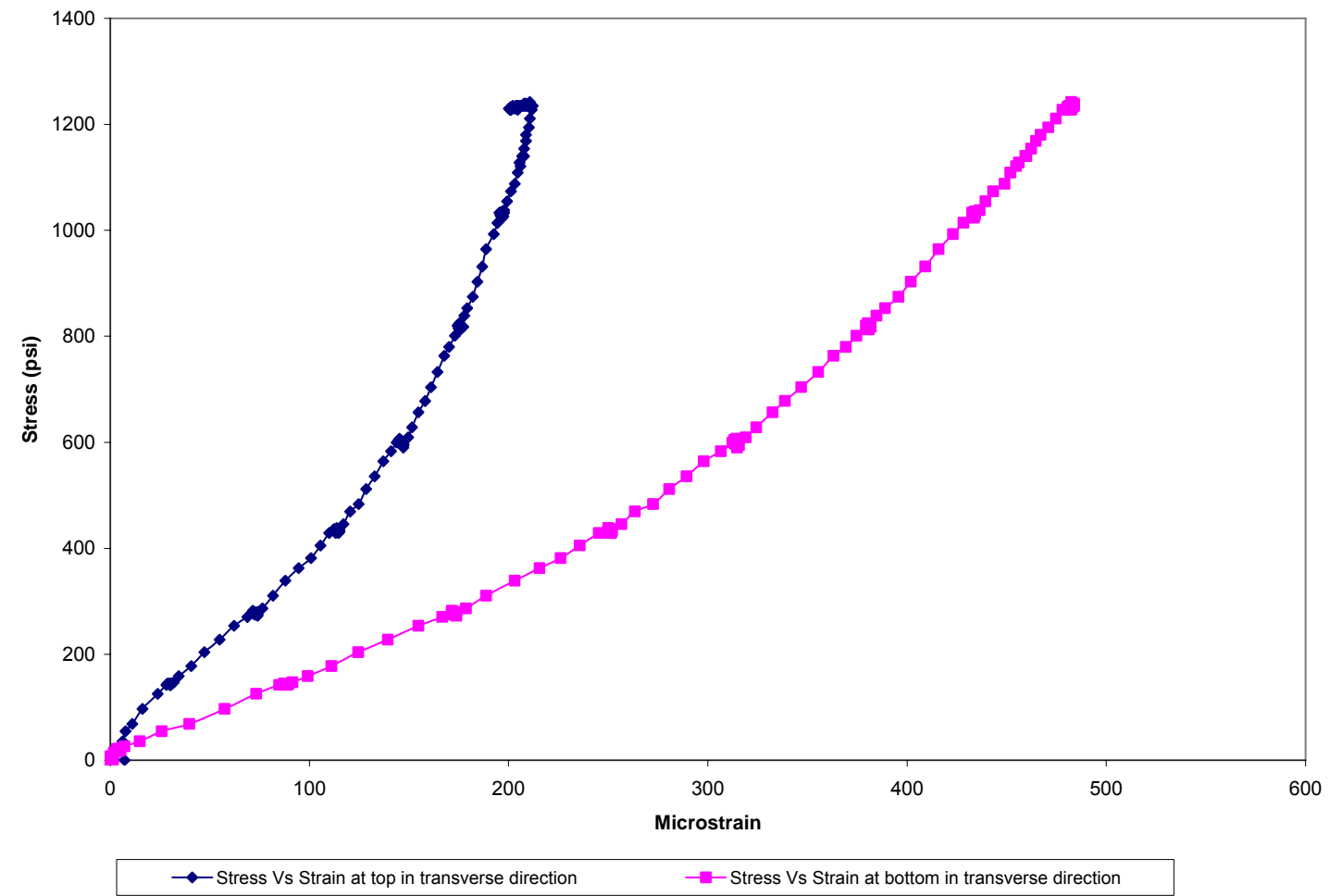

Figure 5.57 Stress Vs strain at top and bottom flanges in transverse directions under Case II loading 


\section{Discussion of test results:}

The following observations are made from the results:

I. The bending modulus of the full size panel when loaded as described in Case I was $1.70 \mathrm{msi}$. The panel stiffness when loaded as described in Case II was $1.50 \mathrm{msi}$ without the shear deflection correction factor. The bending stiffness of the panel (in case II) was $2.66 \mathrm{msi}$ after shear deflections were corrected in the computations from the measured deflection (Ref. Appendix D). Figures 5.54 to 5.57 show the stress-strain and load-deflection curves for the panel under Case I and Case II loading condition. The theoretically predicted stiffness of the panel was 2.93 (Ref. Appendix D). Panels would be field installed as continuously supported over the sub grade in all directions as pavement structure. From the test results of panels manufactured in Phase-I, Phase-II and during mass production stages, it is concluded that the panels are safe and efficient for field installation.

II. Stiffness of the panel was low compared to the theoretically predicted values due to the existence of weak fiber/fabric linking between two contiguous cells at some location as shown in Figure 5.58. It is recommended to improve quality of manufacturing.

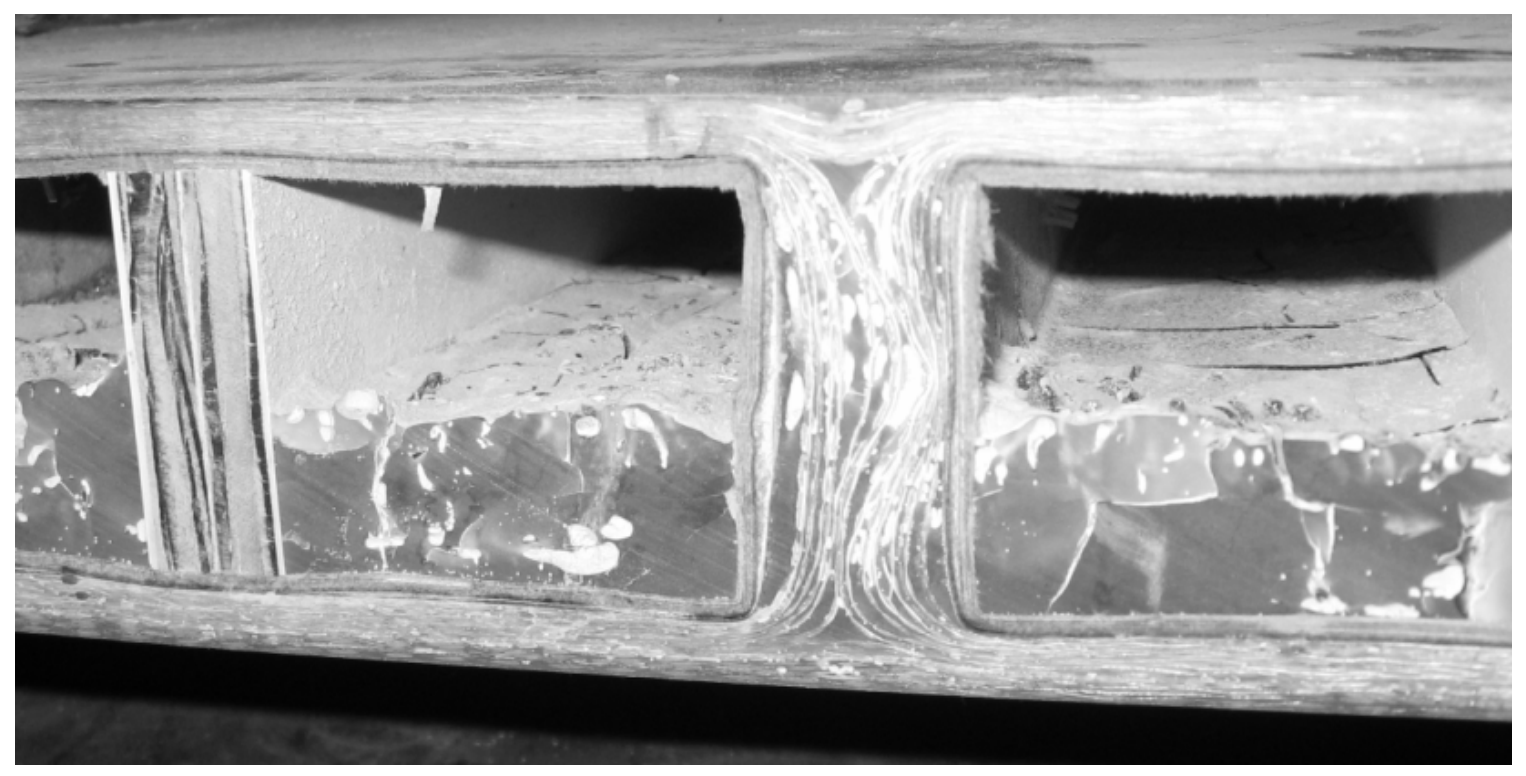

Figure 5.58 Resin accumulation and fiber/fabric at some webs 
III. The panel was loaded up to $3200 \mathrm{lbs}$ in Case I loading and Figure 5.54 shows almost linear variation of strains at bottom flange of the panel with respect to stress.

IV. The panel was loaded up to $6300 \mathrm{lbs}$ in Case II loading and Figure 5.56 shows the strain variation in longitudinal and transverse directions. The panel showed similar amount of strains in both directions up to a stress level of about $400 \mathrm{psi}$ and beyond that stress level, the panel started to carry more load (strain) along the longitudinal direction. 
Table 5.20 Summary of mechanical properties of panels at coupon and component levels

\begin{tabular}{|c|c|c|c|c|c|c|c|c|c|c|c|c|c|c|c|c|c|}
\hline \multirow{3}{*}{ Purpose } & \multicolumn{2}{|c|}{ FVF (\%) } & \multicolumn{6}{|c|}{ Coupon Bending } & \multicolumn{6}{|c|}{ Coupon Tension } & \multicolumn{2}{|c|}{$\begin{array}{c}\text { Coupon } \\
\text { Shear }\end{array}$} & \multirow{3}{*}{$\begin{array}{c}\text { Panel } \\
\text { Stiffness } \\
\text { (msi) }\end{array}$} \\
\hline & \multirow[t]{2}{*}{ Web } & \multirow[t]{2}{*}{ Flange } & \multicolumn{2}{|c|}{$\begin{array}{l}\text { Bending } \\
\text { Modulus } \\
\text { (msi) }\end{array}$} & \multicolumn{2}{|c|}{$\begin{array}{c}\text { Ultimate } \\
\text { Bending } \\
\text { Stress } \\
\text { (ksi) } \\
\end{array}$} & \multicolumn{2}{|c|}{$\begin{array}{c}\text { Failure } \\
\text { Microstrain }\end{array}$} & \multicolumn{2}{|c|}{$\begin{array}{l}\text { Tensile } \\
\text { Modulus } \\
\text { (msi) }\end{array}$} & \multicolumn{2}{|c|}{$\begin{array}{c}\text { Ultimate } \\
\text { Tensile Stress } \\
\text { (ksi) }\end{array}$} & \multicolumn{2}{|c|}{$\begin{array}{c}\text { Failure } \\
\text { Microstrain }\end{array}$} & \multirow[t]{2}{*}{$\begin{array}{l}\text { Web } \\
\text { (ksi) }\end{array}$} & \multirow[t]{2}{*}{$\begin{array}{c}\text { Flange } \\
\text { (ksi) }\end{array}$} & \\
\hline & & & Web & Flange & Web & Flange & Web & Flange & Web & Flange & Web & Flange & Web & Flange & & & \\
\hline Phase-I & 51 & 51 & 3.67 & 3.67 & 55 & 55 & 9953 & 8461 & 2.68 & 3.2 & 36 & 39 & 14626 & 9245 & 8 & 14 & 3.80 \\
\hline Phase-II & 53 & 48 & 2.30 & 2.66 & 46 & 46 & \multicolumn{2}{|c|}{$7732-15828$} & 2.26 & 2.58 & \multicolumn{2}{|l|}{28.5} & \multicolumn{2}{|c|}{$9198-15841$} & \multicolumn{2}{|l|}{5.65} & 3.20 \\
\hline $\begin{array}{l}\text { Test panel- } \\
\text { Mass } \\
\text { production }\end{array}$ & 33 & 55 & 1.5 & 2.75 & 42 & 24 & \multicolumn{2}{|l|}{13300} & 2.27 & 2.72 & 22 & 34.4 & \multicolumn{2}{|l|}{14513} & \multicolumn{2}{|l|}{5} & 3.43 \\
\hline $\begin{array}{l}\text { Full size } \\
\text { panel }\end{array}$ & - & - & - & - & - & - & - & - & - & - & - & - & - & - & - & - & 2.77 \\
\hline
\end{tabular}


Summary: In this chapter, we discussed the variation of bending properties of composites manufactured by HT-VARIM with different percentages of catalyst mixed with resin and curing temperatures. Results on the mechanical properties of panels at coupon and component levels, manufactured during different phases of this research are provided and discussed. Table 5.20 summarizes the mechanical properties of panels with different fiber architectures from different phases of manufacturing at coupon, component and prototype levels. In Chapter 6, we will summarize the findings of this research work including future recommendations that will be implemented, hopefullu as an extension of it. 


\section{CHAPTER 6 CONCLUSIONS AND RECOMMENDATIONS}

In this study, Glass fabric based modular composite panels were manufactured by HTVARIM process under (phase I \& II \& mass-production schemes). These composites were tested at the coupon, component, and prototype levels and parameters such as stresses, strains, stiffness, deflections, failure loads and failure modes were evaluated.

\subsection{Summary and Conclusions:}

The following conclusions were drawn from this study.

\subsubsection{Manufacturing Process}

- Bending properties of composites manufactured by HT-VARIM depend on curing temperature and amount of catalyst mixed with resin.

- Within room temperature to $200^{\circ} \mathrm{F}$ range and MEKP catalyst amount of $1.5-2.0 \%$ (percentage of resin by weight), composites with $150^{\circ} \mathrm{F}$ curing temperature and $1.5 \%$ MEKP, have less voids and provide better bending properties.

- Coupon specimens made with 7 layers of 24 oz/yd2 0/90/CSM and 42\% FVF (0.23 in thick) (cured at $150^{\circ} \mathrm{F}$ and $1.5 \%$ MEKP by weight) have ultimate bending stress of $\sim 40 \mathrm{ksi}$ and bending modulus of $\sim 2.2 \mathrm{msi}$.

- Air voids and dry fabric locations were found to be high in specimens cured at room temperature, $120^{\circ} \mathrm{F}$ and $200^{\circ} \mathrm{F}$.

- Coupon specimens cured at $200^{\circ} \mathrm{F}$ showed brittle failures under bending loads as compared to those cured at $150^{\circ} \mathrm{F}$.

- Additional research must be carried out in order to gain further information on the effects of curing temperature and amount of catalyst on material properties of composites.

\subsubsection{Phase-I FRP Panels Design, Manufacturing and Properties}

- Uniform FRP panel web thickness was achieved through the use of simplified external wooden frame.

- Resin applied from the top flange section of fabric wrapped cardboards showed adequate penetration into the webs of the panel. 
- Uni-axial fabrics without adequate stitching may be avoided for wrapping and top/bottom laminating of the panel due to handling difficulties. Instead, ones with sufficient ease of handling are recommended to be used.

- Air voids/dry fabric locations were not visible in specimens cut from webs and flanges of the panel indicating good fiber wet-out (Figure 5.24)

- Ends of tubes are recommended to be hermitically sealed to avoid flange sagging between two adjacent webs and to eliminate resin accumulation at the sagged locations.

\subsubsection{Phase-II FRP Design, Manufacturing and Properties}

- By stapling two adjacent cardboard tubes with wrapped fabrics at the webs, uniform web thickness and proper fiber/fabric placement can be maintained.

- Sagging of the flanges and resin accumulation were avoided by using temporary wooden supports.

- $9 \mathrm{ft}$ long cardboard tubes resulted in a final length of $8 \mathrm{ft} 10$ inch long cured panel. This information is required for deciding the length of cardboard tubes while manufacturing of composite panel of a particular dimension.

- Bottom and top flanges will have slightly different mechanical properties if top and bottom heating plates provide different heat levels.

- A $\sim 20 \%$ reduction of panel stiffness was noted after 2 million fatigue cycles $(3 \mathrm{~Hz}, 4$ kips-23 kips load range) under three point bending test.

- Deflections (deformations) of top flange cells (compression side) showed an increase of $\sim 13 \%$ after 1 million fatigue cycles.

- Panels underwent $\sim 19 \%$ and $\sim 12 \%$ of ultimate strains at bottom and top flanges when subjected to 23 kips of load on a gravel base after 2 million fatigue cycles.

\subsubsection{Properties of Test Panel Representing Mass Production}

- Ultimate bending stresses of top/bottom flanges and webs were $42 \mathrm{ksi}$ and $24 \mathrm{ksi}$ respectively. Bending moduli of flanges and webs were $2.75 \mathrm{msi}$ and $1.5 \mathrm{msi}$ respectively. Ultimate failure strain of flange and web specimens was 13300 Microstrain.

- Ultimate tensile stresses of top/bottom flanges and webs were $34 \mathrm{ksi}$ and $22 \mathrm{ksi}$, respectively. Tensile moduli of flanges and webs were $2.72 \mathrm{msi}$ and $2.27 \mathrm{msi}$, 
respectively. Ultimate failure strain of flange and web specimens was 14500 Microstrain

- Bottom and top flanges with same fiber/fabric configuration showed similar mechanical properties.

- $\sim 20 \%$ reduction in panel stiffness after 2 million fatigue cycles $(3 \mathrm{~Hz}, 4$ kips-23 kips load span) was noted when tested under three point bending.

- Strains in bottom and top flanges of the panel were $\sim 19 \%$ and $\sim 13 \%$ of their ultimate failure strain when subjected to $23 \mathrm{kips}$ load on a gravel base after 2 million fatigue cycles.

- Under loads ranging from 23-30 kips, panel showed tendency to lift-up at a distance greater than $\sim 3.5 \mathrm{ft}$ from the center of wheel load, when tested on a gravel base. It is recommended to anchor these panels at a spacing of 3-4 $\mathrm{ft} \mathrm{C} / \mathrm{C}$.

- Even if there is a loss of subbase support for a span of $2 \mathrm{ft}$ under the filed installed panel in the field (Figure 5.47), the panel will be subjected to only $18 \%$ of the ultimate failure strain (after 1 million fatigue cycles).

- The difference in strain values between interior and exterior webs under a patch load was $45 \%$.

\subsubsection{Full Size Panel Design, Manufacturing and Properties}

- Sixteen prototype FRP panels measuring $13 \mathrm{ft}$ x $8 \mathrm{ft} 10$ inch panels were successfully manufactured for field installation as roadway pavements and one of these was tested under static loading in both longitudinal and transverse directions.

- Panels will be field installed near Morgantown High School in cooperation with WVDOH in Spring 2009, in a direction such that the traffic flow is perpendicular to the direction of webs.

\subsection{Future Recommendations:}

- The effect of curing temperature and MEKP percentage added to resin, on air entrapment and void generation must be further studied by evaluating more numbers of specimens cut from different locations of plates manufactured by HT-VARIM.

- The ends of the cardboard tubes should be properly closed to avoid leakage and accumulation of large amount of resin at bottom flange. 
- The ends of the cardboard tubes should be hermitically sealed to minimize and/or eliminate sagging of flanges and use of temporary wooden supports could be avoided.

- Quality of manufacturing can be improved by controlling fiber/fabric placement and resin application.

- Web fabrics between two adjacent cells should be stitched together in order to get proper shear transfer across webs.

- Efficient web shear force transfer could be achieved by utilizing 3-D stitching technique discussed in Appendix C by Manab Medhi, Hota GangaRao, and Vimala, Shekar, Provisional patent: 60/918398. 


\section{REFERENCES}

1. Bambal A. S., 2007, Mechanical evaluation and FE modeling of composite sandwich panels, M.S. Thesis, CEMR, WVU.

2. Barbero E.J., 1998, Introduction to composite material design, Taylor \& Francis, Philadelphia.

3. Desai A.V., 2007, Finite element analysis of composite bridge deck Joints, M.S. Thesis, WVU.

4. GangaRao H.V.S., Shekar V., 1999, Development of glass fiber reinforced polymer composite bridge deck, SAMPE Journal, Vol. 35, No. 4.

5. Cain Jason J., Nathan L. P., John J. L.O., Scott W. C., 2006, Post-curing effects on marine VARTM FRP composite materials properties for test and implementation, Journal of engineering materials and technology, Vol. 128, pp. 34-40.

6. Karbhari V.M. and Seible F., 1997, International symposium on non-metallic reinforcement for concrete structures, sapparo, Japan, pp 191-198.

7. Luke Sam, Canning Lee, Collins Simon, Knudsen Eric, Brown Peter, Taljsten Bjorn, Olofsson Ingvar, 2002, Advanced composite bridge decking system-project ASSET, Structural engineering international, Vol. 12, No. 2, pp. 76-79.

8. Mallick P.K., 1997, Composites engineering handbook, Marcel Dekker, Inc.

9. Nagaraj V., 1994, Static and fatigue response of pultruded FRP beams without and with splice connections, M.S. Thesis, CEMR, WVU.

10. Juska Thomas D., Puckett Paul M., 1997, Matrix Resins and Fiber/Matrix Adhesion, Composites engineering handbook, Marcel Dekker, Inc.

11. www.netcomposites.com

12. Shehata Emily, Mufti Aftab, 2005, The "Manitoba" GFRP bridge deck system, FRP international, Vol. 2, issue 1, pp. 2-4.

13. Vadlamani D., 2007, Strain energy density based failure criterion for GFRP coupons under tension and bending, M.S. Thesis, WVU.

14. Vimala S, 2007, Effect of fiber architecture on properties of pultruded composites, M.S. Thesis, CEMR, WVU.

15. Williams Brea, Shehata Emily, Rizkalla Samo. H., 2003, Filament-wound Glass Fiber Reinforced Polymer bridge deck modules, Journal of composite for construction, Vol. 7, No. 3, pp. 266-273. 
16. Wu. F. H April, 2005, Composite in Civil Applications, Advanced Technology Program, NIST. (www.atp.nist.gov).

17. Ziaee S., Palmese G.R., 1999, Effects of temperature on cure kinetics and mechanical properties of vinyl ester resins, Journal of Polymer Science: Part B, Vol. 37, pp. 725744. 


\section{APPENDIX A INSTALLATION OF PAVEMENTS}

\section{A.1 Introduction}

In this appendix, layout and connection procedure for field installation of FRP pavement panels designed and manufactured by HT-VARIM, are discussed. Figure A.1 shows the panel layout and connection details. An FRP I-beam section will be used in order to connect panels in directions parallel and longitudinal to the traffic flow. A total of sixteen panels will be field installed in cooperation with WVDOH. In section A.3, the ground anchor system to be used for anchoring the panels to the supporting sub base (ground) is discussed. Figure A.4 shows the experimental set up used to test the anchors in the field. Also, grouting of holes made for anchor installation is discussed in section A.3.3. Some of these details may be further modified in consultation with WVDOH as per field requirements. 
Figure A.1 Panel layout and connections

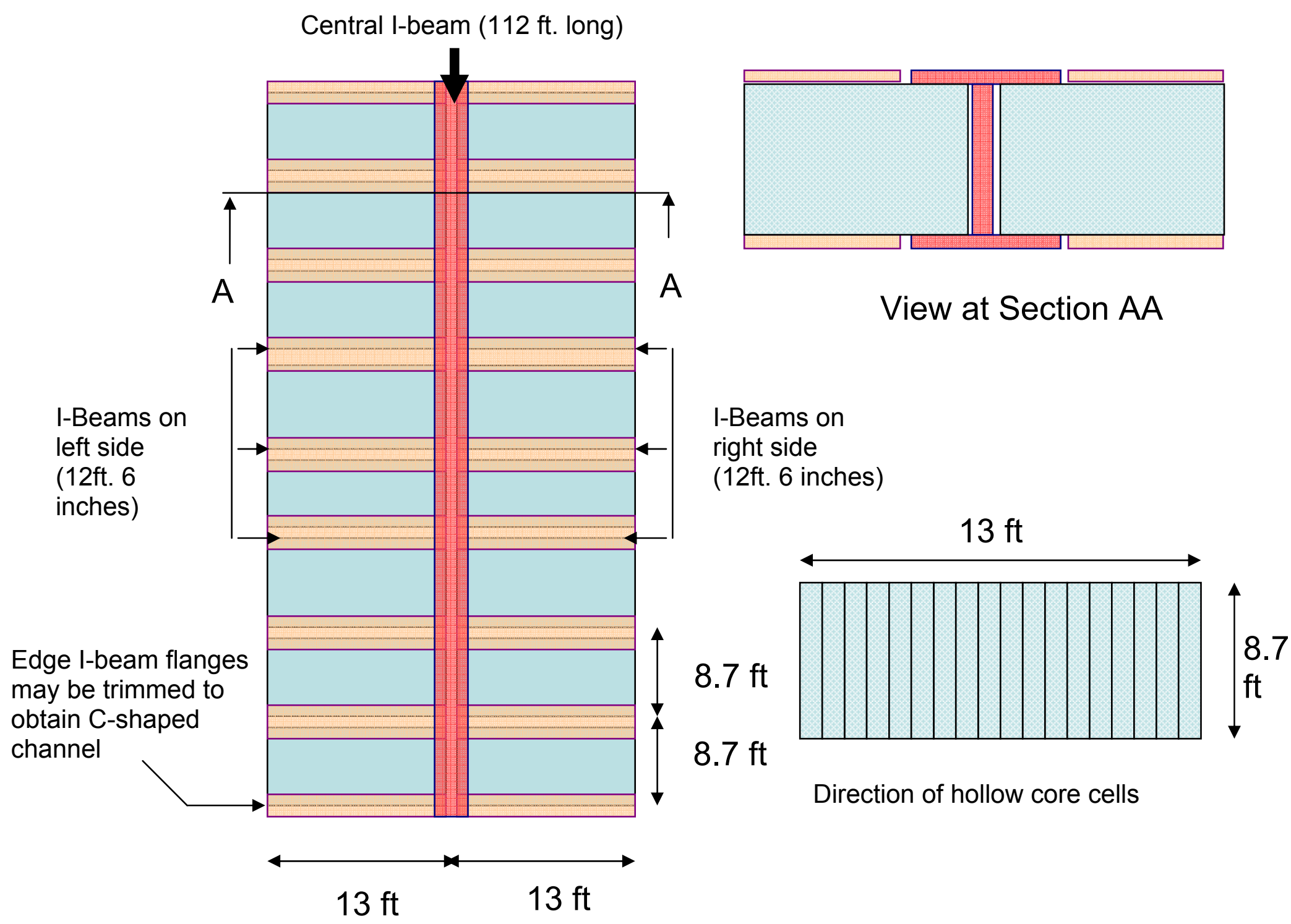




\section{A.3 Dimensions of Panels}

Length of each panel: 8.67 feet (104”)

c/c length of panels: $104 "+((2 *(0.25 " / 2 "$ I-beam web thickness +0.25 " clearance $))$

$=104.75 "=8.73 \mathrm{ft}$.

Total number of $26 \mathrm{ft}$. (13 ft x 2) wide (in two lanes) panels: 13

Length of the pavement: $13 * 8.73^{\prime}=112 \mathrm{ft}$.

\section{A.4 Ground Anchors}

In this section, we discussed about ground anchor layouts and different types of anchors we tested.

\section{A.4.1 Ground Anchor Layout}

Please refer to Figure A.2.

Number of anchors required by each $13 \mathrm{ft}$ wide panel: 12

Total number of anchors required by $13 \times 2$ panels $=26 \times 12=312$

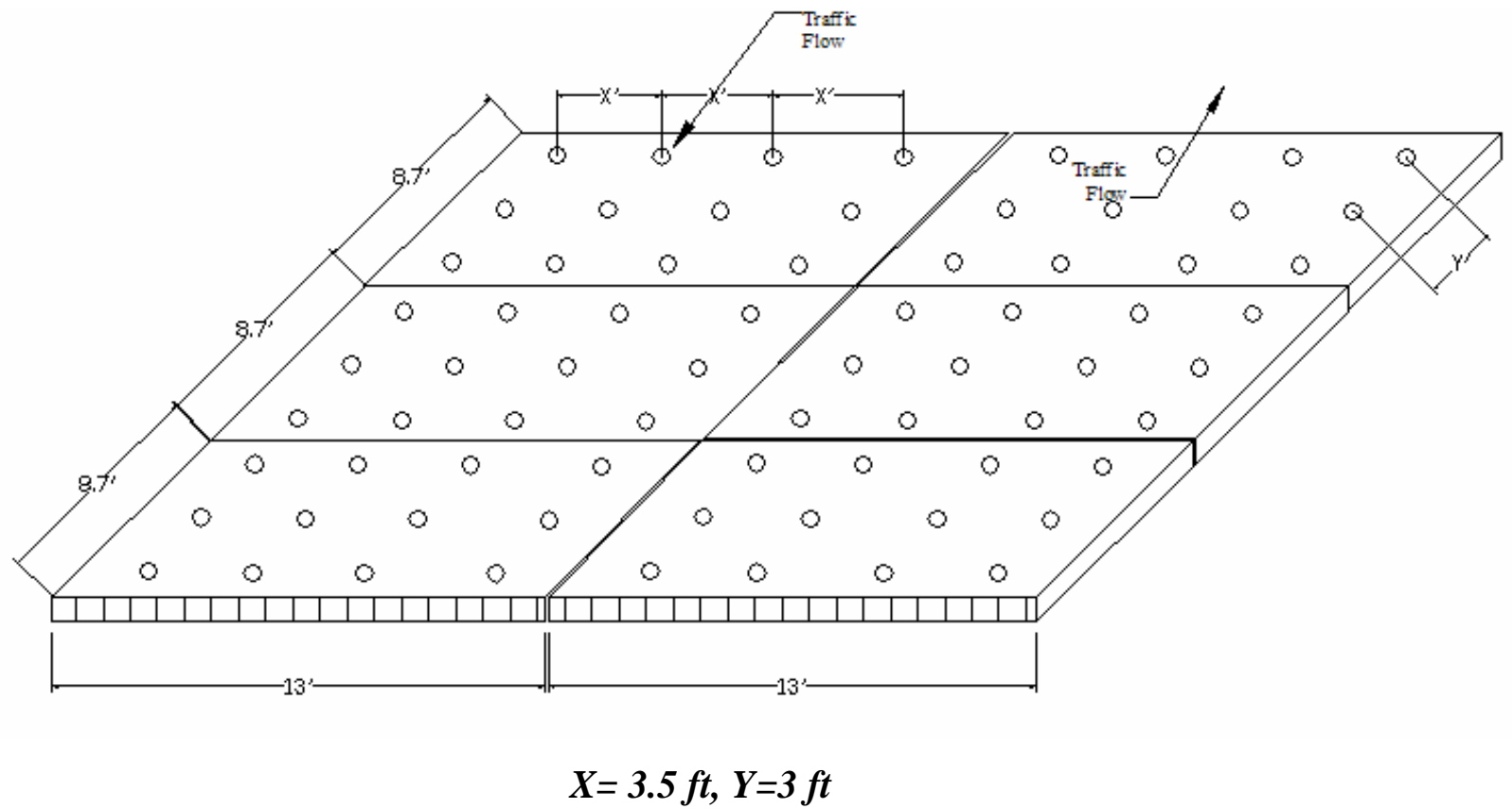

Figure A.2 Pavement panels with anchor holes.

(It is a conceptual diagram only, panels shown in the Figure does not refer to actual number of panels required) 


\section{A.4.2 Ground Anchor Types}

We field tested anchor systems (Figure A.4) as shown in Figure A.3. The anchor system configured for field installation is shown in Figure A.4 (supplied by "The Down Engineering").

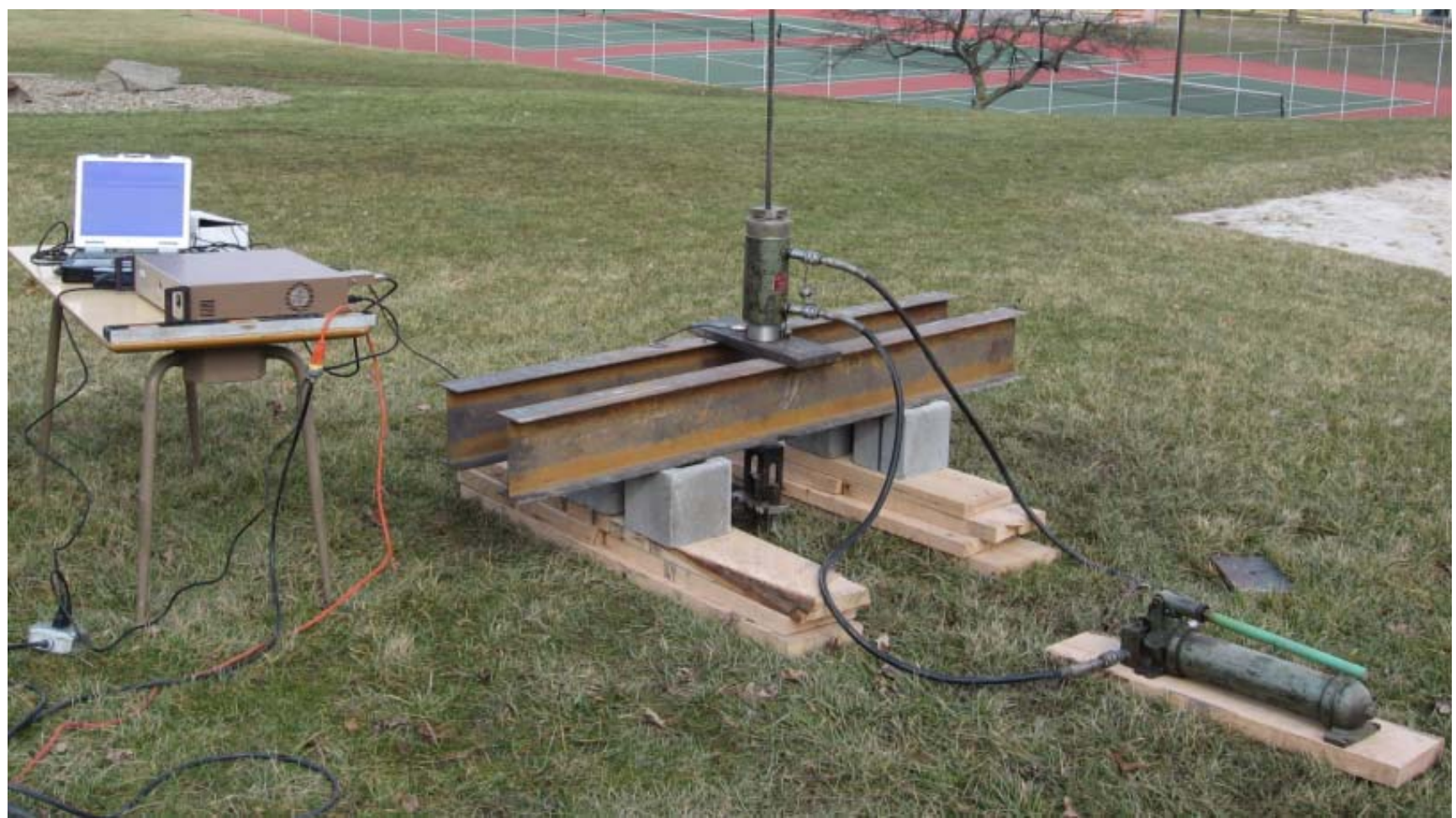

Figure A.3 Testing set up for the ground anchors

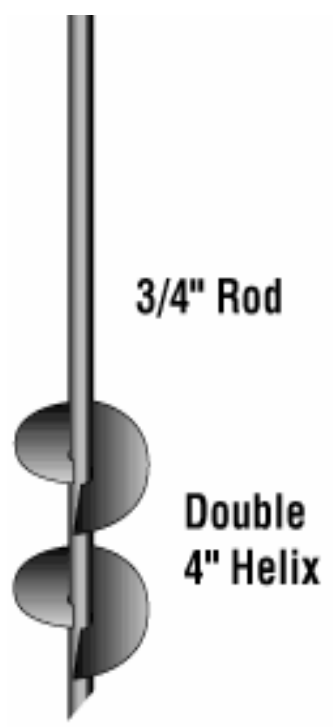

Figure A.4 Anchor system 
Table A.1 Specification supplied by "The ground anchor"

\begin{tabular}{|c|c|c|c|c|}
\hline $\begin{array}{c}\text { Model } \\
\text { Number }\end{array}$ & Anchor Description & $\begin{array}{c}\text { Soil Type } \\
\text { as Tested }\end{array}$ & $\begin{array}{c}\text { Tested Soil } \\
\text { Capacity } \\
\text { (ft.lb.) }\end{array}$ & $\begin{array}{c}\text { Anchor Capacity } \\
\text { (lbs) }\end{array}$ \\
\hline 59040 & $3 / 4^{\prime \prime} \times 60^{\prime \prime}$ w/ Single 8" Helix & 4 & 275 & 3400 \\
59045 & $3 / 4^{\prime \prime} \times 48^{\prime \prime}$ w/ Single 6" Helix & 4 & 325 & 5000 \\
59050 & $1 / 2^{\prime \prime} \times 15^{\prime \prime}$ w/ Single 4" Helix & 2 & 500 & 800 \\
59052 & $3 / 4^{\prime \prime} \times 42^{\prime \prime}$ w/ Single 4" Helix & 3 & 375 & 4300 \\
59055 & $1 / 2^{\prime \prime} \times 30^{\prime \prime}$ w/ Single 4" Helix & 2 & 500 & 2400 \\
$59055 \mathrm{THG}$ & $1 / 2^{\prime \prime} \times 30^{\prime \prime}$ w/ Double 4" Helix & 2 & 500 & 2250 \\
59060 & $5 / 8^{\prime \prime} \times 40^{\prime \prime}$ w/ Single 6" Helix & 3 & 375 & 4500 \\
59065 & $5 / 8^{\prime \prime} \times 48^{\prime \prime}$ w/ Single 6" Helix & 4 & 300 & 3000 \\
\hline
\end{tabular}

\section{A.4.3 Grouting of the Holes}

Grouting of the holes made for anchor installation will be done as shown in Figure A.5.

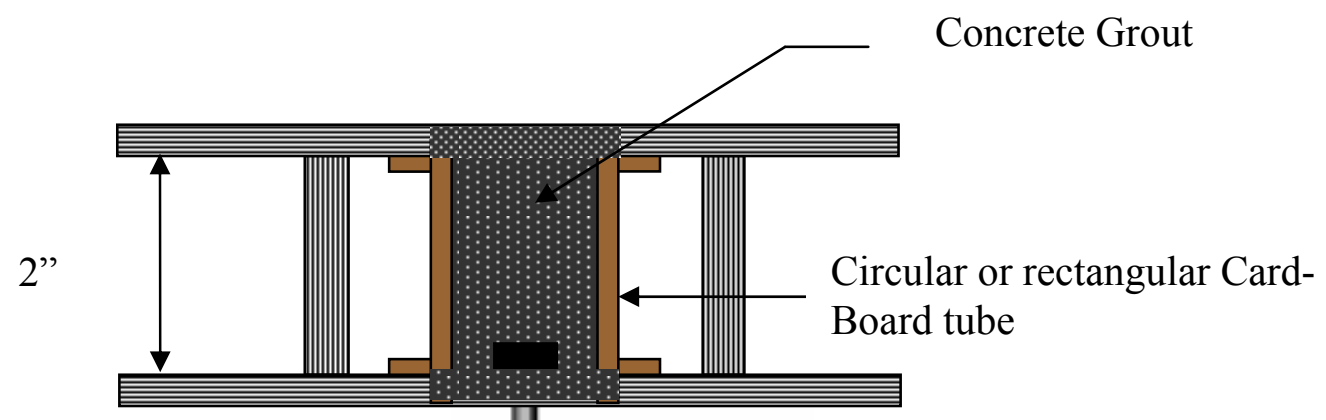

\section{3/4" Rod}

Figure A.5 Grouting of the anchor hole 
As shown in Figure A.6, circular rectangular car-boards or flexible tubes that can be used for grouting of the holes.

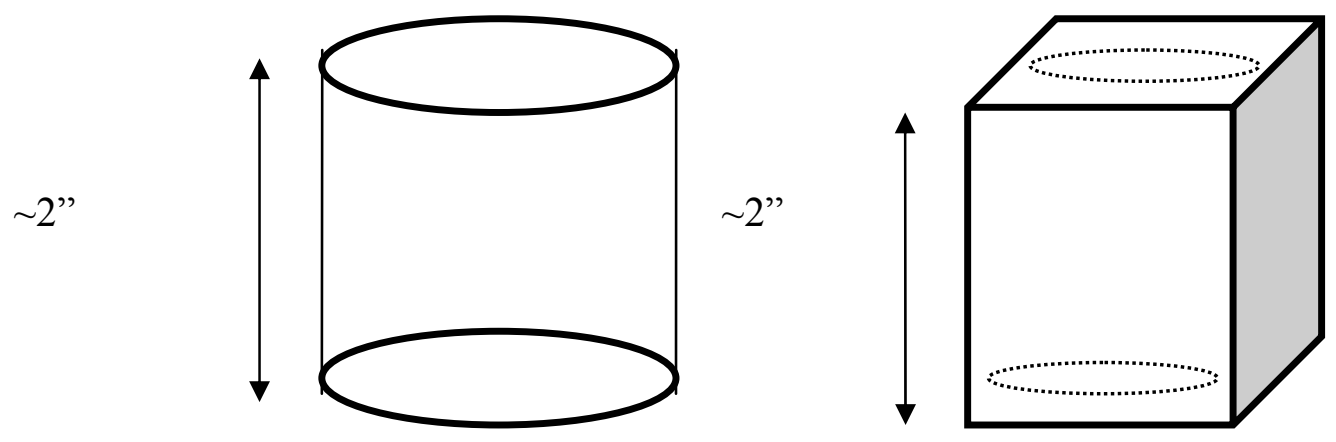

Figure A.6 Circular or rectangular card-boards (left) or flexible tubes (right) 


\section{APPENDIX B LIGHTWEIGHT HONEYCOMB PANEL}

During this research work, we have also devolved lightweight honeycomb panel with Glass Fabric, Vinyl Ester resin and polyurethane as a core material. Table B.1 gives the details of three types of specimens we prepared by HT-VARIM.

Table B.1 Details of thee types of specimens prepared

\begin{tabular}{|c|l|l|l|}
\hline Sample Type & $\begin{array}{r}\text { Fabric wrapped } \\
\text { around the core }\end{array}$ & $\begin{array}{l}\text { Fabric at the top or } \\
\text { bottom face carpet }\end{array}$ & \multicolumn{1}{|l|}{ Weight $\left(\mathbf{l b} / \mathbf{f t}^{2}\right)$} \\
\hline I & No fabric Wrapped & $\begin{array}{l}3 \text { layers of } 12 \mathrm{oz} / \mathrm{yd}^{2} \\
0 / 90\end{array}$ & $1.43 \mathrm{lb} / \mathrm{ft}^{2}$ \\
\hline II & $\begin{array}{l}3 \text { layers of } 21.75 \\
\text { oz/yd } / 4+45 /-45\end{array}$ & $\begin{array}{l}2 \text { layers of } 12 \mathrm{oz} / \mathrm{yd}^{2} \\
0 / 90\end{array}$ & $2.00 \mathrm{lb} / \mathrm{ft}^{2}$ \\
\hline III & $\begin{array}{l}5 \text { layers of } 21.75 \\
\text { oz/yd } 0 /+45 /-45\end{array}$ & $\begin{array}{l}4 \text { layers of } 12 \mathrm{oz} / \mathrm{yd}^{2} \\
0 / 90\end{array}$ & $4.7 \mathrm{lb} / \mathrm{ft}^{2}$ \\
\hline
\end{tabular}

Figure B.1 shows the polyurethane honeycomb core which was cut into a dimension of 25 inch $\mathrm{x} 4$ inch, and wrapped around with tri-axial fabrics. Each fabric wrapped core was kept

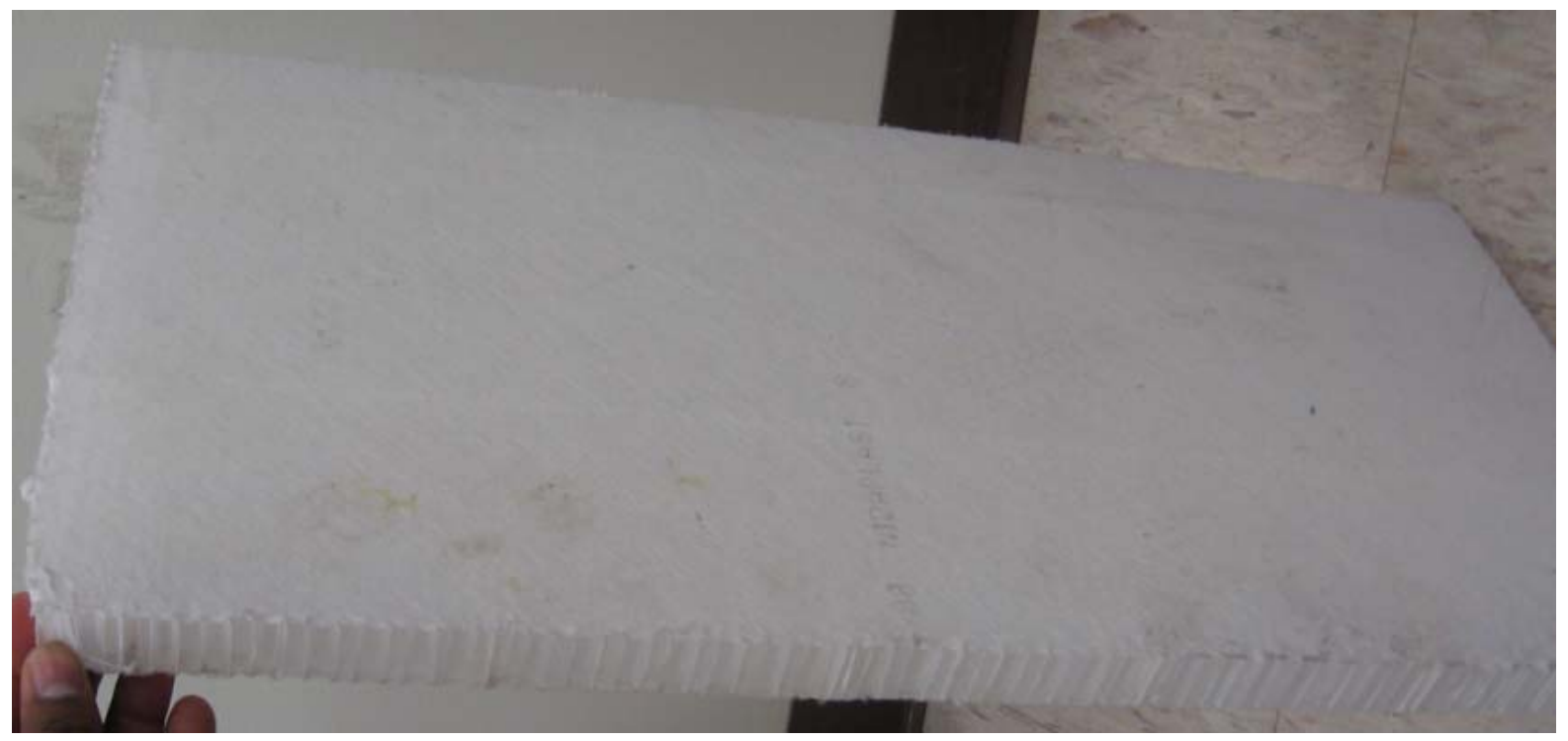

Figure B.1 Polyurethane honeycomb Core 
adjacent to each other and bi axial fabrics were placed at the top and bottom prior to resin infusion. Figure B.2 shows the bending test on type I specimen.

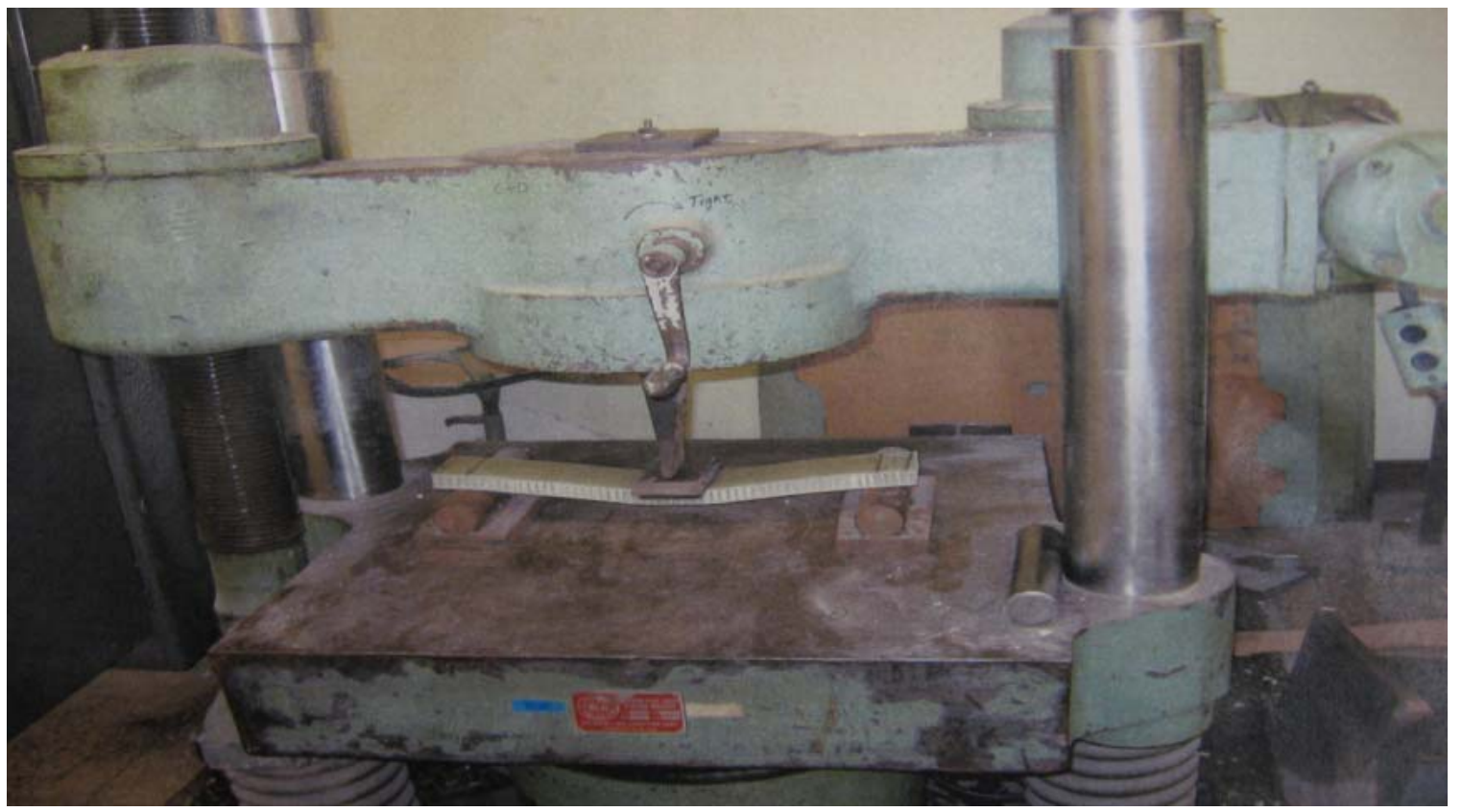

Figure B.2 Bending test of type I honeycomb panel

Table B.2 Bending test results of type I honeycomb panel

\begin{tabular}{|l|l|l|l|l|l|l|}
\hline $\begin{array}{l}\text { Effective } \\
\text { Span } \\
\text { C-C } \\
\text { (inch) }\end{array}$ & $\begin{array}{l}\text { Width } \\
\text { (inch) }\end{array}$ & $\begin{array}{l}\text { Face } \\
\text { Thickness } \\
\text { (inch) }\end{array}$ & $\begin{array}{l}\text { Total } \\
\text { Depth } \\
\text { (inch) }\end{array}$ & $\begin{array}{l}\text { Moment } \\
\text { of Inertia } \\
\left.\text { (in }^{4}\right)\end{array}$ & $\begin{array}{l}\text { Ultimate } \\
\text { Load } \\
\text { (lbs) }\end{array}$ & $\begin{array}{l}\text { Bending } \\
\text { Stress } \\
\text { (psi) }\end{array}$ \\
\hline 17.25 & 3 & 0.09 & 0.93 & 0.1168 & 275 & 4722 \\
\hline
\end{tabular}

Sample Calculation:

Moment of inertia $=2 \times\left(3 \times 0.09^{3} / 12+3 \times 0.09 \times(0.93 / 2)^{2}\right) \sim=0.117 \mathrm{in}^{4}$

Ultimate bending stress $=(275 \times 17.25 \times 0.25) \times(0.93 / 2) / 0.1168 \sim=4722 \mathrm{psi}$

Table B.2 shows the test results of bending test done on a 3 inch wide sample cut from type I panel.

Similar tests were done on type II and III honeycomb panels as shown in Figures B.3 and B.4 respectively. 


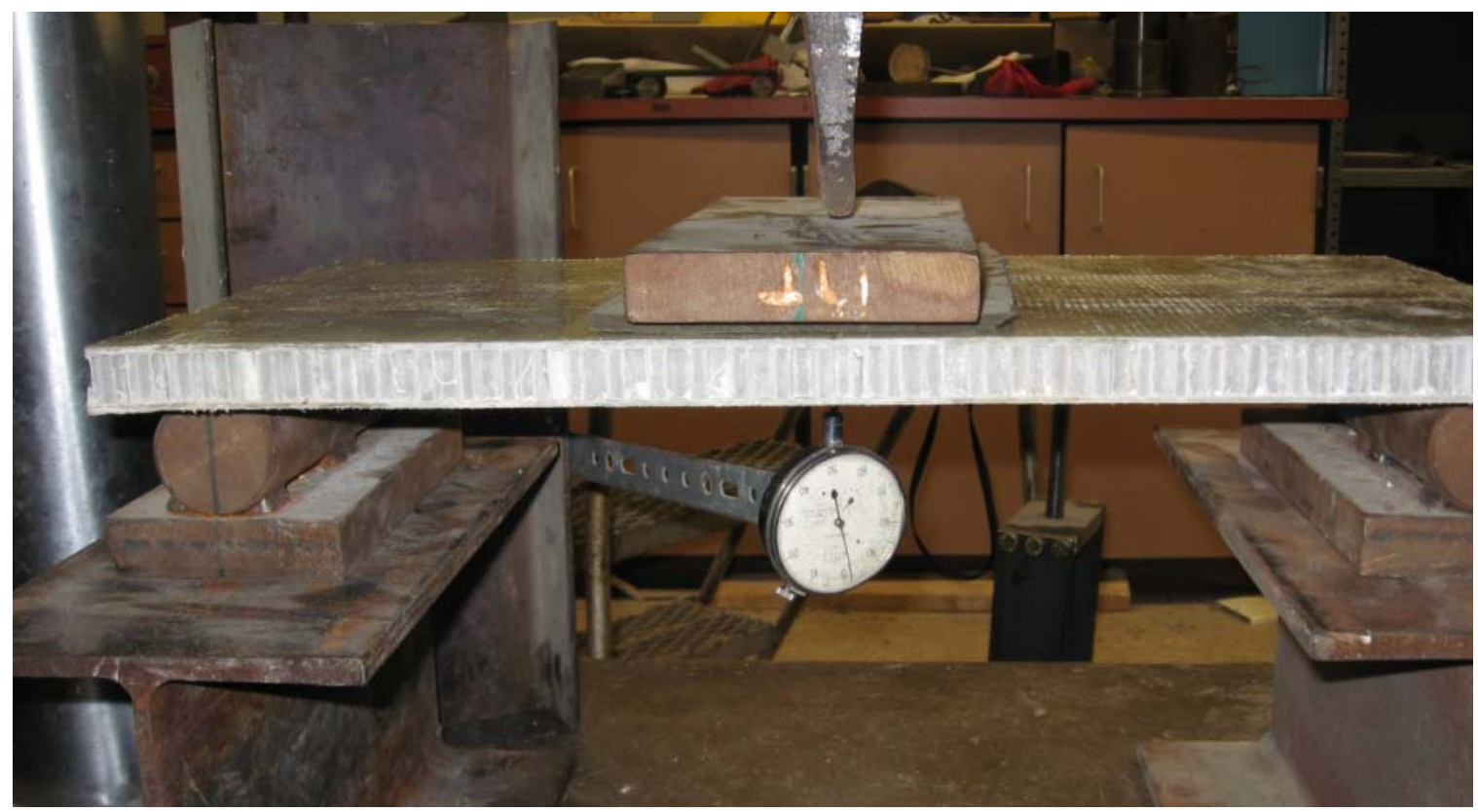

Figure B.3 Bending test of type II panel

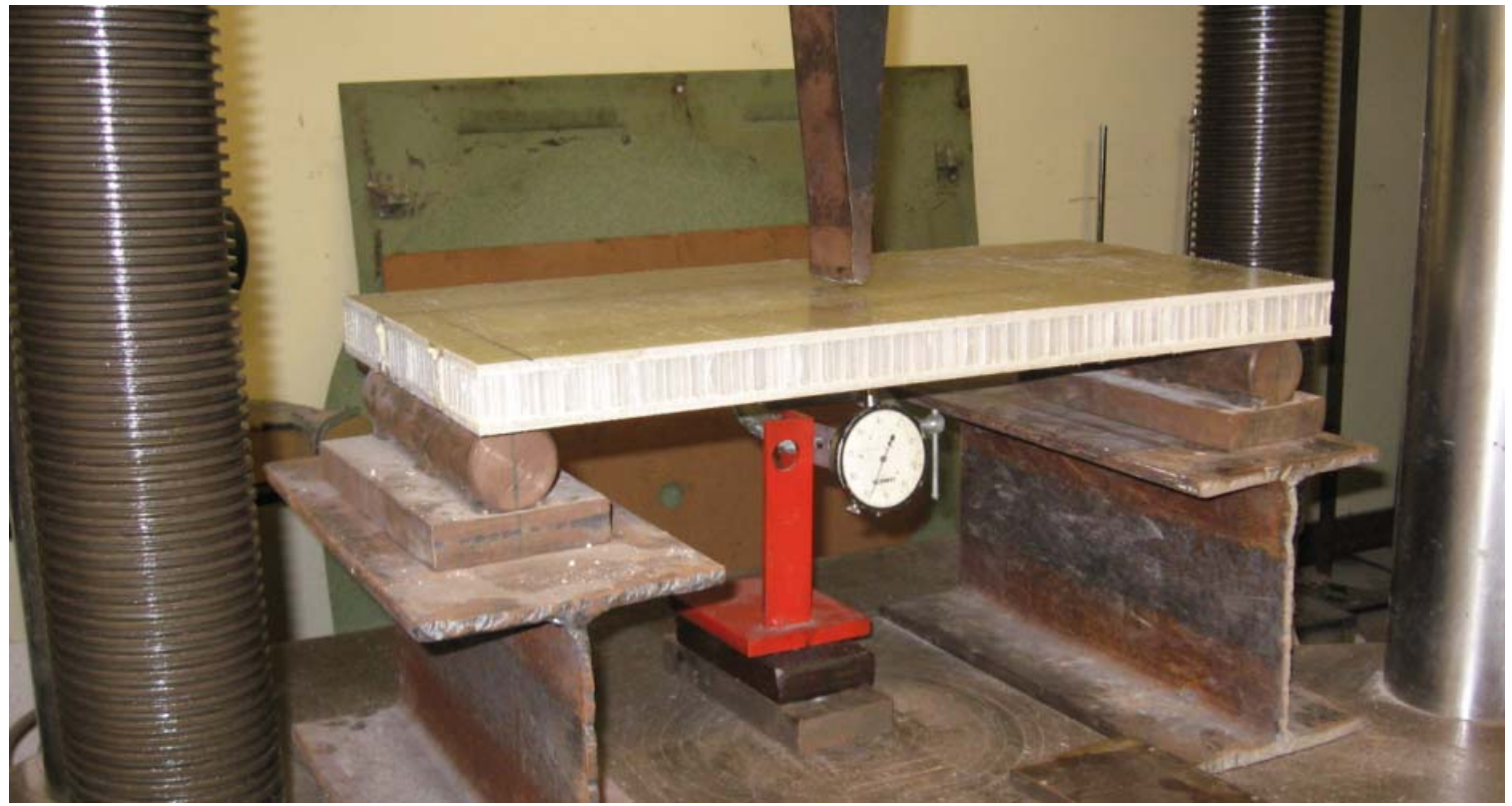

Figure B.4 Bending test of type III panel just before putting the patch 
Table B.3 Bending test results of type II and III honeycomb panel

\begin{tabular}{|l|l|l|l|l|l|l|l|}
\hline $\begin{array}{l}\text { Effective } \\
\text { Span } \\
\text { C-C } \\
\text { (inch) }\end{array}$ & $\begin{array}{l}\text { Width } \\
\text { (inch) }\end{array}$ & $\begin{array}{l}\text { Face } \\
\text { Thickness } \\
\text { (inch) }\end{array}$ & $\begin{array}{l}\text { Total } \\
\text { Depth } \\
\text { (inch) }\end{array}$ & $\begin{array}{l}\text { Moment } \\
\text { of } \\
\text { Inertia } \\
\text { (in }^{4} \text { ) }\end{array}$ & $\begin{array}{l}\text { Ultimate } \\
\text { Load } \\
\text { (lbs) }\end{array}$ & $\begin{array}{l}\text { Bending } \\
\text { Stress } \\
\text { (ksi) }\end{array}$ & $\begin{array}{l}\text { Bending } \\
\text { Modulus } \\
\text { (msi) }\end{array}$ \\
\hline 20.5 & 9.0 & 0.103 & 0.987 & 0.36 & 3600 & 27.60 & 2.14 \\
\hline 23.0 & 8.0 & 0.245 & 1.420 & 1.35 & 12000 & 36.29 & 2.38 \\
\hline
\end{tabular}

Figures B.5 and B.6 are the load-deflection curves of type II and type III panels.

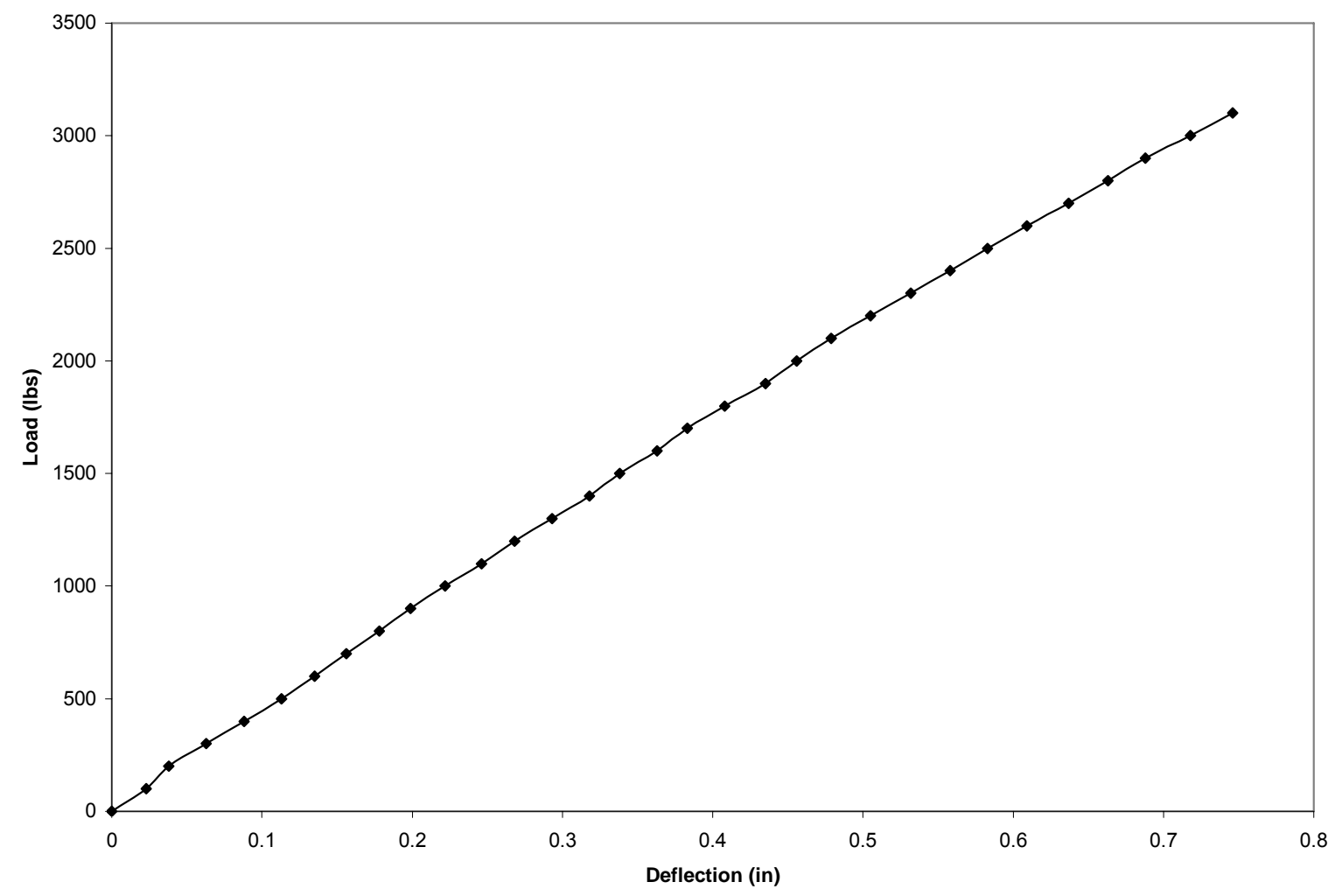

Figure B.5 Load Vs deflection Curve of type II panel 


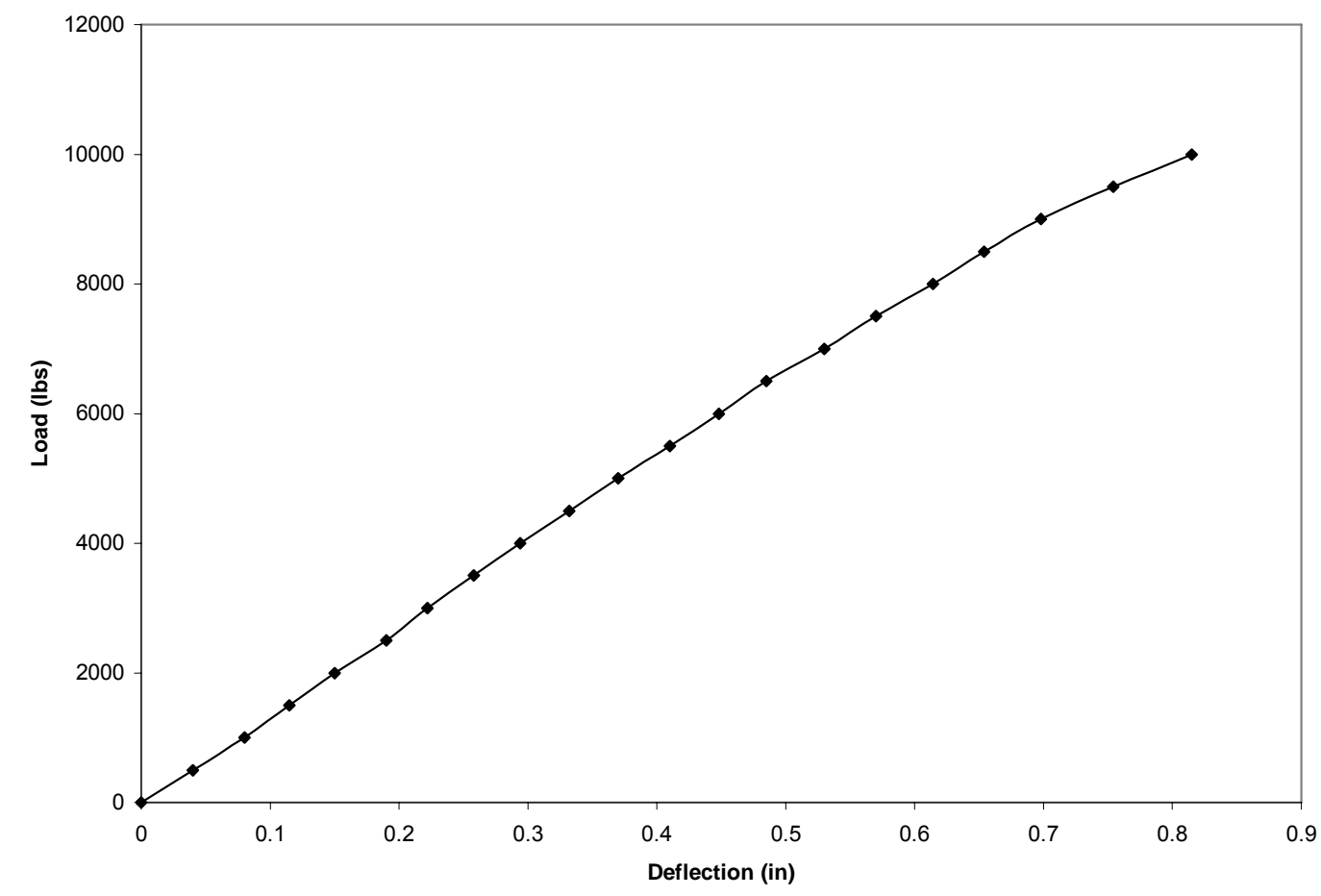

Figure B.6 Load Vs deflection Curve of type III panel

Figure B.7 shows the failure pattern of the honeycomb panel under three point patch loading.

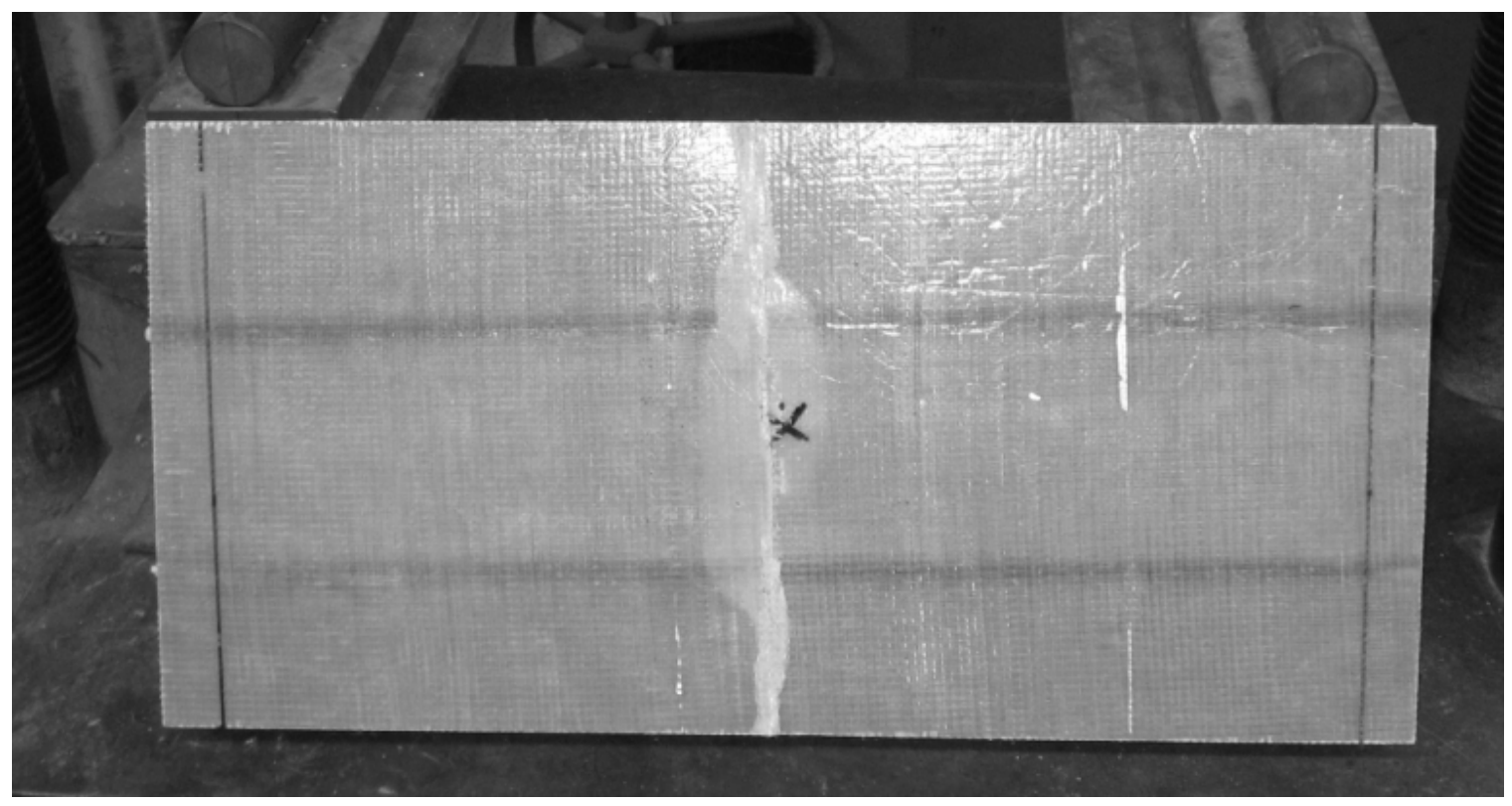

Figure B.7 Failure pattern of the honeycomb panel 


\section{APPENDIX C RECOMMENDED 3-D STITCHING TECHNIQUE FOR PANELS}

\section{C.1 Introduction}

Use of FRP composites in construction industry has been growing rapidly. However, currently all traditional composite shapes are manufactured with one and/or two dimensional fibers and fabrics (1-D or 2-D) which result in a weak shear plane between the fabric layers. Composites made of 1-D or 2-D fabrics have good mechanical properties in the plane of reinforcement. However, such composites possess low through-thickness strength and stiffness which primarily depend on resin bond. Also, a shortcoming of thick composite ( $~ 0.75$ in or higher) made of $1-D$ or $2-D$ fabrics is the reduction in strength, i.e., up to $50 \%$ of thin ( $\sim 0.5$ in or less) composites. This can be attributed to shear lag leading to ply-by-ply failure, in addition to potential premature failure of matrix and fabrics, or the interface failure i.e. lack of full transfer of in-plane force from one layer to another,, which is very common in thick composites.

In the current work, we have developed a novel three dimensionally (3-D) stitched pattern of fabrics for FRP composite modules, which can overcome the limitations of composites made of 1-D or 2-D fabrics, as described above. The main purpose of stitching is to attain better integrity for a structural shape where the fabrics run from top flange to bottom flange including interconnecting webs. Such stitching avoids inter laminar shear failure, delays local buckling failure and avoids catastrophic failure, which are predominant in 2-D composite shapes. We invented a unique three dimensionally stitched fabric skirting around all the cells of a FRP composite cellular panel, integrating all fabric layers in a manner to behave monolithically under any loading condition; thus avoiding delaminations of each fabric layer separately or local buckling of flange or web.

Through this disclosure, we are presenting our invention where, a 3-D stitched multi-cellular module with three dimensionally stitched fabrics has been developed and amenable for mass production. These modules have no size restrictions in terms of length, width and depth. A typical module used in the current work is shown in Figure C.1.

The multi-cellular module can be made with hollow core or any other solid or foam core. 


\section{C.2 The Stitch Pattern}

The details of the stitch pattern are described as below. We have elaborated the stitch pattern with the example of a multi-cellular rectangular shape module which was developed in CFCWVU research laboratory and this pattern can be extended to other closed-cell shapes such as pentagon or octagon. The fabric layers in the composite are named as part 1,2 and 3 corresponding to the fabrics used in the web, top flange and bottom flange respectively as shown in Figure C.1.

Step 1: Any traditional or commercially available fabric or any specially stitched fabric can be used to develop a 3-D stitched composite module.

Step 2: The fabrics are cut according to the dimensions needed to develop the module. For example, for the multi-cellular shape, four fabric of 25 " x 8 " size, are four in number are cut from commercially available fabrics which shall be used for part number 1 . Since the fabrics cannot be ended near the corners, additional fabric is required to make the module. Therefore, a fabric size of 25 " x 14 " shall be needed for part number $2 \& 3$.

Step 3: The locations of the stitches are marked on the fabrics and spacing is maintained at desired distance. The fabrics of part 1 are then integrated by the stitching at the marked location. For example, the location of stitch for part 1 that integrates the cells (web-to-web) is marked as shown in Figure C.2. The marking for stitching is done at every 0.5" or whatever might be the optimal stitch spacing and stitch type.

Part 1 of two adjacent cells are then stitched as shown in Figure C.3. Similarly, all the cells in part 1 are then stitched using the stitch pattern on the marked locations as shown in Figure C.4. Polyester or any other suitable thread can be used for the stitching. For example, we have established an optimum stitch density of (i.e, distance between two stitches) 0.5 " and the optimum pitch (i.e. the length of stitch) of $6 \mathrm{~mm}$ for 3-D stitched multi-cellular shape modules. The stitch density can vary depending on the part type, size and functionality.

Step 4: Once the fabrics of part 1 are stitched, part 2 shall be integrated with the top face of each cell. Before stitching, the marking of stitch locations should be performed. As for 
example, the marking for stitching is done at every 0.5 " on the part 2 fabrics. The whole module is rotated by 180 degrees as shown in the Figure C.5. Part 2 is then integrated with Part 1 , using a stitch density of 0.5 " and pitch of $6 \mathrm{~mm}$.

Step 5: Part 3 is then stitched to bottom face of each cell. It must be noted that stitching of the part 3 with part 1 must be done from cells 1 to $n$ as shown in the Figure C.6, where $n$ is the number of cells required in the width direction for making the part. For example, similar to part 2 , stitch locations are marked on part 3 at every 0.5 ".

Step 6: To get a hollow core, pneumatic bladders or hollow core made of steel or card board or any other retrievable material can be inserted before resin infusion to get proper dimensions of each cell core. All cells can be filled with any solid core if required.

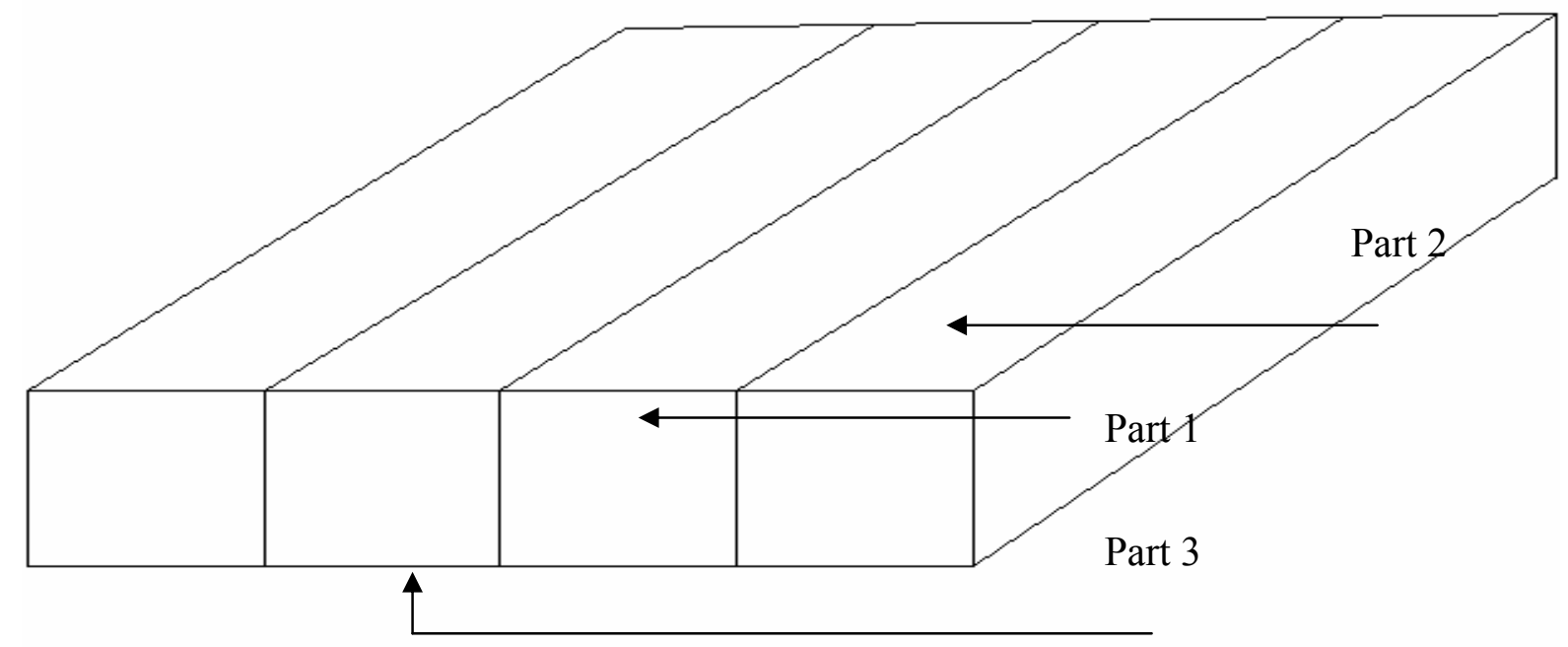

Figure C.1 Multi-cellular shape developed in the CFC research laboratory, at WVU 


\begin{tabular}{|c|c|c|c|c|}
\hline 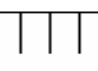 & 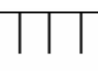 & 111 & 11 & \multirow{14}{*}{$\begin{array}{l}\text { Indicates the line along } \\
\text { which the stitching has to be } \\
\text { done }\end{array}$} \\
\hline | 11 & I I I & I I I & | I | & \\
\hline $11 \mid$ & $1 \mid 1$ & I I I & | I | & \\
\hline$|1|$ & $1 \mid 1$ & I I I & 111 & \\
\hline$|1|$ & $|1|$ & 111 & 41 & \\
\hline 111 & $1 \mid 1$ & 111 & $11 \mid$ & \\
\hline$|1|$ & || $\mid$ & I I I & $|1|$ & \\
\hline 111 & 111 & 111 & | I | & \\
\hline $11 \mid$ & 111 & 111 & $11 \mid$ & \\
\hline 111 & 111 & 111 & | 11 & \\
\hline $11 \mid$ & 111 & I I I & | I | & \\
\hline 111 & 111 & 111 & 111 & \\
\hline | I | & I I I & I I I & | I | & \\
\hline 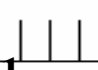 & $\perp$ & 11 & 11 & \\
\hline
\end{tabular}

Figure C.2 Part 1 fabric

(Part 1 fabric 1 on which stitching will be done along the marks indicated by dotted lines. It has four faces as the cells in this example are rectangular in cross section. Similarly fabrics for pat 2 and part 3 are marked according to the desired spacing. 


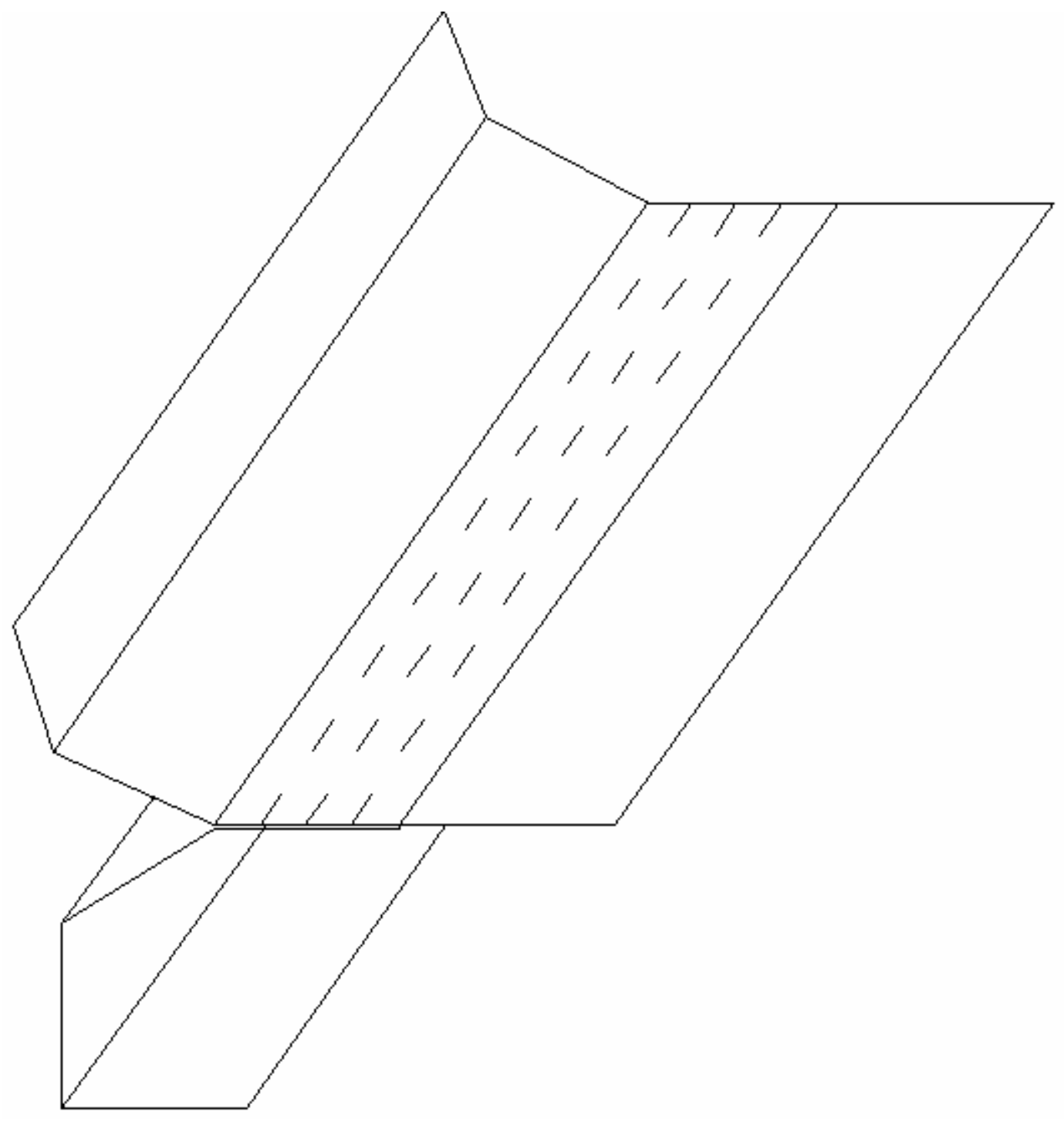

Figure C.3 The webs (part 1) of two adjacent cells

(Two adjacent webs are stitched. Similarly each of all cells is stitched at the web to its adjacent cell's web. 


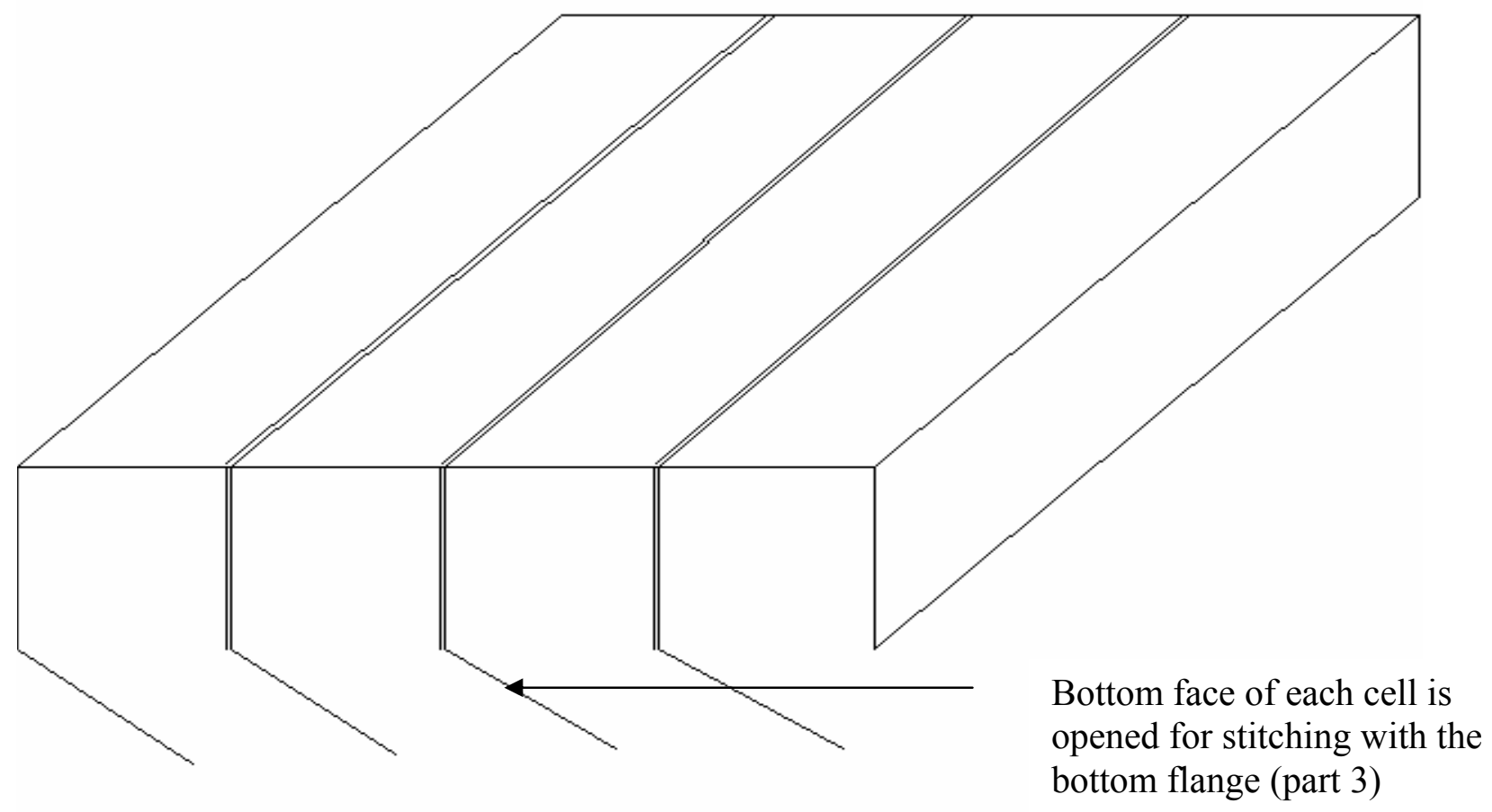

Figure C.4 After all webs (part 1) of all the cells are stitched to each other.

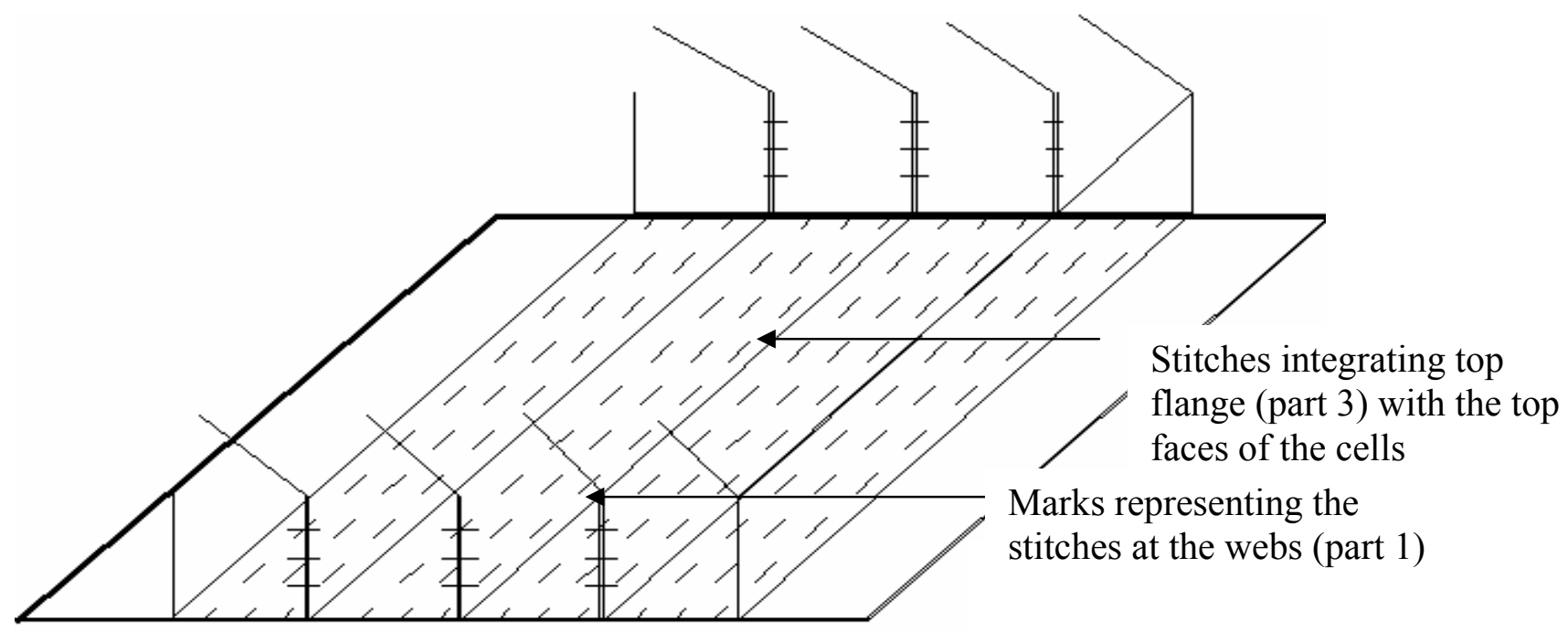

Figure C.5 Stitched cells are then rotated 180 degrees from position in figure 4. The top flange (part 2) is then stitched with the top face of each cell 

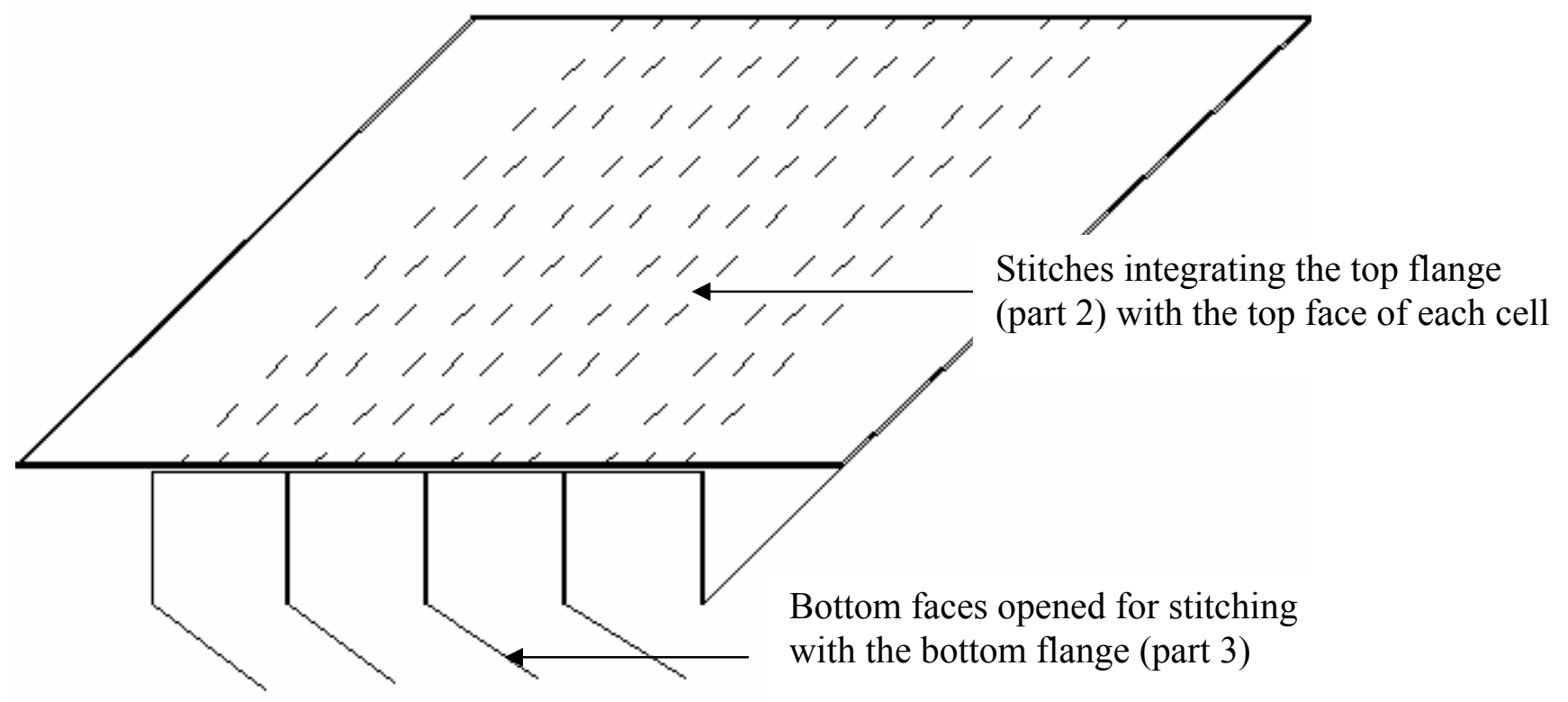

Figure C.6 The top flange (part 2) is stitched to the top face of each cell and then rotated to original position

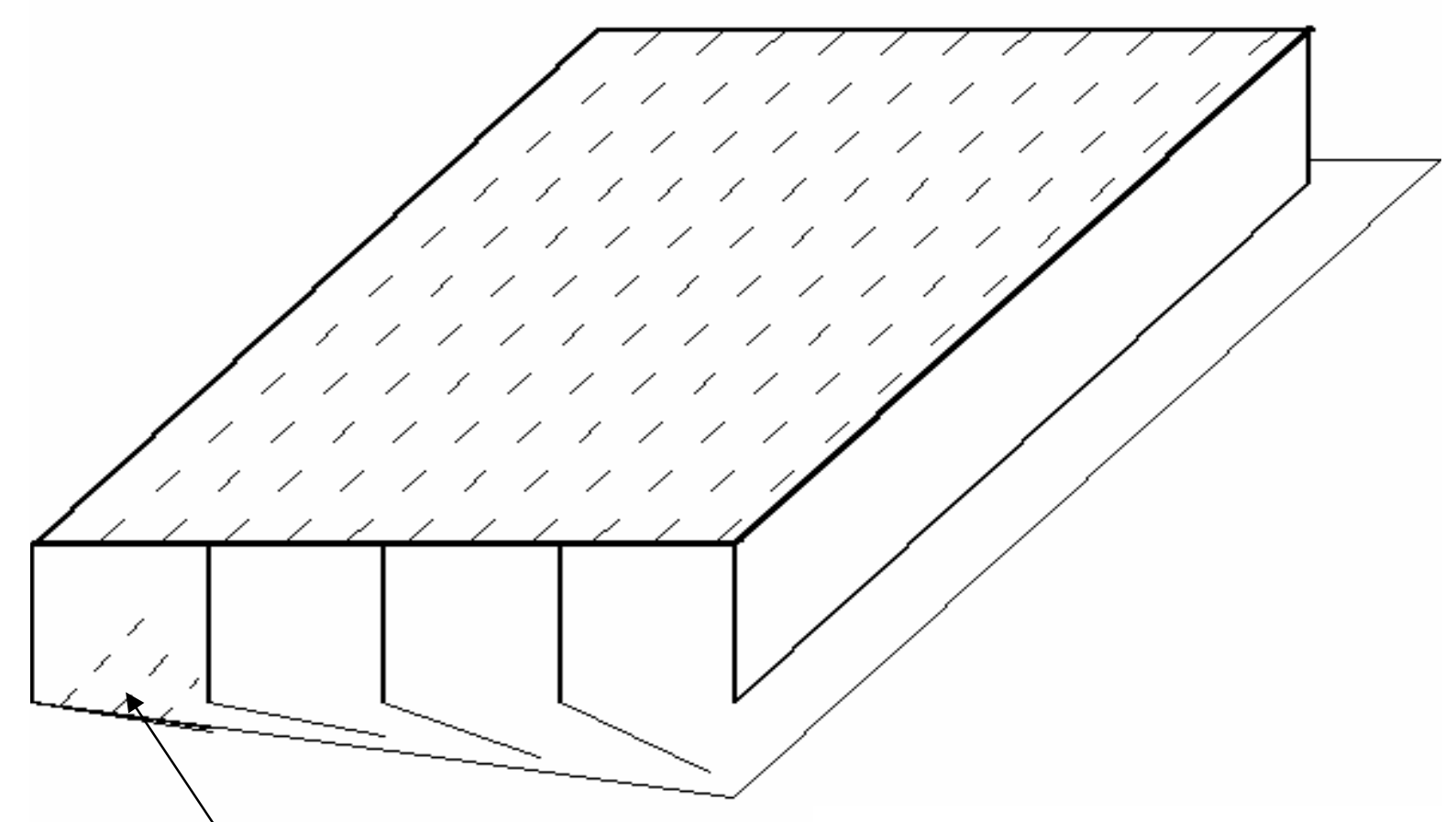

Stitches integrating the bottom flange (part 3) with the bottom face of the cell

Figure C.7 The bottom flange (part 3) is stitched to the bottom face of each cell. 


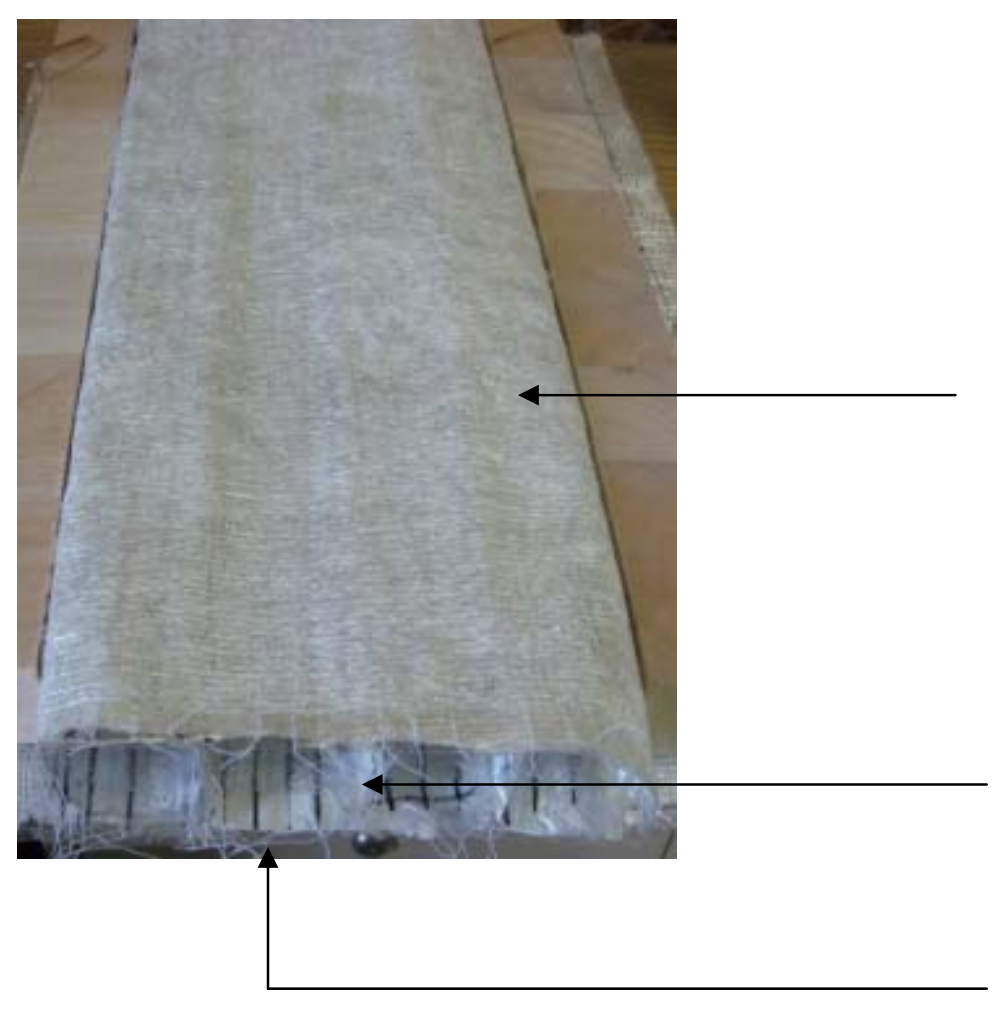

Part 2 (Top flange fabric)

Part 1 (Web fabrics)

Figure C.8 Multi-cellular shape developed in the research laboratory, CFC, WVU

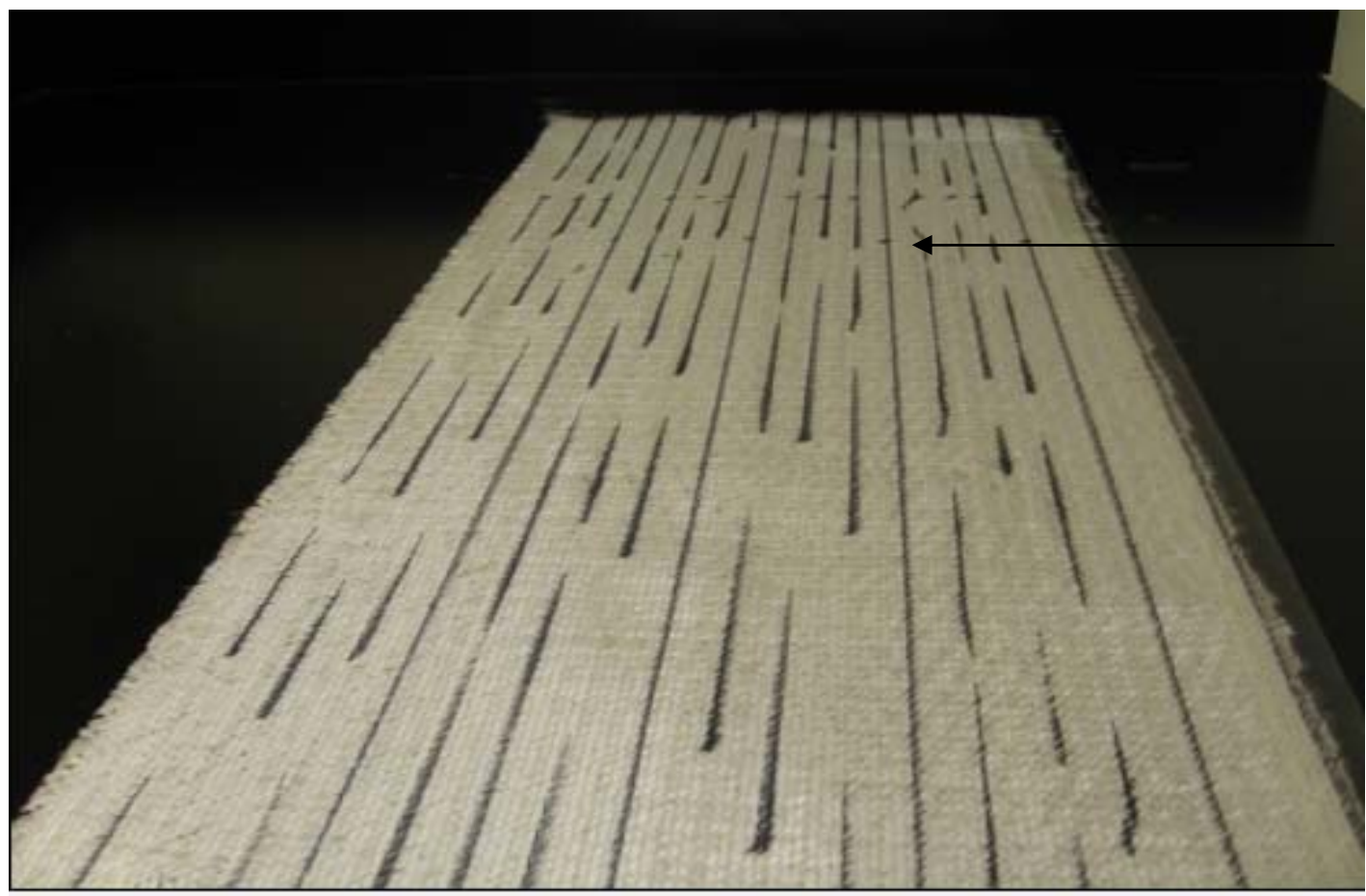

Stitch

marks

Figure C.9 The fabrics are marked at 0.5 ' spacing to fix the stitching locations 


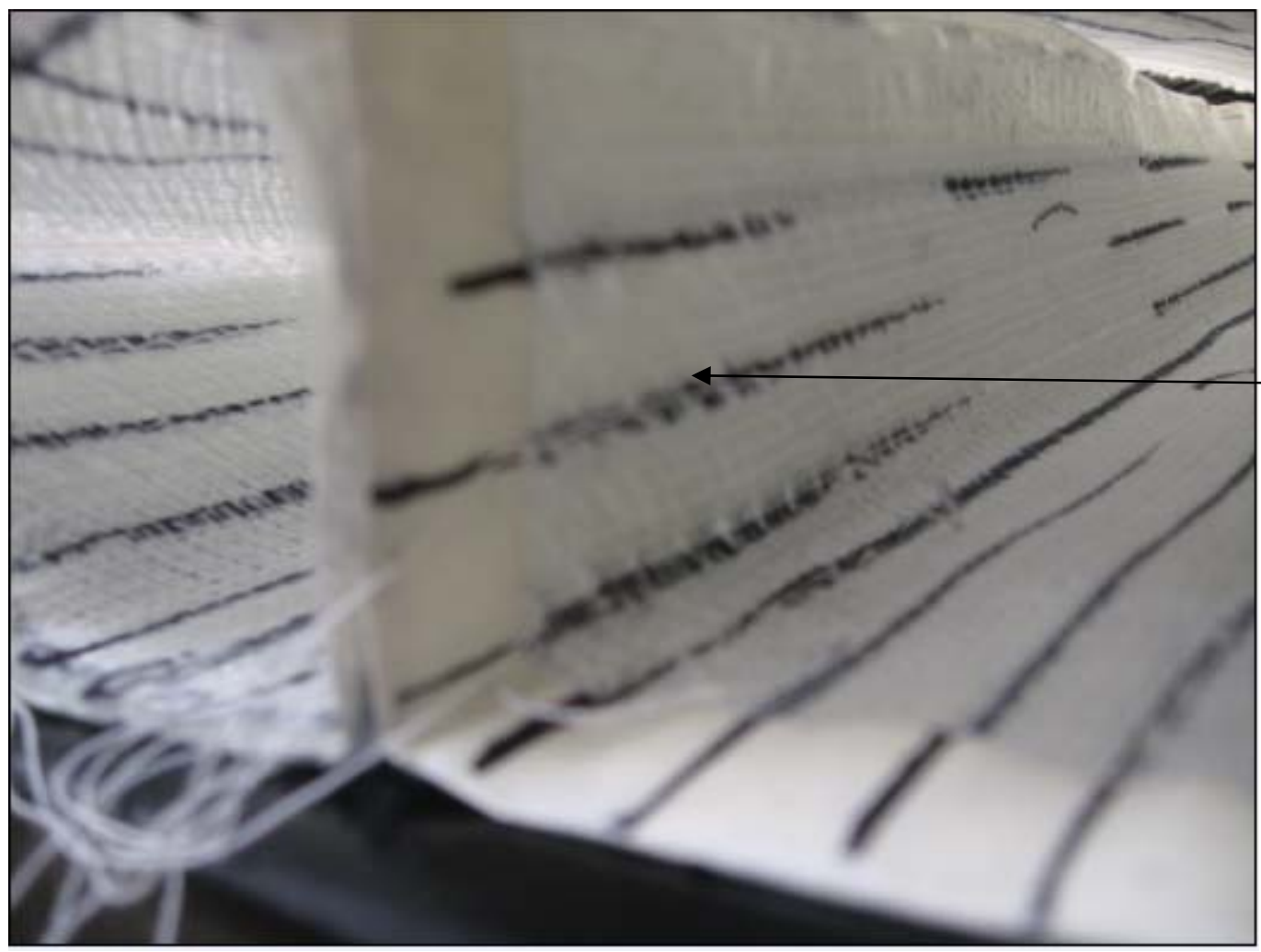

Part 1 stitched to part 1

Figure C.10 The part 1 (web) integrated with part 1(web) by stitching

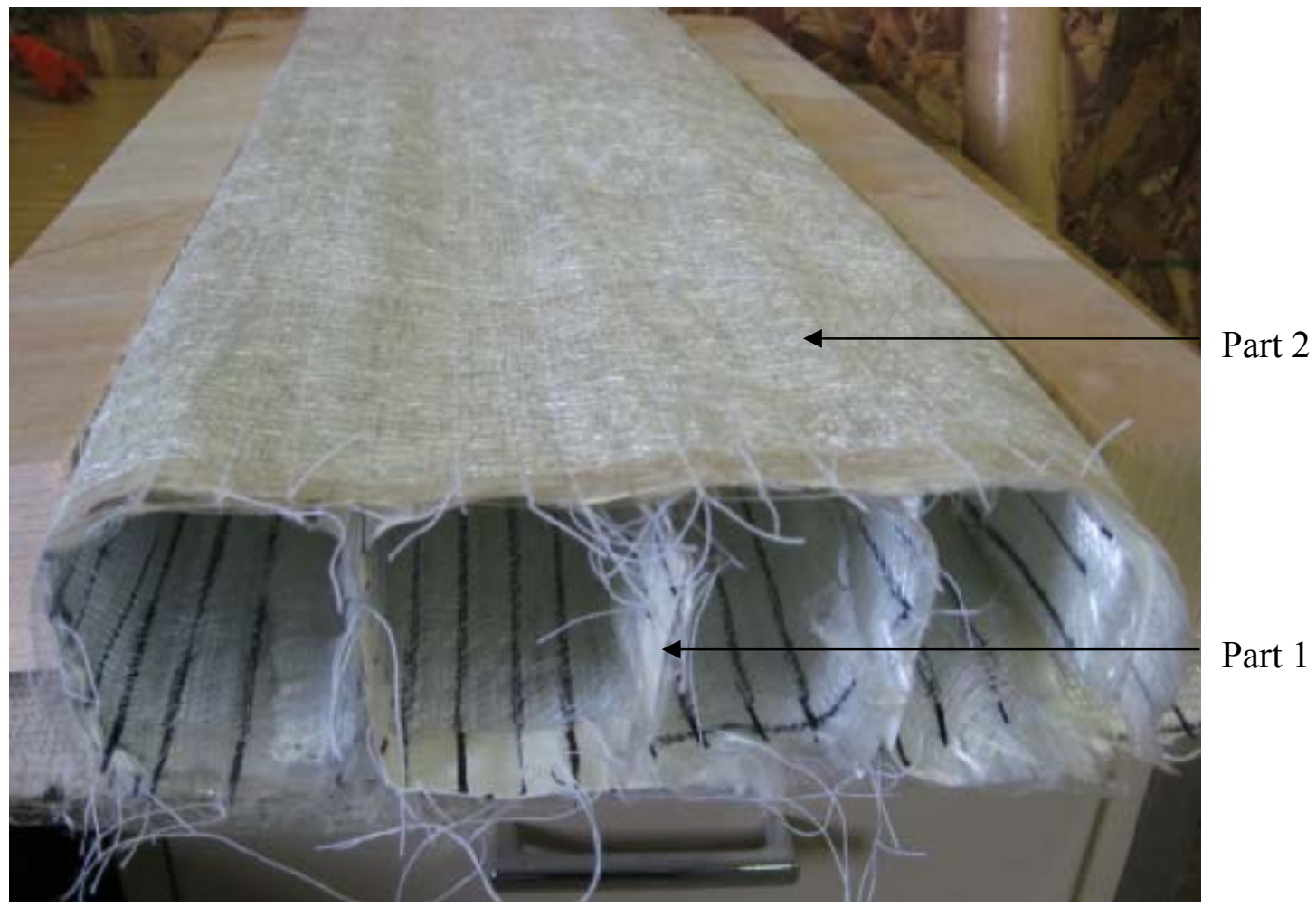

Figure C.11 The part 2 is integrated with part 1 


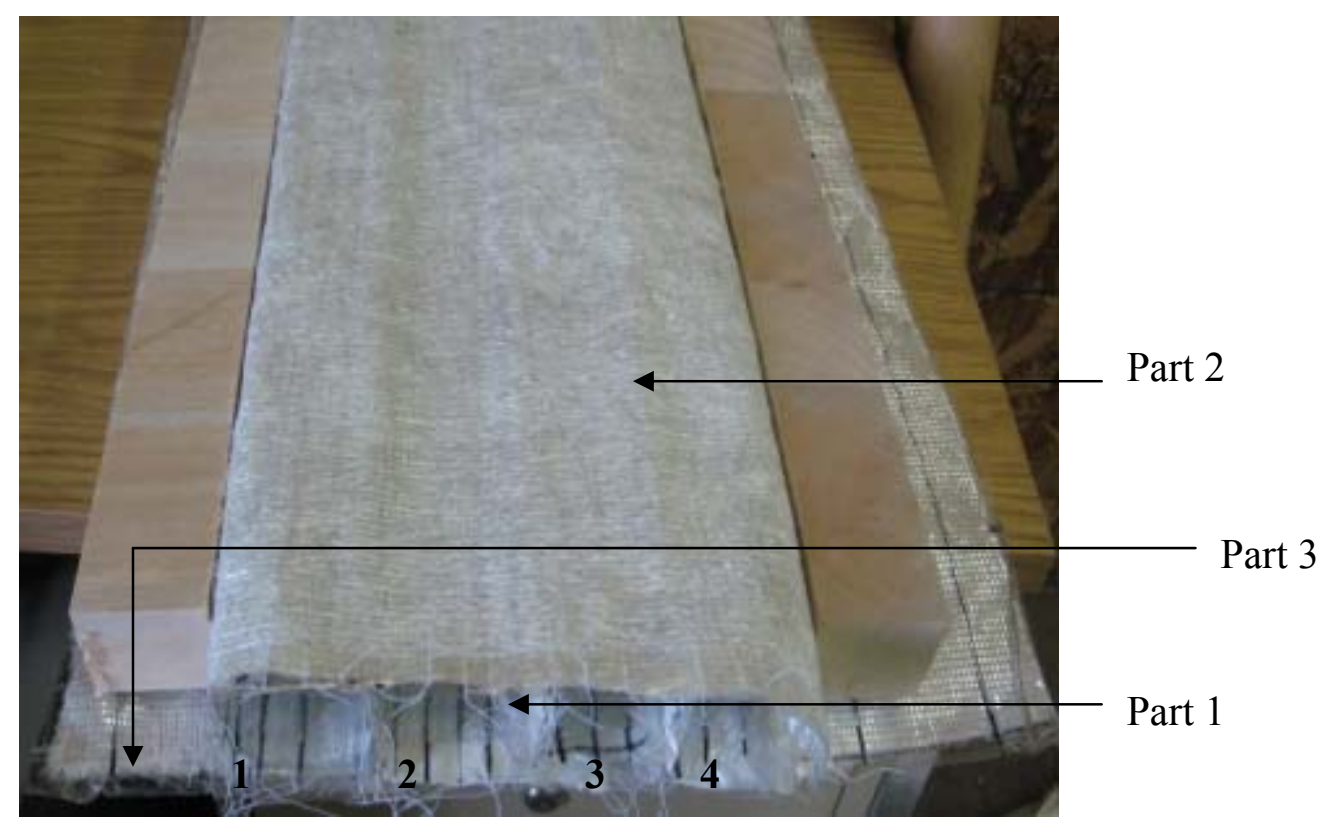

Figure C.12 The part 3 is integrated with part 1 


\section{APPENDIX D CLASSICAL LAMINAR PLATE THEORY AND ACTUAL CALCULATIONS}

\section{D.1 Classical Laminar Plate Theory (CLPT) for Design}

This section discusses the philosophy behind classical laminar plate theory and its implementation in the design of composite panels.

\section{D.1.1 Introduction to CLPT}

In this section, we used Working Stress Design methodology developed by CFC-WVU and discussed by Prof. GangaRao. In this design approach, safety is incorporated by considering factors to ultimate stresses of materials, i.e., arriving at allowable stresses, and making sure that those allowable stresses are greater than the induced stresses obtained from design loads of current building or bridge design code. These safety factors are introduced on ultimate (failure) strains of laminates. Stress level in a laminate is limited based on appropriate failure criterion. First ply failure criterion In this proposed design approach, knock-down factors are incorporated to account for any loss of strength or stiffness during service-life of FRP composite structural shapes. The knock down factors also account for aging, stress concentrations at re-entrant angles or holes, moisture effects, size effects, sustained stress etc in the design. For now (in the absence of extensive field data) this knock-down factor can be taken as 0.4 for FRP composite structural shapes (Karbhari, 1997).

Any design involves computing: (1) bending and shear rigidities (2) strengths of FRP composite shapes (3) buckling resistance of webs (4) interaction checks of axial, bending and shear stresses to establish allowable design stresses, and (5) limiting the load induced stresses and deformation within allowable values.

\section{D.1.2 Computation of Bending (EI) and Shear Rigidities (GA)}

Bending and shear rigidities are computed by Classical Lamination Theory (Jones, 1975). The in-plane stiffness matrix $[\mathrm{A}]$, bending-extension coupling stiffness matrix $[\mathrm{B}]$ etc are computed to predict the bending and shear rigidities of an FRP composite structural shape. The Classical Lamination theory is simplified and the modified version known as Approximate Classical Lamination Theory (Nagraj, 1994) is used in this section. The following are the steps involved in the computation: 


\section{STEP 1: COMPUTE THE MATERIAL PROPERTIES}

The material properties include Young's Modulus, shear modulus, and density of fibers/fabrics and matrix. The properties of fibers and matrix are usually acquired from material suppliers.

Modulus of elasticity of Fiber (psi) $=\mathrm{E}_{\mathrm{f}}$

Modulus of elasticity of Matrix (psi) $=\mathrm{E}_{\mathrm{m}}$

Shear modulus of Fiber $(\mathrm{psi})=\mathrm{G}_{\mathrm{f}}$

Shear modulus of Matrix (psi) $=\mathrm{G}_{\mathrm{m}}$

From the above properties, Poisson's ratio for fiber can be obtained as: (Jones, 1975).

Poisson's ratio of fiber: $v_{f}=\frac{E_{f}}{2 G_{f}}-1$

Poisson's ratio of matrix: $v_{m}=\frac{E_{m}}{2 G_{m}}-1$

\section{STEP 2: DETERMINATION OF COMPOSITE THICKNESS}

Depending on the manufacturing process, we can assume a thickness. For example, $40 \mathrm{oz} / \mathrm{yd}^{2}$ of fabric yields a thickness about 0.048 inches in resin infusion for Fiber Volume Fraction of $55 \%$. We can use an actual thickness if available on the basis of the pass experience. For prediction purposes of the actual product, we can use the measured thickness of the product.

\section{STEP 3: COMPUTATION OF FIBER VOLUME FRACTION:}

Based on the thickness and weight of the fabric of each ply in the composite part, fiber volume fraction is computed as follows:

$$
\mathrm{V}_{\mathrm{f}}=\frac{\mathrm{W}_{\mathrm{f}}}{\rho_{\mathrm{f}} \mathrm{L}_{\mathrm{v}}}
$$

Where,

$\mathrm{W}_{\mathrm{f}}=$ Weight of fabric $(\mathrm{lb})$

$\mathrm{L}_{\mathrm{v}}=$ Volume of 1' x 1' composite laminate $\left(\mathrm{in}^{3}\right)$

$\rho_{\mathrm{f}}=$ Density of fabric $\left(\mathrm{lb} / \mathrm{in}^{3}\right)$

We can also use the actual FVF evaluated by burn out test.

\section{STEP 4: EVALUATION OF LAMINA PROPERTIES}

\section{Fabrics:}

Rule of mixture is used for calculating $\mathrm{E}$ and $\mathrm{G}$. 
Elastic modulus, $\quad \mathrm{E}_{1}=\mathrm{E}_{\mathrm{f}} \mathrm{V}_{\mathrm{f}}+\mathrm{E}_{\mathrm{m}} \mathrm{V}_{\mathrm{m}}$

where, $E_{f}=$ Young's modulus of glass fiber

$E_{m}=$ Young's modulus of resin

$\mathrm{V}_{\mathrm{f}}=$ Fiber volume fraction

$\mathrm{V}_{\mathrm{m}}=1-\mathrm{V}_{\mathrm{f}}=$ Matrix volume fraction

$$
E_{2}=\frac{E_{f} E_{m}}{V_{f} E_{m}+V_{m} E_{f}}
$$

Shear modulus, $\quad G_{12}=\frac{G_{f} G_{m}}{V_{f} G_{m}+V_{m} G_{f}}$

\section{Continuous strand mat:}

Elastic modulus, $\quad \mathrm{E}_{\mathrm{ran}}=\frac{3}{8} E_{1}+\frac{5}{8} E_{2}$

Shear modulus, $\quad \mathrm{G}_{\mathrm{ran}}=\frac{1}{8} E_{1}+\frac{1}{4} E_{2}$

STEP 5: COMPUTATION OF IN-PLANE STIFFNESS [A] FOR THE FLANGES:

$$
A_{f}=b \times \sum_{r=1}^{n} E_{r} t_{r}
$$

where $E_{r}=E_{1} \operatorname{Cos}^{4} \theta$

$\mathrm{t}_{\mathrm{r}}=$ thickness of each lamina

$\theta=$ angle of orientation

STEP 6: COMPUTATION OF BENDING-STIFFNESS [D] FOR THE WEB

$\mathrm{D}=N \times\left(\frac{d^{3}}{12}\right) \sum_{r=1}^{n} E_{r} t_{r}, \mathrm{~N}=$ total number of webs

STEP 7: COMPUTATION OF GLOBAL BENDING STIFFNESS EI

$$
\mathrm{EI}=\mathrm{D}_{\text {web }}+\mathrm{A}_{\text {flange }}\left(\mathrm{e}_{\mathrm{o}}\right)^{2}
$$

where, $\quad \mathrm{e}_{\mathrm{o}}=$ distance between neutral axis and cg of top flange

STEP 8: COMPUTATION OF GLOBAL SHEAR STIFFNESS:

$$
G A=d \times \sum_{r=1}^{n} G_{r} t_{r}
$$

where, 


$$
G_{r}=E_{1} \sin ^{2} \theta \cos ^{2} \theta+G_{12}\left(\sin ^{2} \theta-\cos ^{2} \theta\right)^{2}
$$

\section{D.1.3 Actual Calculation Done for our Panel System}

The above design steps were used in order to calculate the bending and shear moduli of the panels manufactured for installing as a roadway pavement. The theoretical bending modulus and shear modulus were obtained as $2.93 \mathrm{msi}$ and $0.504 \mathrm{msi}$, respectively. Average fiber volume fraction at the flanges and webs were taken as $50 \%$ and $33 \%$, respectively. The shear modulus value obtained theoretically was used to calculate the shear deflection and shear deflection was neglected from the experimentally measured deflection to obtain deflection of the panel under pure bending. This deflection due to only bending was used to calculate the bending modulus of the panel.

\section{Step 1:}

$\begin{array}{llll}\text { Ef } & \text { (psi) } & = & 9.000 \mathrm{E}+06 \\ \text { Em } & \text { (psi) } & = & 3.000 \mathrm{E}+05 \\ \text { Gf } & \text { (psi) } & = & 4.180 \mathrm{E}+06 \\ \text { Gm } & \text { (psi) } & = & 2.300 \mathrm{E}+05 \\ & & & \\ \text { vf } & & 0.076555024 \\ \text { vm } & & -0.347826087\end{array}$

\section{Step 2:}

Thickness of Flange (in) $\quad 0.307$

Thickness of Web (in) $\quad 0.335$

\section{Step 3:}

(A) $16.4 \mathrm{Oz} / \mathrm{yd} 2 \mathrm{0} / 90$ fabric

Fiber Volume Fraction

Matrix Volume Fraction (in flange )

0.5

0.5

$$
\begin{array}{lll}
\mathrm{E}_{1} & 4.65 \mathrm{E}+06 & \text { psi } \\
\mathrm{E}_{2} & 5.81 \mathrm{E}+05 & \text { psi } \\
\mathrm{G}_{12} & 4.36 \mathrm{E}+05 & \text { psi }
\end{array}
$$


(B) $24 \mathrm{oz} / \mathrm{yd} 2+45 /-45$ fabric

Fiber Volume Fraction

Matrix Volume Fraction

$\mathrm{E}_{1} \quad 4.65 \mathrm{E}+06 \mathrm{psi}$

$\mathrm{E}_{2} \quad 5.81 \mathrm{E}+05$ psi

$\mathrm{G}_{12} \quad 4.36 \mathrm{E}+05$ psi

(C) $16.4 \mathrm{oz} / \mathrm{yd} 2-45 / 45$ fabric

Fiber Volume Fraction

Matrix Volume Fraction

$\mathrm{E}_{1} \quad 4.65 \mathrm{E}+06 \mathrm{psi}$

$\mathrm{E}_{2} \quad 5.81 \mathrm{E}+05 \mathrm{psi}$

$\mathrm{G}_{12} \quad 4.36 \mathrm{E}+05 \mathrm{psi}$

(D) $16.4 \mathrm{oz} / \mathrm{yd} 20 / 90$ fabric

Fiber Volume Fraction

Matrix Volume Fraction

$\mathrm{E}_{1} \quad 3.17 \mathrm{E}+06 \mathrm{psi}$

$\mathrm{E}_{2} \quad 4.41 \mathrm{E}+05 \mathrm{psi}$

$\mathrm{G}_{12} \quad 3.34 \mathrm{E}+05$ psi

(E) $16.4 \mathrm{oz} / \mathrm{yd} 2-45 / 45$ fabric

Fiber Volume Fraction

Matrix Volume Fraction

$\mathrm{E}_{1} \quad 3.17 \mathrm{E}+06$ psi

$\mathrm{E}_{2} \quad 4.41 \mathrm{E}+05 \mathrm{psi}$

$\mathrm{G}_{12} \quad 3.34 \mathrm{E}+05$ psi (in flange )

0.5

0.5

(in flange )

0.5

0.5

(in web)

0.33

0.67

(in web)

0.33

0.67 
Step 4:Extensional Stiffness Matrix for flange

\begin{tabular}{|c|c|c|c|c|c|c|}
\hline Material & $\begin{array}{c}\text { Number } \\
\text { of Layers }\end{array}$ & $\begin{array}{c}\mathbf{E}_{\mathbf{1}} \\
(\mathbf{p s i})\end{array}$ & $\begin{array}{c}\text { Theta } \\
\text { (degree) }\end{array}$ & $\begin{array}{c}\mathbf{E}_{\mathbf{r}} \\
(\mathbf{p s i})\end{array}$ & $\begin{array}{c}\mathbf{t}_{\mathbf{r}} \\
(\mathbf{i n})\end{array}$ & $\begin{array}{c}\mathbf{E}_{\mathbf{r}} \cdot \mathbf{t}_{\mathbf{r}} \\
(\mathbf{p s i} . \text { in) }\end{array}$ \\
\hline $16.4 \mathrm{oz} \mathrm{0/90}$ & 11 & $4.65 \mathrm{E}+06$ & 0 & $4.65 \mathrm{E}+06$ & 0.218 & $1.01 \mathrm{E}+06$ \\
\hline $16.4 \mathrm{oz} \mathrm{0/90}$ & 3 & $4.65 \mathrm{E}+06$ & 45 & $1.16 \mathrm{E}+06$ & 0.061 & $7.09 \mathrm{E}+04$ \\
\hline $24 \mathrm{oz}-45 / 45$ & 1 & $4.65 \mathrm{E}+06$ & 45 & $1.16 \mathrm{E}+06$ & 0.028 & $3.26 \mathrm{E}+04$ \\
\hline
\end{tabular}

$$
\Sigma \mathrm{t}_{\mathrm{r}}=0.307 \quad \Sigma \mathrm{E}_{\mathrm{r}} \cdot \mathrm{t}_{\mathrm{r}}=1.12 \mathrm{E}+06
$$

Width of flange (in): 130

$\mathrm{A}_{\mathrm{f}} \quad 1.45 \mathrm{E}+08 \quad$ psi.in $^{2}$

Step 5: $\quad$ Bending stiffness matrix for web

\begin{tabular}{|l|l|l|l|l|l|l|l|l|l|}
\hline Material & $\begin{array}{l}\text { Num. } \\
\mathbf{o f} \\
\text { Layers }\end{array}$ & $\begin{array}{l}\mathbf{E}_{\mathbf{1}} \\
(\mathbf{p s i})\end{array}$ & $\begin{array}{l}\mathbf{G}_{\mathbf{1 2}} \\
\mathbf{( p s i )}\end{array}$ & $\begin{array}{l}\text { thet. } \\
\mathbf{( d e g . )}\end{array}$ & $\begin{array}{l}\mathbf{E}_{\mathbf{r}} \\
(\mathbf{p s i})\end{array}$ & $\begin{array}{l}\mathbf{G}_{\mathbf{x}} \\
(\mathbf{p s})\end{array}$ & $\begin{array}{l}\mathbf{t}_{\mathbf{r}} \\
(\mathbf{i n})\end{array}$ & $\begin{array}{l}\mathbf{E}_{\mathbf{r}} * \mathbf{t} \\
(\mathbf{p s i . i n})\end{array}$ & $\begin{array}{l}\mathbf{G}_{\mathbf{r}} * \mathbf{t}_{\mathbf{r}} \\
(\mathbf{p s i} . \mathbf{i n})\end{array}$ \\
\hline $\begin{array}{l}16.4 \mathrm{oz} \\
0 / 90\end{array}$ & 10 & $3.17 \mathrm{E}+06$ & $3.34 \mathrm{E}+05$ & 0 & $3.17 \mathrm{E}+06$ & $3.34 \mathrm{E}+05$ & 0.191 & $6.06 \mathrm{E}+05$ & $6.38 \mathrm{E}+04$ \\
\hline $\begin{array}{l}16.4 \mathrm{oz} \\
-45 / 45\end{array}$ & 6 & $3.17 \mathrm{E}+06$ & $3.34 \mathrm{E}+05$ & 45 & $7.93 \mathrm{E}+05$ & $7.93 \mathrm{E}+05$ & 0.144 & $1.14 \mathrm{E}+05$ & $1.14 \mathrm{E}+05$ \\
\hline
\end{tabular}

$$
\Sigma \mathrm{t}_{\mathrm{r}}=0.335 \quad \Sigma \mathrm{E}_{\mathrm{r}} \cdot \mathrm{t}_{\mathrm{r}}=7.2 \mathrm{E}+05 \quad \Sigma \mathrm{G}_{\mathrm{r}} \cdot \mathrm{t}_{\mathrm{r}}=1.78 \mathrm{E}+05
$$

Depth of the web (in) 2.834

$\mathrm{D}_{\mathrm{w}}$ for one web: $\quad 1.37 \mathrm{E}+06 \mathrm{psi}^{\mathrm{in}}{ }^{4}$

Total Number of webs: 21

Therefore, $\mathrm{D}_{\mathrm{w}}$ for 21 webs: $\quad 2.87 \mathrm{E}+07$ psi.in ${ }^{4}$

Step 6: Modulus values:

$\mathrm{e}_{0} \quad 1.2635 \quad$ in 

EI $\quad 4.92 \mathrm{E}+08 \quad$ psi.in $^{4}$
I $\quad 168$ in $^{4}$
E $\quad 2.93 \mathrm{E}+06 \quad$ psi
GA $\quad 5.04 \mathrm{E}+05 \quad$ psi.in ${ }^{2}$

\section{D.1.4 Sample Calculation for Deflection Correction due to Shear}

Total deflection of the panel at the center under three point bending $=\mathrm{PL}^{3} /(48 \mathrm{EI})+$

$\mathrm{PL} /$ (4GA). Deflection due to only bending could be calculated as = (Measured deflection)$\mathrm{PL} /(4 \mathrm{GA})$,

where GA was calculated theoretically as $=5.04 \mathrm{E}+05$ psi.in ${ }^{2}$

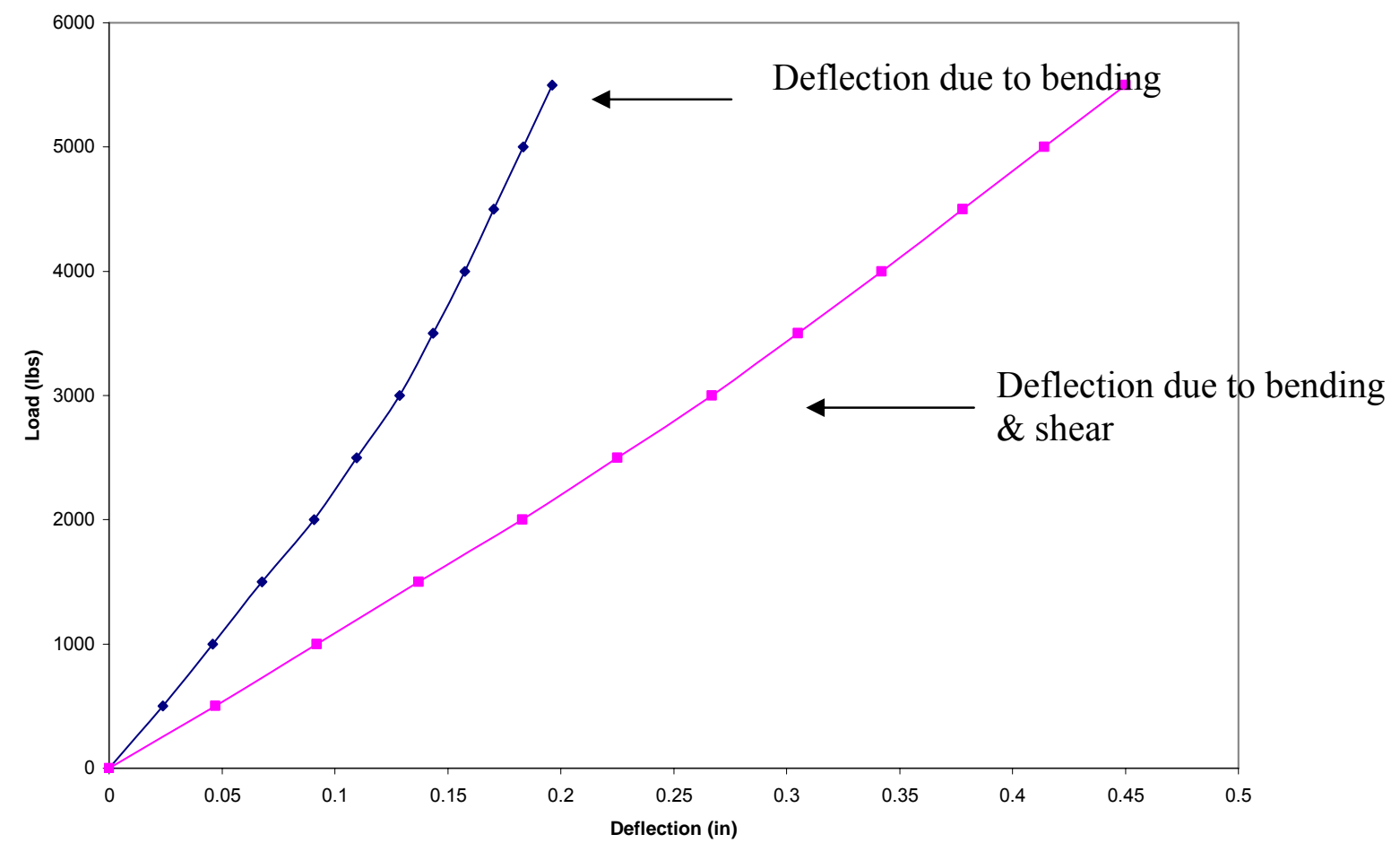

Figure D.1 Load Vs deflection curve shown as sample calculation 